\title{
EXPLORAÇÃO DE INFRAESTRUTURA FERROVIÁRIA: LIÇÕES DE EXTREMOS PARA O BRASIL
}

\section{MARCOS KLEBER RIBEIRO FELIX}

ORIENTADOR: REINALDO CRISPINIANO GARCIA

DISSERTAÇÃO DE MESTRADO EM TRANSPORTES

PUBLICAÇÃO: T. DM - 001/2018

BRASÍLIA/DF: 11 DE JANEIRO DE 2018 
UNIVERSIDADE DE BRASÍLIA

FACULDADE DE TECNOLOGIA

DEPARTAMENTO DE ENGENHARIA CIVIL E AMBIENTAL

\section{EXPLORAÇÃO DE INFRAESTRUTURA FERROVIÁRIA: LIÇÕES DE EXTREMOS PARA O BRASIL}

\section{MARCOS KLEBER RIBEIRO FELIX}

DISSERTAÇÃO SUBMETIDA AO PROGRAMA DE PÓS-GRADUAÇÃO EM TRANSPORTES DO DEPARTAMENTO DE ENGENHARIA CIVIL E AMBIENTAL DA UNIVERSIDADE DE BRASÍLIA COMO PARTE DOS REQUISÍTOS NECESSÁRIOS PARA A OBTENÇÃo DO GRAU DE MESTRE EM TRANSPORTES.

APROVADA POR:

REINALDO CRISPINIANO GARCIA, PhD (Universidade de Califórnia) (ORIENTADOR)

JOSÉ MATSUO SHIMOISHI, PhD (Universidade de Tóquio) (EXAMINADOR INTERNO)

JOÃO MELLO DA SILVA, PhD (Case Western Reserve University) (EXAMINADOR EXTERNO)

BRASÍLIA/DF, 11 de janeiro de 2018. 


\section{FELIX, MARCOS KLEBER RIBEIRO}

Exploração de infraestrutura ferroviária: lições de extremos para o Brasil [Distrito Federal] 2018. xiv, 162p., 210 x 297 mm (ENC/FT/UnB, Mestre, Transportes, 2018).

Dissertação de Mestrado - Universidade de Brasília. Faculdade de Tecnologia.

Departamento de Engenharia Civil e Ambiental.

1. Transporte Ferroviário

2. Regulação do Setor Ferroviário

$\mathrm{I}-\mathrm{ENC} / \mathrm{FT} / \mathrm{UnB}$
2. Modelos de Exploração Ferroviária

4. Benchmarking Ferroviário

II - Título (série)

\section{REFERÊNCIA BIBLIOGRÁFICA}

FELIX, M. K. R. (2018). Exploração de infraestrutura ferroviária: lições de extremos para o Brasil, Publicação T.DM - 001/2018, Departamento de Engenharia Civil e Ambiental, Universidade de Brasília, Brasília, DF, 162p.

\section{CESSÃO DE DIREITOS}

AUTOR: Marcos Kleber Ribeiro Felix

TÍTULO DA DISSERTAÇÃO DE MESTRADO: Exploração de infraestrutura ferroviária: lições de extremos para o Brasil.

GRAU/ANO: Mestre/2018.

É concedida à Universidade de Brasília permissão para reproduzir cópias desta dissertação de mestrado e para emprestar ou vender tais cópias somente para propósitos acadêmicos e científicos. O autor reserva outros direitos de publicação e nenhuma parte desta dissertação de mestrado pode ser reproduzida sem a autorização por escrito do autor.

Marco Kleber Ribeiro Felix

felix.mkrf@gmail.com

Rua 28-Norte, lote 4, apt. 1004-I, Águas Claras

71917-720 Brasília - DF - Brasil. 


\section{DEDICATÓRIA}

Às minhas queridas, Maria Laura, Fernanda Teresa, Margarida e Dona Tereza. 


\section{AGRADECIMENTOS}

Agradeço, inicialmente, à minha inteira família, que me apoiou e suportou nos momentos mais difíceis.

Ao Professor Carlos Henrique Marques da Rocha, o primeiro incentivador desta pesquisa. À Professora Geovana Lorena Bertussi, por suas sugestões e críticas. À Professora Michelle Andrade, por seu apoio e colaboração. Ao Professor Reinaldo Crispiniano Garcia, que me guiou neste trabalho. Aos demais Professores da banca examinadora pelas críticas, sem as quais este estudo não poderia ter sido realizado. Ao Professor Alan Ricardo da Silva, por seus ensinamentos estatísticos.

Aos colegas de turma do Programa de Pós-Graduação em Transportes - PPGT/UnB, aos demais professores, mestres e doutores, que ao longo dessa caminhada, dos créditos das disciplinas, dos seminários e do trabalho final, contribuíram e deram valor a este estudo.

À Camila Lucena, Assistente em Administração do PPGT/UnB, sempre prestativa e disponível para a solução de todas as dúvidas administrativas.

À Carlos Fernando do Nascimento por suas críticas, correções e ponderações sobre o instrumento da pesquisa, à Tarcísio Gomes de Freitas pelas críticas e sugestões acerca da amostragem de ferrovias estudadas. Não posso deixar de agradecer também aos colegas Bruno Salgado Lima, Alan de Oliveira Lopes e Daniel Matos Caldeira pelo incentivo e colaboração na divulgação da pesquisa junto aos atores interessados.

Aos meus colegas de trabalho, que muito contribuíram com suas opiniões e sugestões, principalmente meus amigos Clay Teles e Túlio Leal.

À Biblioteca do Senado e ao Núcleo de Estudos e Pesquisas da Consultoria Legislativa pelo suporte. E, finalmente, agradeço a todos os atores interessados que anonimamente contribuíram com esta pesquisa. 


\section{RESUMO}

A extensão, a densidade e a qualidade do modo ferroviário de transportes no Brasil são incompatíveis com o tamanho de sua economia no cenário mundial. As iniciativas governamentais para ampliar a infraestrutura ferroviária brasileira na última década não alcançaram os resultados esperados. Esta pesquisa procura avaliar o setor ferroviário brasileiro à luz de uma comparação internacional com benchmarks globais, como Reino Unido, Estados Unidos e China, a fim de identificar e propor a incorporação das melhores estratégias adotadas entre os países analisados. Além disso, avalia a percepção dos stakeholders brasileiros a novas maneiras de exploração do mercado ferroviário. $\mathrm{O}$ trabalho procura comprovar a hipótese de que ferrovias devem ser exploradas e reguladas, diferentemente, em função de suas características intrínsecas. A aplicação desse princípio permitiria, inclusive, a existência de um mercado de exploração integralmente privado, atualmente, inexistente no Brasil. A pesquisa encontrou evidências internacionais de que diversas formas de exploração da infraestrutura ferroviária são eficazes em termos de qualidade, extensão e densidade. Contudo, em termos de eficiência - execução de gastos públicos -, a exploração privada com integração vertical e competição por rotas é a mais recomenda para o Brasil, devido a seu déficit fiscal e de infraestrutura ferroviária. O estudo recomenda a desregulamentação e a reprivatização da malha ferroviária brasileira.

Palavras-chave: Transporte Ferroviário; Modelos de Exploração Ferroviária; Regulação do Setor Ferroviário; Benchmarking Ferroviário. 


\begin{abstract}
Extension, density, and quality of the rail transportation mode in Brazil are incompatible with the size of its economy on the world stage. Government initiatives to expand Brazilian rail infrastructure in the last decade have not achieved the expected results. This research tries to evaluate the Brazilian rail sector in the light of an international comparison with global benchmarks, such as England, the United States and China, in order to identify and propose the incorporation of the best strategies adopted among the analyzed countries. In addition, it assesses the perception of Brazilian stakeholders to new ways of exploring the rail market. The paper tries to prove the hypothesis that railways should be explored and regulated, differently, depending on the degree of competitiveness they have. The application of this principle would even allow the existence of an entirely private market of exploitation, currently lacking in Brazil. The research has found international evidence that various forms of exploration of railway infrastructure are effective in terms of quality, length and density. However, in terms of efficiency - execution of public spending, private operation with vertical integration and competition for routes is the most recommended for Brazil, due to its railway infrastructure and fiscal deficit. The study recommends the deregulation and reprivatization of the Brazilian rail network.
\end{abstract}

Keywords: Rail transport; Models of Railway Exploration; Regulation of the Railway Sector; Railroad Benchmarking. 


\section{SUMÁRIO}

\section{Capítulo}

1. INTRODUÇÃO

Página

1.1 APRESENTAÇÃO

1.2 FORMULAÇ̃̃A DO PROBLEMA

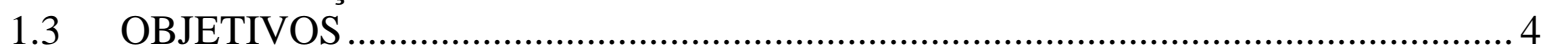

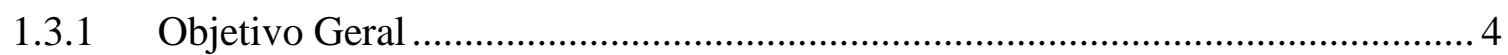

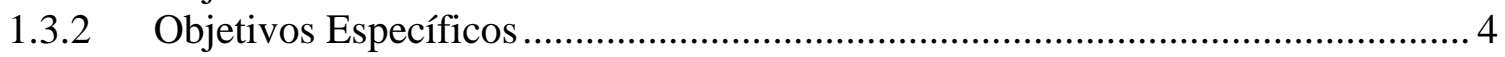

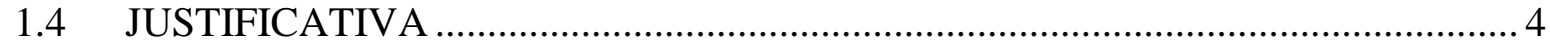

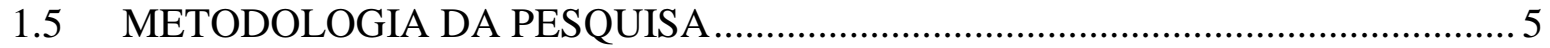

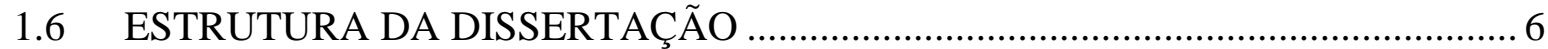

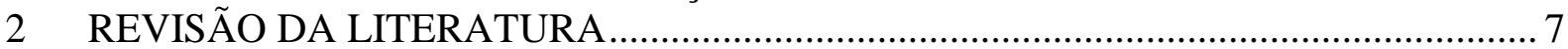

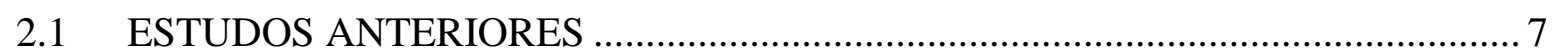

2.2 MODELOS DE EXPLORAÇÃO

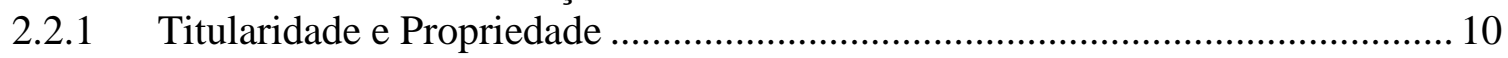

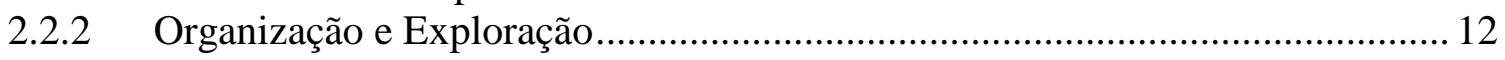

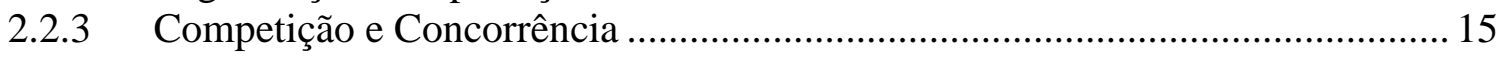

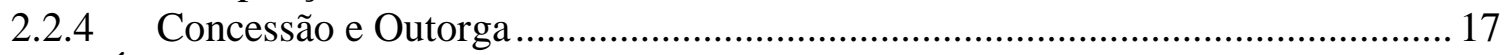

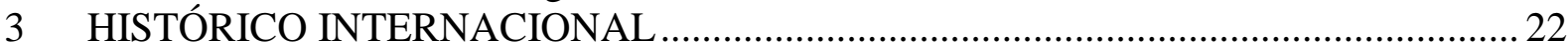

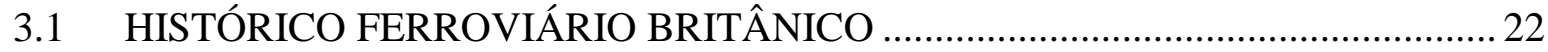

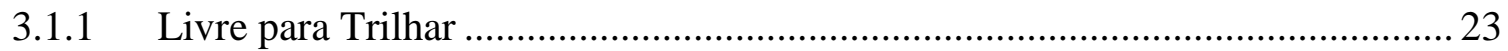

3.1.2 Déficit Fiscal, de Cargas e de Passageiros ....................................................... 26

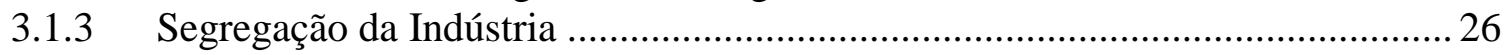

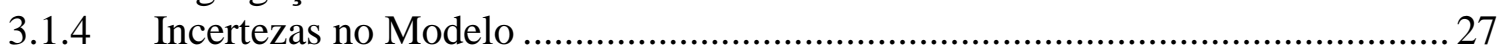

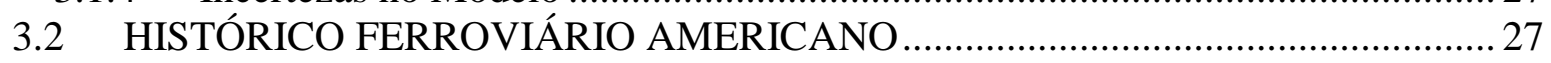

3.2.1 Competição e Discriminação de Preços ........................................................... 27

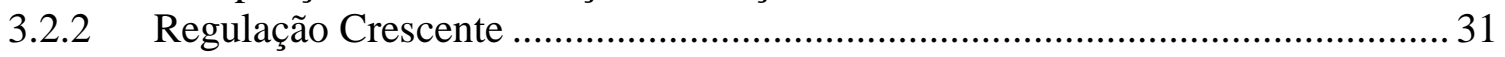

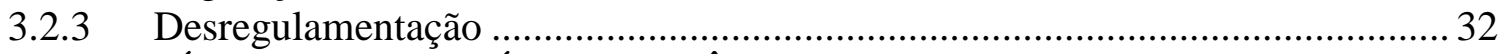

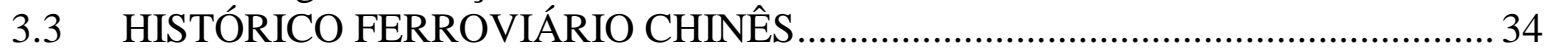

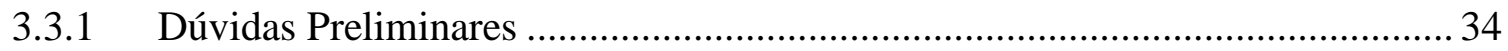

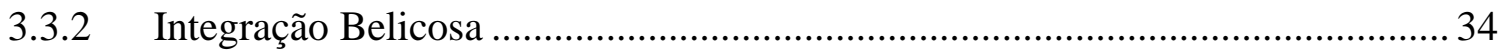

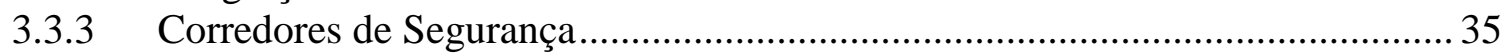

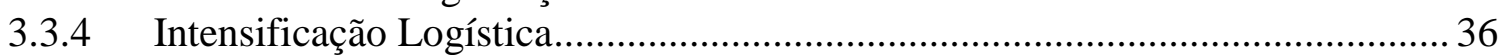

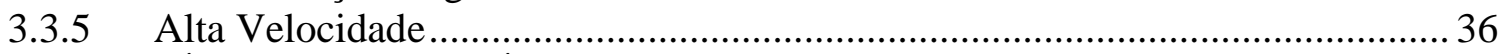

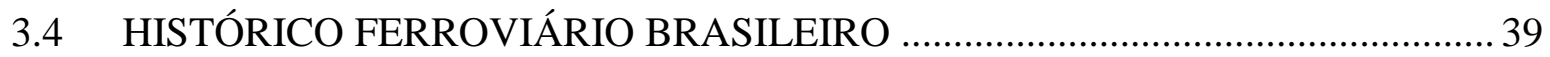

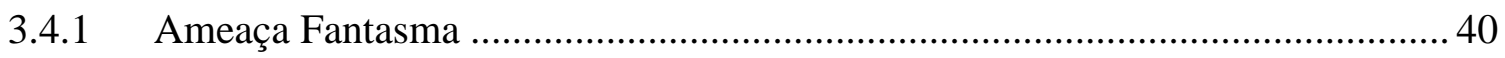

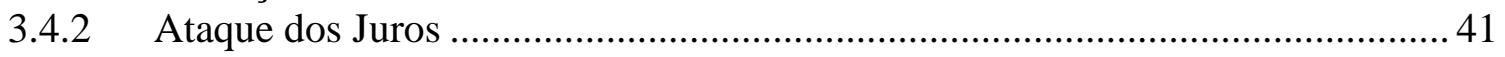

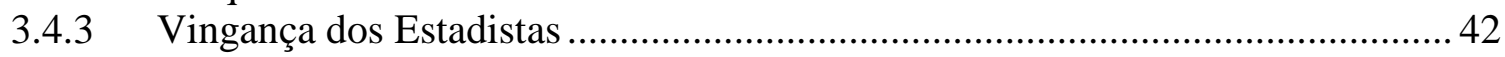

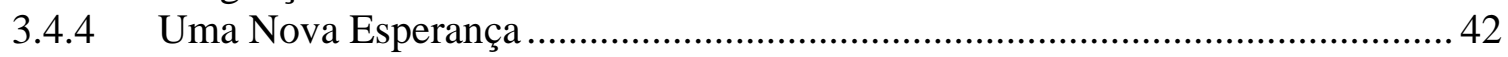

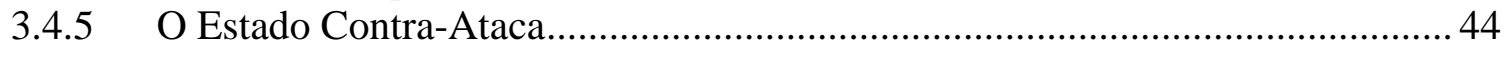

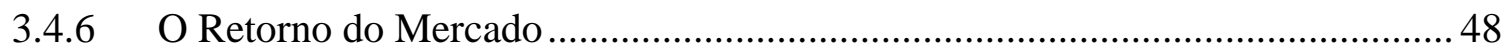

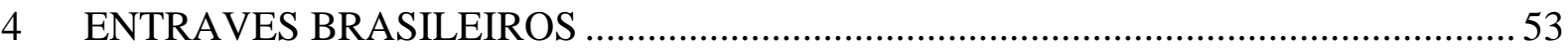

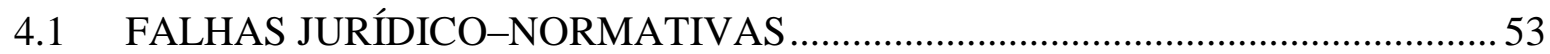

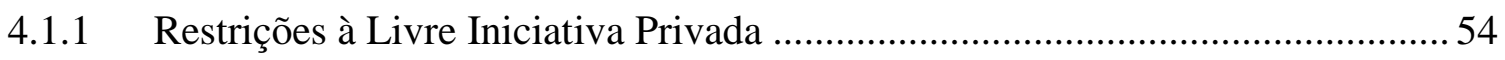

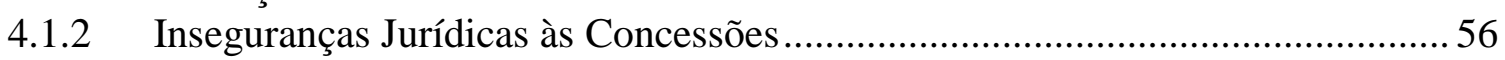

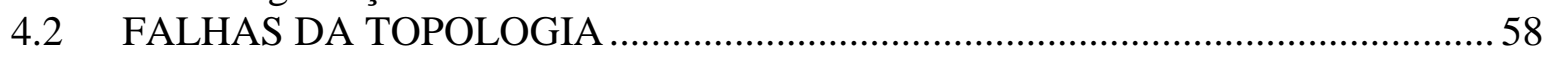

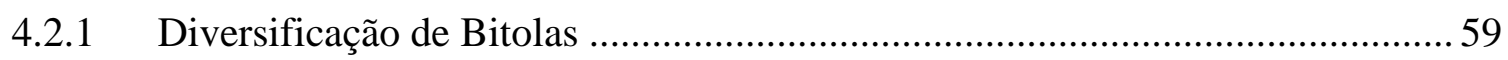

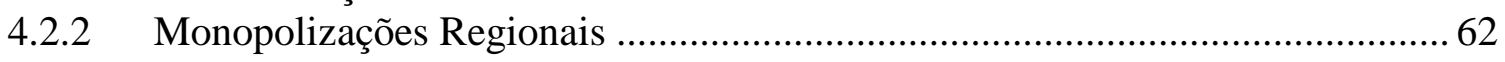

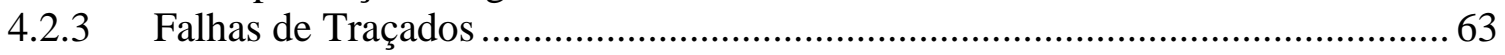

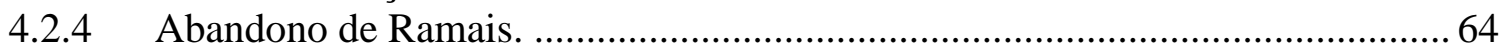




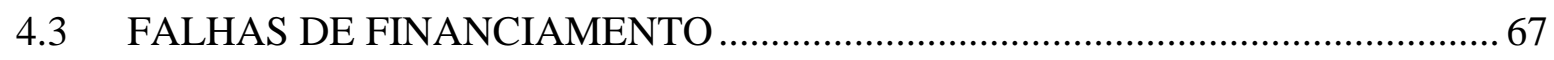

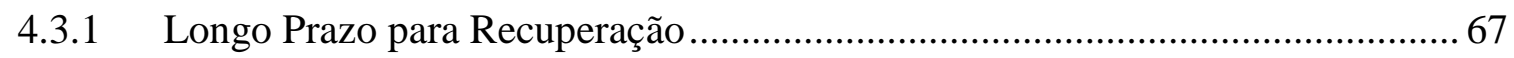

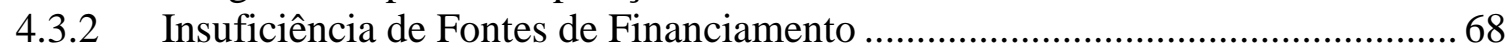

4.3.3 Insuficiência de Fontes de Receitas ................................................................ 71

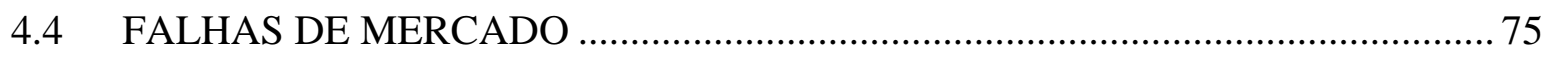

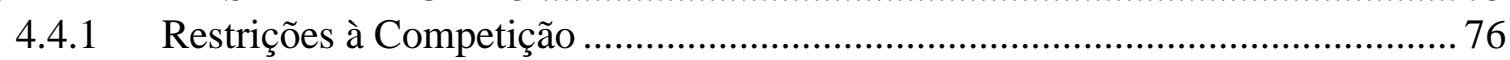

4.4.2 Natureza de quase Bens Públicos............................................................... 78

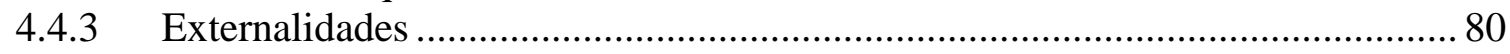

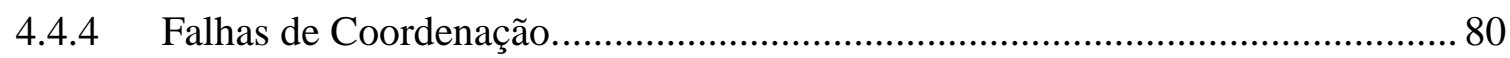

4.5 FALHAS DE GOVERNO............................................................................ 80

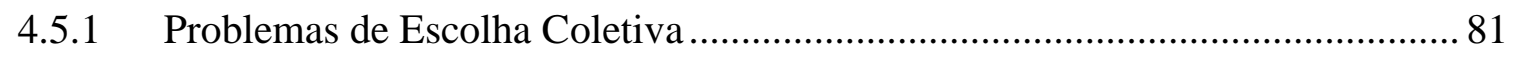

4.5.2 Problema Agente-Principal ........................................................................... 82

4.5.3 Inexistência de Incentivos a Eficiência .............................................................. 84

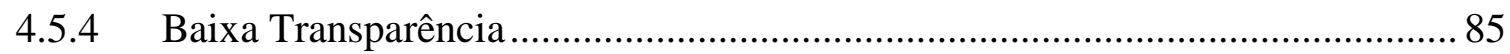

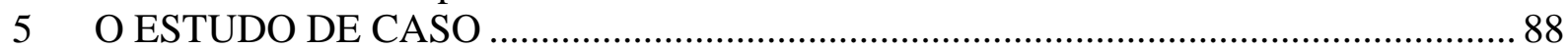

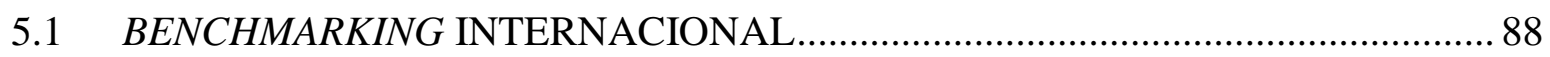

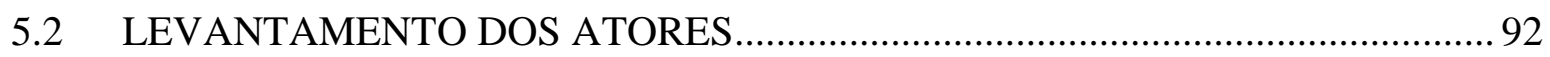

5.2.1 Instrumento de Pesquisa.................................................................................... 93

5.3 FAILURE MODE AND EFFECTS ANALYSIS (FMEA) ……………………......... 97

5.4 TÉCNICAS NÃO PARAMÉTRICAS ……………............................................ 99

5.4.1 Teste $\mathrm{X}^{2} \ldots \ldots \ldots \ldots \ldots$

5.4.2 Teste de Kruskall-Wallis ................................................................................. 99

5.4.3 Teste de Friedman ....……………………………………………………. 100

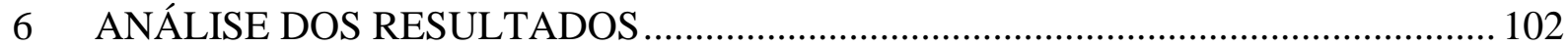

6.1 EXPLORAÇÃO DA INFRAESTRUTURA FERROVIÁRIA ……………………..... 102

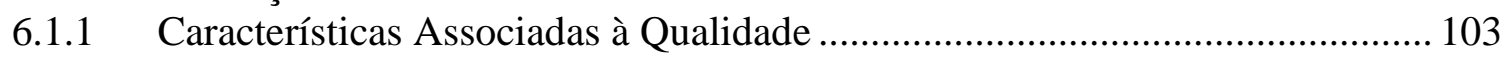

6.1.2 Características Associadas à Extensão ……………………………………….... 105

6.1.3 Características Associadas à Densidade............................................................ 106

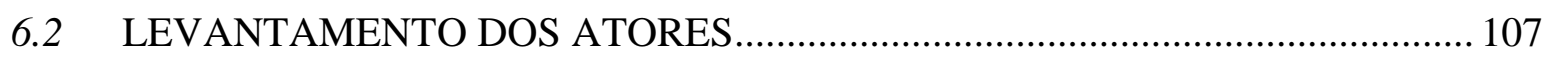

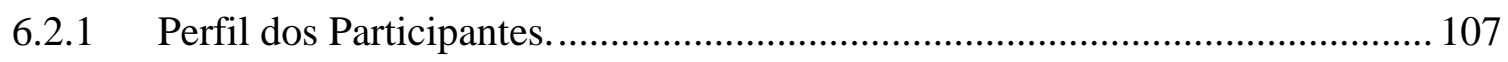

6.2.2 Avaliação do Setor Ferroviário ………………………………………………. 113

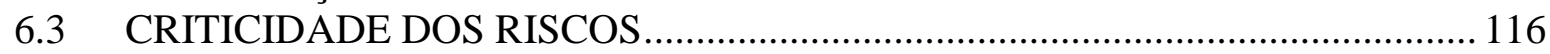

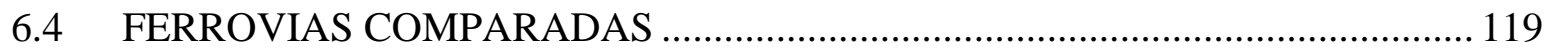

6.4.1 Variáveis Homogêneas................................................................................. 120

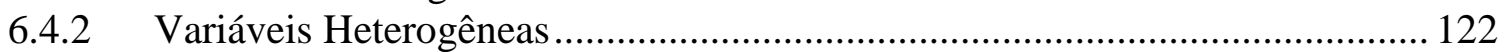

6.5 HISTÓRICO DAS POLÍTICAS REGULATÓRIAS …........................................... 127

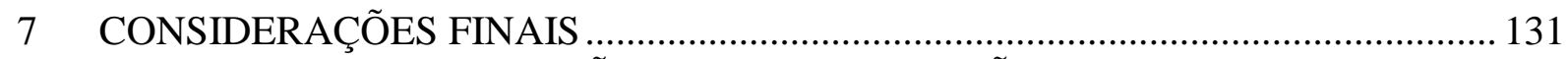

7.1 DESREGULAMENTAÇÃO E REPRIVATIZAÇÃO........................................... 132

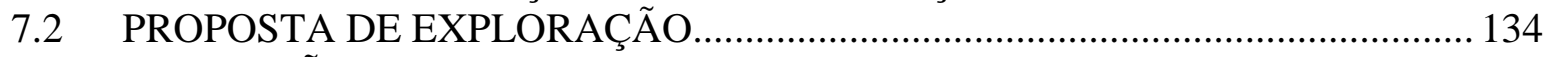

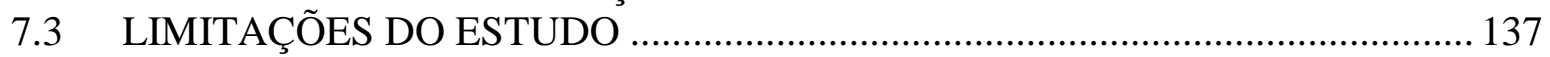

7.4 RECOMENDAÇÕES PARA TRABALHOS FUTUROS ……………………....... 137

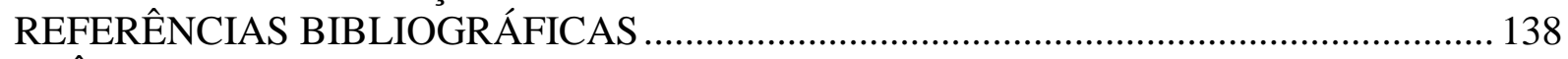

APÊNDICE A - Levantamento da Percepção dos Atores ...................................................... 150

APÊNDICE B - Frequência das Variáveis Homogêneas ....................................................... 158

APÊNDICE C - Extensão da Rede por ano e km............................................................... 160

APÊNDICE D - Dados sobre extensão, qualidade e densidade. ………………………….... 161

APÊNDICE E - Dados sobre bitola, População e PIB …………………………………….. 162 
LISTA DE TABELAS

Tabela 1.1 Matriz de Transportes do Brasil, em TKU, por anos selecionados .......................... 1

Tabela 2.1 Estudos anteriores sobre modelos de exploração ferroviária ................................. 7

Tabela 2.2 Exemplos de ferrovias integralmente privadas. .................................................... 11

Tabela 2.3 Exemplos de ferrovias integralmente públicas.................................................... 12

Tabela 2.4 Exemplos de ferrovias de titularidade públicas e gestão privada........................... 12

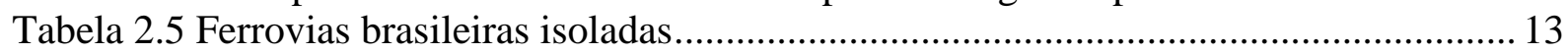

Tabela 2.6 Grau de separação entre exploração de infraestrutura e serviços de transportes ... 16

Tabela 2.7 Formas de outorga do transporte ferroviário no Brasil ....................................... 17

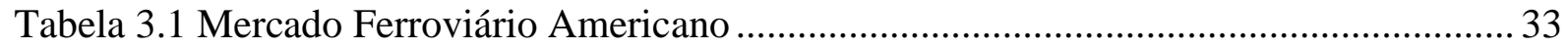

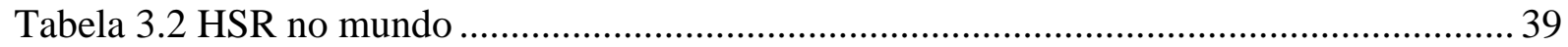

Tabela 3.3 Concessões oriundas da RFFSA e FEPASA (em km) …...................................... 43

Tabela 3.4 Ferrovias outorgadas à VALEC - Lei $\mathrm{n}^{\circ} 11.772$, de 17 de setembro de $2008 \ldots . . . .45$

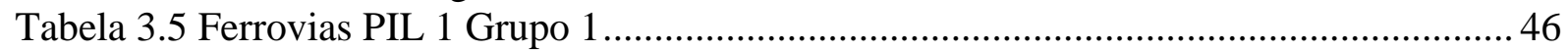

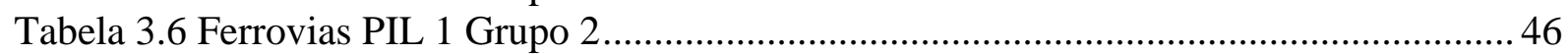

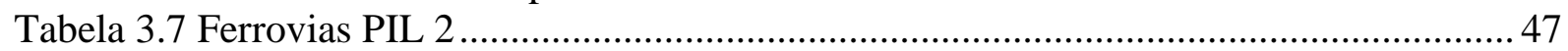

Tabela 4.1 Situação dos requerimentos de autorização para OFI em 2016 ............................. 57

Tabela 4.2 Mercado ferroviário de cargas alemão, britânico e sueco em 2007 .......................58

Tabela 4.3 Ramais abandonados ou inoperantes por concessionária em 2011 e 2017 ............ 65

Tabela 4.4 Investimento em infraestrutura de transportes no Brasil (\% do PIB)..................... 70

Tabela 4.5 Investimentos em infraestrutura no Brasil, 2001 - 2010 (\% do PIB) ................... 70

Tabela 4.6 Investimentos Federais em Transportes no Brasil, 2006-2015 (\% do PIB) .......... 71

Tabela 4.7 Principais concessionárias ferroviárias, em 2017 .............................................. 77

Tabela 4.8 Investimentos federais em ferrovias - PPA 2008-2011 e 2012-2015 ................... 84

Tabela 4.9 Extensão líquida da malha ferroviária do Brasil em 2017 (em km)..................... 87

Tabela 5.1 Características ferroviárias básicas dos países comparados .................................. 90

Tabela 5.2 Ferrovias selecionadas para a pesquisa juntos aos atores interessados ................. 96

Tabela 5.3 Critério de avaliação de Ocorrência adaptado...................................................... 97

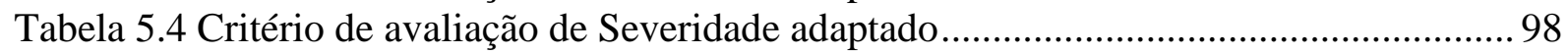

Tabela 6.1 Países amostrados por qualidade da infraestrutura.............................................. 104

Tabela 6.2 Resultado teste Kruskal-Wallis para a qualidade da infraestrutura..................... 105

Tabela 6.3 Países amostrados ordenados pela extensão total da malha ................................ 105

Tabela 6.4 Resultado teste Kruskal-Wallis para a extensão total da malha........................... 106

Tabela 6.5 Países amostrados ordenados pela densidade total da malha ............................. 106

Tabela 6.6 Resultado teste Kruskal-Wallis para a densidade total da malha ......................... 107

Tabela 6.7 Classificação das respostas pelas variáveis "Ator interessado" e "Tipo de

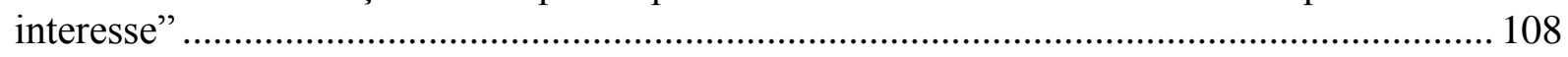

Tabela 6.8 Estatísticas descritivas das variáveis sobre a avaliação geral do setor ferroviário113

Tabela 6.9 Cotejo da percepção dos entrevistados por área de interesse ............................... 114

Tabela 6.10 Resultado dos testes estatísticos acerca das divergências de opiniões por áreas de

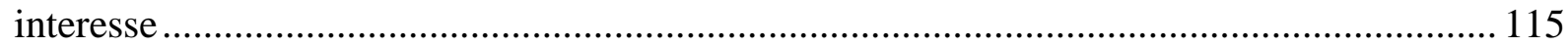

Tabela 6.11 Estatísticas descritivas do NPR do Setor de Transporte Ferroviário de Cargas. 116 Tabela 6.12 Estatísticas descritivas do NPR do Setor de Transporte Ferroviário de Passageiros

Tabela 6.13 Resultado do teste de Friedman para o PNR dos setores ferroviários de carga e

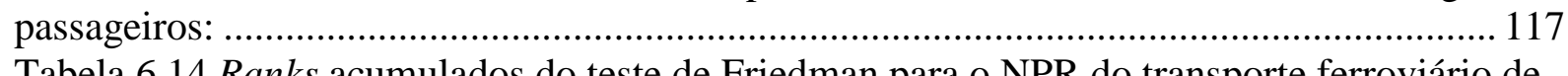

Tabela 6.14 Ranks acumulados do teste de Friedman para o NPR do transporte ferroviário de

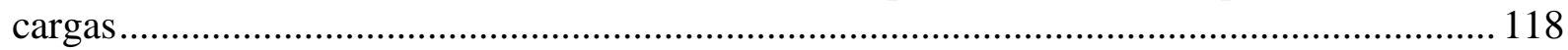

Tabela 6.15 Comparações múltiplas do NPR do transporte ferroviário de cargas ................ 118 
Tabela 6.16 Ranks acumulados do teste de Friedman para o NPR do transporte ferroviário de

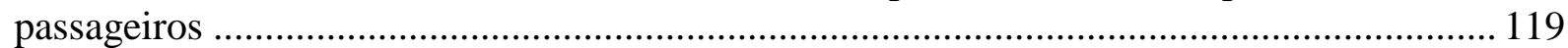

Tabela 6.17 Comparações múltiplas do NPR do transporte ferroviário de pasageiros .......... 119

Tabela 6.18 Variáveis homogêneas $(\alpha=5 \%)$ para as ferrovias do estudo ............................. 120

Tabela 6.19 Resultado do teste $X^{2}$ das variáveis heterogêneas para as ferrovias do estudo .. 123

Tabela 6.20 Resultado do teste de Friedman das variáveis heterogêneas para as ferrovias do

estudo

Tabela 6.21 Frequência e ranking da variável utilidade para as 10 ferrovias estudadas ....... 123

Tabela 6.22 Frequência da variável viabilidade para as 10 ferrovias estudadas.................... 125

Tabela 6.23 Frequência da variável prioridade para as 10 ferrovias estudadas ..................... 127

Tabela 6.24 Exemplos de tradeoff entre falhas de mercado e de governo que agravaram os

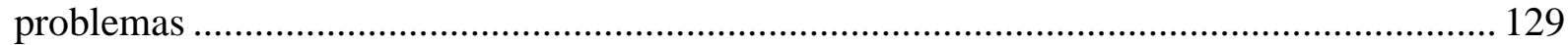

Tabela 7.1 Plano de ações sugerido para recuperação da modalidade ferroviária brasileira . 134

Tabela 7.2 Recomendações de modelos de exploração ....................................................... 136

Tabela B.1 Frequência da variável titularidade para as 10 ferrovias estudadas .................... 158

Tabela B.2 Frequência da variável exploração para as 10 ferrovias estudadas ...................... 158

Tabela B.3 Frequência da variável outorga para as 10 ferrovias estudadas ......................... 159

Tabela B.4 Frequência da variável bitola para as 10 ferrovias estudadas.............................. 159

Tabela C.1 Extensão da rede ferroviária por anos e países selecionados em $\mathrm{km}$................... 160

Tabela D.1 Qualidade, extensão e densidade por países selecionados ................................. 161

Tabela E.1 Bitola, população e PIB por países selecionados ............................................... 162 


\section{LISTA DE FIGURAS}

Figura 3.1 Desempenho do setor ferroviário americano entre 1964-2015 ............................ 33

Figura 3.2 Malha ferroviária chinesa - rede de alta velocidade......................................... 38

Figura 3.3 Ferrovias em estudo para renovação antecipada................................................ 50

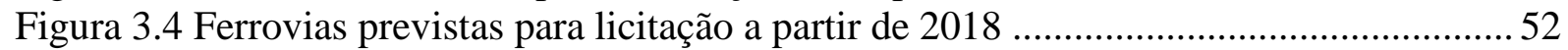

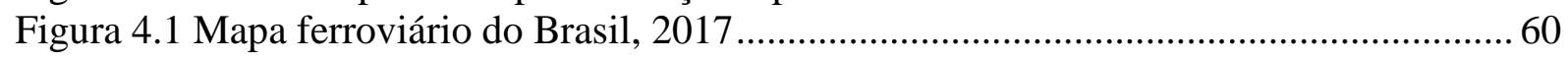

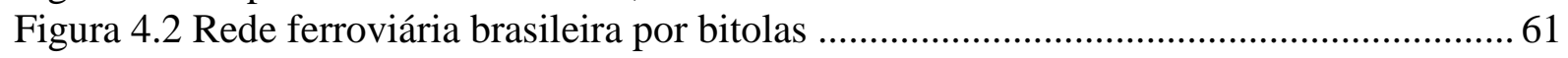

Figura 4.3 Rede ferroviária brasileira por concessionárias .................................................. 63

Figura 4.4 Padrão topológico de conexão ferroviária voltado para exportação sem competição

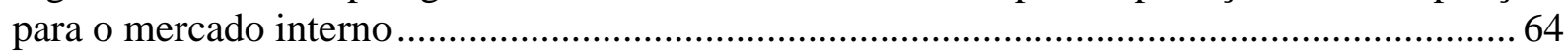

Figura 4.5 Ramais inoperantes na malha da concessionária Transnordestina Logística, em

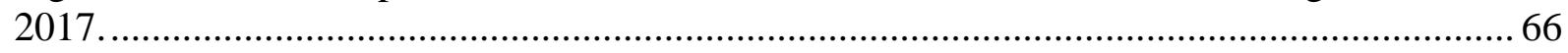

Figura 4.6 Variação das receitas e investimentos da União em Transportes, segundo as leis

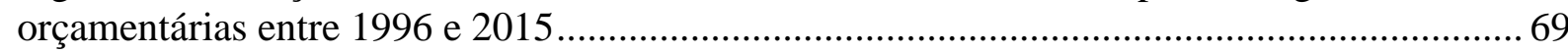

Figura 4.7 evolução dos investimentos em ferrovias: privado (concessionárias) e público

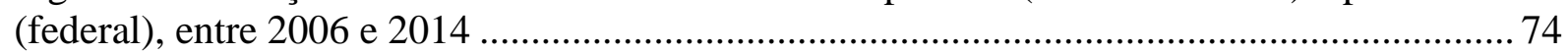

Figura 4.8 Evolução da produção de transporte ferroviário em bilhões de TKU, entre 1997 e

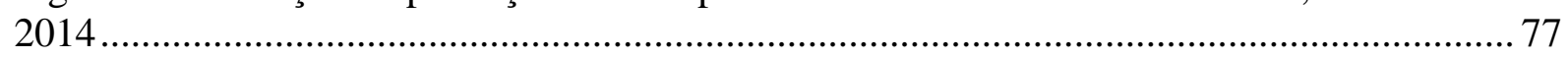

Figura 5.1 Período de registro dos dados do levantamento entre os atores interessados .......... 93

Figura 6.1 Divisão dos participantes por tipo de ator mais identificado .............................. 108

Figura 6.2 Divisão dos entrevistados por tipo de interesse ................................................. 109

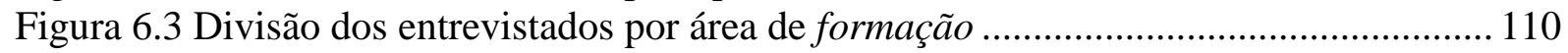

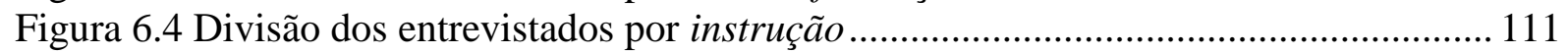

Figura 6.5 Divisão dos entrevistados por anos de experiência no setor ferroviário................ 112

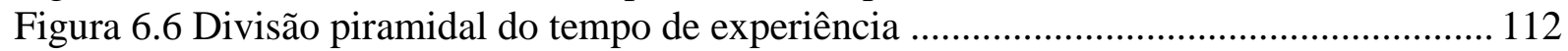

Figura 6.7 Síntese da avaliação geral entre os onze pilares pesquisados .............................. 115

Figura 6.8 Evolução da Rede Ferroviária (EUA, Brasil, China) .......................................... 126 


\section{LISTA DE SIGLAS E ABREVIAÇÕES}

$1^{\circ} \mathrm{B} \mathrm{Fv}-1^{\circ}$ Batalhão Ferroviário do Exército Brasileiro

$2^{\circ} \mathrm{B} \mathrm{Fv}-2^{\circ}$ Batalhão Ferroviário do Exército Brasileiro

ANPTrilhos - Associação Nacional dos Transportadores de Passageiros sobre Trilhos

ANTF - Associação Nacional dos Transportadores Ferroviários

ANTT - Agência Nacional de Transportes Terrestres

EFC - Estrada de Ferro Carajás

EFVM - Estrada de Ferro Vitória a Minas

EPL - Empresa de Planejamento e Logística

FCA - Ferrovia Centro-Atlântica S.A.

FEPASA - Ferrovia Paulista S.A.

FERROBAN - Ferrovias Bandeirantes S.A.

FERROESTE - Estrada de Ferro Paraná Oeste S.A.

FERRONORTE - Ferrovias Norte Brasil S. A.

FERROPAR - Ferrovia Paraná S.A.

FMEA - Failure Mode and Effects Analysis (Análise de Modo e Efeitos de Falha)

FND - Fundo Nacional de Desestatização

FNIF - Fundo Nacional de Investimento Ferroviário

FTC - Ferrovia Tereza Cristina S. A.

IME - Instituto Militar de Engenharia

LDO - Lei de Diretrizes Orçamentárias

LOA - Lei Orçamentária Anual

MT - Ministério dos Transportes Portos e Aviação Civil

NPR - Número de Prioridade de Risco

OCDE - Organização de Cooperação e Desenvolvimento Econômico

PIB - Produto Interno Bruto 
PKU - Passageiro/Quilômetro

PN - Passagem em Nível

PND - Programa Nacional de Desestatização

PPA - Plano Plurianual

PPP - Parcerias Público-Privadas

PRONURB - Programa Nacional de Segurança Ferroviária em Áreas Urbanas

RFFSA - Rede Ferroviária Federal S.A.

RTF - Regulamento dos Transportes Ferroviários

SR - Superintendência Regional

STF - Supremo Tribunal Federal

TCU - Tribunal de Contas da União

TIR - Taxa Interna de Retorno

TUP - Terminal de Uso Privado

TKU - Tonelagem por Quilômetro-Útil

TR - Taxa de Retorno

TU - Tonelada Útil

VALEC - Engenharia, Construções e Ferrovias S.A.

VPL - Valor Presente Líquido 


\section{INTRODUÇÃO}

O tema "exploração econômica da infraestrutura ferroviária" apresenta, no cenário nacional, considerável importância não apenas econômica, mas, principalmente, social devido à necessidade de haver um setor de transportes forte, eficiente e de baixo custo. Na literatura é dominante o entendimento de que há correlação entre a provisão de infraestrutura e a prosperidade, o bem-estar, a geração de empregos, a redução da pobreza, o aumento do acesso ao mercado, à saúde e à educação (Lodge et al., 2017). Dessa forma, é essencial ao Brasil estudar as melhores práticas internacionais na exploração do modo de transportes ferroviário, a fim de se dar publicidade e obter compreensão dos erros e acertos dessa indústria tão importante para o desenvolvimento econômico e o bem-estar social.

\subsection{APRESENTAÇÃO}

A matriz de transporte de cargas do Brasil é, essencialmente, "rodoviarista". Em 2015, 65\% das cargas foram transportadas por rodovias enquanto o modo ferroviário transportava apenas $15 \%$ das cargas em termos de $\mathrm{TKU}^{1}$ (EPL, 2016).

A meta de reequilibrar a matriz de transportes, apresentada pelo Governo Federal, em 2007, no Plano Nacional de Logística de Transpores, está longe de ser alcançada. Pelo contrário, a matriz de transportes é atualmente mais desequilibrada do que era quando da idealização do plano, segundo os levantamentos da iniciativa privada, e do próprio governo, como ilustrado na tabela 1.1:

Tabela 1.1 Matriz de Transportes do Brasil, em TKU, por anos selecionados

\begin{tabular}{lcccc}
\hline & $\mathbf{2 0 0 7}$ & $\mathbf{2 0 1 1}$ & $\mathbf{2 0 1 2}$ & $\mathbf{2 0 1 5}$ \\
\hline Rodoviário & $58 \%$ & $52 \%$ & $61,1 \%$ & $65 \%$ \\
Ferroviário & $25 \%$ & $30 \%$ & $20,7 \%$ & $15 \%$ \\
Aquaviário & $13 \%$ & $13 \%$ & $13,6 \%$ & $16 \%$ \\
Dutoviário & $3,6 \%$ & $5 \%$ & $4,2 \%$ & $4 \%$ \\
Aéreo & $0,4 \%$ & - & $0,4 \%$ & - \\
\hline Fontes: & Brasil, 2007 & MT, 2012 & CNT, 2014 & EPL, 2016
\end{tabular}

A escassez de transporte ferroviário de cargas brasileiro não está somente no tamanho reduzido de sua malha, mas, também, na sua baixa produtividade, falta de interligação entre as linhas e, principalmente, na quantidade reduzida de investimentos nesse setor (Lang, 2007). O transporte ferroviário de passageiros é inexpressivo no Brasil. Em todo o país, apenas três linhas regionais operam regularmente ${ }^{2}$ (Moraes, 2017). A Estrada de Ferro Vitória Minas

\footnotetext{
${ }^{1}$ Toneladas transportadas por quilômetro útil.
} 
(EFVM) transporta, em média, anualmente, cerca de 1 milhão de passageiros entre Cariacica/ES e Belo Horizonte/MG, enquanto a Estrada de Ferro Carajás (EFC) transporta, em média, 350 mil pax/ano entre São Luís/MA e Paraupebas/PA, ambas operadas pela concessionária Vale/VLI (CNT, 2015). Além dessas duas, há ainda uma linha regional com extensão de 110 km, entre Curitiba e Paranaguá, operada pela Serra Verde Express Ltda. na malha sob concessão da Rumo-ALL, malha sul. As demais linhas de passageiros em operação são turísticas, não regulares, sem obrigação de regularidade ou exclusividade. No total, em 2015, foram transportados 1,8 milhão de passageiros (Moraes, 2017).

A qualidade da infraestrutura ferroviária brasileira ocupa assim posição incompatível com o tamanho de sua economia. Segundo o Global Competitiveness Report do World Economic Forum (WEF, 2016), o Brasil tinha, em 2016, a $7^{\text {a }}$ maior economia interna, com PIB de US\$ 1.772,6 bilhões enquanto ocupava a $93^{\mathrm{a}}$ posição quanto à qualidade da infraestrutura ferroviária ${ }^{3}$.

O Governo Federal a fim de diminuir o chamado Custo Brasil, equilibrar a matriz de transportes e desenvolver a economia nacional, desde meados de 2000, vem tentando, sem sucesso, ampliar e conceder a infraestrutura ferroviária à exploração de agentes privados.

O Estado tem como meta ampliar a participação do setor ferroviário na matriz de transportes de cargas, em TKU, para 32\% até 2025 (Brasil, 2007).

Essa ampliação resultaria em redução do Custo Brasil, dos gastos provenientes com acidentes nas estradas, da poluição, entre outras externalidades negativas. Apesar da reconhecida importância teórica e empírica, os investimentos em infraestrutura nem sempre recebem a prioridade que deveriam e são candidatos preferenciais a sofrerem cortes orçamentários durante os processos de ajuste fiscal (Orair, 2016).

Além disso, o governo não tem recursos para investir em infraestrutura. Os investimentos públicos têm apresentado tendência de crescimento negativo em relação ao PIB desde 1975 (Azeredo, 2014; Mendes, 2015; Orair, 2016).

As despesas em previdência, saúde, educação e segurança são prioritárias no Orçamento da União. A alternativa apontada para solução do déficit de infraestrutura é permitir parcerias de

\footnotetext{
${ }^{2}$ Segundo Moraes (2017), o transporte de passageiros na linha Corcovado - Cosme Velho, na cidade do Rio de Janeiro, com extensão de 3,8km é classificada como regular, entretanto, o anuário estatístico de 2017 do Ministério dos Transportes, Portos e Aviação Civil (MTPA) lista apenas as duas linhas principais como regulares.

${ }^{3}$ WEF (2016)
} 
investimento com o setor privado para a exploração da infraestrutura. Todavia, as tentativas recentes ${ }^{4}$ do governo federal não foram exitosas.

Segundo Azeredo (2014), o governo federal idealizou, em 2004, o aproveitamento da faixa de domínio da EF-222, para a implantação do trem de alta velocidade entre Rio de Janeiro, São Paulo e Campinas. O primeiro edital para licitação da exploração ferroviária do trem-bala foi lançado em 2010, sendo que as obras deveriam ter ficado prontas em 2016 para as Olimpíadas do Rio de Janeiro. Todavia, após sucessivos adiamentos e mudanças da modelagem da concessão, a exploração ferroviária não teve interessados no leilão realizado em 2011, não sendo mais relançado.

Os Planos de Investimento em Logística - Ferrovias - 1 e 2, lançados pelo Governo Federal, respectivamente, em 2012 e 2015, entre outras tentativas, procuraram efetuar parcerias de investimento com o setor privado, a fim de aumentar e melhorar a infraestrutura ferroviária nacional. Entretanto, estes Planos de Investimento em Logística também não alcançaram os resultados propostos.

Não obstante, outros países, aproveitando-se de abordagens variadas para exploração da infraestrutura ferroviária, têm ampliado e aperfeiçoado suas infraestruturas ferroviárias.

Investigar como outros países exploram suas malhas ferroviárias contribuirá para elaboração do desenho institucional, jurídico, técnico e econômico-financeiro dos futuros contratos para exploração da infraestrutura ferroviária, não apenas pelo modo usual das concessões comuns, mas até mesmo em outros formatos de outorgas. Isto permitirá ao país atingir sua meta de equilíbrio da matriz de transportes, com ampliação da rede e, em última análise, favorecerá o desenvolvimento da economia nacional.

\subsection{FORMULAÇÃO DO PROBLEMA}

Desde meados de 1990, nem a privatização do sistema ferroviário e tampouco a construção direta de novas infraestruturas ferroviárias permitiram a ampliação e modernização da rede ferroviária brasileira, em escala compatível com a sua economia interna. Atualmente, a rede possui cerca de $30.000 \mathrm{~km}$ (Brasil, 2017), aproximadamente a mesma ordem de grandeza de meados de 1920. Contudo, segundo levantamentos do Tribunal de Contas de União, apenas 10 mil km de trilhos são efetivamente explorados. Os quase dois terços restantes estão abandonados ou subutilizados (Felix e Cavalcante Filho, 2016).

\footnotetext{
${ }^{4}$ Desde 1996 até 2016, apenas três trechos novos foram contratados entre o governo federal e a iniciativa privada. Dois trechos são subconcessões da EF-151 da estatal VALEC com a Vale/VLI. O terceiro trecho é a Nova Transnordestina, uma sociedade entre VALEC, CSN, Finor, BNDES, BNB e Sudene. (CSN, 2017)
} 
Acrescente-se que todas as tentativas de Parcerias Público-Privadas (PPP), a partir dos anos 2000, para construção de novos ramais ferroviários, tanto de carga quanto de passageiros, fracassaram, incluindo o trem de alta velocidade entre Rio de Janeiro e Campinas, a ferrovia Nova Transnordestina, os Planos de Investimento em Logística - Ferrovias - 1 e 2, entre outras tentativas. No mesmo período, a exploração de outras infraestruturas de transportes pelo setor privado experimentou novos ciclos de concessão, com alterações nos critérios de equilíbrio econômico-financeiros.

No Brasil, não há embasamento teórico para elaboração de políticas públicas no modo ferroviário, no tocante a como e em que projeto investir, prioritariamente (Lang, 2007). Assim, investigar as alternativas de exploração da infraestrutura ferroviária a partir de uma análise comparada do setor ferroviário no mundo e do setor de infraestrutura no Brasil, de modo a apontar para os modelos de maior adesão do mercado à luz de um benchmaking, é o problema proposto desta pesquisa. Dessa forma, ficam as seguintes questões de investigação:

(i) "Quais são os modelos de exploração da infraestrutura ferroviária compatíveis com o mercado brasileiro?"

(ii) "Quais são os modelos de exploração da infraestrutura ferroviária preferidos pelos atores interessados brasileiros?"

\subsection{OBJETIVOS}

\subsubsection{Objetivo Geral}

O objetivo geral do trabalho é identificar os modelos de exploração da infraestrutura ferroviária compatíveis com o mercado ferroviário nacional.

\subsubsection{Objetivos Específicos}

Os objetivos específicos são:

a) Investigar os modelos de exploração de infraestruturas de transporte ferroviário.

b) Comparar os modelos de exploração ferroviária adotados no mundo.

c) Comparar os modelos de exploração de infraestrutura adotados no Brasil;

d) Avaliar junto ao mercado de concessionários e usuários, além dos órgãos de regulação e controle, as alternativas de exploração ferroviária.

\subsection{JUSTIFICATIVA}

Nos últimos anos, o Brasil tem se deparado com a necessidade de enfrentar seus principais gargalos logísticos, no intuito de mitigar ou diminuir os impactos desses entraves (Peixoto 
Filho, 2016). Todavia, no modo ferroviário os resultados alcançados pela exploração direta ou indireta foram insuficientes.

Apesar dos avanços alcançados, pelas concessões ferroviárias iniciadas em meados de 1990, em termos de diminuição de acidentes e aumento da produtividade, o mercado ferroviário brasileiro é incompleto e insuficiente (Nunes, 2006; Felix e Cavalcante Filho, 2016; Sampaio \& Daychoum, 2017). Muitas melhorias precisam ser feitas, principalmente na modelagem de futuras outorgas a fim de permitir a ampliação do mercado ferroviário na matriz de transportes brasileira.

A ausência de contratos de concessão de infraestrutura de transporte ferroviário de cargas, desde 2004, evidencia falha de mercado e de governo. A densidade ferroviária, 3,5 km de ferrovia por $1000 \mathrm{~km}^{2}$ do território e a posição do Brasil, 93º, em ranking internacional de qualidade entre 138 nações sugerem que o Brasil está relativamente longe da fronteira de melhores práticas e resultados no setor de transporte ferroviário (Frischtak, 2013).

A maioria das propostas de parcerias tem como objetivo estratégico buscar no setor privado recursos que complementem os recursos públicos, que têm sido declinantes em decorrência de crise fiscal, elevação de despesas obrigatórias e busca de superávit primário.

A evolução do mercado de parcerias em transportes pressupõe a existência de algumas condições básicas: ambiente apropriado, compromisso político, adequação dos parceiros privados, interesse do mercado, recursos humanos disponíveis, preparação do projeto, vantagem monetária, transparência, participação popular, e competição (Senna, 2014).

Essa pesquisa contribuirá não apenas para o meio acadêmico, mas também para o sistema econômico e os órgãos de regulação e planejamento, uma vez que analisará quais são os fatores que geram entraves para o desenvolvimento do modo ferroviário no Brasil. Com base nos resultados positivos encontrados nos demais modelos de exploração da infraestrutura no País, somado aos pontos positivos encontrados no modelo ferroviário em outros países, então, será possível propor um modelo de parceria de investimentos que incentive o desenvolvimento da infraestrutura ferroviária no Brasil. Deste modo, esta pesquisa contribuirá para o desenvolvimento acadêmico sobre o tema e, também, contribuirá para a redução do custo Brasil, desenvolvimento econômico do país e melhoria da regulação.

\subsection{METODOLOGIA DA PESQUISA}

A metodologia da dissertação será dividida nas seguintes etapas descritas a seguir:

i) Revisão bibliográfica: nesta fase é levantada a base teórica, no qual são estudados os modelos de exploração de infraestruturas ferroviárias nos mercados mais relevantes; o 
histórico internacional das reformas regulatórias, a fim de identificar os mecanismos que incentivam a participação privada no mercado de provisão de infraestrutura ferroviária.

ii) Formação de um banco de dados a partir de fontes primárias e secundárias dos mercados mais relevantes para compreensão e caracterização do setor ferroviário.

iii) Entrevista com especialistas no setor ferroviário, a fim de identificar os principais gargalos e validar o questionário de pesquisa.

iv) Estudo da percepção dos principais atores interessados (concessionários, usuários, agentes reguladores, planejadores, legisladores, controladores e acadêmicos) quanto às formas de exploração do mercado ferroviário. e

iv) Análises dos resultados: o desenvolvimento do método e sua aplicação no estudo de caso visa revelar as variáveis que atuam dentro da modelagem de exploração ferroviária identificando as estratégias mais compatíveis com o cenário nacional.

\subsection{ESTRUTURA DA DISSERTAÇÃO}

A dissertação estará estruturada em sete capítulos, incluindo a introdução. O Capítulo 2 apresentará uma revisão de estudos similares e introduzirá diversos conceitos relativos ao tema. O capítulo 3, apresentará um comparativo histórico sobre os principais benchmarks ferroviários e Brasil, desde o início de suas redes até o momento atual. $\mathrm{O}$ capítulo 4 descreverá e analisará os principais entraves brasileiros. O capítulo 5 apresenta a base de dados, o estudo de caso da pesquisa junto aos stakeholders (concessionários, planejadores, reguladores e legisladores) e o método de análise dos dados. O capítulo 6 discorrerá sobre os resultados obtidos na pesquisa. Por fim, o capítulo 7 apresentará as principais conclusões e recomendações da pesquisa. 


\section{REVISÃO DA LITERATURA}

\subsection{ESTUDOS ANTERIORES}

O estudo da indústria de transporte ferroviário teve notável importância na pesquisa acadêmica, notadamente, econômica (Waters II, 2007). Todavia, com a desregulamentação do mercado ferroviário nas Américas, inicialmente ${ }^{5}$ no Canadá a partir de 1967 (Waters II, 2007), seguido dos Estados Unidos, em 1980 (Waters II, 2007; Wilson \& Wilson, 2001), e de diversos outros países da América Latina (Müller \& Aragonés, 2013), a exemplo do Brasil, em 1995, a pesquisa acadêmica foi levada a um intenso confronto comparativo sobre os prós e os contras de cada modelo de exploração à medida que as reformas foram amadurecendo.

Com a decisão da União Europeia de unificar o mercado ferroviário e aumentar sua competitividade, notadamente, a partir de 1991, por meio de uma estratégia de desverticalização da malha (unbundling), a literatura internacional passou a estudar um leque mais amplo de abordagens em termos de exploração da modalidade ferroviária de transporte, tanto de carga quanto de passageiros.

Segundo Peixoto et al. (2017) verificaram em estudo bibliométrico sobre o financiamento ferroviário, o aumento do interesse acadêmico modelou-se segundo uma tendência crescente, entre 1991 e 2016. Nesse período, a produção científica internacional cresceu segundo uma regressão linear com inclinação de 1,54 e $R^{2}$ de 0,79 . O recente êxito chinês em expandir os serviços de transporte ferroviário de cargas e passageiros, principalmente através dos trens de alta velocidade, trouxe novo interesse acadêmico pelo tema na última década. Na tabela 2.1, são expostas algumas das pesquisas comparativas entre os modelos adotados em diversos países.

Tabela 2.1 Estudos anteriores sobre modelos de exploração ferroviária

\begin{tabular}{cclc}
\hline Autor & Ano & \multicolumn{1}{c}{ Contribuição } & Países analisados \\
\hline Wu \& Nash 2000 & $\begin{array}{l}\text { Forneceu uma descrição detalhada do sistema } \\
\text { ferroviário chinês a partir de meados da década } \\
\text { de 1990 e discutiu uma série de propostas de } \\
\text { reforma para a China. }\end{array}$ & $\begin{array}{l}\text { China, India, Japão, Estados e Grã-Bretanha. } \\
\text { Und }\end{array}$ \\
\hline
\end{tabular}

5

Uma Comissão Real de Transportes, em 1962, no Canadá, recomendou que os regulamentos das vias férreas canadenses fossem reduzidos para dar-lhes maior liberdade para responder à concorrência intermodal e maior flexibilidade nas taxas de negociação com os carregadores. O National Transportation Act, de 1967, adotou esses princípios (Waters II, 2007). 


\begin{tabular}{|c|c|c|c|}
\hline Autor & Ano & Contribuição & Países analisados \\
\hline Campos & 2001 & $\begin{array}{l}\text { Analisou modelos de desestatização de malhas } \\
\text { ferroviárias na América Latina, e mostrou que a } \\
\text { outorga por concessão pode ser um mecanismo } \\
\text { viável para a privatização ferroviária em alguns } \\
\text { países em desenvolvimento. Evidenciou que } \\
\text { problemas regulatórios, inevitavelmente, } \\
\text { emergem durante e após o processo de } \\
\text { concessão. }\end{array}$ & Brasil e México \\
\hline Peci & 2002 & $\begin{array}{l}\text { Analisou e descreveu os modelos regulatórios a } \\
\text { partir de uma perspectiva histórica. }\end{array}$ & Brasil e Estados Unidos. \\
\hline Cavalcanti & 2002 & $\begin{array}{l}\text { Analisou a evolução da regulação do mercado } \\
\text { de transportes. Identificou a existência de } \\
\text { baixos níveis de coordenação estatal sobre o } \\
\text { mercado de transportes, caracterizada pela } \\
\text { pulverização de órgãos pouco autônomos e } \\
\text { desagregados. }\end{array}$ & Argentina e Brasil \\
\hline Friebel et al. & 2004 & $\begin{array}{l}\text { Analisaram os efeitos da desregulamentação no } \\
\text { mercado europeu. Mostrou que houve efeitos } \\
\text { positivos sobre a produtividade dos mercados } \\
\text { reformados, todavia, com variada diversificação } \\
\text { de resultados. }\end{array}$ & $\begin{array}{l}\text { Áustria, Bélgica, Dinamarca, } \\
\text { Finlândia, Alemanha, Itália, } \\
\text { Holanda, Portugal, Espanha, } \\
\text { Suécia, e Reino Unido. }\end{array}$ \\
\hline Friebel et al. & 2007 & $\begin{array}{l}\text { Analisaram os modelos de exploração } \\
\text { ferroviária e defendem a adoção do modelo } \\
\text { americano como o mais apropriado para a } \\
\text { Rússia. }\end{array}$ & $\begin{array}{l}\text { Rússia, Bulgária, República } \\
\text { Tcheca, Hungria, Polônia, } \\
\text { Romênia e Eslováquia. }\end{array}$ \\
\hline $\begin{array}{l}\text { Ludvigsen \& } \\
\text { Osland }\end{array}$ & 2009 & $\begin{array}{l}\text { Analisaram a adoção da política europeia de } \\
\text { abertura do mercado de transporte ferroviário } \\
\text { de carga. Identificaram que os países estudados } \\
\text { responderam com adesão limitada à política de } \\
\text { abertura, resultando em insignificância do } \\
\text { aumento de competitividade. }\end{array}$ & $\begin{array}{l}\text { Noruega, Finlândia, Suécia, } \\
\text { Polônia, República Tcheca, } \\
\text { Romênia, Áustria, Hungria e } \\
\text { Grécia. }\end{array}$ \\
\hline Wang et al. & 2012 & $\begin{array}{l}\text { Analisaram diferentes modelos de } \\
\text { financiamento de transportes ferroviários. } \\
\text { Identificaram a importância do financiamento } \\
\text { público nacional na evolução do transporte } \\
\text { ferroviário versus as limitações de } \\
\text { administrações locais em desenvolverem o } \\
\text { moro ferroviário de transporte. }\end{array}$ & China, Japão, Índia e EUA. \\
\hline $\begin{array}{l}\text { Bray \& } \\
\text { Sayeg }\end{array}$ & 2013 & $\begin{array}{l}\text { Analisaram diferentes modelos de participação } \\
\text { privada, competição e propriedade de sistemas } \\
\text { de transportes ferroviários urbanos. } \\
\text { Identificaram a importância da liderança estatal } \\
\text { no planejamento e gerência dos sistemas. }\end{array}$ & $\begin{array}{l}\text { Tailândia, Malásia, Filipinas e } \\
\text { Singapura. }\end{array}$ \\
\hline $\begin{array}{l}\text { Mizutani \& } \\
\text { Uranishi }\end{array}$ & 2013 & $\begin{array}{l}\text { Constatou que os resultados da aplicação do } \\
\text { open access dependem da densidade do tráfego } \\
\text { na malha ferroviária. }\end{array}$ & Países europeus e asiáticos. \\
\hline
\end{tabular}




\begin{tabular}{|c|c|c|c|}
\hline Autor & Ano & Contribuição & Países analisados \\
\hline $\begin{array}{l}\text { Müller \& } \\
\text { Aragonés }\end{array}$ & 2013 & $\begin{array}{l}\text { Analisaram, descreveram e compararam efeitos } \\
\text { de privatização por concessão versus } \\
\text { desregulamentação. }\end{array}$ & Argentina e Estados Unidos. \\
\hline Pittman & 2013 & $\begin{array}{l}\text { Analisou o comportamento do setor ferroviário } \\
\text { em países da extinta URSS. Identificou } \\
\text { significativa aversão a desestatização do } \\
\text { sistema, especificamente na Rússia, que embora } \\
\text { permita a participação privada exerce forte } \\
\text { atuação estatal por meio da RZD. }\end{array}$ & $\begin{array}{l}\text { Rússia, Cazaquistão, Estônia, } \\
\text { Letônia, Lituânia, Ucrânia } \\
\text { Uzbequistão e Geórgia. }\end{array}$ \\
\hline $\begin{array}{l}\text { Laurino et } \\
\quad \text { al. }\end{array}$ & 2015 & $\begin{array}{l}\text { Analisaram, descreveram e comentaram } \\
\text { diferentes modelos de exploração ferroviária. }\end{array}$ & $\begin{array}{l}\text { Austrália, Áustria, Brasil, } \\
\text { Canadá, Chile, China, França, } \\
\text { Alemanha, Grã-Bretanha, } \\
\text { Hungria, Itália, Índia, Japão, } \\
\text { México, Rússia, Espanha, } \\
\text { África do Sul, Suécia, Turquia } \\
\text { e Estados Unidos da América. }\end{array}$ \\
\hline $\begin{array}{l}\text { Currie \& De } \\
\text { Gruyter }\end{array}$ & 2016 & $\begin{array}{l}\text { Avaliaram, por meio de benchmarking, o } \\
\text { desempenho dos serviços de trens leves de } \\
\text { passageiros entre públicos e privados. } \\
\text { Identificou melhor desempenho das empresas } \\
\text { privadas em relação às públicas. }\end{array}$ & Austrália e Estados Unidos \\
\hline Tomeš & 2017 & $\begin{array}{l}\text { Não identificou aumento de competitividade na } \\
\text { Europa após a adoção das reformas regulatórias } \\
\text { em prol da segregação entre infraestrutura e } \\
\text { operação dos trens. }\end{array}$ & 27 países europeus \\
\hline
\end{tabular}

Os estudos acadêmicos têm demonstrado que há diversos modelos para exploração ferroviária, desde os integralmente públicos até os integralmente privados, com diversos arranjos quanto à manutenção dos trilhos e operação dos trens, tanto de carga quanto de passageiros, bem como de promoção da competição (Pittman, 2004; Laurino et al., 2015).

\subsection{MODELOS DE EXPLORAÇÃO}

O negócio das empresas ferroviárias, tipicamente, implica em grande quantidade de interações baseadas em investimentos de longo prazo e, na sua maioria, afundados (Friebel et al., 2007). A intensidade de capital e os riscos financeiros associados às ferrovias resultam em uma estrutura de mercado onde, geralmente, o número de empresas é limitado. Muitas vezes apenas uma firma serve um determinado mercado. Quando existe a possibilidade de competição intramodal, também há o risco de competição ruinosa (Waters II, 2007). Não obstante, a complexidade da indústria ferroviária permite a existência de diversos arranjos de organização e operação da infraestrutura ferroviária. 
Neste subitem, são abordadas as principais estratégias adotadas no mundo. O primeiro dilema diz respeito às possibilidades de exploração, quanto aos direitos de propriedade. A segunda questão a enfrentar são as estratégias principais de organização da indústria, a fim de se mitigar ou eliminar o comportamento de monopolista natural da ferrovia, a segregação da indústria em termos de unbundling e suas consequências em termos de competição. Por fim, o capítulo se encerra com as opções de outorga existentes atualmente no marco normativo brasileiro para o modo ferroviário e para as outras modalidades de transporte.

\subsubsection{Titularidade e Propriedade}

Em teoria, a alocação de direitos de propriedade é importante, porque determina os objetivos dos proprietários da firma (pública ou privada) e dos sistemas de monitoramento de desempenho gerencial (Wu \& Nash, 2000). Diante dessas complexas estruturas de mercado, os governos reagiram historicamente em dois caminhos. Alguns países escolheram a propriedade direta do governo para explorar o mercado ferroviário, enquanto outros permitiram a propriedade privada utilizando a regulação para combater as preocupações com o monopólio ou com a competição ruinosa (Waters II, 2007).

Assim, quanto a propriedade, as ferrovias podem ser de três tipos: integralmente privada, integralmente pública ou em um arranjo de meio termo que o público e o privado estabelecem uma parceria, geralmente por contratos de concessão.

\subsubsection{Ferrovias Integralmente Privadas}

Os Estados Unidos são o arquétipo de exploração privada de ferrovias. A exploração ferroviária americana é uma atividade econômica livre desde os primórdios da formação da rede ferroviária nos anos $1820^{6}$. As ferrovias integralmente privadas são caracterizadas, além da natureza jurídica dos seus proprietários, pela liberdade na construção da infraestrutura e operação dos trens. Nesse modelo, geralmente o compartilhamento da malha, quando física e economicamente possível, acontece por acordos voluntários e remunerados entre as firmas privadas (Gómez-Ibáñez, 2016).

As ferrovias podem ser privadas desde a origem, como as seculares ferrovias americanas ou podem ser fruto de recentes privatizações integrais, como a Luoding Railway, privatizada pelo governo chinês, em 2006. Podem transportar exclusivamente carga própria, como a Rio Tinto Railway ou também cargas de terceiros, como a BNSF, além de passageiros. A tabela 2.2 apresenta alguns exemplos:

\footnotetext{
${ }^{6} \mathrm{O}$ histórico americano é tratado em mais detalhes no subitem 3.2
} 
Tabela 2.2 Exemplos de ferrovias integralmente privadas ${ }^{7}$.

\begin{tabular}{lllr}
\hline \multirow{2}{*}{ Ferrovia } & País & \multicolumn{2}{c}{ Características } \\
\cline { 3 - 4 } & & Transporte & Extensão (km) \\
\hline Rio Tinto & Austrália & Minério & 1.700 \\
Luoding & China & PUssageiros & 138 \\
BNSF & EUA & Carga & 52.300 \\
Keio & Japão & Passageiros & 84 \\
\hline
\end{tabular}

Fontes: Rio Tinto (2017); Pittman (2011); BNSF (2017); Keio (2017)

\subsubsection{Ferrovias Integralmente Públicas}

A exploração integralmente pública é, na Europa, o modelo dominante da provisão da infraestrutura ferroviária. O Estado pode gerir a ferrovia por meio de uma empresa pública, uma agência governamental nacional ou local ou mesmo um Ministério (Laurino et al., 2015). A exploração integralmente pública foi um fenômeno iniciado em todo o mundo, entre 1880 e 1910, por meio da nacionalização de empresas privadas ou construção de ramais pelo Estado (Bogart, 2010). A exploração integralmente pública era vista como uma alternativa para se evitar: abusos da exploração monopolista por firmas privadas ou o fechamento de ramais financeiramente deficitários, mas socialmente necessários. Praticamente todos os países do mundo já adotaram esse modelo, mesmo que temporária ou parcialmente em suas redes.

Mesmo os Estados Unidos, arquétipo da exploração privada, constituiu, por exemplo, uma empresa pública, Consolidated Rail Corporation, para explorar alguns ramais ferroviários de carga deficitários, entre 1980 e 1987 (Resor \& Laird, 2013).

Em 2015, Áustria, França, Alemanha, Grã-Bretanha, Hungria, Itália, Espanha, Suécia, Rússia, Turquia, Chile, China, Índia, Japão, Austrália e África do Sul possuíam linhas férreas em seus territórios exploradas integralmente por entidades de natureza pública (Laurino et al., 2015). Esse arranjo foi muito contestado nos anos 1990 devido ao desempenho insuficiente das administrações ferroviárias, profundamente afetadas por falta de competição e transparência e ao mesmo tempo altamente dependentes de subsídios públicos (Nash, 1998; Waters II, 2007). A tabela 2.3 apresenta alguns exemplos de ferrovias integralmente públicas:

\footnotetext{
${ }^{7}$ Cf. LAURINO et al (2015), levantamento global em 20 países sobre a regulação da exploração de 817 mil km de ferrovias evidencia que $37 \%$ das ferrovias são exploradas por empresas integralmente privadas e $11 \%$ por Parcerias Público Privadas ou empresas privadas em regime de outorga com termo.

${ }^{8}$ Em 2006, tornou-se a primeira e única ferrovia $100 \%$ privada da China (Pittman, 2011)
} 
Tabela 2.3 Exemplos de ferrovias integralmente públicas

\begin{tabular}{lllr}
\hline \multirow{2}{*}{ Ferrovia } & País & \multicolumn{2}{c}{ Características } \\
\cline { 3 - 4 } & & Transporte & Extensão (km) \\
\hline Deutschebahn & Alemanha & Carga e passageiros & 33.300 \\
Indian Railways & Índia & Carga e Passageiros & 92.081 \\
Amtrak & EUA & Passageiros & 1.170 \\
RZD & Rússia & Cargas e passageiros & 81.000 \\
\hline
\end{tabular}

Fontes: DB (2017); Indian Railways (2017); Amtrak (2016); RZD (2017)

\subsubsection{Ferrovias de Titularidade Pública e Gestão Privada}

A solução dos países que não mais conseguiam subsidiar suas ferrovias públicas foi transferilas para a iniciativa privada, geralmente por meio de contratos de concessão com termo. Assim, a exploração em parcerias, geralmente mantém a titularidade do ativo como pública, mas permite sua gestão em termos privados. A depender da situação econômica da ferrovia, a firma privada pode tanto remunerar o Estado, geralmente por meio de arrendamentos anuais, ou ser remunerada pelo Estado por meio de subsídios às tarifas ou pagamentos diretos. Esse arranjo, em 2015, era empregado, por exemplo, por Austrália, Brasil, França, Espanha, Inglaterra e México (Laurino et al., 2015). A tabela 2.4 apresenta alguns exemplos:

Tabela 2.4 Exemplos de ferrovias de titularidade públicas e gestão privada

\begin{tabular}{lllr}
\hline \multirow{2}{*}{ Ferrovia } & País & \multicolumn{2}{c}{ Características } \\
\cline { 3 - 4 } & & Transporte & Extensão $(\mathrm{km})$ \\
\hline Rumo-ALL & Brasil & Carga & 11.986 \\
FCA & Brasil & Carga & 7.223 \\
Transnordestina & Brasil & Carga & 4.295 \\
Ferrocarril del & México & Carga & 2.600 \\
Sureste & & & \\
\hline
\end{tabular}

Fontes: ANTT (2017), Campos (2001)

\subsubsection{Organização e Exploração}

Os primeiros subitens apresentam a condição monopolista ferroviária por dois enfoques, a agregação geográfica e a agregação integralmente vertical. Os três subitens seguintes tratam das estratégias de mitigação do monopólio: a segregação geográfica, a segregação vertical, contábil ou organizacional e a segregação horizontal, institucional ou open access.

\subsubsection{Agregação Geográfica}

O sistema de agregação geográfica foi a solução adotada por diversos países ${ }^{10}$ a fim de, supostamente, aumentarem a eficiência das ferrovias (Pittman, 2011). A justificativa para

\footnotetext{
${ }^{9}$ Amtrak também opera na malha de outras ferrovias de carga e passageiros em um total de $34.000 \mathrm{~km}$ (Amtrak, 2016).
} 
aglutinar todas as ferrovias em uma só empresa são os ganhos de escala e de coordenação da empresa monopolista (Jupe, 2009). Como desvantagens a agregação geográfica expõe os usuários a maiores riscos de discriminação (Pittman, 2011). Por causa disso, geralmente, só é permitida quando praticada por empresas estatais.

\subsubsection{Agregação Integralmente Vertical ${ }^{11}$}

$\mathrm{Na}$ agregação integralmente vertical, uma só firma é responsável pela exploração da infraestrutura (manutenção, sinalização, segurança) dos trilhos e também pela operação dos trens. Essa, aliás, é a solução tradicional ou histórica de organização das ferrovias no mundo. Somente no fim dos anos 1980 países da Europa passaram a adotar outras soluções de organização, a ver nos subitens seguintes. Os países das Américas e da Ásia continuam adotando a agregação integralmente vertical tanto pelas empresas privadas quanto pelos órgãos ou entidades estatais, a exemplo dos EUA, Canadá, México, Argentina, Brasil, China e Japão. Como vantagens também permite ganhos de escala e coordenação. Pode ser com ou sem exclusividade de tráfego.

A agregação vertical com exclusividade de tráfego é mais comum em malhas isoladas onde não é possível a conexão física entre ferrovias. No Brasil, esse modelo existiu, por exemplo, nas seguintes ferrovias, apresentadas na tabela 2.5:

Tabela 2.5 Ferrovias brasileiras isoladas

\begin{tabular}{|c|c|c|c|c|}
\hline Ferrovia & Extensão & Bitola & Carga & UF \\
\hline Jari & $68 \mathrm{~km}$ & $1,6 \mathrm{~m}$ & $\begin{array}{l}\text { Em } 1997 \text { transportou 1,1 milhões de toneladas de } \\
\text { mercadorias (bauxita, madeira cultivada } \mathrm{e} \text { brita, } \\
\text { equivalente a } 32 \text { milhões de TKU }\end{array}$ & Pará \\
\hline Trombetas & $35 \mathrm{~km}$ & $1,0 \mathrm{~m}$ & $\begin{array}{l}1997 \text { transportou } 9,6 \text { milhões de toneladas de } \\
\text { mercadorias (bauxita), equivalente a } 288 \text { milhões de } \\
\text { TKU, }\end{array}$ & Pará \\
\hline $\begin{array}{l}\text { Tereza } \\
\text { Cristina }\end{array}$ & $164 \mathrm{~km}$ & $1,0 \mathrm{~m}$ & $\begin{array}{l}\text { Em 2014, transportou } 288 \text { de TKU, notadamente carvão } \\
\text { mineral. }\end{array}$ & $\begin{array}{l}\text { Santa } \\
\text { Catarina }\end{array}$ \\
\hline
\end{tabular}

Na agregação vertical sem exclusividade de tráfego, a firma ferroviária permite que trens de outra firma ferroviária acesse sua infraestrutura. $\mathrm{O}$ acesso de terceiros tanto pode ser realizado em razão de acordos voluntários entre as firmas, como pode ser imposto pela autoridade regulatória.

\footnotetext{
${ }^{10}$ Exemplos: Reino Unido, em 1947, criou a Brithish Railways; Brasil, em 1957, criou a RFFSA; Reino Unido, em 2002, criou a Network Rail; Argentina em 2015 criou a Ferrocarriles Argentinos Sociedad del Estado.

${ }^{11}$ Também chamada system competition (Pittman, 2011)
} 
Na verticalização, a aglutinação de funções reduz o problema de custos de transação e de coordenação. Todavia, nessa condição, a firma pode tender a discriminar a entrada de outras firmas operadoras de trens. Na reforma e privatização ferroviária do Brasil de 1995-98, o regulamento da época previu que as administrações ferroviárias deveriam permitir o direito de passagem ou o tráfego mútuo em suas malhas por outras administrações ferroviárias. Como mitigação dos efeitos colaterais da agregação vertical, esse modelo geralmente é utilizado com a segregação geográfica, a ser descrita no subitem seguinte.

\subsubsection{Segregação Geográfica}

Na segregação geográfica o total da malha ferroviária é devido em diferentes frações a fim de que a mesma firma não possua todas as alternativas de conexão entre os principais nós da rede. Desse modo, em teoria, fica preservado o poder de concorrência entre as ferrovias em operação na malha. A não ser que as ferrovias combinem preços, uma estaria impedida de abusar de seu monopólio natural, pois, haveria outra capaz de executar o transporte entre o mesmo par de origem e destino, na melhor hipótese de concorrência, ou a pelo menos a um dos nós do arco origem e destino, na segunda melhor hipótese de concorrência (Pittman, 2004; Friebel et al., 2007).

\subsubsection{Segregação Vertical ou Contábil ${ }^{12}$}

A estratégia de quebra do monopólio natural da firma ferroviária na União Europeia baseia-se em três pilares: desagregação da infraestrutura das operações, criação de instituições reguladoras independentes para as linhas férreas e abertura do acesso aos mercados ferroviários nacionais para concorrentes, third-party access (Friebel et al., 2007). A solução de segregação mais branda da União Europeia é a segregação vertical ou contábil (Takasaki, 2014). Nessa solução a mesma firma pode operar os trens e administrar os trilhos, desde que o faça com duas contabilidades separadas, de maneira que os órgãos de controle e regulação possam ter conhecimento sobre a formação dos preços das tarifas aos usuários e às demais operadoras, que acessam a malha da firma hospedeira. Esse também é o modelo da primeira diretriz europeia de 1991.

\subsubsection{Segregação Horizontal ${ }^{13}$ ou Institucional ${ }^{14}$ ou Open Access}

A segregação integralmente horizontal é aquela em que não é permitido à empresa que explora a infraestrutura operar os trens. Essa solução tem como vantagem teórica o

\footnotetext{
12 Pitman (2005) intitula esse modelo por "acesso vertical” (vertical access).

${ }^{13}$ Pitman (2005) intitula esse modelo por "separação vertical"

${ }^{14}$ Takasaki (2014)
} 
desincentivo a discriminação de novos operadores ferroviários entrantes no mercado (Pittman, 2011). O modelo em open access tem como desvantagens: aumento dos custos; falta de coordenação; perda de economia de escala e escopo; deficiência de planejamento e investimento de longo prazo. Segundo Mizutani e Uranish (2013) o open access tende a baixar os custos em malhas pouco trafegadas e aumentar os custos em malhas muito trafegadas.

\subsubsection{Competição e Concorrência}

A questão chave na organização do modo de transporte ferroviário é a obtenção da concorrência, pois, em ambientes competitivos, até mesmo monopólios naturais setoriais podem perder seus poderes monopolistas (Pittman, 2011). A promoção da concorrência é altamente desejável quando a concorrência intermodal está ausente, uma vez que a competição entre as firmas oferece fortes incentivos para aumentar a eficiência (Pittman, 2007). Há basicamente duas formas de produzir competição entre ferrovias, a competição pelo acesso a infraestrutura, modelo europeu, ou a competição por rotas, modelo americano e asiático.

\subsubsection{Competição pelo acesso a infraestrutura}

A União Europeia, a partir de 1991, passou a recomendar que a contabilidade das empresas ferroviárias fosse separada entre operação dos trens e manutenção da infraestrutura, no entanto, permitia a competição no mercado de operação de trens pela empresa de infraestrutura ferroviária (Pittman, 2004). A partir de 2001, a União Europeia passou a reforçar o modelo de open access no qual a exploradora da infraestrutura estaria impedida de operar os serviços de trens (Pittman, 2004). No modelo mais horizontal (open access), uma empresa é responsável pela manutenção da infraestrutura em regime de monopólio enquanto a oferta dos serviços de transportes de carga e/ou passageiros é realizada em regime de concorrência.

Esse modelo, no entanto, na prática não tem alcançado os resultados esperados. Nos países que abriram sua infraestrutura ferroviária para a entrada por operadores ferroviários independentes não foi criada muita concorrência. Em alguns países, parte do problema foi devido à recusa dos exploradores da infraestrutura de conceder licenças a empresas que buscam servir como operadores de trem independentes (Friebel et al., 2007). Todavia, alguns autores consideram que o próprio modelo de segregação horizontal não produz competição (Tomeš, 2017). Outros autores apenas demonstram que a privatização das ferrovias no Reino 
Unido, que adotou o open access foi malsucedida, sem, no entanto, associa-la diretamente ao modelo em si (Jupe, 2009; Bowman, 2015).

\subsubsection{Competição por rotas}

Nos Estados Unidos, Canadá, México, Brasil ${ }^{15}$, China e Japão a principal estratégia para mitigar ou mesmo acabar com os efeitos do monopólio natural da firma ferroviária é a segregação geográfica associada a agregação vertical e são considerados casos de sucesso (Resor \& Laird, 2013). Em teoria, a melhor opção de competição, ocorre quando a malha é suficientemente grande, pois, diferentes firmas ferroviárias independentes poderiam competir pelos mesmos pares de Origem e Destino (Friebel et al., 2007; Pittman 2004). No entanto, a opção mais comum de competição nos mercados que adotam a agregação integralmente vertical ocorre quando apenas a origem ou o destino é servido por mais de uma ferrovia independente (Friebel et al., 2007; Pittman 2004).

A Austrália, por sua vez adota as duas principais estratégias de competição, pois tanto permite a exploração integralmente verticalizada como nos Estados Unidos, quanto permite o chamado open access em que a operação dos trens e manutenção dos trilhos são executados por empresas separadas (Merkert \& Hensher, 2014).

A tabela 2.6 resume as possibilidades de organização das empresas ferroviárias. No modelo mais verticalizado, a mesma empresa A, é responsável tanto pela manutenção da infraestrutura (trilhos, sinalização, etc) quanto pela operação dos serviços de transporte de cargas e/ou passageiros em regime de monopólio, portanto, sem competição na sua malha. É possível ainda que exista verticalização apenas no mercado ou de carga ou de passageiros, sendo possível que a empresa que explora a infraestrutura compita com outras empresas em um desse mercados (carga ou passageiro), como visto na segunda e terceira coluna da tabela 2.6.

Tabela 2.6 Grau de separação entre exploração de infraestrutura e serviços de transportes

\begin{tabular}{|c|c|c|c|c|}
\hline & \multirow{2}{*}{ Vertical Exclusivo } & \multicolumn{2}{|c|}{ Vertical Parcial } & \multirow{2}{*}{ Horizontal } \\
\hline & & Cargas & Passageiros & \\
\hline $\begin{array}{l}\text { Operação dos trens } \\
\text { (Passageiros) }\end{array}$ & A & A e/ou B, C, ... & A & B e/ou C, ... \\
\hline $\begin{array}{l}\text { Operação dos trens } \\
\text { (Carga) }\end{array}$ & A & A & A e/ou B, C, ... & B e/ou C, ... \\
\hline $\begin{array}{l}\text { Manutenção da } \\
\text { Infraestrutura } \\
\text { (Trilhos) }\end{array}$ & A & A & A & A \\
\hline
\end{tabular}

Fonte: Laurino (2015) com adaptações.

\footnotetext{
${ }^{15}$ Esse princípio adotado nos anos 1995-98 foi perdido ao longo dos anos em razão da permissão de continuas aglutinações das ferrovias, que resultaram na formação de oligopólios sem competição por rotas.
} 
Observa-se que, para o tráfego na rede, não existe diferença no modelo de integração vertical com compartilhamento de rede para o modelo de segregação vertical ou contábil. Em ambos, a firma $\mathrm{A}$, que mantém a infraestrutura, permite o trânsito de uma firma $\mathrm{B}$ visitante. A diferença concreta entre esses modelos é que no de agregação vertical, a firma visitante B é, necessariamente, uma firma responsável pela manutenção da infraestrutura de sua rede, onde A também poderá operar. No modelo de segregação vertical, a firma visitante B pode ser exclusivamente uma firma operadora, que não tem em seu negócio a preocupação com a manutenção da infraestrutura. Essa diferença, contudo, não é pequena. Há muito mais incentivo econômico para o apropriado compartilhamento dos custos de manutenção quando B também exerce a atividade de manutenção da infraestrutura em sua rede.

\subsubsection{Concessão e Outorga}

Barreiras econômicas a entradas e saídas de uma firma no mercado são entraves ao desenvolvimento de mercados contestáveis, em que a crença da entrada de um novo player impede que a firma estabelecida explore seu poder monopolista ou oligopolista (Baumol et al., 1983). No Brasil, além das já elevadas barreiras econômicas naturais, que dificultam o estabelecimento da contestabilidade do mercado, os players do setor ferroviário usufruem, ao menos, em teoria, de barreiras jurídicas a entradas de novas firmas. A remoção das barreiras jurídicas poderia contribuir para a maior competitividade do setor ferroviário brasileiro.

\subsubsection{Marcos da Legislação Ferroviária}

Embora a Constituição Federal não tenha declarado que a exploração do transporte ferroviário é um serviço público, esse entendimento consolidou-se na legislação infraconstitucional, de maneira que, atualmente, não há espaço para a livre iniciativa privada em termos da exploração do transporte ferroviário.

Diferentemente dos EUA, em que, qualquer firma que esteja disposta a construir uma ferrovia pode solicitar uma licença do Surface Transportation Board (Sampaio \& Daychoum, 2017), no Brasil, a iniciativa privada só pode atuar nos casos em que o Poder Público tomar a iniciativa da outorga, nos exatos termos da legislação infraconstitucional, mais restritiva que a própria Constituição Federal, como pode ser observado nas hipóteses de outorgas resumidas na tabela 2.7:

Tabela 2.7 Formas de outorga do transporte ferroviário no Brasil

\begin{tabular}{lll}
\hline Outorga & Dispositivo & Atividade \\
\hline autorização, & $\mathrm{CF}$, art. $21, \mathrm{XII}, \mathrm{d}$. & serviços de transporte ferroviário entre portos brasileiros e \\
concessão ou & & fronteiras nacionais, ou que transponham os limites de Estado ou \\
permissão. & Território
\end{tabular}




\begin{tabular}{|c|c|c|}
\hline Outorga & Dispositivo & Atividade \\
\hline autorização & $\begin{array}{l}\mathrm{CF}, \text { art. } 170, \\
\text { parágrafo único }\end{array}$ & $\begin{array}{l}\text { é assegurado a todos o livre exercício de qualquer atividade } \\
\text { econômica, independentemente de autorização de órgãos públicos, } \\
\text { salvo nos casos previstos em lei }\end{array}$ \\
\hline $\begin{array}{l}\text { concessão ou } \\
\text { permissão }\end{array}$ & $\mathrm{CF}$, art. 175 . & prestação de serviços públicos \\
\hline concessão & $\begin{array}{l}\text { Lei } \mathrm{n}^{\circ} 8.987, \text { de } 1995, \\
\text { art. } 2^{\circ}, \text { II }\end{array}$ & $\begin{array}{l}\text { a delegação de sua prestação, feita pelo poder concedente, mediante } \\
\text { licitação, na modalidade de concorrência, à pessoa jurídica ou } \\
\text { consórcio de empresas que demonstre capacidade para seu } \\
\text { desempenho, por sua conta e risco e por prazo determinado }\end{array}$ \\
\hline $\begin{array}{l}\text { concessão ou } \\
\text { permissão }\end{array}$ & $\begin{array}{l}\text { Lei } n^{\circ} 9.074, \text { de } 1995 \\
\text { art. } 1^{\circ}, \text { IV }\end{array}$ & vias federais, precedidas ou não da execução de obra pública \\
\hline concessão & $\begin{array}{l}\text { Lei } \mathrm{n}^{\circ} 10.233, \text { de } \\
2001 \text {, art. 14, I, a }\end{array}$ & $\begin{array}{l}\text { exploração das ferrovias que compõem a infraestrutura do Sistema } \\
\text { Nacional de Viação }\end{array}$ \\
\hline concessão & $\begin{array}{l}\text { Lei } \mathrm{n}^{\circ} 10.233, \text { de } \\
2001, \text { art. } 14, \mathrm{I}, \mathrm{b}\end{array}$ & $\begin{array}{l}\text { transporte ferroviário de passageiros e cargas associado à } \\
\text { exploração da infraestrutura ferroviária }\end{array}$ \\
\hline permissão & $\begin{array}{l}\text { Lei } \mathrm{n}^{\mathrm{o}} 10.233 \text {, de } \\
2001 \text {, art. } 14, \mathrm{IV}, \mathrm{b}\end{array}$ & $\begin{array}{l}\text { transporte ferroviário regular de passageiros não associado à } \\
\text { infraestrutura }\end{array}$ \\
\hline autorização & $\begin{array}{l}\text { Lei } \mathrm{n}^{\circ} 10.233 \text {, de } \\
\text { 2001, art. 14, III, f }\end{array}$ & $\begin{array}{l}\text { transporte ferroviário não regular de passageiros, não associado à } \\
\text { exploração da infraestrutura }\end{array}$ \\
\hline autorização & $\begin{array}{l}\text { Lei } \mathrm{n}^{\mathrm{o}} 10.233 \text {, de } \\
2001 \text {, art. } 14 \text {, III, i }\end{array}$ & $\begin{array}{l}\text { transporte ferroviário de cargas não associado à exploração da } \\
\text { infraestrutura, por operador ferroviário independente }\end{array}$ \\
\hline
\end{tabular}

A legislação brasileira, no campo da outorga do transporte ferroviário, seguiu o modelo europeu - de competição pela infraestrutura -, muito embora a prática das outorgas dos anos 1990 tenha seguido o modelo de exploração adotado nos EUA, de competição pelas rotas de origem e destino do transporte. Há no campo normativo uma clara divergência entre o que foi estabelecido na prática das concessionárias ferroviárias e o que está atualmente positivado na legislação. Possivelmente, esse descasamento possa, em parte, explicar o pequeno interesse de firmas brasileiras pela atividade de Operador Ferroviário Independente.

Outra consequência dessa restrição meramente jurídica, é que no atual marco normativo não há incentivos a competição entre as firmas ferroviárias, em razão da entrada de novos players privados. Mesmo quando há interesse de firmas nacionais ou estrangeiras pela exploração de ferrovias brasileiras (SEP, 2016; Pelegi, 2017; Otta, 2017; Senado, 2017) os investimentos não são realizados em razão das dificuldades da União em preparar leilões de outorga.

A restrição ao investimento livre da iniciativa privada não se repete em outros setores da infraestrutura de transporte como, por exemplo, o aéreo, o portuário e o dutoviário. 


\subsubsection{Marcos de outros Modos de Transporte}

A legislação aeroportuária, positivada no Código Brasileiro de Aeronáutica, Lei no 7.565, de 1986, previu a existência de aeródromos privados construídos - com prévia autorização da autoridade aeronáutica (art. 34), mantidos e operados por seus proprietários, obedecidas as instruções, normas e planos da autoridade aeronáutica (art. 35).

A legislação sobre a política energética, Lei n ${ }^{\circ}$ 9.478, de 1997, quando tratou do transporte de petróleo, seus derivados e gás natural, estabeleceu que qualquer firma, constituída sob as leis brasileiras, com sede e administração no País, atuante nas atividades de pesquisa e lavra, refinação, importação, exportação ou transporte, poderá receber autorização da Agência Nacional do Petróleo para construir instalações e efetuar qualquer modalidade de transporte de petróleo, seus derivados e gás natural, seja para suprimento interno ou para importação e exportação (art. $4^{\circ}$ e $5^{\circ} \mathrm{c} / \mathrm{c}$ art. 56).

Note-se que a infraestrutura ferroviária e dutoviária têm as mesmas características de indústrias de rede lineares fechadas. Do ponto de vista econômico, não estão sujeitas ao efeito carona dos usuários, necessitam de altos custos fixos (Eller et al., 2011), e são geralmente vinculadas a indústrias específicas. Todavia, o transporte ferroviário, no plano infraconstitucional, foi tratado como serviço público e o transporte dutoviário, como atividade econômica livre.

A legislação portuária recentemente foi modernizada pela Lei ${ }^{\circ} 12.815$, de 2013 , que criou a possibilidade de a iniciativa privada explorar instalações portuárias, para o transporte de carga própria ou de terceiros. Segundo essa norma, serão exploradas mediante autorização, precedida de chamada ou anúncio públicos e, quando for o caso, processo seletivo público, as instalações portuárias localizadas fora da área do porto organizado. A autorização será formalizada por meio de contrato de adesão, com prazo de até 25 (vinte e cinco) anos, prorrogável por períodos sucessivos, desde que: a atividade portuária seja mantida; e o autorizatário promova os investimentos necessários para a expansão e modernização das instalações portuárias.

Há na legislação um descompasso entre as liberdades à iniciativa privada em setores da infraestrutura dos transportes. Enquanto há maiores liberdades para a provisão de infraestruturas aeronáuticas, dutoviárias e portuárias, a infraestrutura ferroviária tem o absoluto monopólio da iniciativa pública. 


\subsubsection{Aquisição de domínios}

Se houvesse maior liberdade à iniciativa do empreendimento ferroviário privado, como há em outros países benchmarks do setor, a exemplo de EUA e Japão, e como também há em outros setores da infraestrutura de transportes no Brasil, haveria uma questão crucial a ser enfrentada. Como a empresa privada adquiria as terras necessárias ao empreendimento ferroviário?

A primeira alternativa, a mais liberal e preferível, seria pelos acordos voluntários de vontade. Os próprios proprietários das terras se juntariam para formar a firma ferroviária que beneficiaria seu território, a exemplo da prática adotada nos EUA, no século XIX (Silva, 1904) e Japão, atualmente (Suzuki et al., 2015).

A segunda alternativa, mais estatal e complementar à primeira, seria por incluir a firma ferroviária privada no rol dos legitimados ativos para promover a desapropriação de terras, mediante autorização expressa constante em lei ou contrato. Aliás, em parte, essa solução já vigeu no Brasil no governo Dilma Rousseff, que editou a Medida Provisória (MPV) n ${ }^{\mathrm{o}} 700$, de 2015 .

Segundo a exposição de motivos, a MPV nº 700, de 2015, objetivava estimular o investimento privado em infraestrutura no país, a partir da desburocratização da legislação relativa à desapropriação por utilidade pública, do que se extrai do seguinte excerto de Barbosa et al. (2015):

Os processos de desapropriação são entraves para soluções de infraestrutura, uma vez que são excessivamente morosos e demandam procedimentos, geralmente, repetitivos e desnecessários. A atualização desse marco legal aos novos modelos de execução de obras, possibilitando a inclusão de concessionários, autorizatários e contratados na condução do processo de desapropriação, vai ao encontro da nova formatação de contratos públicos garantindo maior celeridade e segurança aos processos.

[...] a urgência da presente medida se coaduna com outros esforços do governo federal para estimular o investimento privado em infraestrutura no país, reduzindo etapas e simplificando procedimentos desapropriatórios considerados dificultadores às soluções de infraestrutura [...]

A MPV n 700, de 2015, beneficiaria apenas em parte a exploração da infraestrutura ferroviária, pois, segundo o restante da legislação infraconstitucional, no Brasil, não existe hipótese da construção de ferrovias meramente autorizadas pelo poder público como ocorre nos EUA e Japão. Ainda assim, os atuais concessionários poderiam ter se beneficiado do novo instrumento. Todavia, no meio da crise política vivida nos últimos meses do governo Dilma 
Rousseff, a MPV n⿳ 700, de 2015, não foi apreciada pelo Congresso Nacional, tendo perdido a sua eficácia por decurso de prazo.

\subsubsection{Escolha dos Vencedores}

A legislação específica dos transportes terrestres, Lei $\mathrm{n}^{\circ}$ 10.233, de 2001, prevê, expressamente, a menor tarifa e a melhor oferta pela outorga, considerada isolada ou conjugadamente, como critérios para o julgamento da licitação de concessão, assegurado a prestação de serviços adequados (art. 34-A, $\S 2^{\circ}$, IV). Outros critérios de escolha são previstos expressamente em outras legislações de transporte, como, por exemplo, a maior capacidade de movimentação ou o menor tempo de movimentação de carga (Lei n ${ }^{\circ} 12.815$, de 2013, Lei dos Portos). 


\section{HISTÓRICO INTERNACIONAL}

O desenvolvimento do setor ferroviário mundo afora aconteceu, notadamente, baseado em duas estratégias distintas: uma liberal, baseada nas forças do mercado, e outra estatal, baseada na força do planejamento e gestão centralizada pelo governo. Essas estratégias foram aplicadas em sequência ou em paralelo e alcançaram resultados bem distintos a depender das condições específicas de cada país, mas, em geral, o desenvolvimento ferroviário passou por três ou quatro fases: a primeira de crescimento, geralmente com predominância de agentes econômicos privados; a segunda de estatização da indústria, por meio da nacionalização de linhas e constrições regulatórias; a terceira de privatização ou desregulamentação da indústria e em, alguns casos, houve uma quarta fase de retorno do estatismo, por meio de constrições regulatórias e subsídios. Para ilustrar esse desenvolvimento as seções seguintes apresentarão o desenvolvimento do mercado ferroviário do Reino Unido, dos Estados Unidos, da China e do Brasil.

O histórico do Reino Unido é citado em razão da significativa influência do modelo de acesso aberto (open access) à rede ferroviária, adotado por aquele país europeu, nas diretrizes do governo federal brasileiro, na administração Dilma Rousseff (2011-2016), além de ser o benchmak precursor da atividade. Os Estados Unidos da América foram escolhidos por ser benchmark do setor ferroviário de cargas, pois têm a maior malha do planeta e alcançaram o crescimento mais significativo no primeiro século da história ferroviária. A China, por sua vez, também é benchmark do setor ferroviário, principalmente no transporte de passageiros, pois tem a maior malha de trens de alta velocidade do mundo e alcançou crescimento substancial nos últimos 20 anos.

\subsection{HISTÓRICO FERROVIÁRIO BRITÂNICO}

Segundo Blanning (2007), a Inglaterra foi a nação precursora dos investimentos privados na provisão de infraestrutura de transportes terrestres. Em 1695, o mercado obteve segurança jurídica para investir na construção e manutenção de estradas pavimentadas, por meio de Acts of Parliament que autorizavam a cobrança privada de tarifas sobre o tráfego ao longo de certa extensão das estradas. No século XVIII, os Turnpike Acts, do Parlamento inglês, revolucionaram a provisão de infraestrutura rodoviária.

Naquele século, cresceu a malha e reduziram-se, substancialmente, os tempos de viagem. Em contraste, na mesma época, na Europa continental a infraestrutura rodoviária era precaríssima. As únicas boas estradas na Europa continental eram aquelas que conectavam as fortificações e 
os palácios de interesse das Coroas. A provisão de infraestrutura tinha na Europa continental motivação política, para defesa do Estado ou satisfação do Rei. Na Inglaterra, por sua vez, o interesse econômico era predominante na definição dos traçados das novas estradas pavimentadas (Blanning, 2007).

\subsubsection{Livre para Trilhar}

A experiência de parcerias privadas inglesas no mercado rodoviário foi adaptada. Inicialmente no mercado de provisão de canais de navegação interior e na sequência foi também incorporada ao mercado ferroviário, aberto nos anos 1820, na própria Inglaterra, com o surgimento dos caminhos de ferro e da locomotiva a vapor ${ }^{16}$. O exemplo inglês de provisão de infraestrutura de transporte privada repercutiu em todos os principais países do mundo, todavia com intensidades e características próprias. A maior parte da rede ferroviária mundial foi construída na segunda parte do século XIX e a primeira metade do século XX (Laurino et al., 2015).

Segundo Silva (1904), nos primórdios da indústria ferroviária acreditava-se que o tráfego nas estradas de ferro, dar-se-ia como nas estradas de rodagem e canais de navegação, i.e., uma vez construída a infraestrutura, admitir-se-ia o tráfego de todos os trens que os respectivos proprietários quisessem pôr em circulação, como genuínas vias públicas, suscetíveis à livre concorrência de tráfego de todos os interessados, satisfeitas as legislações de segurança. Contudo, isso logo se mostrou inviável, pois, nos primórdios do modo ferroviário haveria uma forte necessidade de coordenação da firma entre as atividades de transporte, manutenção, segurança e gestão da linha, que não seria viável, senão em monopólio natural, industrial e legal (Silva, 1904).

Para Silva (1904), a abundância de capitais, o comportamento especulativo das firmas, a estabilidade do regime de liberdades políticas e a tradição de não intervenção do Estado nos negócios da iniciativa privada permitiram que na Inglaterra as firmas ferroviárias privadas agissem em completa liberdade até 1844. Até então, as concessões foram sempre feitas em regime de perpetuidade, sem privilégio de qualidade alguma.

Em 1845, havia quase 700 linhas separadas, com extensão média não superior a $30 \mathrm{~km}$, em um sem número de bitolas ${ }^{17}$. Em nenhum país do mundo houve a adoção de tantas bitolas diferentes como na Inglaterra. A grande quantidade de bitolas dificultava em excesso o

\footnotetext{
${ }^{16}$ Em 1821 foi criada a Stockton \& Darlington Railway Co., construtora e operadora da primeira estrada de ferro inglesa e mundial, inaugurada em 1825 (Daychoum \& Sampaio, 2017)

${ }^{17}$ Bitola é a medida de espaçamento entre as faces internas dos boletos dos trilhos. Quanto maior a bitola, em teoria, maiores são a velocidade operacional e a capacidade de transporte máxima dos trens. Quanto menor a bitola, menores são os custos de construção das linhas (Santos, 2011).
} 
tráfego, impedindo a mutualidade de circulação dos trens, gerando a primeira crise do sistema ferroviário. O Parlamento, em reação, editou o Gauges Act, de 1846, que obrigou a unificação do sistema ferroviário do Reino Unido na bitola de $1435 \mathrm{~mm}^{18}$ (Silva, 1904).

A iniciativa parlamentar de 1846 contribuiu para um processo de fusões e aquisições das linhas férreas. As menores linhas foram sendo adquiridas pelas maiores, a concorrência predatória começou a causar incômodos reverberados no Parlamento, que passou a regular a indústria editando diversos atos sobre o tema durante o século XIX. A preocupação preponderante do Parlamento era a instituição de tráfego mútuo ${ }^{19}$, tendo em vista os interesses do público e o das pequenas linhas, bem como, impedir o abuso de tarifas preferenciais. As concessões ferroviárias britânicas além de serem perpétuas, não tinham seus traçados definidos pelo Estado, o investidor privado era quem definia os pontos de passagem, por sua conta e risco (Silva, 1904).

Após a aprovação das concessões no Parlamento, o Board of Trade regulava o mercado, arbitrando os conflitos decorrentes das firmas ferroviárias, além da segurança do tráfego. Em 1889 a Inglaterra ${ }^{20}$ possuía $24.221 \mathrm{~km}$ de linhas férreas, sendo que $15.992 \mathrm{~km}$ já eram duplicadas (Silva, 1904).

A ferrovia exclusivamente privada foi o paradigma dominante na Inglaterra, no entanto, a liberdade não era absoluta no Reino Unido e muito rara no resto do mundo. A incapacidade dos Estados Nacionais de lidarem, apropriadamente, com os efeitos da concorrência ferroviária (externalidades e falhas de mercado) nas demais indústrias, levou a nacionalização das ferrovias no mundo a fora, com raras exceções, como nos Estados Unidos, Canadá e Reino Unido (Silva, 1904). Por volta de 1910, aproximadamente 10\% das estradas de ferro do mundo já haviam sido nacionalizadas e $22 \%$ já haviam sido construídas pelo Estado (Bogart, 2010). Os britânicos resistiram ao lobby do estatismo até 1921 quando editaram o Railways Act.

Segundo Acworth (1923), no fim de 1921 havia 214 companhias ferroviárias independentes na Grã-Bretanha. Por força do Railways Act, de 1921, 121 dessas ferrovias seriam agrupadas em quatro firmas e as 93 restantes seriam divididas nas seguintes categorias:

a. Empresas pertencentes em conjunto a duas ou mais empresas, e. g. Cheshire Lines;

b. Estradas de ferro leves sem importância, principalmente em bitola estreita;

\footnotetext{
${ }^{18}$ Essa medida foi, posteriormente, adotada internacionalmente como padrão de bitola, embora a Irlanda, membro do Reino Unido, não a tenha adotado, preferindo a bitola de $1600 \mathrm{~mm}$.

${ }^{19}$ O termo tráfego mútuo em Silva (1904) não tem, necessariamente, o mesmo sentido utilizado atualmente, possivelmente significaria direito de passagem nos dias atuais.

${ }^{20}$ Nesse cômputo estão incluídos os ramais do país de Gales.
} 
c. Ferrovias urbanas e suburbanas, principalmente eletrificadas e confinadas ao tráfego de passageiros, e. g. metropolitano de Londres e Túnel de Mersey; e

d. Empresas com ferrovias ainda não construídas ou abandonadas.

As quatro ferrovias principais criadas pelo Railways Act, de 1921, foram: Souther Railway, Great Western Railway; London, Midland and Scottish Raiway; e London and North Eastern Railway, conhecidas como Big Four. Entre as alegações principais para a reorganização da rede ferroviária britânica estava o ganho de cooperação observado durante a primeira Guerra Mundial (1914-1918). Nesse período, as ferrovias britânicas operaram como uma só empresa, administrada pelo governo (Acworth, 1923). No entanto, para Shaw et al. (1998), o Railways Act, de 1921, visava a eliminação da competição por passageiros e a formação de monopólios. Duas evidências nesse sentido podem ser observadas no trabalho de Acworth (1923). Primeiro, embora, o governo tivesse previsto que as aquisições e aglutinações poderiam ser pagas em dinheiro ou em ações, praticamente não houve pagamento em dinheiro. Os proprietários das firmas menores voluntariamente aceitaram ações das novas grandes firmas. A segunda evidência é que poucos foram os casos em que foi preciso fazer mão da arbitragem estatal para a formação das novas firmas. A maioria das firmas fechou arranjos voluntários de aglutinação antes que se iniciassem os prazos de aglutinações compulsórias arbitrados pelo Estado.

As ferrovias britânicas somente foram estatizadas com o Transport Act, de 1947. Mais uma vez justificado pelos ganhos de coordenação ${ }^{21}$ decorrentes da unificação observada na Segunda Guerra Mundial (1939-1945), o Parlamento britânico decidiu substituir as falhas do mercado pela criação de um monopólio, dessa vez estatal.

Segundo Walker (1948), o Transport Act, de 1947, idealizava que o Estado exploraria transporte de longa distância por monopólio público do modo ferroviário, enquanto o transporte de curta distância remanesceria em regime de competição privada por meio do modo rodoviário. Em 1948, o Reino Unido aderia a solução adotada na maioria do mundo, a firma ferroviária monopolista nacional, era criada a British Railways, formada pela nacionalização das quatro grandes ferrovias privadas criadas em 1921.

Em 1950, ferrovias na maior parte do mundo eram de propriedade estatal, com poucas exceções como Estados Unidos e Canadá, que permaneceram quase que integralmente de propriedade privada (Resor \& Laird, 2013).

\footnotetext{
${ }^{21}$ Durante a Segunda Guerra Mundial (1939-1945), o governo britânico administrou a rede ferroviária como uma só empresa.
} 


\subsubsection{Déficit Fiscal, de Cargas e de Passageiros}

Se a firma integralmente privada não durou para sempre, a firma integralmente estatal durou pouco no Reino Unido. Devido a já significativa concorrência com a modalidade rodoviária e as deficiências notórias da gestão estatal, a British Railways começou a experimentar crescentes déficits de passageiros, cargas e receitas.

Com a eleição de Margaret Thatcher ao posto de Primeira Ministra do Reino Unido, pelo Partido Conservador, em 1979, intensificaram-se as discussões sobre a reforma do Estado. $\mathrm{Na}$ área dos transportes ferroviários, desejava-se a redução dos crescentes subsídios fornecidos e a promoção de competição. Fundamentado na experiência positiva com a privatização de estatais de gás e telecomunicações a British Railways foi então privatizada em maio de 1996, segundo uma estratégia de segregação de atividades (Jupe, 2009).

\subsubsection{Segregação da Indústria}

Antes mesmo da privatização britânica, em 1996, vigorava na Europa o entendimento de que o monopólio natural ferroviário poderia ser quebrado com a segregação das atividades a exemplo dos setores de telecomunicação e energia. Basicamente, uma firma cuidaria da manutenção da infraestrutura e outra firma cuidaria da operação dos trens. A Suécia foi o primeiro país a aplicar essa teoria ao segregar, em 1988, a Swdish State Railways (SJ) em duas firmas, SJ Operator, com monopólio no transporte de passageiros de longa distância e Banverket Infrastructure Manger, com monopólio da exploração ferroviária (Finger, 2014).

A firma gestora da infraestrutura seria remunerada pela firma gestora da operação, que seria remunerada diretamente pelos clientes, passageiros ou transportadores de cargas.

A União Europeia passou a aplicar o conceito por meio da Diretiva 91/440, recomendando a adoção da segregação das firmas ferroviárias dos países membros (Nash et al., 2011) No Reino Unido a segregação foi uma das mais radicais (Finger, 2014). A privatização de 1996, segundo Jupe (2009) segregou a British Railways em:

- firmas de provisão de manutenção de infraestrutura (INFRACOs);

- firmas de leasing de trens (ROSCOs);

- firmas de operação de trens de passageiros (TOCs);

- firmas de operação de trens de cargas; e

- 1 firma monopolista exploradora da infraestrutura;

$\mathrm{Na}$ teoria desse modelo a firma exploradora da infraestrutura seria remunerada pelas firmas operadoras pelo acesso aos trilhos e sistemas de sinalização e comunicação. As operadoras seriam remuneradas diretamente pelos passageiros e embarcadores de cargas. Esperava-se 
com isso, a introdução de incentivos para o acesso não discriminado das firmas operadoras pelas firmas provedoras de infraestrutura, o aumento da competição no mercado, a redução dos subsídios.

\subsubsection{Incertezas no Modelo}

O resultado, contudo, não foi o esperado. Os subsídios continuaram a ser pagos, o aumento de competição não foi observado, e até mesmo o aumento de passageiros transportados foi atribuído a fatores exógenos à privatização, como aumento dos congestionamentos ferroviários. Em pouco menos de 10 anos o Reino Unido foi obrigado a nacionalizar a Railtrack, firma formada na privatização de 1995. Ficava então criada a Network Rail, estatal britânica responsável pela exploração dos trilhos, em regime de monopólio (Jupe \& Crompton, 2006; Jupe, 2009)

\subsection{HISTÓRICO FERROVIÁRIO AMERICANO}

Nenhum país do mundo tem sua história tão atrelada ao desenvolvimento ferroviário como os Estados Unidos da América. O transporte ferroviário criado na Inglaterra passou por grandes melhorias nos EUA. Foi na américa que o telégrafo foi definitivamente adotado para proteger e regular o movimento dos trens, bem como foram padronizados os fusos-horários americanos. A estrada de ferro caminhava adiante da colonização do interior americano, para a qual abria o caminho (Silva, 1904). Também na América foram experimentados os modelos de exploração pública e privada e a regulação teve seus primeiros marcos, influenciando todo o mundo, até os dias de hoje.

\subsubsection{Competição e Discriminação de Preços}

As primeiríssimas ferrovias americanas, iniciadas nos anos 1820 eram empreendimentos públicos, baseados na ideia de open access, mas, devido a escândalos de corrupção, superfaturamentos e déficits fiscais, foram transferidas à iniciativa privada (Silva, 1904). As novas companhias privadas, integradas verticalmente, rapidamente se multiplicaram e se espalharam por todo o território americano, com diferentes modelos de locomotivas e bitolas das estradas de ferro (AR, 2017). Em 1830, a rede ferroviária americana com 86 km, só não era maior que a inglesa com $111 \mathrm{~km}$ (Silva, 1904).

Nessa época, as ferrovias eram vistas como um modo de transporte menos eficiente que os canais de navegação interior, somente eram construídas ferrovias onde a construção de canais era economicamente inviável, todavia, essa percepção mudou rapidamente (Silva, 1904). Em 
1840, a indústria de locomotivas, material rodante e infraestrutura ferroviária já era autônoma da inglesa, tendo os engenheiros americanos criado diversas inovações (Silva, 1904).

Em meados do século XIX a expansão ferroviária era impulsionada pela concessão de terras pelo poder público às empresas ferroviárias, que as revendiam aos colonos financiando os empreendimentos. Entre 1850 e $1880,750.000 \mathrm{~km}^{2}$ foram concedidos, pelo Congresso Nacional, às firmas ferroviárias. Somando-se as concessões estaduais, o total de terras ${ }^{22}$ concedidas era de $861.000 \mathrm{~km}^{2}$, que permitiram a construção de $23.536 \mathrm{~km}$ de trilhos (Silva, 1904).

O sistema de financiamento americano implicava que, na média, naquela época, as firmas ferrovias americanas explorassem uma faixa de domínio de $36,5 \mathrm{~km}$, onde poderiam construir novas povoações e obter receita da valorização dos imóveis. Esse sistema tinha características claramente especulativas, tendo gerado duas crises financeiras, uma em 1854 e outra em 1857. Todavia, por meio do crescimento da população e da geração de riqueza, diversos territórios foram incorporados como Estados à União, a exemplo de: Kansas, em 1861; Virgínia Ocidental, em 1863; Nevada, em 1864; e Nebraska, em 1867. Em 1870, a rede de estradas de ferro já cobria todos EUA, ligando o país do Oceano Atlântico ao Oceano Pacífico (Silva, 1904). Em 1893, era aberta Great Northern Railway a sétima ferrovia transcontinental americana, a primeira sem financiamento público federal, de nenhum tipo, a única a nunca falir em nenhum momento (Grodinsky, 2000).

Nos EUA, as ferrovias eram concedidas pelos Estados, em regime de monopólio na linha, sem, contudo, gozar de exclusividade no trajeto, i.e., se uma firma obtivesse a concessão de uma linha férrea entre dois ou mais pontos, isso não impediria que outra firma pudesse construir outra ferrovia entre os mesmos pontos. Se uma ferrovia cruzasse mais de um Estado precisaria obter a concessão em cada um deles. A concessão garantia a firma o direito de desapropriação forçada, mas impunha que a ferrovia fosse aberta ao uso público, ao mesmo tempo, seguindo princípios da legislação britânica, obrigava que a firma aceitasse, em qualquer tempo, novas obrigações impostas pelo poder público concedente. As legislações estaduais adotavam o regime de liberdade tarifária (Silva, 1904).

Em 1890, sob o regime de liberdade tarifária dos Estados Unidos, as empresas privadas já haviam alcançado a extensão total de $263.283 \mathrm{~km}$ (AR, 2017). A liberdade tarifária, no entanto, sofria forte oposição de alguns grupos de fazendeiros americanos que se organizavam em sociedade sob o nome de National Grange, desde 1867 (Silva, 1904).

\footnotetext{
22 Área equivalente aos Estados de Minas Gerais, São Paulo e Rio de Janeiro.
} 
Nessa época, a concorrência era acirrada entre as firmas ferroviárias. Em consequência, as tarifas de carga e de passageiros eram baixas, supostamente as mais baixas do mundo. A concorrência era mais feroz entre pontos populosos e distantes como Nova York e Chicago. Transportadoras e passageiros poderiam escolher entre uma série de rotas alternativas administradas por diferentes estradas de ferro. Todavia, em rotas curtas, costumava haver apenas uma estrada de ferro que, por isso, gozava de uma situação de monopólio (Friedman \& Friedman, 2015).

Nesse contexto, o lobby dos Grangers apresentou à União pedido para que as tarifas fossem legalmente fixadas pelo governo ou que o governo construísse linhas nacionais cobrando tarifas menores que as praticadas pelas empresas privadas, nas situações de monopólio. Nos governos estaduais, o lobby dos Grangers fez aprovar algumas leis relativas à exploração comercial das ferrovias, a exemplo das leis de Minnesota (1870) e Wisconsin (1874). As companhias recusaram-se a cumprir as leis estaduais. A questão foi levada a Suprema Corte americana em 1876. O Tribunal reconheceu os poderes dos Estados para legislar sobre uma espécie qualquer de indústria de interesse do uso público. As companhias foram derrotadas, mas, não querendo resignar-se, reduziram os serviços, sobre o pretexto de que o Tribunal não poderia obriga-las a operar em prejuízo (Silva, 1904).

A questão foi resolvida com a intervenção do Congresso Nacional que editou o Interstate Commerce Act, de 1887, regulando o assunto. As companhias foram proibidas de aplicar tarifas diferenciadas (discrimination) ${ }^{23}$. A lei criara a Comissão de Comércio Interestadual (ICC - Interstate Commerce Commission) com poderes regulatórios sobre o mercado ferroviário (Silva, 1904).

O apoio dado aos Grangers no Congresso americano e nos Estados contra a política de discrimination das ferrovias não era motivada, exclusivamente, pelo preço alto das tarifas, mas, principalmente, pelos descontos arbitrários e, às vezes, secretos ofertados pelas companhias ferroviárias. Os usuários que não conseguiam tais vantagens sentiam-se prejudicados na livre concorrência em seus mercados, de modo que, ao final, o governo passou a combater a prática (Silva, 1904; Friedman \& Friedman, 2015).

A questão surgia da liberdade de concorrência entre as linhas. Por exemplo, segundo Silva (1904) o transporte de um fardo de algodão entre Winona a New Orleans, distantes $442 \mathrm{~km}$, custava U\$3,25, ao passo que o transporte do mesmo fardo de Memphis a New Orleans,

\footnotetext{
${ }^{23}$ As tarifas precisavam ser fixadas e publicadas com antecedência de ao menos oito dias. Trechos mais curtos não poderiam ser mais caros que mais longos. Usuários associados das ferrovias não poderiam ser beneficiados pelos proprietários das linhas.
} 
distantes $724 \mathrm{~km}$, custava, devido à concorrência, apenas U\$ 1,0. Assim, o fazendeiro de Winona seria prejudicado no comercio de algodão em relação ao fazendeiro de Memphis.

A discrimination também poderia ocorrer quando a carga pertencia à companhia ferroviária ou as suas firmas associadas que recebiam descontos não recebidos por firmas concorrentes (Silva, 1904).

A política de absoluta liberdade tarifária e de concorrência gerou a política de discrimination, que poderia afetar cargas, localidades e classes de passageiros, consideradas ilegais pela legislação americana da época. Como solução, diferente da maioria dos países, onde as falhas de mercado existiam, os americanos optaram pela regulação ao invés de nacionalização das ferrovias, que, devido a imensa extensão da rede, seria financeiramente impossível. Em 1880 a rede ferroviária era de cerca de $150.000 \mathrm{~km}$. Em 1890, três anos após o Interstate Commerce Act a rede ferroviária já era de $263.283 \mathrm{~km}$. Apesar das falhas de mercado, o êxito da política de liberdade tarifária pode ter impedido a estatização das ferrovias, como pretendia parte dos Grangers. As ferrovias eram grandes demais para serem estatizadas.

A liberdade do empreendimento ferroviário americano também incluía a diversidade de bitolas, nos anos 1860, a rede era constituída por nove bitolas principais. Esta diversidade foi resolvida no período 1866-1886. A padronização começou imediatamente após a Guerra Civil americana (1861-1865), por iniciativa da New York Central and Michigan Central Railroads que pagou a Great Western Railway of Southwestern Ontario, pela redução da sua bitola, para a bitola de 1435mm (Puffert, 2002).

O objetivo era ampliar o alcance da ferrovia de New York, conectando-a a outra ferrovia na mesma bitola. As dificuldades logísticas na movimentação de tropas, decorrentes da diversificação de bitolas, convenceram as firmas ferroviárias a reconstruírem as linhas destruídas, na Guerra Civil, em uma única bitola. A bitola eleita pelo mercado foi a de $1435 \mathrm{~mm}$, a mesma eleita duas décadas antes pelo Parlamento britânico, por força do Gauges Act. A unificação foi resultado de três motivações: o forte crescimento da demanda por transporte inter-regional, inclusive para o embarque do grão do meio-oeste até o litoral; o crescimento da cooperação entre linhas de propriedade separada; e a consolidação de sistemas inter-regionais de trunkline sob propriedade comum (Puffert, 2002).

Em 1890, os EUA já haviam padronizado praticamente toda a malha na bitola de $1435 \mathrm{~mm}$ (AR, 2017). Em 1916, no apogeu da rede, a extensão da malha americana era de 408.832 km. 


\subsubsection{Regulação Crescente}

$\mathrm{O}$ astronômico crescimento da malha ferroviária nos Estados Unidos não teve paralelo no mundo. O crescimento americano era claramente especulativo, por ser fundamentado em uma demanda futura e incerta e não na demanda da época (Silva, 1904, Pittman, 2007). As empresas ferroviárias, nos EUA, foram eficientes em tomar vantagem da liberdade empresarial e da verticalização das atividades. A extrema competição intramodal não impediu a unificação rápida de sua malha, em uma única bitola, ao contrário, contribuiu para o crescimento, para a sinergia e para a maior eficiência da malha.

No entanto, o mesmo não se pode dizer sobre a competição intermodal. A competição com o modo rodoviário e com o modo aquaviário, principalmente após a abertura do canal do Panamá, em 1914, juntamente com as constrições regulatórias da ICC, que impedia a liberdade tarifária, levaram ao fechamento de diversos quilômetros de ramais ferroviários, que se tornaram deficitários e à falência de algumas companhias, mas, ao mesmo tempo, ao aumento da produtividade das companhias mais aptas. Em 1963, o mercado americano reduziu a extensão de sua malha para $345.022 \mathrm{~km}$ (AR, 2017).

A falência de ramais ferroviários devido a competição intermodal em meados do século XX foi um fenômeno mundial, que, no entanto, nos EUA, teve desfecho diferente. Novamente, na maioria dos países onde acontecia o fenômeno a solução era a nacionalização de ferrovias ou a adoção de subsídios. Todavia, a rede ferroviária americana era muito grande para ser estatizada. Durante os anos 1970, apesar da maioria das principais ferrovias no Nordeste americano terem falido - incluindo a gigante Penn Central Transportation Company e várias grandes ferrovias do meio-oeste -, não houve um processo de estatização integral das companhias ferroviárias de carga (AAR, 2016).

A solução do governo foi a estatização de somente algumas ferrovias, como, por exemplo, a Penn Central Transportation Company e Erie Lackawanna Railway, unificadas pelo governo federal, em 1976, na estatal Consolidated Rail Corporation (Resor \& Laid, 2013).

A competição intermodal afetava o transporte de passageiro de maneira mais agressiva que o transporte de cargas, que sofria forte ataque do modo aeroviário a partir de meados de 1950. Para mitigar o problema, em 1970, o Congresso americano publicou o Rail Passenger Service Act, por considerar que um serviço moderno, eficiente e interurbano de transporte ferroviário de passageiros é uma parte necessária de um sistema de transporte equilibrado. A medida pretendia evitar o desaparecimento dos serviços de transportes de passageiros pelas empresas ferroviárias privadas, que não mais conseguiam competir com as empresas aéreas americanas. Com o Rail Passenger Service Act ficava então autorizada a criação da National Railroad 
Passenger Corporation (Amtrak) como uma empresa for profit ${ }^{24}$. Com a criação da Amtrak as empresas ferroviárias americanas passaram a ser exclusivamente de cargas. Atualmente, em 70\% dos quilômetros operados pela Amtrak, a estatal utiliza a infraestrutura das empresas de transporte de cargas. $^{25}$

Devido à forte regulação de preços, limitação de serviços e competição intermodal, no fim dos anos 1970 as ferrovias americanas enfrentaram seu pior momento, com sucateamento da infraestrutura, aumento do número de acidentes e diminuição da rentabilidade e da produtividade. (AAR, 2017).

\subsubsection{Desregulamentação}

A solução adotada para mitigar a crise ferroviária americana foi a desregulamentação da atividade, aprovada no Congresso americano por meio do Staggers Rail Act, de 1980. Segundo a Association of American Railroads (2017), o Staggers Rail Act eliminou muitos dos regulamentos mais prejudiciais que impediam o serviço ferroviário de carga eficiente e econômico, pois, notadamente, permitia que:

- estradas de ferro precificassem rotas concorrentes e serviços de forma diferente. Assim, ferrovias poderiam estabelecer preços de acordo com a demanda do mercado e operar sobre suas rotas mais eficientes;

- estradas de ferro e expedidores celebrassem contratos confidenciais. Tais contratos eram virtualmente desconhecidos antes do Staggers Rail Act, devido às restrições regulatórias;

- procedimentos simplificados fossem empregados para a venda de linhas ferroviárias para novas ferrovias de curta distância;

- as autoridades reconhecessem as necessidades de ferrovias para obter receitas adequadas;

- os reguladores autorizassem a exclusão de categorias de tráfego ferroviário da regulamentação se o regulamento não fosse necessário para proteger os carregadores de um abuso do poder do mercado ferroviário. Por exemplo, o frete que poderia ser facilmente transportado pelos concorrentes de transporte rodoviário de ferrovias poderia ser isento da regulamentação.

\footnotetext{
${ }^{24}$ https://history.amtrak.com/archives/rail-passenger-service-act-of-1970

${ }^{25} \mathrm{https}$ ///www.aar.org/todays-railroads/our-network?t=typesofrailroads
} 


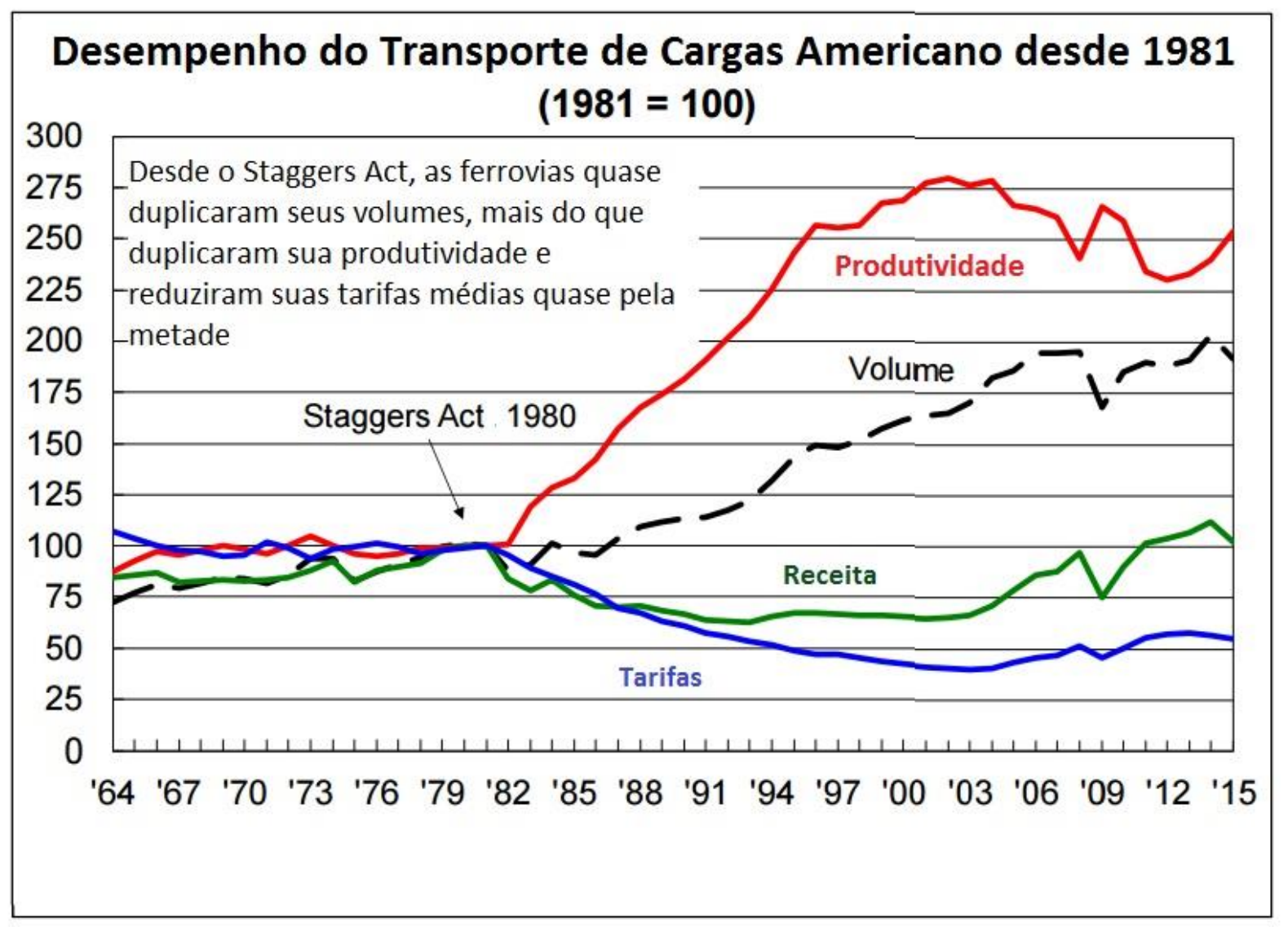

Figura 3.1 Desempenho do setor ferroviário americano entre 1964-2015 Fonte: AAR, 2017.

A figura 3.1 ilustra o aumento substancial da produtividade e volume de carga transportado após a desregulamentação do setor ferroviário americano pelo Staggers Rail Act. Mesmo com a diminuição das tarifas em 50\% entre 1980 e 2015 e, a redução da extensão da rede de $265.255 \mathrm{~km}$ para $222.857 \mathrm{~km}$ no mesmo período, o volume de cargas aumentou $100 \%$ e a produtividade $150 \%$. O Staggers Rail Act representou o fim do combate à política de discrimination fees e a consequente extinção da ICC. De certa maneira, o Congresso americano entendeu que a competição intra e intermodal seriam suficientes para regular os preços do mercado ferroviário. Atualmente, o mercado ferroviário de cargas americano é integralmente privado e tem as características básicas da tabela 3.1:

Tabela 3.1 Mercado Ferroviário Americano

\begin{tabular}{|c|c|c|c|c|}
\hline Ferrovias & Número & Extensão (km) & Empregados & Receita (U\$ bi) \\
\hline Classe I & 7 & 153.312 & 163.464 & 67,6 \\
\hline Regionais & 21 & 16.665 & 5.507 & 1,4 \\
\hline Locais & 546 & 52.880 & 12.293 & 2,6 \\
\hline Total & 574 & 222.857 & 181.264 & 71,6 \\
\hline
\end{tabular}

Fonte: Federal Railroad Administration $(2014)^{26}$

\footnotetext{
${ }^{26}$ http://www.infrastructurereportcard.org/wp-content/uploads/2017/05/C1-140212-001_D1-FRA-Report-onRRs-Report-9-30.pdf
} 
Recentemente, o setor ferroviário privado americano sinaliza voltar a atuar no transporte de passageiros. A nova estratégia, em verdade, é uma atualização do modelo de financiamento adotado no século XIX, a exploração imobiliária dos terrenos lindeiros às estações de passageiros, a exemplo do projeto All Aboard Florida ${ }^{27}$, que pretende ligar Miami, Fort Lauderdale, West Palm Beach e, eventualmente, Orlando por uma empresa privada, financiada integralmente pela rentabilidade do projeto, sem financiamento público federal ou estadual (Brightline, 2017).

\subsection{HISTÓRICO FERROVIÁRIO CHINÊS}

O desenvolvimento ferroviário chinês pode ser dividido em quatro etapas. A preliminar, entre 1876 e 1911. A de integração (network skeleton), entre 1911 e 1949. A de formação de corredores (corridor building), entre 1950 e 1990. A de intensificação profunda (deep intensification), entre 1990 e 2003 (Wang et. al., 2009). E, por fim, a de alta velocidade, a partir de 2003.

\subsubsection{Dúvidas Preliminares}

Em 1876, os britânicos construíram e gerenciaram a primeira ferrovia na China, entre Xangai e Wusong com $15 \mathrm{~km}$. No entanto, um ano depois, o governo da dinastia Qing a demoliu. Nesta fase inicial, a construção ferroviária foi a questão central do debate nacional chinês sobre a modernização da China. Os defensores da nova tecnologia argumentaram que as ferrovias iriam melhorar os padrões de vida da população, mas os adversários contra argumentavam que as ferrovias seriam mais propensas a empobrecer os chineses. Em 1881, o governo chinês decidiu-se em favor da nova tecnologia e iniciou, definitivamente, a construção da rede ferroviária. Em 1911, já haviam sido construídos $9.292 \mathrm{~km}$, a maioria ao norte do rio Yangtze e concentrados em volta de Beijing (Wang et al., 2009).

\subsubsection{Integração Belicosa}

A segunda fase do desenvolvimento ferroviário centrou-se principalmente na extensão das ferrovias existentes e na formação de redes regionais. Durante esse tempo, a China sofreu os efeitos de colonização e invasões por potências estrangeiras e da Guerra Civil (1927-37; 1946-49) e da Segunda Guerra Mundial (1939-45). Nessa época, a rede foi expandida

\footnotetext{
${ }^{27}$ Projeto em construção por iniciativa da Florida East Cost Industries, mais antiga firma do mercado imobiliário da Flórida, fundada pelo pioneiro Henry Flagler no fim do século XIX, atualmente atua na construção civil, infraestrutura e logística. (FECI, 2017)
} 
segundo o interesse do invasor japonês, mas parte significativa da infraestrutura e do material rodante foi destruída ao final da guerra. Ainda assim, o comprimento total das ferrovias em operação era de $21.810 \mathrm{~km}$ em 1949, quase nenhum aumento desde 1937. (Wang et al., 2009).

\subsubsection{Corredores de Segurança}

Após a fundação da República Popular da China, em 1949, o governo central chinês passou a ser o único proprietário, operador e gerente do sistema ferroviário. Desde então, a China adotou um sistema econômico planificado, que incluiu a gestão da infraestrutura ferroviária (Wang et al., 2009). As tarefas ferroviárias, incluindo design, construção, operação e gerenciamento foram completamente tomadas pelo Ministério das Ferrovias (Ministry of Railways - MoR) em Beijing (Lean et al., 2014). Ao governar o crítico setor ferroviário e realizar investimentos em larga escala, desenvolvendo a economia e o bem-estar do povo, o $M o R$ tornou-se um órgão-chave do Estado na China (Mu et al., 2015).

A estrutura organizacional do $M o R$ foi enorme, com 57 agências, departamentos e centros de projetos e 2 milhões de funcionários em diferentes níveis governamentais (Luger, 2010, apud Mu et al., 2015).

No início da década de 1960, quando a China quebrou a relação diplomática com a União Soviética e os EUA estavam envolvidos na Guerra do Vietnã, o governo chinês fez da segurança nacional uma prioridade no desenvolvimento ferroviário. Como resultado, o principal investimento para o transporte foi focado no oeste montanhoso, como Sichuan, Guizhou, sul de Shanxi, e a oeste das províncias de Henan, Hubei e Hunan (Wang et al., 2009).

As ferrovias, então, se tornaram o modo de transporte mais importante e a malha cresceu de $21.810 \mathrm{~km}$ em 1949 para $36.406 \mathrm{~km}$ em 1965 (Wang et al., 2009).

A Revolução Cultural (1966-1976) mudou a estratégia de desenvolvimento econômico, e nesse período apenas algumas novas linhas como Guiyang-Kunming, Chengdu-Kunming, Changsha-Kunming e Pequim-Taiyuan foram construídas (Wang et al., 2009). Naquela época, a construção ferroviária foi realizada por soldados e uma grande parte do orçamento veio de fundos de guerra (Mu et al., 2015).

A partir do final da década de 1970, a China entrou em uma nova era de "Reforma Econômica e Política de Portas Abertas". Em meados da década de 1980, o governo central implementou a estratégia de desenvolvimento da Região Costeira Oriental e mudou o foco do desenvolvimento ferroviário para estimular o desenvolvimento econômico. Nesta fase de 
transição, várias linhas foram construídas e atualizadas. A extensão total das ferrovias chinesas atingiu 53.378 km em 1990 (Wang et al., 2009). Após a reforma econômica, o papel das ferrovias na China mudou-se gradualmente da defesa nacional para atender a demanda de tráfego, conectando primeiro cidades capitais nas regiões orientais e depois desenvolvendo linhas radiais de cidades importantes, incluindo Pequim, Xangai e Cantão (Mu et al., 2015).

\subsubsection{Intensificação Logística}

Entre 1990 e 2003, a China concentrou-se principalmente no fortalecimento dos corredores ferroviários e na expansão da rede, denominada "etapa de construção de corredores". Para reduzir a disparidade regional, o governo central adotou uma estratégia de desenvolvimento equilibrada e deslocou o foco de investimento da Região Leste para as regiões ocidentais, nordestinas e centrais menos desenvolvidas. A expansão da rede continuou em um ritmo acelerado com mais de $1.500 \mathrm{~km}$ de novas linhas construídas a cada ano (Wang et al., 2009). Embora, a expansão da rede tenha sido crescente, a produtividade ferroviária chinesa era considerada muito baixa. Segundo $\mathrm{Mu}$ et al. (2015), o MoR estava fortemente superlotado naquela época. Um representante do Conselho de Estado no $9^{\circ}$ Congresso do Povo (19982003) revelou que o $M o R$ também poderia ser administrado se um terço dos funcionários fosse removido e seria ainda melhor se metade dos funcionários fossem removidos. A má qualidade do serviço levou a uma redução notável na participação de mercado dos serviços ferroviários no transporte de passageiros (Mu et al., 2015; Yin-Nor, 2015).

Em 1980, a participação ferroviária era de 27\%, mas com o desenvolvimento da aviação civil, autoestradas e o aumento da renda per capita, em 2007, essa participação já havia caído para 6\%. Frente ao declínio, o MoR sentiu-se profundamente ameaçado e temia perder sua posição dominante. No início da década de 1990, tentou iniciar mudanças para introduzir ferrovias de alta velocidade na China. O Relatório de Concepção da Linha Ferroviária de Alta Velocidade Pequim-Xangai foi elaborado e discutido durante o $8^{\circ}$ Congresso Popular, em 1993, mas foi posto de lado devido ao enorme encargo financeiro que imporia ao orçamento público. Em vez disso, mais esforços foram feitos para atualizar linhas existentes em termos de velocidade e eletrificação (Mu et al., 2015).

\subsubsection{Alta Velocidade}

A falta de dinheiro não extinguiu a ambição do $M o R$ para desenvolver a rede de trens de alta velocidade (High-Speed Rail - HSR). Sem saber se ou quando a rede de trens de alta velocidade poderia ser introduzida na China, o Ministério ainda fazia muitos esforços para redigir um plano para a rede HSR. Em 2004, foi elaborado o plano de rede ferroviária de 
médio e longo prazo, que incluiu $12.000 \mathrm{~km}$ de linhas dedicadas de passageiros de alta velocidade e três sistemas ferroviários interurbanos de alta velocidade na área da baía de Bohai, o delta do rio Yangtze e o delta do Rio das Pérolas. Todo o plano foi discutido na reunião executiva do Conselho de Estado e novamente não conseguiu obter aprovação (Mu et al., 2015).

No entanto, o Conselho de Estado concordou que o $M o R$ poderia construir a ferrovia PequimTianjin com um comprimento de $117 \mathrm{~km}$ como linha experimental, considerando o potencial aumento do tráfego durante os Jogos Olímpicos de Pequim de 2008, durante o qual alguns jogos de futebol seriam realizados em Tianjin. Este projeto custou 20,42 bilhões de yuan e foi financiado pelo $M o R$ e pelos governos municipais de Pequim e Tianjin. Os trens de alta velocidade foram importados e construídos sob acordos de transferência de tecnologia com fabricantes de trem estrangeiros e, mais tarde, os engenheiros chineses fabricaram os componentes internos do trem e construíram trens nacionalizados que atingiram uma velocidade operacional de $380 \mathrm{~km} / \mathrm{h}$ (Mu et al., 2015).

No final de 2008, o Programa de Estímulo Econômico da China foi promulgado pelo Conselho de Estado na sequência de uma crise financeira mundial que visava à promoção do desenvolvimento econômico através de investimentos públicos em grandes infraestruturas de transporte (Mu et al., 2015). Desde então, os trens de alta velocidade vêm se desenvolvendo rapidamente (Song et. al. 2016). A velocidade e a escala com que as infraestruturas de alta velocidade ferroviária estão se expandindo na China excedem em muito as outras experiências ao redor do mundo (Mu et al., 2015).

A primeira rota $H S R$ da China (Shenyang-Qinhuangdao) com uma velocidade de $200 \mathrm{~km} / \mathrm{h}$ foi inaugurado em 2003, quase 50 anos depois da primeira rota HSR do mundo ter sido aberta no Japão em 1964. Em julho de 2013, porém, a China tinha a maior rede de HSR no mundo com $9.760 \mathrm{~km}$ (Jiao et al., 2014). A China apresentou, formalmente, seu programa HSR, que consiste em linhas dedicadas de passageiros de 18 mil quilômetros no país no Plano de Rede Ferroviária de Médio e Longo Prazo, em 2008, vide figura 3.2 (Mu et al., 2015).

De acordo com o China Statistical Yearbook 2014, a China possuía a maior rede ferroviária de alta velocidade do mundo, em dezembro de 2014, com 16 mil quilômetros de ramais em serviço (Lean et al., 2014). A rede ferroviária de alta velocidade chinesa, que se estende a todas as províncias e regiões da China, consiste principalmente em vias férreas convencionais e linhas recém-construídas com volume de cerca de 2 bilhões de passageiros e volume de frete de 40,99 bilhões de toneladas (Song et al., 2016). 
O crescimento ferroviário chinês, todavia, não se implantou sem críticas. Segundo Mu et al. (2015), o programa HSR na China pôde estimular o crescimento econômico, mas causou uma alta taxa de dívida nacional que constitui uma séria ameaça para a sustentabilidade econômica no longo prazo do país. As regiões orientais são muito mais densamente cobertas com HSR do que as áreas ocidentais, levando a um maior nível de disparidade regional. Cao et al. (2013) mostraram que a desigualdade de acessibilidade em cada uma das regiões e entre os cinco tipos de cidades afetadas pela rede de HSR aumentaram. Em 2013, Liu Zhijun, Ministro chefe do MoR (2003-2013), foi preso e sentenciado a morte acusado de corrupção. No mesmo ano, o MoR foi dissolvido, as funções administrativas foram subordinadas ao Ministério dos Transportes e as funções operacionais foram incorporadas em uma nova entidade pública, a China Railway Corporation (Yin-Nor, 2015).

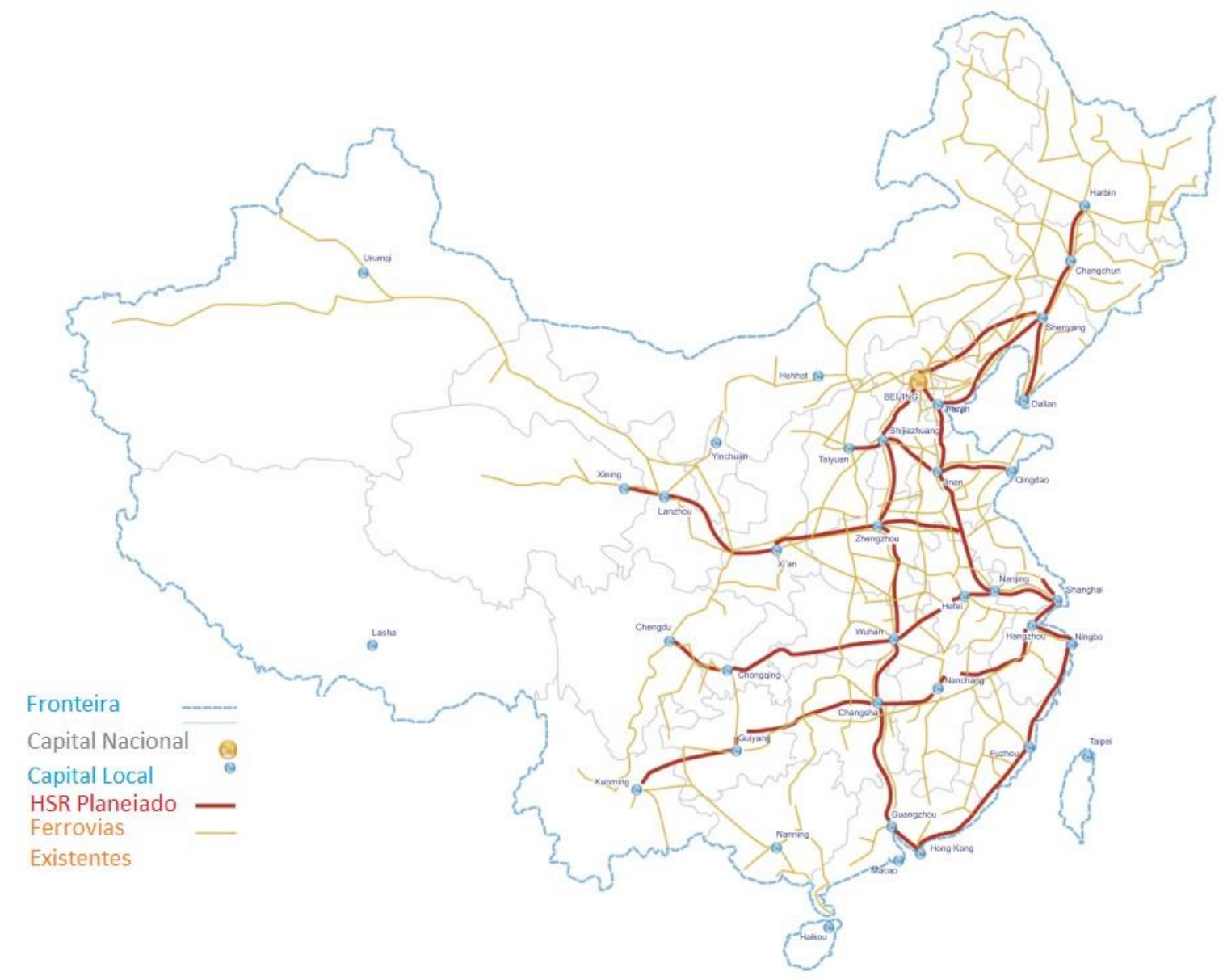

Figura 3.2 Malha ferroviária chinesa - rede de alta velocidade Fonte: Mu et al., 2015

Em 2017, a rede de alta velocidade chinesa, em operação, alcançou a marca de 22 mil km. Na tabela 3.2 é possível observar a extensão da malha de alta velocidade no mundo, comparada a chinesa: 
Tabela 3.2 HSR no mundo

\begin{tabular}{|c|c|c|c|}
\hline País/Região & $\begin{array}{l}\text { Início das } \\
\text { operações }\end{array}$ & $\begin{array}{c}\text { V. Máx. Operacional } \\
(\mathrm{km} / \mathrm{h})\end{array}$ & Extensão (km) \\
\hline Japão & 1964 & 320 & 2.764 \\
\hline EUA & 2000 & 240 & 362 \\
\hline Itália & 1981 & 300 & 923 \\
\hline França & 1981 & 320 & 2.043 \\
\hline Alemanha & 1992 & 300 & 1.014 \\
\hline Espanha & 1992 & 300 & 2.672 \\
\hline Bélgica & 1993 & 300 & 35 \\
\hline Reino Unido & 2003 & 320 & 109 \\
\hline Coreia do Sul & 2004 & 300 & 362 \\
\hline Taiwan (China) & 2007 & 300 & 345 \\
\hline Holanda & 2009 & 300 & 125 \\
\hline Turquia & 2009 & 250 & 688 \\
\hline Europa & - & - & 6.886 \\
\hline Américas (EUA) & - & - & 362 \\
\hline Ásia (sem China e Taiwan) & - & - & 3.814 \\
\hline China & 2003 & $350,300,250$ & 22.000 \\
\hline Total no mundo & - & - & 33.442 \\
\hline
\end{tabular}

Fontes: Cheng, 2010; IGR-Rail (2017); Ryder (2012); Li \& Xu (2016); UIC (2017)

Yin-Nor (2015), relaciona o significativo avanço ferroviário chinês a capacidade do governo central de emular incentivos econômicos aos burocratas ferroviários. Após 1978, a reforma econômica da China mitigou a ideologia da distribuição igual de riqueza oferecendo incentivos materiais legitimados. A febre generalizada para enriquecer enfatizou o ganho material e, ao observar o rápido desenvolvimento do setor privado, os burocratas locais foram atraídos para negociar seu poder político por benefícios econômicos. O MoR ampliou seu poder político e econômico ao verticalizar e diversificar atividades relacionadas direta ou indiretamente as ferrovias. Em 1999, o MoR chegou a administrar 9.345 negócios paralelos. Toda a cadeia de produção ferroviária estava subordinada ao controle do Ministério, universidades, construtoras, fábricas de locomotivas e material rodante, além de milhares de firmas produtoras e destinos das cargas e dos passageiros.

\subsection{HISTÓRICO FERROVIÁRIO BRASILEIRO}

O desenvolvimento ferroviário brasileiro, desde a origem, é marcado por fases de maior liberdade, ainda que com ameaças de intervenção estatal, a fases de concreta atuação estatal com pontuais ações privadas. Nesta seção o histórico ferroviário brasileiro será descrito à luz de suas constantes interações com o governo federal, desde o surgimento no Império, até os dias atuais. 


\subsubsection{Ameaça Fantasma}

O setor ferroviário nasceu, formalmente, no Brasil, a partir de 1835, na vigência do governo do Império, por meio de concessões públicas. Todavia, a primeira concessão de estradas de ferro foi outorgada pelo governo da Província de São Paulo ${ }^{28}$, em 1838, não sendo executada em razão da insegurança jurídica e econômico-financeira do projeto (Silva, 1904).

A segunda concessão ferroviária brasileira foi outorgada pelo governo imperial ${ }^{29}$, em 1840, mas também não fora executada. Ambas as outorgas caducaram devido à falta de garantias financeiras exigidas pelos financiadores ingleses, que não levantavam o capital por empréstimo, como ocorria no caso das ferrovias americanas desde 1833 (Silva, 1904).

Somente com o advento da terceira concessão ferroviária brasileira, é que a primeira estrada de ferro foi construída. A origem da concessão foi o contrato celebrado, em 27 de abril de 1852, pelo governo da Província do Rio de Janeiro, com o empresário brasileiro Irineu Evangelista de Souza $^{30}$. A EF Barão de Mauá foi inaugurada em 30 de abril de 1854. Tinha uma extensão inicial de 14,5 km (Silva, 1904).

O marco regulatório das concessões imperiais brasileiras ${ }^{31}$ previa a cessão de terras governamentais, a isenção de impostos sobre a importação de bens e equipamentos ferroviários, a isenção de impostos sobre a importação de carvão mineral - combustível das locomotivas e a exclusividade de exploração do serviço ferroviário por até noventa anos (Felix e Cavalcante Filho, 2016).

Além disso, aquele marco objetivava o estabelecimento da concorrência pública pelas concessões, a valorização da intermodalidade entre as ligações com hidrovias e portos, o

\footnotetext{
${ }^{28}$ A Lei ${ }^{\circ}$ 115, de 30 de março de 1838, da Província de São Paulo, outorgou, com exclusividade por 40 anos, corredor de transporte, que incluía estrada de ferro, canal de navegação, estrada de rodagem etc, ligando as vilas de Santos, São Paulo, São Carlos, Piracicaba, Itú ou Porto Feliz e Mogi das Cruzes, podendo unir o rio Paraíba ao Tietê. A concessão foi feita a Aguiar Viuva, Filhos \& Companhia e a Platt e Reid (Silva, 1904).

${ }^{29}$ Decreto do Ministro Antônio Carlos Ribeiro de Andrada e Silva de 4 de novembro de 1840, concedia por 80 anos a Thomaz Cochrane, a outorga de uma linha férrea, que se iniciaria na Pavuna, no Rio de Janeiro, passaria por Resende, no rio Paraíba e terminaria na capital de São Paulo. A caducidade dessa concessão foi declarada em 15 de janeiro de 1853, sendo posta a licitação no ano seguinte (Silva, 1904).

${ }^{30}$ Barão e depois Visconde de Mauá foi um empresário pioneiro do setor de transportes. O plano de Mauá era estabelecer um corredor de transporte entre a capital do Império, Rio de Janeiro, e o vale do rio Paraíba, sendo que do Rio de Janeiro ao porto de Mauá na baia da Guanabara o transporte seria feito por navios a vapor, do porto até a Raiz da Serra da Estrela o transporte seria ferroviário, de lá até Petrópolis seguiria em estrada de rodagem e de Petrópolis em diante novamente por via férrea.

${ }^{31}$ Leis: $\mathrm{n}^{\circ} 101$, de 31 de outubro de 1835 , que autorizou o Governo a conceder estradas de ferro da Capital do Império para as de Minas Gerais, Rio Grande do Sul, e Bahia, com o privilégio exclusivo de exploração por 40 anos; $\mathrm{n}^{\circ}$ 641, de 26 de junho de 1852, que autorizou a concessão da construção total ou parcial de estradas de ferro do Município da Corte às Províncias de Minas Gerais, São Paulo e outras, por prazo não superior a noventa anos; $\mathrm{n}^{\circ} 2.450$, de 24 de setembro de 1873 , que concedeu subvenção quilométrica ou garantia de juros às companhias concessionárias de estradas de ferro, na conformidade da Lei $\mathrm{n}^{\circ} 611$, de 26 de Junho de 1832; e $\mathrm{n}^{\circ}$ 7.960, de 29 de dezembro de 1880, que aprovou as cláusulas gerais que deveriam regular as concessões de estrada de ferro no Império, reunindo, assim em um único diploma, as regras de exploração, direitos e obrigações dos concessionários das ferrovias no país.
} 
estabelecimento de garantias contratuais, a previsão de ressarcimento ao governo de juros e subvenções, a fiança do governo central sobre as garantias provinciais, a participação acionária do governo; o princípio da modicidade tarifária, e a reversibilidade dos bens, ao término do contrato (Guerra, 2014).

O marco regulatório do século XIX também costumava prever direito de desapropriação para os terrenos de domínio particular e dos situados nas sesmarias e posses, com as indenizações de direito, e cessão gratuita dos terrenos devolutos e de domínio público nacional. (Silva, 1904).

A partir do marco regulatório do Império Brasileiro, foram construídos 9.076,1 km de linhas férreas, entre 1854 e 1889, dos quais a iniciativa privada, notadamente companhias inglesas, detinha a propriedade e operação de $66 \%$ da rede ferroviária. (Silveira, 2007)

Comparativamente aos valores da expansão americana, a expansão ferroviária brasileira foi bem modesta. Entre algumas das explicações apontadas por Silva (1904), destaca-se a própria natureza do negócio. Nos EUA o empreendimento ferroviário era uma indústria praticamente livre até 1887, com a criação da ICC. No Brasil, diferentemente, a indústria ferroviária desde o início sofria restrições à livre iniciativa, definição de traçados, rotas e principalmente a reversão de ativos.

A ferrovia nos EUA era uma empresa de desenvolvimento territorial, que gozava de amplo apoio político, no Brasil a ferrovia era severamente criticada por muitos setores influentes da sociedade brasileira, que as consideravam "um sacrifício imposto à nação", utilizadas apenas para o escoamento da produção das áreas de plantations (Galvão, 1996). Nesses termos, o custo de oportunidade do investimento internacional no Brasil era muito elevado. Comparado ao Reino Unido e aos Estados Unidos, o investimento aqui estaria mais ameaçado a sofrer perdas por ingerências do governo, intromissões estatais e até mesmo expropriações.

\subsubsection{Ataque dos Juros}

A solução do governo para atrair investimentos foi a garantia de juros (Silva, 1904; Acioli, 2007). Durante a primeira República, o governo brasileiro, a fim de não pagar os juros garantidos a algumas concessões do império, passou a comprar os direitos sobre aproximadamente $2.135 \mathrm{~km}$ de linhas férreas (Silveira, 2007). Não querendo administrar as ferrovias que passavam para as suas mãos, então, o governo Campos Sales (1898-1902) iniciou uma série de arrendamentos. Política que foi continuada nos governos Rodrigues Alves (1902-1906), Afonso Pena (1906-1909) e Nilo Peçanha (1909-1910). Em 1914, as 
empresas privadas operavam 80\% da malha ferroviária e, em 1915, a extensão da rede ferroviária brasileira era de 26.646,6 km (Silveira, 2007).

\subsubsection{Vingança dos Estadistas}

Ainda no começo do século XX, as ferrovias mundo afora passaram a enfrentar a competição de novos entrantes no mercado de provisão de infraestrutura logística, as rodovias (Silveira, 2007). Ademais, devido à forte regulação e microintervenção estatal, muitas empresas privadas tornaram-se deficitárias, algumas foram a falência. A solução do governo para as deficiências das firmas privadas foi um longo processo de encampação. O primeiro governo Vargas (1930-1945), movido por uma estratégia centralizadora, iniciou um processo de saneamento e de reorganização das estradas de ferro e de promoção de investimentos, por meio da encampação de concessões, federais ou estaduais, detidas por empresas estrangeiras ou nacionais que se encontrassem em má situação financeira (Silveira, 2007; Guerra, 2014).

Em 1957, foi criada a Rede Ferroviária Federal S/A (RFFSA) pelo governo Juscelino Kubitschek (1956-1961). O processo de estatização da malha brasileira culminou na progressiva absorção de 42 ferrovias, inclusive a Ferrovia Paulista S/A (FEPASA ${ }^{32}$ ) pela RFFSA (Campos Neto et al., 2010).

Em 1960, o Brasil alcançou o ápice da expansão da malha ferroviária nacional, com 38.287 km de trilhos instalados (Cavalcanti, 2010; Benini, 2012). Obviamente, a expansão da malha nesse período obedecia não a lógica do mercado, mas a lógica do governo, que escolhia os ramais a serem construídos por critérios estratégicos e político-partidários.

Com a crise do petróleo e sucessivas crises econômicas vividas nas décadas de 1970 e 1980, a situação da RFFSA se tornou insustentável. O investimento na malha ferroviária caiu fortemente, houve o sucateamento de sua infraestrutura e as dívidas cresceram de forma rápida (Lang, 2007; Campos Neto et al., 2010).

\subsubsection{Uma Nova Esperança}

A solução gestada na década de 1990, durante o governo Fernando Henrique Cardoso (19952002) para solucionar a crise ferroviária brasileira foi trazer de volta, parcialmente, o modelo empregado para criação do setor durante o Império. Foi proposta a concessão integral das ferrovias administradas pela União (Felix e Cavalcante Filho, 2016).

Para viabilizar o processo de concessões, em 1995, foram editadas as Leis $\mathrm{n}^{\circ}$ 8.987, que dispõe sobre o regime de concessão e permissão da prestação de serviços públicos previstos no art. 175 da Constituição e $n^{\circ}$ 9.074, que sujeitou as vias federais aos ditames da Lei

\footnotetext{
${ }^{32}$ Empresa estatal que unificava a malha estadual paulista
} 
$\mathrm{n}^{\circ}$ 8.987. Para amparar as relações jurídicas decorrentes da exploração da malha ferroviária por meio do mercado, o governo FHC revogou o marco regulatório vigente ${ }^{33}$ em 1996 e editou um novo marco regulatório normativo, a partir do Regulamento dos Transportes Ferroviários, instituído pelo Decreto no 1.832, de 4 de março de 1996 (Felix e Cavalcante Filho, 2016).

Segundo Felix e Cavalcante Filho (2016), esse regulamento - criado às pressas e com vícios de constitucionalidade - disciplinou as relações entre a administração pública e as administrações ferroviárias, as relações destas entre si e com seus usuários, a segurança nos serviços ferroviários, os preços dos serviços e as condições gerais do transporte de cargas e de passageiros.

Entre 1996 e 1999, 25,9 mil km de linhas da RFFSA, divididos em sete malhas geográficas, foram concedidos a empresas privadas. A exploração da rede ferroviária previa contratos de concessão dos serviços e de arrendamento dos ativos. A extensão licitada no governo FHC correspondeu ao que restou dos 33 mil $\mathrm{km}$ administrados pela RFFSA, aí computados 10 mil km subtraídos pelo desmonte de ramais deficitários e os 4,2 mil km acrescidos pela incorporação da antiga FEPASA (Borges \& Oliveira, 2005). A tabela 3.3 apresenta a extensão da malha concedida.

Tabela 3.3 Concessões oriundas da RFFSA e FEPASA (em km)

\begin{tabular}{|c|c|c|c|c|c|c|c|}
\hline \multirow{2}{*}{$\begin{array}{c}\text { Operadoras reguladas pela } \\
\text { ANTT }\end{array}$} & \multirow{2}{*}{$\begin{array}{l}\text { Data do } \\
\text { Leilão }\end{array}$} & \multirow{2}{*}{ Original } & \multirow{2}{*}{$\mathbf{S u b}^{34}$} & \multicolumn{3}{|c|}{ Bitola } & \multirow{2}{*}{$\begin{array}{l}\text { Total } \\
2016\end{array}$} \\
\hline & & & & $1,6 \mathrm{~m}$ & $1 \mathrm{~m}$ & Mista & \\
\hline Ferrovia Novoeste S.A. & 05.03 .96 & 1.621 & 309 & - & 1.953 & - & 1.953 \\
\hline FCA - Ferrovia Centro-Atlântica & 14.06 .96 & 7.080 & 1.246 & - & 7.085 & 130 & 7.215 \\
\hline MRS - MRS Logística & 20.09 .96 & 1.674 & - & 1.708 & - & 91 & 1.799 \\
\hline FTC - Ferrovia Tereza Cristina & 26.11 .96 & 164 & - & - & 163 & - & 163 \\
\hline ALL - América Latina do Brasil & 13.12 .96 & 6.586 & 1.716 & - & 7.223 & - & 7.223 \\
\hline $\begin{array}{l}\text { Companhia Ferroviária do } \\
\text { Nordeste }\end{array}$ & 18.07.97 & 4.328 & 1.623 & - & 4.257 & 20 & 4.277 \\
\hline Ferrovias Bandeirantes S.A & 10.11 .98 & 4.236 & 650 & 1.533 & 305 & 269 & 2.107 \\
\hline Total & & 25.599 & 5.544 & 3.241 & 20.986 & 510 & 24.723 \\
\hline
\end{tabular}

Fonte: ANUT (2011); ANTT (2016); Durço (2011); TCU (2014); Felix e Cavalcante Filho (2016).

Ao transferir as operações das malhas ferroviárias à iniciativa privada, os cofres públicos foram impactados positivamente. Antes do processo de concessão, a RFFSA gerava um déficit anual de R $\$ 300$ milhões. Em 1996, quando as malhas começaram a ser concedidas, o passivo da RFFSA já ultrapassava a casa dos R 2,2 bilhões. Com o processo de concessões, o cenário mudou totalmente. Entre 1996 e 2013, os valores recebidos pelo governo, entre concessão e arrendamento, somaram R \$ 6,684 bilhões, sem contar os tributos federais,

\footnotetext{
${ }^{33}$ Decreto no 90.959 , de 14 de fevereiro de 1985.

34 Trechos e ramais ferroviários subutilizados ou sem tráfego de cargas de acordo com a Deliberação ANTT no 124/julho de 2011. (Anut, 2011) e (Durço, 2011).
} 
estaduais e municipais, totalizando $\mathrm{R} \$ 18,685$ bilhões de receitas aportadas aos cofres públicos (ANTF, 2014).

\subsubsection{O Estado Contra-Ataca}

A partir do governo Lula (2003-2010), a União propôs retomar a diretriz de expansão da malha, por meio de três abordagens: alocação direta de recursos na malha arrendada e concedida, por meio do Departamento Nacional de Infraestrutura de Transportes (DNIT); ampliação de novos trechos, por meio da empresa pública VALEC (Engenharia, Construções e Ferrovias S.A.), que recebeu outorga ${ }^{35}$ para construção e exploração de quatro novas estradas de ferro; e alocação direta de recursos do Orçamento da União na construção de novos ramais, em parcerias com empresas privadas (Felix e Cavalcante Filho, 2016).

A primeira abordagem foi instituída, em 2007, com a criação do Programa de Aceleração do Crescimento (PAC), que, no setor ferroviário, previa investimentos na construção de novos ramais, em bitola larga, e a requalificação de diversos trechos, nas malhas concedidas. Essa abordagem contribuiu, em parte, para o êxito das concessionárias ferroviárias no aumento da produtividade, volume de cargas transportadas e redução de acidentes. Segundo Bittencourt (2009), somente entre 2005 e 2008 foram investidos 0,5 bilhão de reais ${ }^{36}$ pela União nas ferrovias sob o domínio das empresas concessionárias.

Apesar dos benefícios sociais da inversão financeira da União no negócio das empresas concessionárias, Bittencourt (2009) critica a abordagem por: (i) contrariar a lógica essencial das políticas de concessão e privatização (insuficiência de recursos do setor público para investir em infraestrutura); (ii) estabelecer inconsistência na política de transportes, o agente privado pode se valer do comportamento inconstante do poder público para executar um comportamento oportunista na execução do contrato e em futuras licitações; (iii) reduz o valor com arrendamentos e outorgas obtidos pelo poder concedente; (iv) distorce a alocação de riscos adequada aos contratos de coparticipação privada; e (v) não ter precedente internacional.

A segunda abordagem repetiu, em certa medida, a estratégia do governo Juscelino Kubitschek, que criou a empresa pública RFFSA extinta três décadas depois em razão de sua ineficiência operacional e financeira. Diferentemente do governo JK que criou uma empresa pública para consolidar a administração de diversas ferrovias já em operação, a VALEC, nova empresa pública, "recriada" no governo Lula, tinha o propósito de construir quatro novas

\footnotetext{
35 A Lei 11.772, de 17 de setembro de 2008, outorgou à VALEC - Engenharia, Construções e Ferrovias S.A. a construção, uso e gozo das estradas de ferro: EF-151, EF-267, EF-334 e EF-354.

${ }^{36}$ R\$ 595.792.256, valores de 2009.
} 
ferrovias a partir de projetos greenfield em diferentes regiões geográficas do Brasil, como pode ser visto na Tabela 3.4, a seguir:

Tabela 3.4 Ferrovias outorgadas à VALEC - Lei $\mathrm{n}^{\circ}$ 11.772, de 17 de setembro de 2008

\begin{tabular}{|c|c|c|c|c|}
\hline Ferrovia & Trecho & $\begin{array}{l}\text { Extensão } \\
(\mathbf{k m})\end{array}$ & $\begin{array}{c}\text { Trecho } \\
\text { Operacional em } \\
2016 \\
(\mathbf{k m}) \\
\end{array}$ & Situação \\
\hline $\begin{array}{l}\text { EF-151 PA, TO, } \\
\text { GO, MG, SP }\end{array}$ & Belém/PA - Panorama/SP & 2.760 & 764 & $\begin{array}{l}\text { Subconcedido a VLI entre } \\
\text { Açailândia-MA e Palmas- } \\
\text { TO }\end{array}$ \\
\hline EF-267 SP/MS & Panorama/SP - Porto Murtinho/MS & 750 & - & Em estudos. \\
\hline $\mathrm{EF}-334^{37} \mathrm{TO} / \mathrm{BA}$ & Figueirópolis/TO - Ilhéus/BA & 1.527 & - & $\begin{array}{l}\text { Em construção pela VALEC } \\
\text { entre Ilhéus e Barreiras }\end{array}$ \\
\hline \multirow[t]{2}{*}{$\begin{array}{l}\text { EF- } 354 \mathrm{RJ}, \mathrm{MG}, \\
\mathrm{DF}, \mathrm{GO}, \mathrm{MT}, \mathrm{RO}, \\
\mathrm{AC}\end{array}$} & $\begin{array}{l}\text { Litoral norte fluminense - fronteira } \\
\text { Brasil - Peru, Acre. }\end{array}$ & 4.400 & - & $\begin{array}{l}\text { Em estudos pela VALEC e } \\
\text { pela CREC } \\
38\end{array}$ \\
\hline & Total & 9.437 & 764 & \\
\hline
\end{tabular}

Fonte: Felix \& Cavalcante Filho (2016)

A terceira abordagem foi iniciada, ainda no governo Lula, com a contratação da Nova Transordestina, em 2005, mas foi no governo Dilma Rousseff (2011-2016), que a União procurou aplicar a concessão da infraestrutura ferroviária como estratégia principal para expansão da malha, por meio da oferta de cerca de 9 mil $\mathrm{km}^{39}$ de novos ramais. Essa política de concessão ferroviária estava destinada a construção de novos ramais e foi modelada em duas iniciativas dentro do Programa de Investimento e Logística (PIL). O PIL 1 foi lançado em 2012 e continha, no setor ferroviário, a previsão de concessão de 14 ramais divididos em dois grupos. Já o PIL 2 foi lançado em 2015 contemplando a concessão de 5 ramais.

\footnotetext{
${ }^{37}$ A Lei n ${ }^{\circ} 11.772$, de 17 de setembro de 2008, descreve esse ramal com 2.675km de Ilhéus até Lucas do Rio Verde enquanto a Velec, no seu endereço eletrônico, refere-se a esse ramal apenas até Figueirópolis.

${ }^{38}$ CREC (China Railway Group Limited). Contraparte da China em um acordo de cooperação firmado entre Brasil, China e Peru para construção de uma ferrovia entre o Atlântico e o Pacífico.

${ }^{39}$ O Programa de Investimento em Logísitca - PIL 1 (ferrovias) lançado em 2012, previa a concessão de 14 ramais divididos em dois grupos totalizando 9 mil $\mathrm{km}$ de linhas férreas.
} 
Tabela 3.5 Ferrovias PIL 1 Grupo 1

\begin{tabular}{|c|c|c|c|}
\hline Ferrovia & Trecho & $\begin{array}{l}\text { Extensão } \\
(\mathbf{K m})\end{array}$ & Situação \\
\hline EF SP & $\begin{array}{l}\text { Ferroanel São Paulo - Tramo Norte: } \\
\text { Jundiaí - Manuel Feio }\end{array}$ & 53 & $\begin{array}{l}\text { Em estudo para ser incluído como contrapartida } \\
\text { a renovação antecipada do contrato da MRS } \\
\text { Logística (Otta, 2017) }\end{array}$ \\
\hline EF SP & $\begin{array}{l}\text { Ferroanel São Paulo - Tramo Sul: } \\
\text { Ouro Fino - Evangelista de Souza }\end{array}$ & & \\
\hline EF SP & $\begin{array}{l}\text { Acesso ao Porto de Santos: Ribeirão } \\
\text { Pires - Raiz da Serra - Cubatão - } \\
\text { Santos }\end{array}$ & & \\
\hline $\mathrm{EF}-354 \mathrm{GO}, \mathrm{MT}$ & Uruaçu - Lucas do Rio Verde & & $\begin{array}{l}\text { Pertencente ao domínio legalmente outorgado à } \\
\text { VALEC. Em estudos pela VALEC e pela } \\
\text { CREEC. }\end{array}$ \\
\hline $\begin{array}{l}\mathrm{EF}-151 \mathrm{SP} \\
\mathrm{EF}-267 \mathrm{MS}\end{array}$ & $\begin{array}{l}\text { Estrela D'Oeste - Panorama - } \\
\text { Maracaju }\end{array}$ & 160 & $\begin{array}{l}\text { Pertencente ao domínio legalmente outorgado à } \\
\text { VALEC, em fase de estudos. }\end{array}$ \\
\hline EF-151 MA, PA & Açailândia - Vila do Conde & & $\begin{array}{l}\text { Ferrovia pertencente ao domínio outorgado à } \\
\text { VALEC, em fase de estudos. }\end{array}$ \\
\hline & Total & 2.600 & \\
\hline
\end{tabular}

Em termos de transparência, o PIL 1 é pouco documentado. Segundo Sampaio \& Daychoum (2017) o único documento levado a público foi uma apresentação de powerpoint ${ }^{40}$. As tabelas 3.5 e 3.6 ilustram as informações básicas das ferrovias do PIL 1.

Tabela 3.6 Ferrovias PIL 1 Grupo 2

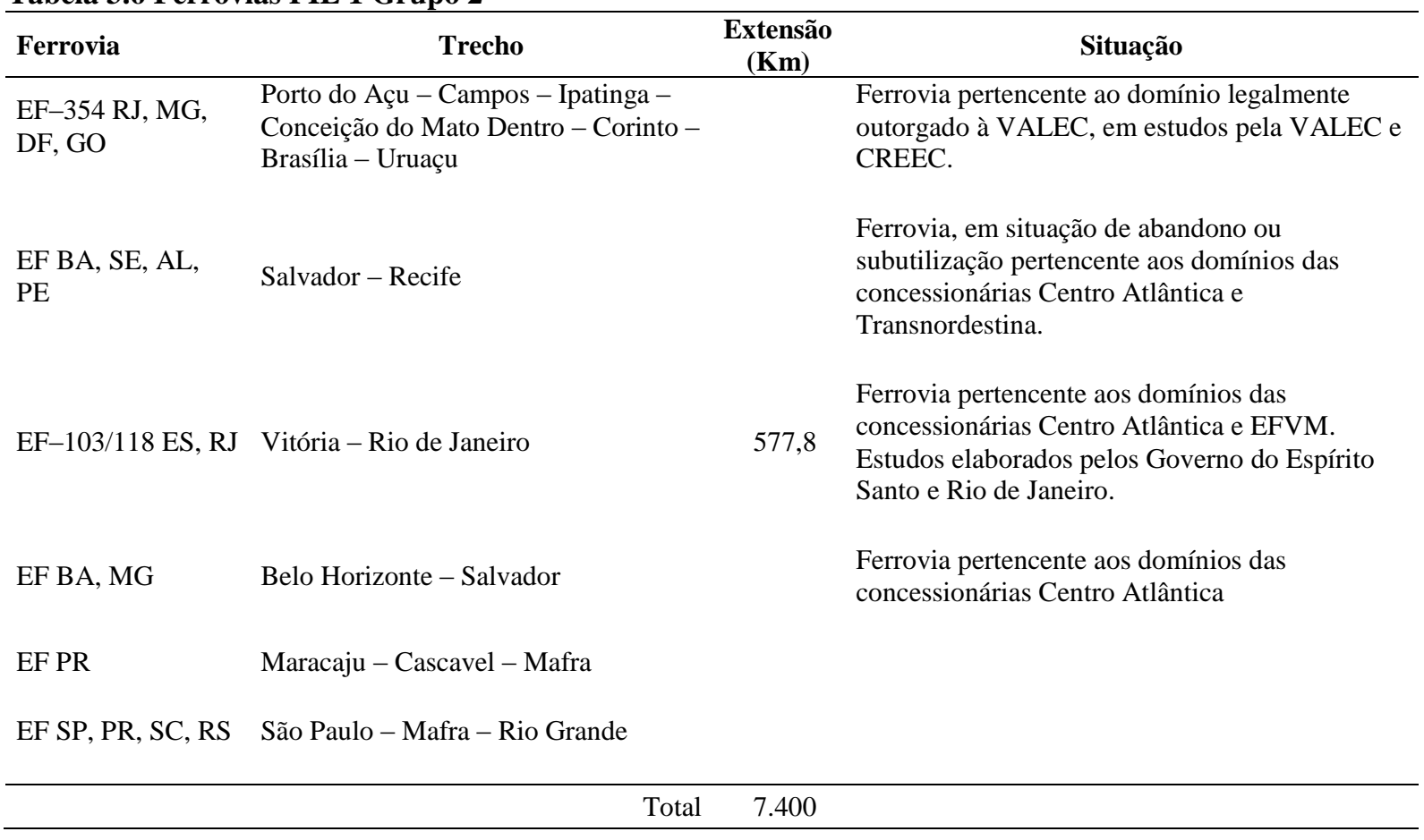

\footnotetext{
${ }^{40}$ PIL I disponível em: http://www.pac.gov.br/pub/up/relatorio/601553fda730f7f943dbeea51cadd538.pdf
} 
O planejamento governamental do PIL 1 (2012) previa que a disponibilização de condições de financiamento ${ }^{41}$ seriam compatíveis com a dimensão dos projetos, a juros fixados pela TJLP mais até $1 \%$, com grau de alavancagem de $65 \%$ até $80 \%$ e carência de até 5 anos, com amortização de até 25 anos.

Entre 2012, ano de lançamento do PIL 1, e 2015, ano de lançamento do PIL 2, o governo reformulou o marco regulatório ferroviário com a incorporação do conceito de acesso aberto (open access). Segundo Felix \& Cavalcante Filho, o governo federal alterou os fundamentos do marco regulatório do setor. Inicialmente foi aberta, pela Lei $n^{\circ} 12.743$, de 19 de dezembro de 2012, a possibilidade de outorga da operação do transporte ferroviário de cargas não associado à exploração da infraestrutura ferroviária a Operador Ferroviário Independente (OFI). E, posteriormente, foi instituída a política de livre acesso ao Subsistema Ferroviário Federal, por força do Decreto ${ }^{\circ}$ 8.129, de 23 de outubro de 2013.

Em 09 de junho de 2015, sem que nenhum quilometro de trilho fosse incorporado à malha pelo PIL 1, foi anunciada pelo Governo Federal a segunda etapa do PIL. Segundo a ANTT (2015), no modo ferroviário, o PIL 2 buscava: ampliar a utilização do transporte ferroviário de carga, criar uma malha ferroviária moderna e integrada; aumentar a capacidade de transporte por ferrovias e diminuir os gargalos logísticos. Naquela oportunidade, foram apresentadas as prioridades do Governo Federal na concessão de novas ferrovias e novos investimentos em concessões existentes, totalizando $\mathrm{R} \$ 86,4$ bilhões de investimentos projetados, ilustrados na tabela 3.7 :

Tabela 3.7 Ferrovias PIL 2

\begin{tabular}{|c|c|c|c|}
\hline Ferrovia & Trecho & $\begin{array}{l}\text { Extensão } \\
(\text { Km) }\end{array}$ & Situação \\
\hline $\begin{array}{l}\text { EF-151 PA, MA, } \\
\text { TO, GO, }\end{array}$ & $\begin{array}{l}\text { Barcarena/PA - Açailândia/MA e } \\
\text { Palmas/TO - Anápolis/GO }\end{array}$ & 1.430 & $\begin{array}{l}\text { Nos domínios legalmente outorgados a Valec em } \\
\text { três situações distintas: greenfield até } \\
\text { Açailândia; subconcedida a VLI/VALE no } \\
\text { trecho central; construída, mas não operacional } \\
\text { entre Palmas e Anápolis }\end{array}$ \\
\hline $\begin{array}{l}\mathrm{EF}-151 \mathrm{GO}, \mathrm{MG} \\
\mathrm{SP} \& \mathrm{EF}-267 \mathrm{SP} \\
\mathrm{MS}\end{array}$ & $\begin{array}{l}\text { Anápolis - Estrela D’Oeste - Três } \\
\text { Lagoas }\end{array}$ & 895 & $\begin{array}{l}\text { Ferrovia nos domínios outorgados a VALEC, em } \\
\text { construção até Estrela D’Oeste/SP e projeto } \\
\text { greenfield até Três Lagoas. }\end{array}$ \\
\hline $\mathrm{EF}-170 \mathrm{MT}, \mathrm{PA}$ & Miritituba - Lucas do Rio Verde & 1.140 & Projeto Greenfield, incluído no projeto Crescer. \\
\hline EF-103 ES, RJ & Vitória - Rio de Janeiro & 572 & $\begin{array}{l}\text { Nos domínios da concessionária Centro-- } \\
\text { Atlântica (VLI/VALE) }\end{array}$ \\
\hline \multirow[t]{2}{*}{$\begin{array}{l}\mathrm{EF}-354 \mathrm{GO}, \mathrm{MT} \\
\mathrm{RO}, \mathrm{AC}\end{array}$} & $\begin{array}{l}\text { Fronteira Brasil - Peru - entrocamento } \\
\text { EF-151 }\end{array}$ & 3.500 & $\begin{array}{l}\text { Nos domínios legalmente outorgados a Valec, } \\
\text { projeto greenfield. Em estudos pela CREEC. }\end{array}$ \\
\hline & Total & 7.537 & \\
\hline
\end{tabular}

\footnotetext{
${ }^{41}$ http://www.planejamento.gov.br/apresentacoes/apresentacoes-2015/rodovias-e-ferrovias-2012.pdf
} 
Segundo Felix e Cavalcante Filho (2016), as inovações no marco regulatório do setor ferroviário trazidas no bojo da política de livre acesso foram recebidas com desconfiança ${ }^{42}$ e aversão pelo mercado e, ao final do governo Dilma, nenhum leilão para outorga de ferrovias foi realizado. O Regulamento do Operador Ferroviário Independente criado no governo Dilma tinha forte inspiração no modelo de exploração do modo ferroviário aplicado na Europa, notadamente no Reino Unido.

\subsubsection{O Retorno do Mercado}

Com o impeachment da Presidente Dilma Rousseff, em 2016, o Governo Michel Temer (2016-2018) sinalizou favoravelmente ao retorno da maior participação privada no mercado ferroviário. Segundo Lodge et al. (2017), o Programa de Parceria de Investimentos (PPI), supostamente, marcou a mudança para um regime "favorável ao mercado", pois alterou o arranjo institucional a fim de dar maior segurança jurídica a novos investimentos privados.

$\mathrm{O} \mathrm{PPI}^{43}$ centralizou o planejamento estratégico anteriormente disperso em matéria de Parcerias Público-Privadas. Esse programa do governo concentrou no recém-criado Conselho do Programa de Parcerias de Investimentos da Presidência da República (CPPI) as funções anteriormente atribuídas ao Órgão Gestor de Parcerias Público-Privadas Federais, ao Conselho Nacional de Integração de Políticas de Transporte (Conit), e ao Conselho Nacional de Desestatização (Sampaio \& Daychoum, 2017). Além disso, vinculou diretamente à Secretaria do programa a Empresa de Planejamento e Logística (EPL). A EPL era anteriormente vinculada ao Ministério dos Transportes. Com essas ações as decisões do governo, seriam, em tese, mais céleres.

O PPI teria como objetivos:

- ampliar as oportunidades de investimento e emprego e estimular o desenvolvimento tecnológico e industrial, em harmonia com as metas de desenvolvimento social e econômico do País;

- garantir a expansão com qualidade da infraestrutura pública, com tarifas adequadas;

- promover ampla e justa competição na celebração das parcerias e na prestação dos serviços;

\footnotetext{
42 Editorial. Revista Ferroviária. Dez 2014/Jan 2015: Regina Perez: "Ninguém espera bons ventos para a economia brasileira neste ano de 2015. Não pode ser diferente entre os agentes do setor ferroviário. O governo já sinalizou, de novo, que vai mesmo rever as concessões. O que pode até não acontecer, por absoluta falta de articulação dentro do próprio governo. Mas a simples reafirmação do que já está virando notícia velha é suficiente para agravar a paralisia dos investimentos e botar os operadores numa posição ainda maior de recuo estratégico. Quem vai investir sem saber quais serão as regras?”

${ }^{43}$ O Programa de Parcerias de Investimentos (PPI) foi criado pela Medida Provisória $n^{\circ} 727$, de 2016, convertida na Lei n⿳0 13.334 , de 2016.
} 
- assegurar a estabilidade e a segurança jurídica, com a garantia da mínima intervenção nos negócios e investimentos; e

- fortalecer o papel regulador do Estado e a autonomia das entidades estatais de regulação.

O segundo marco nesse movimento de retorno do investimento privado foi a Medida Provisória $\mathrm{n}^{\mathrm{o}}$ 752, de 2016, convertida na Lei n ${ }^{\mathrm{o}}$ 13.448, de 2017, que estabeleceu diretrizes gerais para a prorrogação e relicitação dos contratos de parceria definidos nos termos da Lei do PPI. Esse normativo, no setor ferroviário, permitia a prorrogação antecipada dos contratos de concessão firmados nos governos anteriores. Aqueles contratos, geralmente de 30 anos prorrogados por mais 30 anos poderiam agora ser prorrogados antecipadamente se atendidas as seguintes condicionantes:

- o prazo de vigência do contrato de concessão, à época da manifestação da parte interessada, encontrar-se entre 50\% (cinquenta por cento) e 90\% (noventa por cento) do prazo originalmente estipulado;

- a prestação de serviço adequado, entendendo-se como tal o cumprimento, no período antecedente de 5 (cinco) anos, contado da data da proposta de antecipação da prorrogação, das metas de produção e de segurança definidas no contrato, por 3 (três) anos, ou das metas de segurança definidas no contrato, por 4 (quatro) anos; e

- inclusão de investimentos não previstos no instrumento contratual vigente, além da incorporação das melhores práticas regulatórias, novas tecnologias e serviços, conforme acordado com o Ministério ou Agência Reguladora.

Importante notar que a prorrogação antecipada é uma faculdade das partes, não é uma obrigação nem para a empresa concessionária nem para o Estado. No entanto, essa alternativa tende a interessar a ambos os parceiros. Ao Estado interessa porque obtém meios para realizar investimentos que não teria capacidade técnica ou financeira para realizar em curto prazo. Ao Privado interessa porque obtém garantias de que poderá obter retornos financeiros e econômicos por um prazo muito mais alongado e evita a concorrência de novos entrantes. $\mathrm{Ou}$ seja, evita o risco de perder uma eventual relicitação dos ativos ferroviários ao final do termo contratual vigente. Ao tempo que essa dissertação estava sendo escrita cinco concessionárias ferroviárias já haviam sinalizado seu interesse em prorrogar antecipadamente seus contratos, conforme ilustrado na figura 3.3. 


\section{PRAZO AMPLIADO}

- Governo prepara renovação de concessões de ferrovias por mais 30 anos

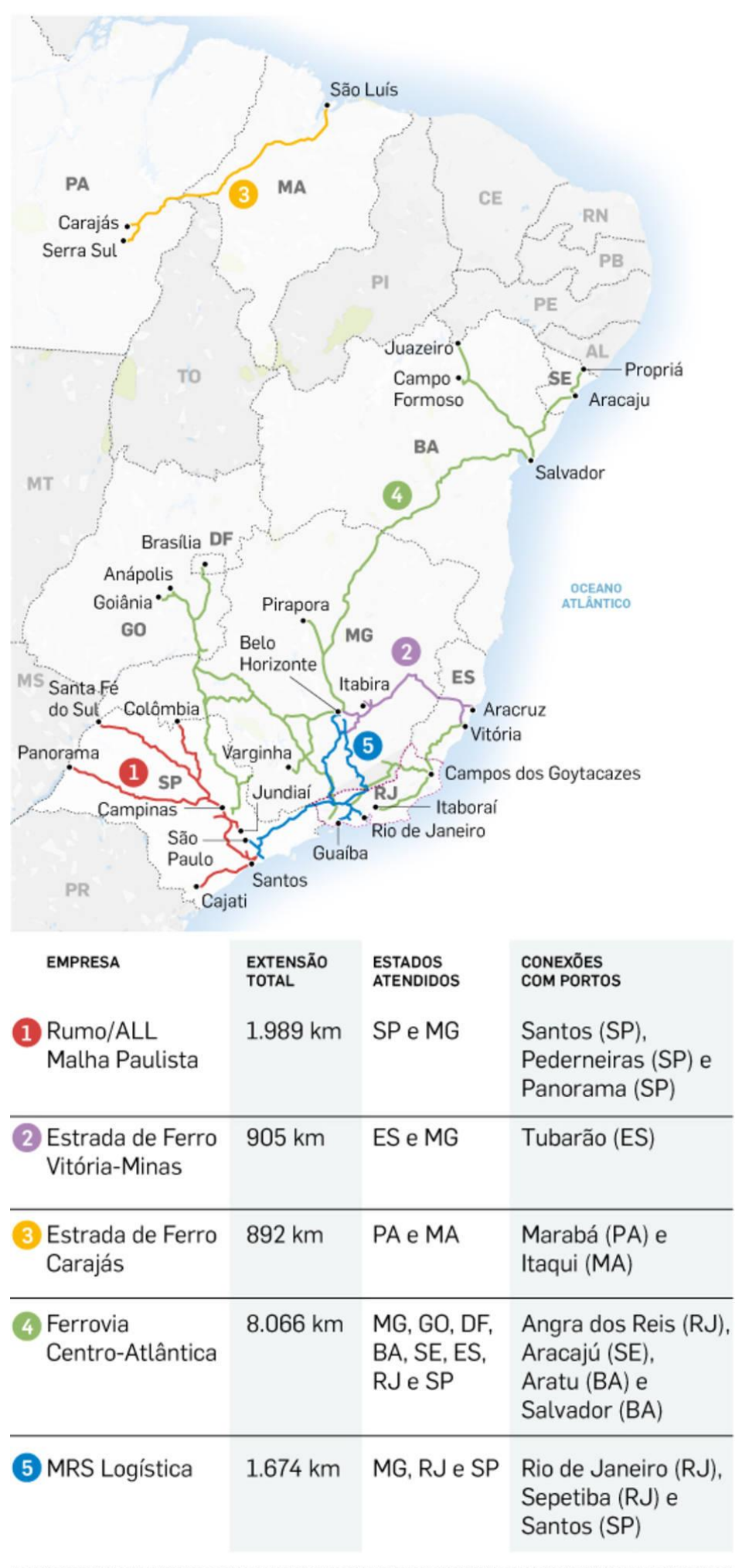

FONTE: ANTF

INFÖGQAFICÖESTAOÄÖ

Figura 3.3 Ferrovias em estudo para renovação antecipada

Fonte: Otta \& Borges, 2017
Observações:

1. O contrato da malha paulista foi firmado originalmente com a Ferrovias Bandeirantes S.A, que venceu o leilão em 10.11.98;

2. Os ativos da Estrada de Ferros Vitória Minas foram concedidos com a privatização da Cia Vale do Rio Doce em 1996;

3. Os ativos da Estrada de Ferros Carajás foram concedidos com a privatização da Cia Vale do Rio Doce em 1996;

4. O contrato da ferrovia Centro-Atlântica foi firmado com o leilão realizado em 14.06.96;

5. O contrato com a MRS Logística foi realizado em decorrência do leilão de 20.09.96.

Com exceção da malha paulista, todos esses contratos começariam a vencer em 2026. 
O ponto mais inovador desse novo marco focado no retorno do mercado não é a possibilidade de prorrogação antecipada dos contratos, que, aliás, já estava prevista nos editais de licitação e contratos do setor ferroviário, mas, a possibilidade de as concessionárias fazerem investimentos fora da área de suas malhas, no interesse da administração:

\begin{abstract}
Art. 25. O órgão ou a entidade competente é autorizado a promover alterações nos contratos de parceria no setor ferroviário a fim de solucionar questões operacionais e logísticas, inclusive por meio de prorrogações ou relicitações da totalidade ou de parte dos empreendimentos contratados.

$\S 1^{\circ} \mathrm{O}$ órgão ou a entidade competente poderá, de comum acordo com os contratados, buscar soluções para todo o sistema e adotar medidas diferenciadas por contrato ou por trecho ferroviário que considerem a reconfiguração de malhas, admitida a previsão de investimentos pelos contratados em malha própria ou naquelas de interesse da administração pública
\end{abstract}

Art. 30. São a União e os entes da administração pública federal indireta, em conjunto ou isoladamente, autorizados a compensar haveres e deveres de natureza não tributária, incluindo multas, com os respectivos contratados, no âmbito dos contratos nos setores rodoviário e ferroviário.

\title{
$[\ldots]$
}

$\S 2^{\circ}$ Os valores apurados com base no caput deste artigo poderão ser utilizados para o investimento, diretamente pelos respectivos concessionários e subconcessionários, em malha própria ou naquelas de interesse da administração pública.

Por meio dessa estratégia o governo federal poderia obter meios para realizar novos investimentos. Possivelmente, parte das ferrovias elencadas nos Programa de Investimento em Logística 1 e 2 poderiam ser retiradas do papel por meio dessa alternativa. Essa opção, embora pareça liberal, como parecia a do Regime Imperial, incorpora a mesma característica estatista centralizadora: a definição dos traçados prioritários pelo interesse estratégico, político e partidário e não pelo interesse puramente econômico. E pode resultar no mesmo fim, a ineficiência dos traçados e o déficit das ferrovias.

Além da parceria com os atuais concessionários o governo federal começou o processo burocrático para licitar mais três ramais ferroviários. As ferrovias eleitas para serem concedidas foram três.

A EF-151, Ferrovia Norte-Sul, qualificada no PPI, pressupõe a concessão de trecho com extensão de 1.537 km, ligando Estrela d’Oeste, em São Paulo, a Porto Nacional, no Estado de Tocantins (PPI, 2017). Essa concessão também estava prevista no PIL 2 de forma mais ampliada, alcançando o porto de Barcarena no Pará.

A EF-170, chamada de Ferrogrão, visa consolidar o novo corredor ferroviário de exportação do Brasil pelo Arco Norte (Vale et al., 2016). A ferrovia conta com uma extensão de 
$1.142 \mathrm{~km}$, conectando a região produtora de grãos do Centro-Oeste ao Estado do Pará, desembocando no Porto de Miritituba. Os investimentos previstos com empreendimento, que é um projeto "greenfield", são estimados em R\$ 12,6 bilhões, incluindo terraplanagem, obras de arte correntes e drenagem, superestrutura ferroviária, obras complementares, obras de arte especiais, compensação socioambiental, desapropriação, sistemas de sinalização ferroviária e energia, equipamentos ferroviários, oficinas e instalações, canteiro de obras, engenharia e material rodante (PPI, 2017). Essa concessão também estava prevista no PIL 2.

A EF-334/BA, Ferrovia de Integração Oeste-Leste (FIOL), destina-se a interligar as regiões Norte e Nordeste do Brasil. Serão aproximadamente 1500 km de vias, entre Figueirópolis, no Estado de Tocantins, até Ilhéus, no litoral baiano. A FIOL atenderá, principalmente, a produção de grãos do Oeste da Bahia e a exploração de minério de ferro, típica da região de Caetité, na área central daquele Estado (PPI, 2017). Essa ferrovia não estava prevista nas concessões do PIL.

A FIOL vinha sendo construída pela VALEC no âmbito do PAC, todavia, vem sofrendo de diversos problemas de governança. A figura 3.4 ilustra as três previsões de concessão no âmbito do PPI, no intitulado Projeto Crescer.

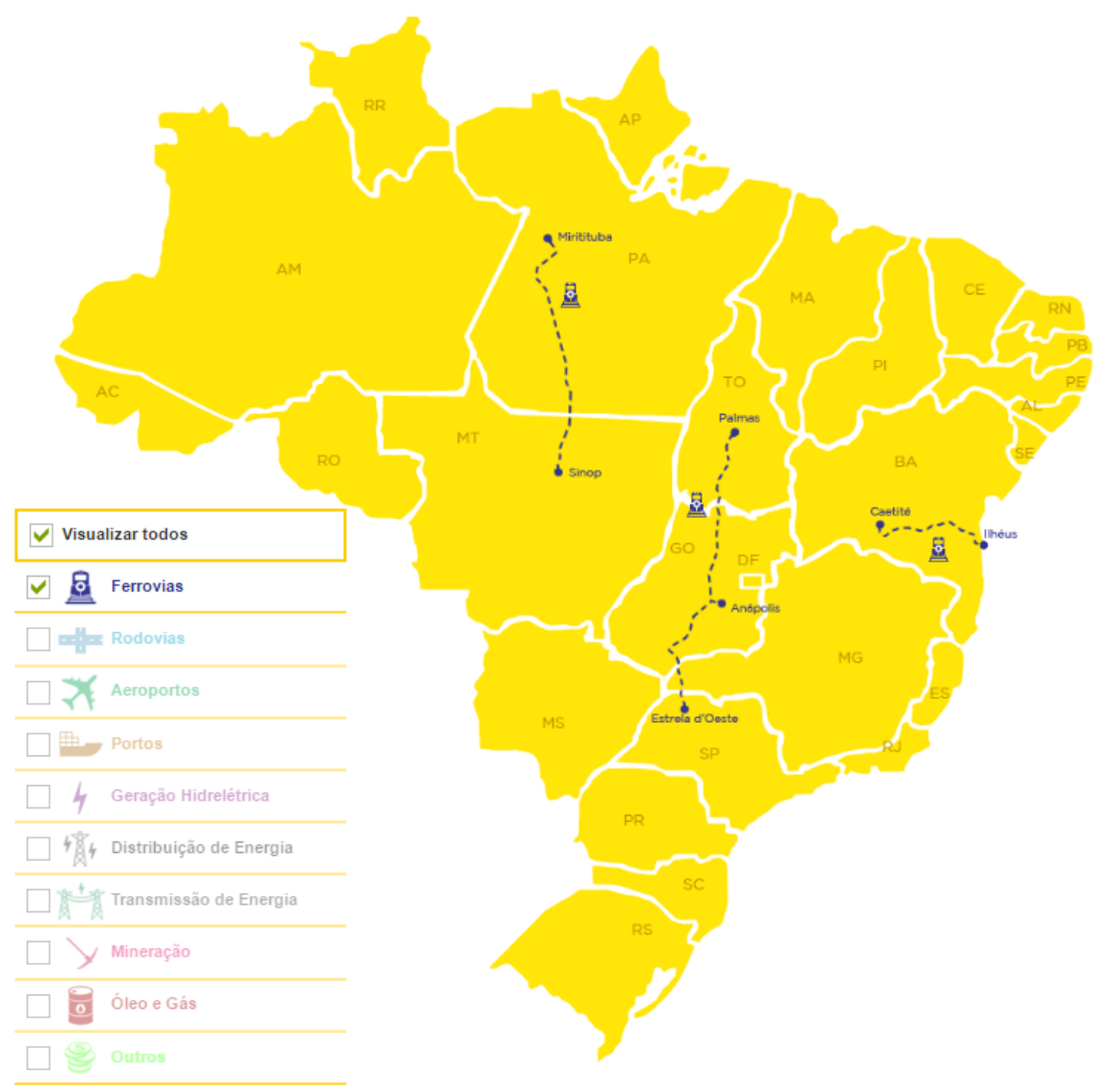

Figura 3.4 Ferrovias previstas para licitação a partir de 2018

Fonte: PPI (2017) 


\section{ENTRAVES BRASILEIROS}

Diversos autores já analisaram os entraves brasileiros do mercado ferroviário, com destaque para Silva (1904), que abordou os entraves do século XIX, à luz de um amplo comparativo internacional. Lang (2007), que elencou a invasão na faixa de domínio, as passagens em nível críticas, os gargalos logísticos, a falta de expansão integrada, a regulamentação, o material rodante e a falta de fontes de recursos. Campos Neto et al. (2010) abordaram a dificuldade de interpenetração de uma concessionária na malha de terceiros, a lacuna de investimentos e a fragilidade do marco regulatório em atrair investimentos. Durço (2011) analisa a questão do risco moral na competição intramodal e as limitações da regulação.

Por razões didáticas, agrupamos os entraves em cinco dimensões ou falhas: a jurídiconormativa, a topológica, a de financiamento, a de mercado e, por fim, mas, não menos importante, a de governo.

\subsection{FALHAS JURÍDICO-NORMATIVAS}

A Constituição Federal distribuiu à União, a competência para explorar, diretamente ou mediante autorização, concessão ou permissão os serviços de transporte ferroviário entre portos brasileiros e fronteiras nacionais, ou que transponham os limites de Estado ou Território (CF, art. 21, inciso XXI, alínea d). Nos termos constitucionais, o transporte ferroviário poderia ser tanto uma atividade econômica, de mercado, outorgada pelo poder público, por meio de autorização, quanto um serviço público outorgado por concessão ou permissão. Ocorre que, a norma infraconstitucional restringiu a exploração das ferrovias à outorga por meio de concessão ${ }^{44}$. A tradição infraconstitucional brasileira, pós-1988, restringiu a exploração do modo de transporte ferroviário aos princípios aplicados aos serviços públicos, com exclusividade. Assim, não existe marco normativo infraconstitucional que proteja a exploração do modo ferroviário como uma atividade de livre iniciativa, nos termos do art. 170 da Constituição Federal.

Essa opção infraconstitucional, de início, é uma das principais falhas jurídico-normativas, mas não é a única, a impedir o desenvolvimento do setor ferroviário, pois, a experiência internacional demonstra que a ferrovia pode sim ser uma atividade integralmente privada, com eficiência e respeito aos direitos dos consumidores. Além da restrição da atividade

\footnotetext{
${ }^{44}$ Vide: Lei $\mathrm{n}^{\mathrm{o}} 10.233$, de 5 de junho de 2001, art. 14, inciso I, alínea a; e Lei no 9.074, de 7 de julho de 1995 , art. $1^{\mathrm{o}}$, inciso IV.
} 
integralmente privada, a insegurança jurídica da exploração do transporte ferroviário por meio de concessão também merece destaque.

\subsubsection{Restrições à Livre Iniciativa Privada}

Assim como no setor ferroviário, no setor portuário não existe nenhuma vedação constitucional para a exploração integralmente privada da infraestrutura portuária. Contudo, até 2013, no plano infraconstitucional, as instalações portuárias privadas sofriam constrições para que fossem restritas ao transporte de cargas próprias. Somente, com a edição da Lei $\mathrm{n}^{\mathrm{o}} 12.815$, de 5 de junho de 2013 , foi positivado marco normativo que garantiu à iniciativa privada o direito de explorar o setor portuário, através de Terminais de Uso Privado (TUP), e mediante outorga por autorização.

A exploração do setor ferroviário, contudo, no plano infraconstitucional continua restrita ao interesse do poder público, que pode exercê-lo diretamente por meio de seus órgãos ou indiretamente mediante concessão a entidades do próprio poder público ou a empresas privadas. Essa restrição impede a plena atividade econômica no setor ferroviário. Novos ramais economicamente viáveis não podem ser explorados por iniciativa do mercado privado, porque, simplesmente, a livre atividade econômica não goza de nenhuma segurança jurídica no plano infraconstitucional.

Mesmo quando o empresariado enxerga a demanda pelo negócio, não o pode exercer, pois, a sua exploração foi restrita ao interesse do poder público, a exemplo da EF-170, que, notoriamente, é do interesse de empresas do agronegócio (Bunge, Cargil, Maggi e Louis Dreyfus), mas, que há anos espera pela iniciativa do poder público de levar a frente um leilão de concessão. Essa falha jurídico-normativa contribui para agravar falhas de mercado, ao excluir um sem número de firmas tanto no campo da prospecção de projetos, quanto da exploração da infraestrutura e operação de trens.

De um ponto de vista estritamente econômico, o Estado Nacional não dispõe mais de recursos suficientes para enfrentar todas as tarefas que pretendeu assumir. Além disso, constatou-se que a utilização dos recursos estatais tende a ser ineficiente: quanto mais intensas e amplas as funções atribuídas ao Estado, tanto maior o desperdício de recursos verificados (Justen Filho, 1998). O sentido de restringir, juridicamente, a entrada de agentes econômicos a uma indústria de base tem pouca ou nenhuma lógica econômica. As barreiras econômicas à entrada - custos afundados, longo prazo de payback, incertezas de demanda, risco de expropriação -, já são suficientemente elevadas para restringir os entrantes, o Estado não precisa impor outras barreiras. 
No setor ferroviário, a outorga por autorização foi restrita a prestação do transporte ferroviário não regular de passageiros e ao transporte ferroviário de cargas por operador ferroviário independente. Em ambos os casos, o transporte não pode ser associado à exploração da infraestrutura, i.e., a firma que explora a infraestrutura deve ser diferente da firma que presta o serviço de transporte autorizado. Essa solução, no entanto, envolve riscos de restrição das receitas, coordenação da atividade e elevação dos custos de transação.

A outorga por permissão, no setor ferroviário, está restrita ao transporte ferroviário regular de passageiros não associado à infraestrutura. Mesmo atualmente, quando intenciona ratificar os contratos de concessão, a ação sinalizada pelo governo é no sentido de restringir as liberdades da firma privada. Ao contrário, no Japão e EUA a iniciativa privada tem liberdades para propor novos negócios livremente, desde que atenda critérios técnicos, de segurança e ambientais.

Veja-se, por exemplo, o trem privado de passageiros entre Miami e Orlando (FACI, 2017). Não se trata de uma outorga planejada pelo Estado e levada à leilão. Ao contrário, trata-se de um planejamento descentralizado privado, meramente autorizado pelo Estado. Legalmente nos EUA, a obrigação de ofertar o transporte ferroviário de passageiros é de uma empresa estatal, Amtrak. Essa obrigação surgiu nos anos 1970 - época de intensa atuação regulatória e foi decorrente da incapacidade do modo ferroviário privado em competir economicamente com o aéreo a partir dos anos 1950. Mas apesar da obrigação ser estatal, i.e. de não haver obrigação legal de firmas privadas exercerem a atividade, também não há impedimento.

Nos EUA, qualquer firma que esteja disposta a construir uma ferrovia pode solicitar uma licença do Surface Transportation Board, que deve ser concedida se o peticionário fornecer a autoridade reguladora provas de que o projeto é economicamente viável e segue as regras regulatórias (Sampaio \& Daychoum, 2017).

Justamente por não haver o impedimento jurídico-normativo, é que nos EUA uma firma de construção civil e logística pode desenhar a engenharia econômico-financeira para implantar um novo ramal ferroviário, associado a construção de lojas, escritórios e residências. Se lá, como aqui, houvesse o impedimento, tal negócio jamais seria elaborado, pois a firma estaria atuando nos mercados de livre iniciativa, como, também o fazem as firmas brasileiras. A falta de iniciativa da Amtrak não foi impedimento para o projeto de financiamento integralmente privado, estimado em U\$ 3.6 bilhões de dólares (Kenton \& Gifford, 2015).

Portanto, o impedimento à ação livre da iniciativa privada é uma falha jurídico-normativa que pode ser superada com a edição de nova legislação. Essa opção não significa troca do público pelo privado, o Estado poderá continuar construindo e ofertando as ferrovias que desejar. 
Significa apenas que a sociedade não precisará depender da iniciativa exclusiva do Estado para a provisão de infraestrutura ferroviária.

\subsubsection{Inseguranças Jurídicas às Concessões}

$\mathrm{O}$ atual marco normativo do setor ferroviário é inseguro para o investidor privado, tanto para os atuais exploradores, quanto para novos entrantes, brasileiros e, principalmente, estrangeiros (Campos Neto et al., 2010; Felix e Cavalcante Filho, 2016). A União, apesar dos avanços recentes, tem usado com parcimônia a faculdade de conceder, permitir e autorizar os serviços de transportes ferroviário pelo setor privado, embora o setor privado, em geral, tenha investido mais e melhor que a União nas áreas de infraestrutura de transportes ferroviário. Mesmo com os investimentos privados, o Brasil, entre os países em desenvolvimento, tem sido o que menos investe em empreendimentos de infraestrutura de transportes. Parte da falta de investimento privado em parcerias (concessões, permissões ou autorizações) é resultado do elevado grau de insegurança jurídica no setor ferroviário.

Segundo, Felix e Cavalcante Filho (2016) o marco regulatório normativo do setor ferroviário tem problemas jurídico-formais que o tornam precário e questionável, notadamente por vícios de constitucionalidade e excessiva normatização infralegal. A legalidade é, portanto, um primeiro objetivo a ser alcançado. A adequada institucionalização do marco normativo do setor ferroviário, em nível de lei - espécie de natureza mais estável e perene, na comparação com os decretos presidenciais e com as resoluções da ANTT -, já será um grande passo para a redução das incertezas sobre as regras do jogo (Felix e Cavalcante Filho, 2016).

Em outras palavras, o atual marco regulatório do setor de ferrovias no Brasil constitui, em si mesmo, uma dupla causa de insegurança jurídica para o setor, tanto por sua inconstitucionalidade formal, como pela instabilidade decorrente de um instrumento normativo que pode ser alterado por decisão individual de um agente político, o Presidente da República, sem a necessidade de qualquer debate interinstitucional (Felix e Cavalcante Filho, 2016).

Atualmente, a exploração da infraestrutura ferroviária depende de prévia concessão, mas as vias férreas disponíveis sofrem de pesados entraves decorrentes da falta de manutenção em suas infraestruturas, muitas das quais seculares. O marco normativo ferroviário deveria ser reformulado e modernizado, para garantir que as empresas concessionárias e autorizadas permitissem a operação em suas malhas de forma recíproca. Nesse modelo, caberia à União apenas impedir a diversificação bitolas além das duas já em uso no sistema e propor pontos de 
conexão intermodal com a infraestrutura antiga, a fim de que a sinergia da rede fosse ampliada, como um todo (Felix e Cavalcante Filho, 2016).

A abertura do mercado de operação de transporte de cargas por operador ferroviário independente, mediante outorga por autorização, conforme a Lei $\mathrm{n}^{\circ} 12.743$, de 19 de dezembro de 2012 ainda está incompleta. Até 28 de novembro de 2016, quatro anos após a abertura do mercado, apenas duas ${ }^{45}$ empresas haviam sido autorizadas pela ANTT a operar como operador ferroviário independente, como se pode observar na tabela 4.1. Contudo, até dezembro de 2016, nenhuma empresa nova transportou cargas no sistema ferroviário brasileiro apesar da abertura jurídica do mercado (Felix e Cavalcante Filho, 2016).

Tabela 4.1 Situação dos requerimentos de autorização para OFI em 2016

\begin{tabular}{ccc} 
Empresa & $\begin{array}{c}\text { Solicitação } \\
\text { (ano) }\end{array}$ & Situação \\
\hline Agrovia S.A. & 2015 & Em análise \\
Brado Logística S.A. ${ }^{46}$ & 2015 & Arquivado \\
Tora Logística Armazéns e Terminais Multimodais S.A. & 2015 & Autorizada \\
GME4 do Brasil Participações e Empreendimentos S.A. & 2015 & Em análise \\
Geoterra Empreendimentos e Transportes S.A. & 2016 & Autorizada \\
\hline
\end{tabular}

Fonte: ANTT, 2016; Felix e Cavalcante Filho (2016).

Fenômeno semelhante ocorreu na Finlândia, que, apesar de ter aplicado a desregulamentação orientada pela legislação da União Europeia, não obteve, automaticamente, a concorrência no mercado (Makitalo, 2011). Não, pelo menos, nos primeiros três anos de aplicação da norma.

Makitalo (2011) sugere que o mercado finlandês de transporte ferroviário é parcial, apesar de ter aplicado a legislação europeia, e que a distorção da estrutura do mercado favorece a empresa ferroviária estabelecida, devido à influência passiva da política governamental local no acesso aos serviços dos operadores pré-estabelecidos, na organização do controle de tráfego e no treinamento da mão de obra.

Em 2015, foram submetidas à análise técnica da ANTT quatro requerimentos e em 2016, houve apenas um pedido de autorização para OFI, conforme a tabela 4.2. Como paradigma de comparação, em 2007, a Alemanha, a Grã-Bretanha e Suécia, que também abriram seus mercados a operações independentes, tinham 315, 26 e 17 operadores de carga independentes da exploração da infraestrutura, conforme tabela 4.2.

\footnotetext{
45 As autorizadas são: Tora Logística Armazéns e Terminais Multimodais S.A., que foi autorizada pela Resolução $n^{\circ}$ 5.027, de 18 de fevereiro de 2016, publicada no DOU em 22 de fevereiro de 2016 e Geoterra Empreendimentos e Transportes S.A. que foi autorizada pela Resolução no 5.222 , de 23 de novembro de 2016, publicada no DOU em 28 de novembro de 2016.

${ }^{46}$ A Brado Logística S.A. foi criada em 2010 pelo grupo ALL, para atuar no serviço de logística intermodal de contêineres. Atualmente, faz parte da RUMO que controla a ALL.
} 
Tabela 4.2 Mercado ferroviário de cargas alemão, britânico e sueco em 2007

\begin{tabular}{lrrr}
\hline & Alemanha & Grã-Bretanha & Suécia \\
\hline Ano de abertura do mercado & 1994 & 1994 & 1998 \\
Empresas exploradoras de infraestrutura & 59 & 11 & 9 \\
Empresas operadoras de trens & 315 & 26 & 17 \\
\hline
\end{tabular}

Fonte: Nash et al. (2011), Felix e Cavalcante Filho (2016).

A evidência que se extrai é que a norma tem que ser compatível com o mercado, não existe apenas um modelo. Cada país tem características próprias que requerem soluções específicas, às vezes mais de um modelo legal ou regulatório a depender das condições de competição do mercado. A escolha depende de características intrínsecas de tráfego, escala, densidade e demandas de mercado de cada realidade e, não, necessariamente, a melhor opção envolve a escolha de um único modelo (Takasaki, 2014).

A intervenção regulatória deve ser leve e focada nos mercados em que a dominância do modo ferroviário é a mais importante que os demais modos. Sempre que a ferrovia enfrenta uma concorrência intermodal adequada é desnecessária uma intervenção regulatória pesada ou específica no setor. A ferrovia deve ser deixada para competir no mercado por seus méritos. A intervenção estatal, onde pode justificar-se, deve concentrar-se apenas nos mercados nos quais as ferrovias poderiam ter uma posição dominante (Nash \& Torner, 1998).

Se o Operador Ferroviário Independente criado pela Lei $\mathrm{n}^{\circ} 12.743$, de 2012, for mantido no sistema jurídico, maior será a necessidade de um novo marco legal, pois o acesso aberto é problemático de ser regulado, especialmente se o concessionário das estradas de ferro também puder prestar serviços em competição com os operadores independentes. Nesse caso, conflitos de interesse irão aumentar caso uma regulamentação econômica sólida não seja instituída para garantir condições equitativas a todos os operadores (Felix e Cavalcante Filho, 2016).

\subsection{FALHAS DA TOPOLOGIA}

Por questões históricas ligadas a formação da rede e sua privatização, a atual rede ferroviária brasileira apresenta uma topologia que não incentiva a competição e a produtividade. A eficiência das ferrovias depende diretamente da topologia da rede (Puffert, 2002). Da mesma forma, a capacidade de uma rede ferroviária gerar competição inter e intramodal também depende de sua topologia. Aliás, a capacidade estatal de expandir a topologia da rede é mais importante para a eficiência do que a própria administração da rede (Bogart, 2010). Nesta seção serão analisados alguns dos problemas principais da topologia, entre eles a diversidade 
de bitolas, a monopolização em bacias geográficas, as falhas de traçados, o abandono dos ramais.

\subsubsection{Diversificação de Bitolas}

Uma das primeiras falhas da topologia é a diversidade de bitolas, que aliás, é uma falha subestimada na cartografia oficial. Veja-se por exemplo o mapa oficial do anuário estatístico do Ministério de Transportes, de 2017, vide figura 4.1.

A reambulação ${ }^{47}$ do mapa, ilustrada na legenda, apresenta apenas duas informações quanto a identificação das ferrovias: a nomenclatura da concessionária ferroviária e o estágio operacional, se em operação ou se desativada. A bitola da ferrovia, informação essencial para definição de rotas e compreensão da utilidade dos ramais, é omitida. Assim, o leitor não inteiramente informado, poderia supor, que um mesmo trem seria capaz de realizar a rota, de cerca de 730km, entre Uruaçu-GO e Uberaba-MG. Todavia, devido as diferenças de bitola, isso não seria possível, já que a ferrovia que passa em Uruaçu está na rede em bitola larga, enquanto a ferrovia que passa Uberaba está na rede em bitola estreita.

\footnotetext{
${ }^{47}$ Reambulação é a técnica de identificar e nomear feições conhecidas do usuário em carta topográficas, mapas
} ou imagens de satélite. 


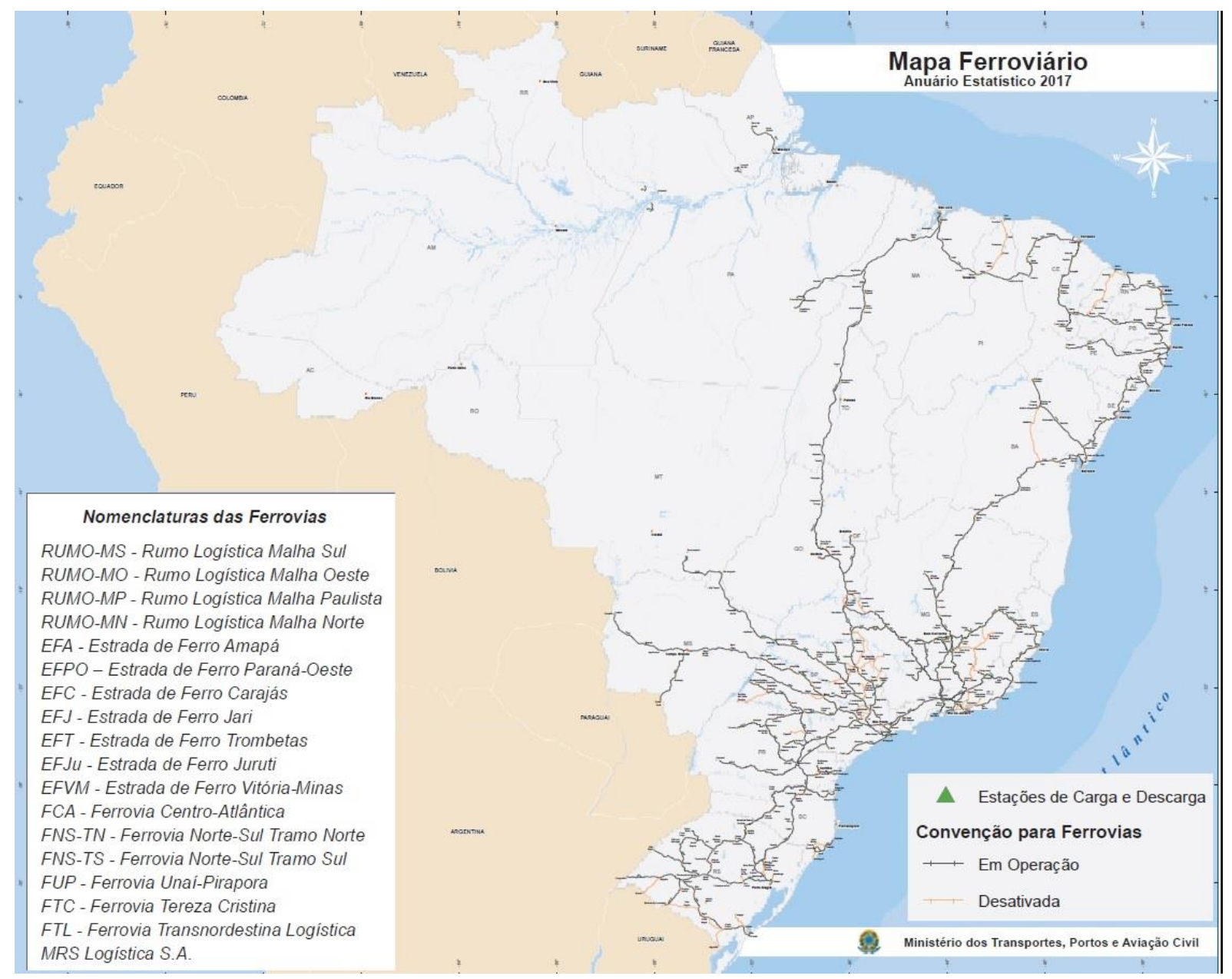

Figura 4.1 Mapa ferroviário do Brasil, 2017

O Brasil, no transporte de ferroviário de cargas, em verdade, possuí duas redes ferroviárias, como ilustrado na adaptação de Théry \& Mello, da figura 4.2. Diferentemente de Inglaterra, Estados Unidos, Canadá, México, China e diversos países europeus, o Brasil não unificou a bitola de sua malha ferroviária. Segundo Cury (2011), a unificação de bitola só foi tentada no Brasil, como um plano governamental, ainda que de maneira incompleta, a partir dos governos militares, com maior destaque para o do Presidente Médici (1969-1974). Nessa época, os militares passaram a estimular a construção de novas ferrovias na bitola larga, quando a bitola dominante até então, e também atualmente era a bitola estreita. A opção atribuída aos militares foi mantida nos governos democráticos, de maneira que novas ferrovias foram e estão sendo construídas na bitola larga, a exemplo de: Ferrovia do Aço (1976), Estrada de Ferro Carajás (1985); Ferronorte (1998); Ferrovia Norte-Sul (1996), etc.

Os motivos técnicos e econômicos para a escolha da bitola larga são desconhecidos e bastante discutíveis (Curry, 2011). Araújo (1986) faz críticas a escolha da bitola larga como modelo de unificação em razão de seus custos mais elevados. Para ele o que torna eficientes os sistemas 
ferroviários de Estados Unidos, Canadá, Inglaterra, Europa Ocidental são: a cobertura espacial dos mercados nacionais e internacionais a que servem e a unificação, e não a largura da bitola. Cabe lembrar que alguns desses países fizeram a unificação integral de suas malhas na bitola Standard há mais de 100 anos. A opção pela bitola larga, indubitavelmente, é a mais onerosa entre as possíveis, agravado pelo fato de que nenhum dos países vizinhos do Brasil utiliza a bitola larga de $1600 \mathrm{~mm}$.

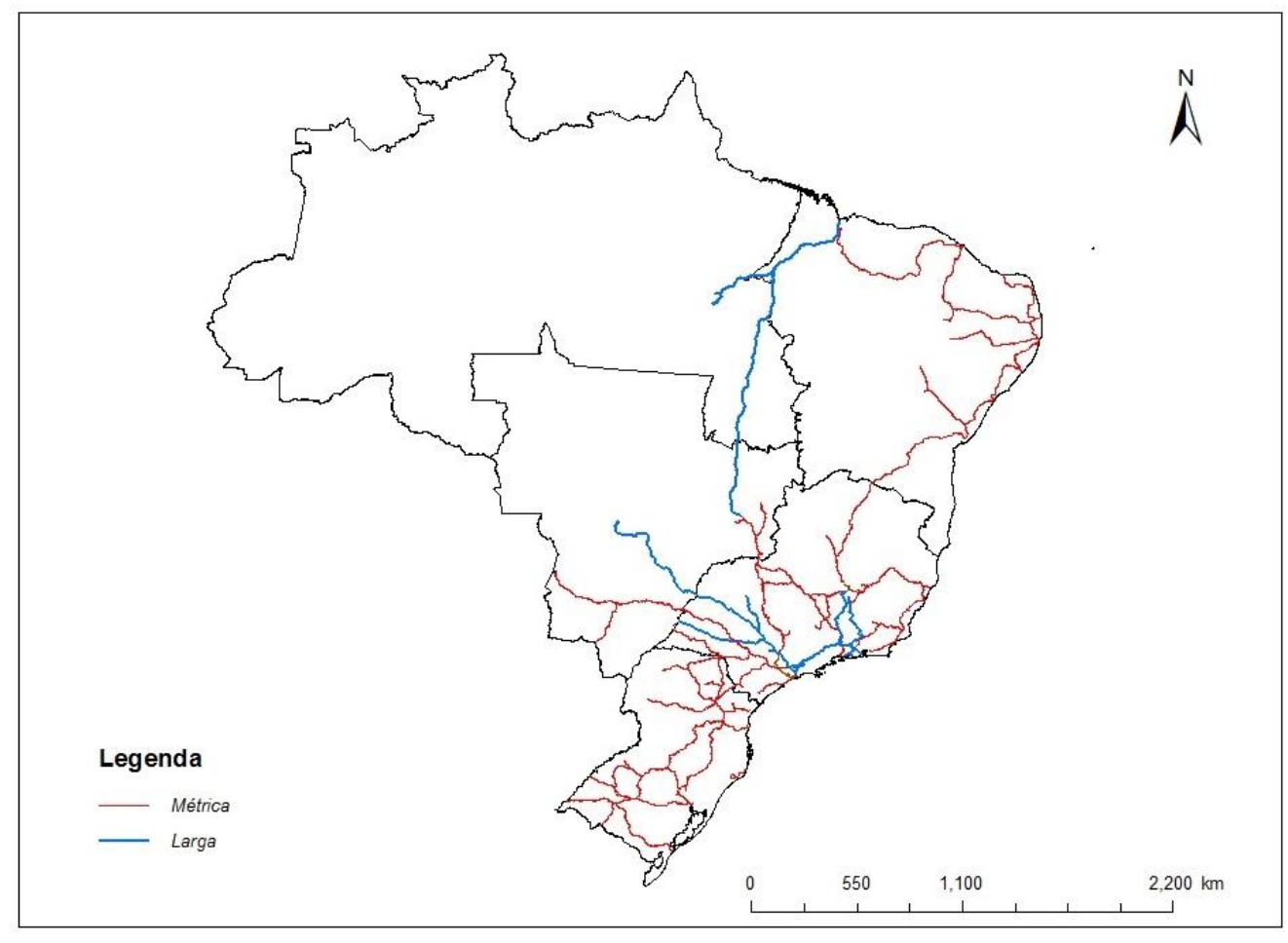

Figura 4.2 Rede ferroviária brasileira por bitolas

Fonte: ANTT (2017) inspirado em Théry \& Mello (2005), com adaptações.

O Peru, que intenciona conectar-se ao Brasil por meio de uma ferrovia transoceânica adota a standard como bitola oficial. Se cada país utilizar sua bitola oficial em uma eventual ferrovia transoceânica, precisaria haver na fronteira entre os dois países, possivelmente no Acre, no meio da floresta amazônica um mega terminal de transbordo de cargas, fato que poderia inviabilizar a construção da ferrovia.

Se no governo dos militares não tivesse havido uma intervenção estatal direcionando as ferrovias para a bitola larga, i.e. se as novas ferrovias continuassem sendo construídas na bitola dominante da época, a bitola estreita de 1000mm, em 2017, possivelmente somente haveria pouquíssimas ferrovias em bitolas minoritárias, eventualmente: a estrada de ferro do 
Amapá $^{48}$, inaugurada na bitola standard, em 1957; e as ferrovias associadas a extinta Companhia Paulista, inaugurada, em 1872.

\subsubsection{Monopolizações Regionais}

Como visto na história da exploração da infraestrutura ferroviária da Inglaterra, a aglutinação de ferrovias era uma forma de se evitar os efeitos da concorrência a pretexto de racionalização da malha. Quando houve a privatização da RFFSA, nos anos 1995, a malha foi então dividida em sete grandes ferrovias. Com o passar dos anos, por meio de aquisições e fusões a as ferrovias brasileiras, que chegaram a ser 42 firmas distintas foram reduzidas a apenas seis firmas, como pode ser observado na ilustração da figura 4.3.

Segundo o mapa da ANTF (2017), com exceção da ferrovia Tereza Cristina no litoral de Santa Catarina, todas as estradas ferrovias existentes no Rio Grande do Sul, Paraná, Santa Catarina, Mato Grosso do Sul e Mato Grosso estão sobre o monopólio de uma única firma, a Rumo-ALL. No Estado de São Paulo, a Rumo-ALL controla todas as ferrovias, exceto os ramais da MRS Logística.

A única região do país com alguma possibilidade de concorrência teórica entre concessionárias é o entorno de Belo Horizonte, servido por três ferrovias: MRS Logística, desaguando nos portos de Santos e sul do Rio de Janeiro; VLI - Centro Atlântica, desaguando nos portos do norte do Rio de Janeiro e Vitória; e VALE - EF Vitória a Minas, desaguando no porto de Vitória. Todo o resto do país está circunscrito a algum arranjo de monopólio em que apenas uma firma ferroviária dá acesso aos portos oceânicos.

\footnotetext{
${ }^{48}$ Ferrovia atualmente desativada
} 


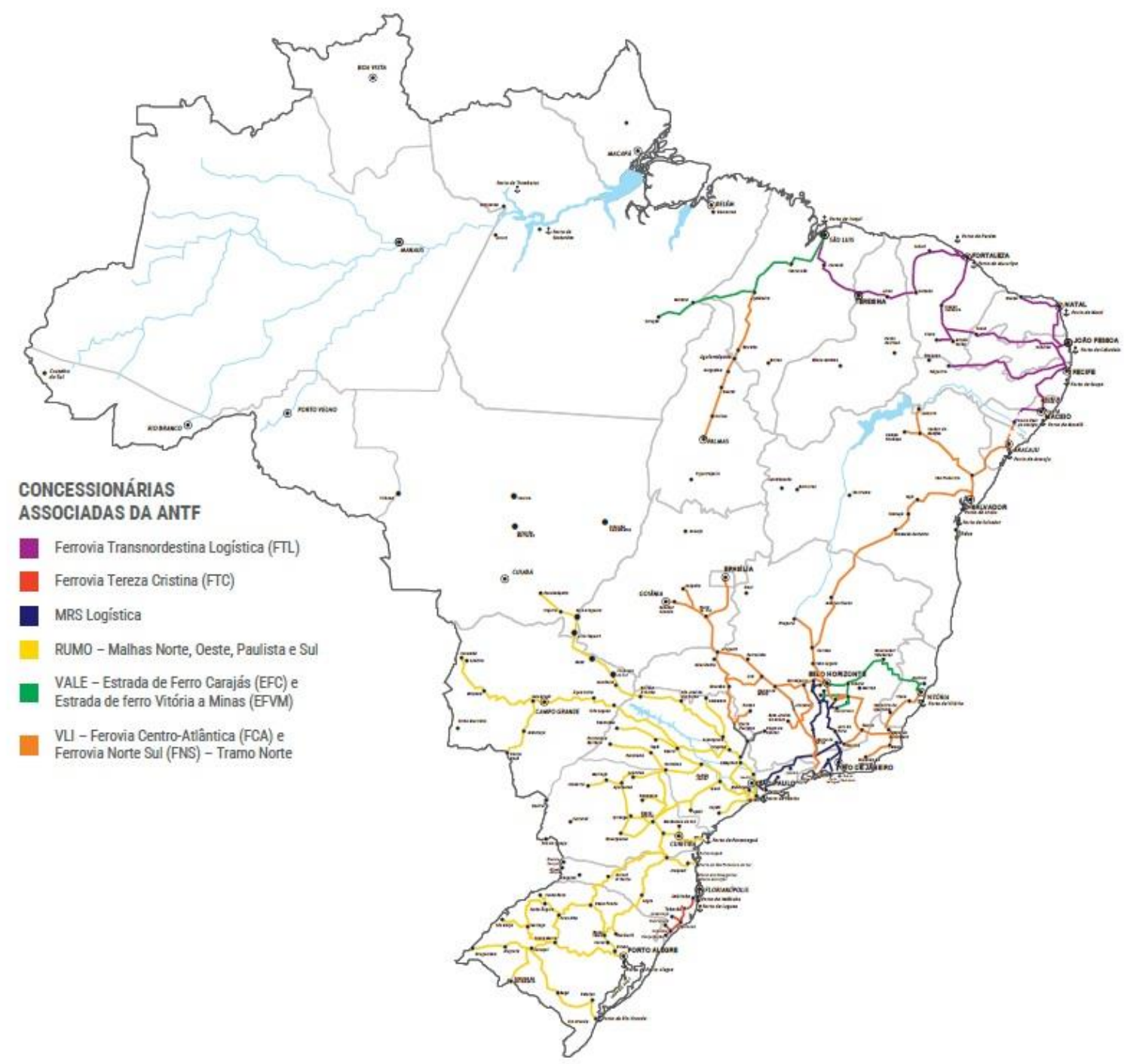

Figura 4.3 Rede ferroviária brasileira por concessionárias Fonte: ANTF, 2017.

\subsubsection{Falhas de Traçados}

As alegações de que os traçados das ferrovias brasileiras atenderam a motivações políticopartidárias dos governos de ocasião, ao invés de interesses puramente econômicos, como demanda, utilidade e viabilidade econômica, são extensas. Verdadeira ou falsa a alegação, é fato que os traçados ferroviários, em geral, atendem um padrão de topologia em forma de árvore, conectando geralmente os portos nas capitais ao interior, com pouca ou nenhuma conexão no interior entre os Estados. Veja-se, por exemplo, as ferrovias do Nordeste na figura 4.4. Na Bahia, a ferrovia que liga Salvador a Juazeiro, não continua e adentra no Estado de Pernambuco. Em Pernambuco, da mesma forma a ferrovia que liga Salgueiro à capital Recife não tem nenhum ramal que a conecte economicamente com o porto de Maceió, em Alagoas. São raros os ramais internos que poderiam aumentar a concorrência entre os portos. 
Uma ligação ferroviária entre Missão Velha-CE, Salgueiro-PE e Juazeiro-BA, se existisse, talvez tivesse inviabilizado o projeto da Nova Transnordestina, de 2005.
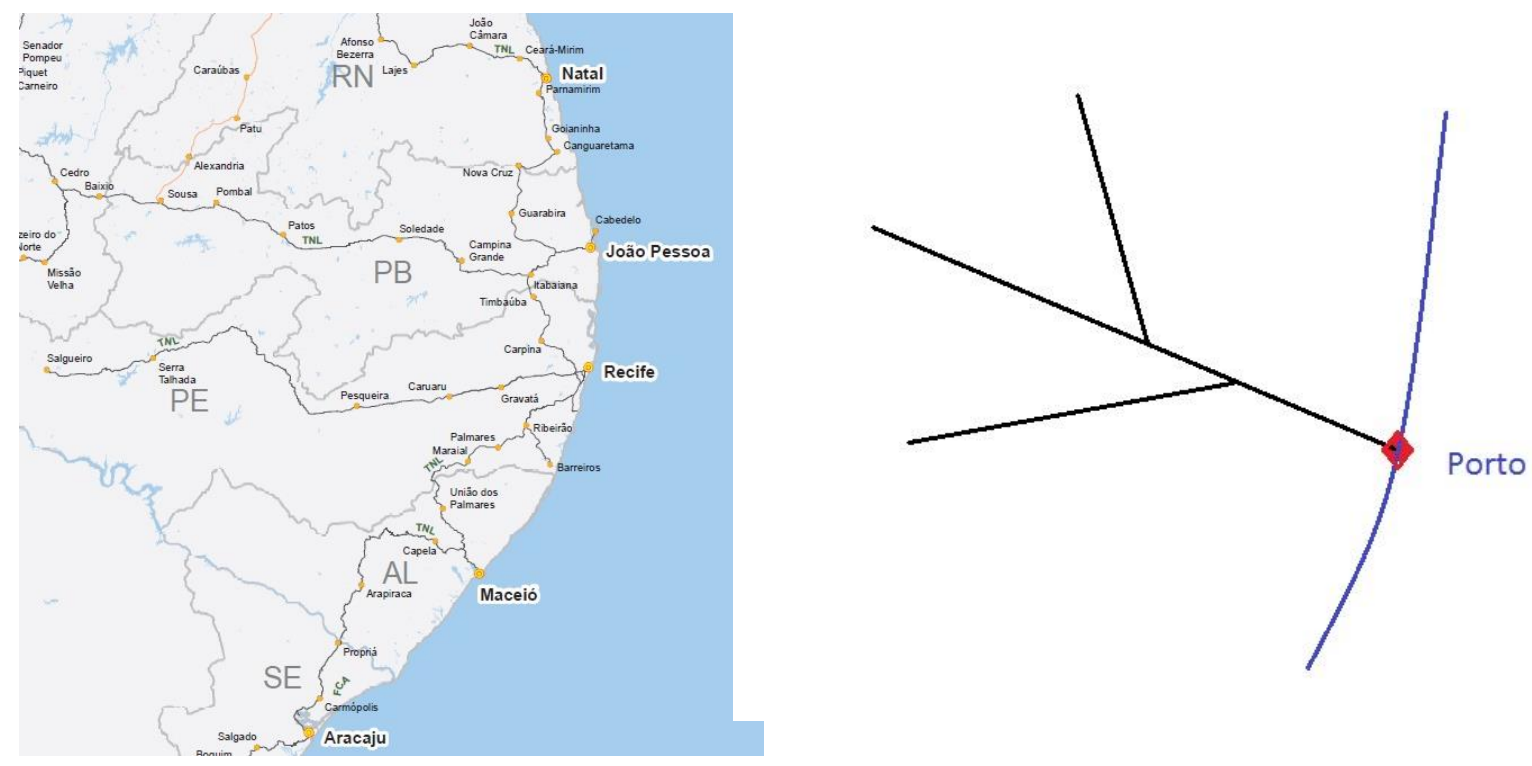

Figura 4.4 Padrão topológico de conexão ferroviária voltado para exportação sem competição para o mercado interno

Mesmo fisicamente conectadas, o padrão topológico das ferrovias brasileiras é voltado para a exportação, em prejuízo das conexões aptas ao desenvolvimento de concorrência entre portos e entre Estados da Federação.

\subsubsection{Abandono de Ramais.}

Como dito anteriormente, apesar da informação oficial de que a extensão da malha ferroviária é de 30.6 mil km (Brasil, 2017), a rede em operação, em 2017, é de pouco mais de 20 mil km. Os trechos abandonados ou subutilizados são consequência da incompatibilidade entre os resultados operacionais esperados, ao longo de sua exploração, e as despesas com os investimentos demandados pelas exigências de execução do contrato.

Muitas das linhas férreas foram subutilizadas justamente porque perderam competitividade na comparação com o modo rodoviário, com a ocupação urbana irregular dos terrenos lindeiros à faixa de domínio ferroviário e, até mesmo, da ocupação da própria faixa, que provocaram a redução da velocidade das composições e aumentaram o risco de acidentes em níveis insustentáveis. 
Em 2011, a ANTT identificou trinta e três trechos abandonados ou subutilizados e fixou prazo para apresentação de cronograma de recuperação pelas concessionárias. Uma síntese dos ramais abandonados pode ser observada na tabela 4.3.

Tabela 4.3 Ramais abandonados ou inoperantes por concessionária em 2011 e 2017

\begin{tabular}{|c|c|c|c|c|}
\hline \multirow{3}{*}{ Concessionária } & \multicolumn{2}{|l|}{$(2011)$} & \multicolumn{2}{|c|}{$(2017)$} \\
\hline & Abandonados & Concessionária & \multicolumn{2}{|c|}{ Inoperantes } \\
\hline & \multicolumn{2}{|l|}{ Extensão (km) } & Extensão (km) & Percentagem \\
\hline Transnordestina Logística & 1.623 & Transnordestina (FTL) & 3.060 & 71,26 \\
\hline ALL Malha Paulista & 650 & Rumo-ALL (MP) & 940 & 45,75 \\
\hline ALL Malha Oeste & 309 & Rumo-ALL (MO) & 722 & 36,61 \\
\hline \multirow[t]{4}{*}{ ALL Malha Sul } & 1.716 & Rumo-ALL (MS) & 2.223 & 30,77 \\
\hline & & Vale (VM) & 247 & 27,72 \\
\hline & & VLI (FNS) Norte & 127 & 17,17 \\
\hline & & MRS Logística & 234 & 13,92 \\
\hline Ferrovia Centro-Atlântica & 1.246 & VLI (FCA) & 976 & 13,51 \\
\hline
\end{tabular}

Fonte: Revista Ferroviária (2017); ANTT (2017).

Desde então, a situação não melhorou. Os $5.544 \mathrm{~km}$ de ramais ferroviários identificados como abandonados ou subutilizados pela ANTT, em 2011, passaram a ser $8.534 \mathrm{~km}$, classificados como "não operacionais", na autodeclaração das concessionárias, prestadas à ANTT, em 2017. Na malha da Transnordestina, por exemplo, 71,26\% dos ramais não estavam operacionais. O único ramal que se mantinha operacional, informado na Declaração de Rede de 2017 (ANTT, 2017), era a ligação São Luís - Teresina - Fortaleza, indicado com uma seta, na figura 4.5. Todos os demais ramais são declarados "não operacional", como pode ser observado na ilustração da figura 4.5. Na malha da Rumo-ALL (malha paulista) onde 45,75\% do total não se encontra em operação, o percentual de ramais inoperantes na bitola métrica é de 97,57\%. Esse fenômeno é uma evidência da falha provocada pela agregação geográfica indiscriminada de ramais sob o comando de uma mesma firma. $\mathrm{Na}$ ausência de competição intramodal, a concessionária pode focar sua atividade nos ramais mais lucrativos, mantendo cativos e inoperantes os ramais que potencialmente lhe fariam concorrência, se estivessem na posse de outras firmas. $\mathrm{O}$ abandono de ramais é uma consequência do processo de licitação por regiões geográficas sob a gestão das antigas superintendências da RFFSA, mas que foi agravado pela omissão da regulação ao permitir a aglutinação ${ }^{49}$ das concessionárias em um menor número de firmas.

\footnotetext{
${ }^{49}$ Em 1998, houve a fusão entre a FERRONORTE e NOVOESTE formando a Brasil Ferrovias. Em 2002, a Brasil Ferrovias incorpora a FERROBAN. Em 2005, a Brasil Ferrovias se separou em dois grupos, um corredor
} 


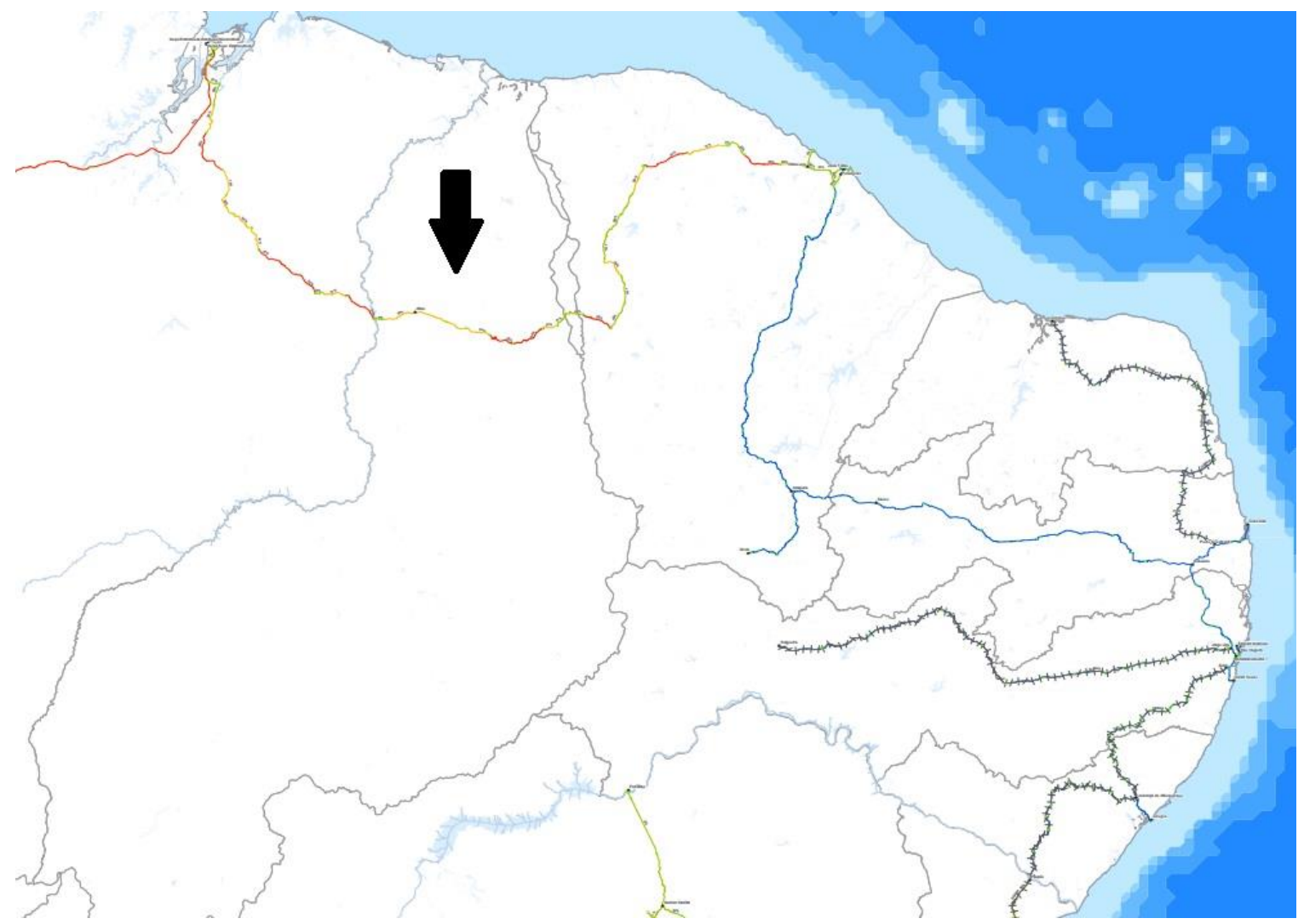

Figura 4.5 Ramais inoperantes na malha da concessionária Transnordestina Logística, em 2017. Fonte: ANTT (2017)

Para solucionar a questão, Felix e Cavalcante Filho (2017) sugerem que:

as concessionárias poderiam ser incentivadas a atuar na exploração de operações urbanas consorciadas ${ }^{50}$, por meio da revitalização da rede para uso de veículos leves sobre trilhos ou de metrô de superfície. A lei deveria prever, então, a possibilidade de reversão de parte dos recursos advindos de contribuição de melhorias $^{51}$, objeto da requalificação dos ramais ferroviários, diretamente para as empresas exploradoras da infraestrutura que implantassem serviços de transporte de passageiros, de maneira a aumentar o leque de atuação das administrações ferroviárias. Essa alternativa de solução produziria receitas não tarifárias, com a exploração imobiliária e comercial de áreas revitalizadas pelo transporte de passageiros, que poderiam ser reinvestidas em ramais para o

de bitola larga, contendo a Malha Norte e a parte da malha Paulista de bitola larga, cujo nome continuou a ser Brasil Ferrovias, e um corredor de bitola métrica, contendo a malha Oeste e a parte da Malha Paulista de bitola métrica, cuja denominação passou a ser Novoeste Brasil. Porém, ambas as firmas continuaram a ter o mesmo grupo controlador. Em 2006, as duas ferrovias foram incorporadas pela ALL. Em 2003, a VALE assume o controle acionário da FCA e, em 2007, a VALE assume a concessão da Ferrovia Norte-Sul Tramo Norte (Benini, 2012)

${ }^{50}$ Operações urbanas consorciadas é um instrumento do Direito Urbanístico instituído pelos artigos 32,33 e 34 do Estatuto da Cidade (Lei no 10.257, de 10 de julho de 2001).

${ }^{51}$ Contribuição de melhoria é um tributo cuja obrigação tem por fato gerador uma situação que representa a valorização imobiliária auferida pelo contribuinte pela realização de uma obra pública, previsto no art. 145, III, da Constituição Federal. 
transporte de cargas. Ter-se-ia, assim, uma situação de ganha-ganha para o transporte de passageiros e de carga ${ }^{52}$.

A ANTF vem, há muito, apontando as invasões nas faixas de domínio, o conflito de fluxo nas passagens em nível e as deficiências de traçado como problemas prioritários do setor ferroviário (Lang, 2007). Sua solução, além do interesse econômico evidente, também tem relevante interesse social envolvido, pois representam a melhora da qualidade de vida das comunidades afetadas, ao diminuir externalidades negativas tais como os acidentes nos cruzamentos e os congestionamentos urbanos. Como, na maioria dos casos, as ferrovias vieram primeiro que as rodovias, os contratos atuais não previram essas obras como obrigações dos concessionários. No entanto, o Estado tem dificuldades, e de natureza não apenas fiscal, para executar obras públicas. Assim, seria oportuno que houvesse, além de programas públicos ${ }^{53}$ para remoção desses gargalos, meios para que as concessionárias ferroviárias pudessem fazer a desobstrução dos ramais, custeadas por financiamento público oriundo de taxação pigouviana ${ }^{54}$ do setor rodoviário e ferroviário (Felix e Cavalcante Filho, 2016).

\subsection{FALHAS DE FINANCIAMENTO}

O financiamento é ponto crucial do desenvolvimento ferroviário, sem financiamento não haverá atualização, menos ainda expansão da infraestrutura e do transporte ferroviário. A indústria ferroviária é, tradicionalmente, correlacionada a custos afundados, longos prazos para recuperação do capital. Mas o problema não é só esse. Insuficiência de investimentos e restrições ao desenho do negócio também estão correlacionados ao caso brasileiro.

\subsubsection{Longo Prazo para Recuperação}

Miranda e Silva (2013) descreve o problema do financiamento em infraestrutura no Brasil nos seguintes termos:

altos custos de entrada e saída dos investimentos, nos longos períodos de maturação, na operacionalização por meio de indústrias de rede, fazendo-se

\footnotetext{
${ }^{52}$ Para maiores informações sobre a estratégia de financiamento de transporte de passageiros, consultar Suzuki et al (2015). Financing Transit-Oriented Development with Land Values Adapting Land Value Capture in Developing Countries.

${ }^{53}$ Programa Nacional de Segurança Ferroviária em Áreas Urbanas (Prosefer) é um estudo que indica as obras necessárias para garantir mais segurança à população, especialmente onde há ocupação de faixas de domínio das ferrovias e passagens em nível críticas. Entre as obras sugeridas estão a construção de variantes e contornos ferroviários para eliminar os gargalos, efetivando etapa do Plano de Revitalização das Ferrovias, lançado em 2003.

${ }^{54}$ Taxação pigouviana é uma espécie de tributação aplicada a uma atividade de mercado que esteja gerando externalidades negativas.
} 
necessária a construção de uma grande estrutura física (funcional) para a provisão destes serviços sendo que, uma vez construída, a estrutura deve ser partilhada pelos ofertantes de serviços a ela associados (o que retira o interesse na obra) e, por fim, o pagamento do negócio e a incerteza de receitas (em virtude de risco intrínseco às grandes obras), o que resultam, muitas vezes, em vencimentos mais longos das dívidas, média alta de índices de endividamento total sobre patrimônio líquido, baixa competitividade e baixa concorrência de mercado.

Embora o excerto acima tenha sido produzido para a infraestrutura em geral e para o Brasil em particular, é possível generalizá-lo globalmente em termos de exploração ferroviária. As diferenças residirão na capacidade de financiamento dos entes internacionais e da capacidade de endividamento dos exploradores ou operadores em particular. Carneiro (2011) apontava que quatro das concessionárias ferroviárias brasileiras tinham risco de insolvência igual ou pior que moderado em 2009.

Em um quadro em que as concessionárias ferroviárias podem não ter a saúde financeira necessária para obtenção de grandes empréstimos por meio de Corporate Finance, o Project Finance seria a solução para o financiamento dos projetos.

Para solução da questão do financiamento e mitigação dos riscos de compartilhamento Pompermayer e Silva Filho (2016) sugerem a adoção de um modelo de Project Finance em que o poder público remunera desde o início da exploração a disponibilidade de infraestrutura pelo parceiro privado e é remunerado por ele em função do aumento da demanda. Mesmo esse modelo inovador, ainda não resolve duas questões fundamentais do equilíbrio econômico-financeiro dos projetos ferroviários: qual é o limite das receitas ferroviárias? O Estado é capaz de realizar investimentos frente ao crescente crescimento das despesas constitucionais obrigatórias?

\subsubsection{Insuficiência de Fontes de Financiamento}

A partir dos dados de investimentos e receitas elencados na legislação orçamentária brasileira é possível observar que nominalmente os transportes possuem fontes razoáveis de financiamento no Brasil, mas o investimento tem ocorrido em montantes muito a baixo do que é preconizado com suficiente para manutenção do capital fixo, como pode ser observado na figura 4.6. 


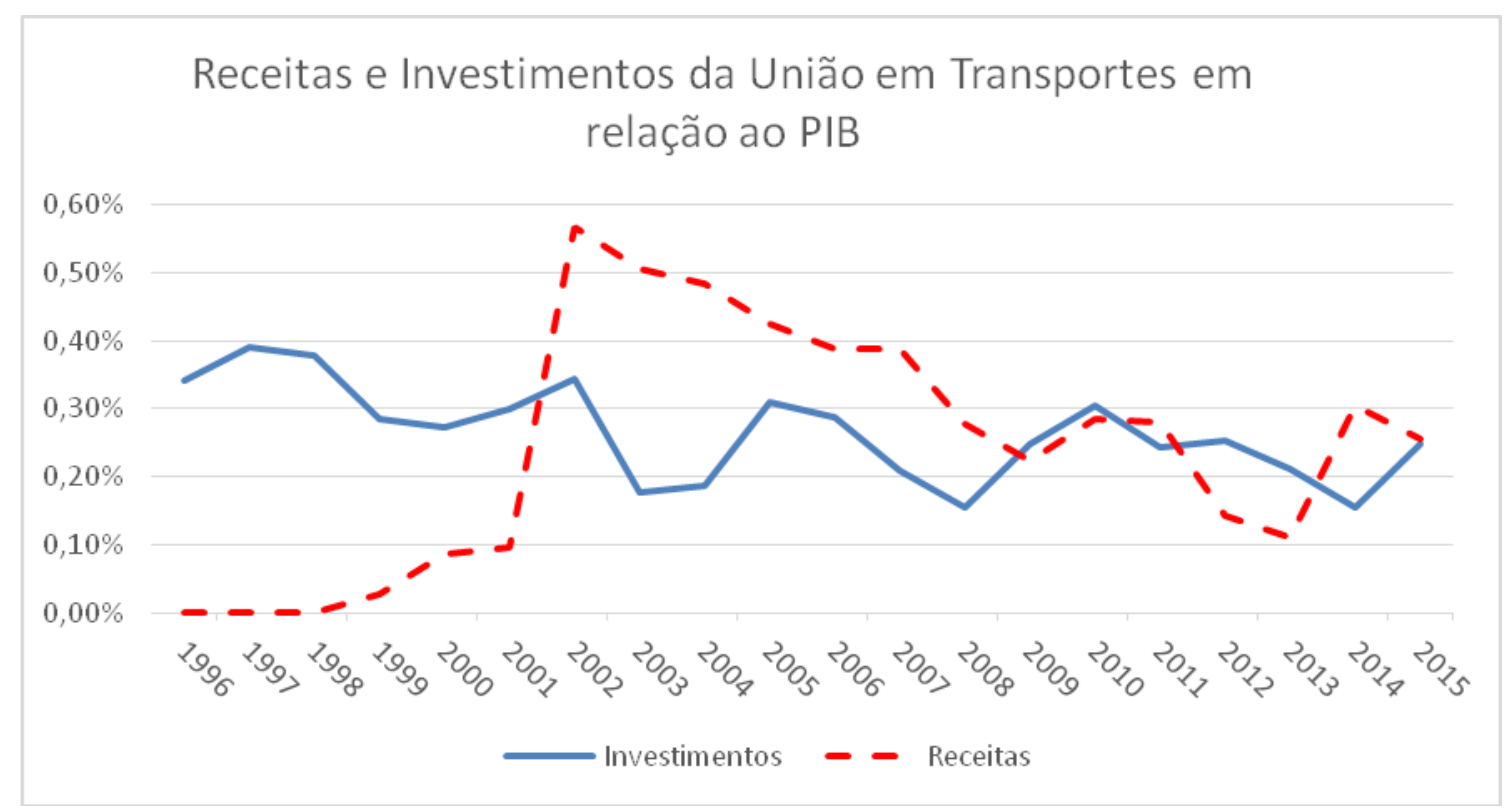

Figura 4.6 Variação das receitas e investimentos da União em Transportes, segundo as leis orçamentárias entre 1996 e 2015

Fonte: Senado (2016)

Os dados orçamentários demonstram que o ano de 2002 representou um marco significativo no equilíbrio das receitas e despesas relacionadas ao setor de transportes. Com a implantação da Contribuição de Intervenção no Domínio Econômico (CIDE), criada pela Lei ${ }^{\circ}{ }^{\circ} 10.336$, de 19 de dezembro de 2001, as receitas passaram a superar os investimentos.

No entanto, as receitas da CIDE passaram a sofrer sucessivas regressões ao longo dos anos seguintes em decorrência de políticas de redução dos preços de combustíveis. Em 2012, o Decreto $\mathrm{n}^{\mathrm{o}} 7.764$ reduziu a zero a alíquota de todos os produtos com possível incidência do tributo. Em 2016 eram tributados apenas a gasolina, o diesel e seus respectivos correntes.

Desde a criação da CIDE, as principais fontes ${ }^{55}$ de receita foram: a própria CIDE; o Adicional ao Frete para Renovação da Marinha Mercante (AFRMM); o Adicional sobre Tarifa Aeroportuária (ATAERO); as multas de trânsito; e os valores oriundos das outorgas dos serviços de infraestrutura aeroportuária. Essas cinco fontes de receitas representam pouco mais de $95 \%$ do montante acumulado nos últimos catorze anos. As demais doze fontes de receitas, de alguma forma vinculadas ao Orçamento da União, aglutinam pouco menos de 5\% das receitas no mesmo período.

Nos últimos quatorze anos, desde 2002, portanto, a média de receitas oriundas da atividade transportes foi de 0,33\% em relação ao PIB. Apenas a CIDE entre os anos de 2002 e 2006

\footnotetext{
${ }^{55}$ A principal fonte de receita do setor de transportes é o Orçamento da União. As fontes aqui elencadas não têm destinação vinculada exclusivamente para o setor de infraestrutura de transportes. Foram elencadas por serem originadas da atividade econômica.
} 
arrecadou cerca de $0,40 \%$ do PIB. O entrave principal não é financeiro, mas de má alocação dos recursos e desperdício de oportunidades.

O investimento incluindo os setores público e privado, em 2015 , ficou em cerca de $0,6 \%$ do PIB. Os países em desenvolvimento que concorrem com Brasil, como Rússia, Índia, Coreia do Sul, Chile e Vietnã, estão investindo uma média de 3,7\% do PIB em transporte (Borges, 2016).

O subinvestimento atual é significativo quando confrontado com o praticado nas últimas décadas. Os investimentos em infraestrutura de transportes passaram por contração de $27 \%$ na década de 1980 e mais 57\% na década de 1990. Assim, quando comparada a década de 2000 à de 1970, os investimentos da última década tiveram redução média de $68 \%$, conforme apresentado na tabela 4.4 .

Tabela 4.4 Investimento em infraestrutura de transportes no Brasil (\% do PIB)

\begin{tabular}{lcccc}
\hline & $\mathbf{1 9 7 1 - \mathbf { 1 9 8 0 }}$ & $\mathbf{1 9 8 1}-\mathbf{1 9 9 0}$ & $\mathbf{1 9 9 0 - \mathbf { 2 0 0 0 }}$ & $\mathbf{2 0 0 1 - 2 0 1 0}$ \\
\hline Transportes & 2,03 & 1,48 & 0,63 & 0,64 \\
\hline
\end{tabular}

Fonte: Frischtak (2013)

Uma análise dos investimentos, públicos e privados, por modo e ano na última década apontam para a predominância do modo rodoviário sobre todos os demais, conforme se depreende da tabela 4.5. Na média, investiu-se quatro vezes mais em rodovias que em ferrovias no período de 2001 a 2010. O auge dos investimentos se deu em 2010, muito por conta do Programa de Aceleração do Crescimento (PAC).

Tabela 4.5 Investimentos em infraestrutura no Brasil, 2001 - 2010 (\% do PIB)

\begin{tabular}{lccccccccccc}
\hline & 2001 & 2002 & 2003 & 2004 & 2005 & 2006 & 2007 & 2008 & 2009 & 2010 & Média \\
\hline Rodoviário & 0,46 & 0,35 & 0,24 & 0,25 & 0,32 & 0,38 & 0,35 & 0,48 & 0,64 & 0,67 & 0,41 \\
Ferroviário & 0,07 & 0,05 & 0,07 & 0,10 & 0,16 & 0,12 & 0,12 & 0,17 & 0,11 & 0,15 & 0,11 \\
Metroviário & n.d. & n.d. & n.d. & n.d. & n.d. & n.d. & 0,04 & 0,08 & 0,15 & 0,08 & 0,09 \\
Aeroportos & 0,04 & 0,04 & 0,04 & 0,03 & 0,03 & 0,04 & 0,02 & 0,01 & 0,01 & 0,02 & 0,03 \\
Portos & 0,03 & 0,03 & 0,01 & 0,03 & 0,02 & 0,03 & 0,04 & 0,04 & 0,05 & 0,05 & 0,03 \\
Hidroviário & 0,02 & 0,01 & 0,00 & 0,01 & 0,01 & 0,01 & 0,01 & 0,01 & 0,02 & 0,01 & 0,01 \\
Investimento/PIB & 0,62 & 0,48 & 0,36 & 0,42 & 0,54 & 0,58 & 0,58 & 0,79 & 0,98 & 0,98 & \\
\hline Fonte: Frischtak (2013) & & & & & & & & & & &
\end{tabular}

Mesmo que a União venha a investir, nos anos vindouros, $0,5 \%$ do PIB em infraestruturas de transportes, se não houver uma seleção apropriada dos investimentos, um dos problemas principais, que é o desequilíbrio da matriz de transportes, não será resolvido. 
Além de o governo federal investir mais, é preciso também criar condições para que o setor privado invista em infraestruturas de transportes, principalmente o ferroviário. Para tanto, fazse oportuno mitigar os riscos de insegurança jurídica dos investimentos privados no setor de transportes, um dos grandes entraves a novos investimentos, como aponta a literatura especializada.

O histórico das economias emergentes bem-sucedidas mostra que os investimentos em infraestrutura têm um papel decisivo na modernização do país, devendo se situar em níveis elevados. Assim, mesmo um investimento de $0,5 \%$ do PIB em transporte pode ser pouco para o Brasil, ainda que isso represente quase dobrar os investimentos federais praticados na média dos últimos dez anos, como apresentado na tabela 4.6.

Tabela 4.6 Investimentos Federais em Transportes no Brasil, 2006-2015 (\% do PIB)

\begin{tabular}{llllllllllll}
\hline & 2006 & 2007 & 2008 & 2009 & 2010 & 2011 & 2012 & 2013 & 2014 & 2015 & Média \\
\hline $\begin{array}{l}\text { Despesa Liquidada } \\
\begin{array}{l}\text { Orçamentária na } \\
\text { Função Transporte }\end{array}\end{array}$ & 0,29 & 0,21 & 0,15 & 0,25 & 0,30 & 0,24 & 0,25 & 0,21 & 0,15 & 0,25 & 0,23
\end{tabular}

Fonte: Senado (2016).

O Banco Nacional do Desenvolvimento Econômico e Social (BNDES) desempenhou papel fundamental no financiamento das concessionárias de ferrovias nos últimos anos. No entanto, no atual cenário de crise fiscal, o financiamento inteiramente público não é uma opção. Não obstante, Felix e Cavalcante Filho (2016), defendem que ainda existem fontes públicas que poderiam ser incluídas para revitalização do Fundo Nacional de Investimentos Ferroviários ${ }^{56}$. Entre elas estariam parcela das receitas provenientes de multas aplicadas a infrações de trânsito em vias federais (taxação pigouviana), multas por descumprimento dos contratos de concessão ferroviária, contribuição de melhoria por obras ferroviárias para transporte de passageiros, contribuição de intervenção no domínio econômico incidente sobre a importação e a comercialização de combustíveis, outorga das concessões ferroviárias, arrendamento dos ativos vinculados às concessões ferroviárias, tarifas ferroviárias e alienação de ativos vinculados às concessões ferroviárias, notadamente na exploração imobiliária de projetos associados.

\subsubsection{Insuficiência de Fontes de Receitas}

Uma forma alternativa de minimizar a necessidade de financiamento público é viabilização de opções alternativas de receitas para as administrações ferroviárias, além das tarifas, a fim de

\footnotetext{
${ }^{56}$ Criado pela Lei no 4.102 , de 20 de julho de 1962.
} 
que o negócio ferroviário torne-se mais rentável, podendo vir a ser financiado pelo mercado, tanto por iniciativas de corporate finance, quanto de project finance.

Como os contratos de concessão ferroviária, dos anos 1990, previram que os investimentos na superestrutura ferroviária não seriam considerados indenizáveis pelo valor residual, ao final de sua vigência, os concessionários têm entendido que os dispêndios com a revitalização são maiores que os benefícios esperados.

Assim, para que a rede subutilizada seja revitalizada, os concessionários precisarão de mais prazo para amortização dos investimentos, efeito que pode ser alcançado pela prorrogação antecipada dos contratos. Todavia, apenas este caminho pode não ser suficiente. Aliás, a prorrogação antecipada dos contratos pode resultar na diminuição da concorrência, em razão da crescente oligopolização geográfica das concessionárias.

As concessionárias poderiam ser incentivadas a atuar no mercado de passageiros, a fim de aumentar suas fontes de receita (Felix \& Cavalcante Filho, 2016).

O aumento da receita pode ser incentivado pela ampliação das fontes acessórias, como, por exemplo, a exploração imobiliária dos domínios arrendados com estratégias de Transit Oriented Development $\left(\mathrm{TOD}^{57}\right)$ no fomento ao transporte de passageiros, nos ramais que atualmente se encontram abandonados ou subutilizados no transporte de cargas (Felix e Cavalcante Filho, 2016).

Segundo Suzuki et al. (2015), a MTR Corporation, firma responsável pela exploração do transporte ferroviário de Hong Kong, é uma empresa lucrativa justamente porque consegue capturar a elevação do valor da terra no entorno de suas estações de metrô. Entre 2000 e 2012, apenas 34\% das receitas da MTR Corporation eram fruto da receita direta com tarifas de transporte. Todo o restante da receita era produto de receitas assessórias, na seguinte proporção: $38 \%$ projetos imobiliários associados; $15 \%$ receitas comerciais das estações de passageiros; $13 \%$ das receitas de aluguéis e gerenciamento de negócios associados.

Importante observar que Hong Kong figura em $2^{\mathbf{o}}$ lugar no ranking de qualidade da infraestrutura ferroviária de WEF (2017), sendo eminentemente uma empresa pública, de atuação monopolista, organizada em sistema de agregação vertical. A Suíça, cuja exploração ferroviária também se dá por ação monopolista estatal e que atualmente figura em primeiro lugar no ranking de qualidade da infraestrutura ferroviária do WEF (2017), no período de

\footnotetext{
${ }^{57}$ O Desenvolvimento Orientado pelo Trânsito (TOD) é uma abordagem de planejamento orientada para centros de negócios e habitação de alta concentração e uso misto que vão ser aglomerados em torno das estações e ao longo dos corredores de transporte de alta capacidade. TOD é considerado uma estratégia do "crescimento inteligente" porque coordena os usos da terra e dos transportes, de modo a que tanto a terra como a infraestrutura sejam eficientemente usadas (Dragutescu, 2006).
} 
2002 a 2011, aumentou os subsídios no transporte ferroviário em 19,7\%. Em 2013, os subsídios chegaram a quantia de 591 milhões de francos suíços, cerca de 1,6 bilhão de reais ${ }^{58}$ (Desmaris, 2014).

O Japão, terceiro colocado no mesmo ranking, segundo Suzuki et al. (2015), também aplica a estratégia de financiamento por receitas assessorias. Suzuki et al. (2015) citam mais dois exemplos. Tokyo Corporation, maior companhia ferroviária privada da região metropolitana de Tóquio no período de 2003 a 2012 faturou com receitas de tarifas de transportes apenas $41 \%$ de suas receitas. O restante da receita foi decorrente de: $34 \%$ receitas imobiliárias, $15 \%$ receitas de serviços residenciais, $5 \%$ de receitas com hotelaria e 5\% com outras receitas. East Japan Railway Company, maior companhia ferroviária de passageiros, no período de 2001 a 2012, obteve $71 \%$ da receita diretamente com tarifas de transporte, mas $15 \%$ de sua receita veio da exploração imobiliária de shopping centers de sua propriedade, $8 \%$ do aluguel de espaços em suas estações de passageiros e $5 \%$ de outras fontes de receita.

À luz da experiência internacional, há evidências de que o investimento privado é uma solução possível para a ampliação dos recursos no setor ferroviário no Brasil. Apesar da fragilidade do marco legal, a iniciativa privada tem investido mais na manutenção e revitalização da malha concedida que todo o investimento federal no setor, como visto na figura 4.7. Entretanto, para que o mercado aumente seus investimentos, é preciso facilitar o acesso ao crédito, melhorar o retorno dos investimentos e propiciar um ambiente institucional favorável, a partir do aprimoramento do marco normativo e regulatório (CNT, 2015). A ausência de regras claras e bem definidas acaba, muitas vezes, por afastar os investidores.

\footnotetext{
${ }^{58}$ Cotação de 7 de 12 de 2017, 1 CHF = 3,3087 R\$.
} 


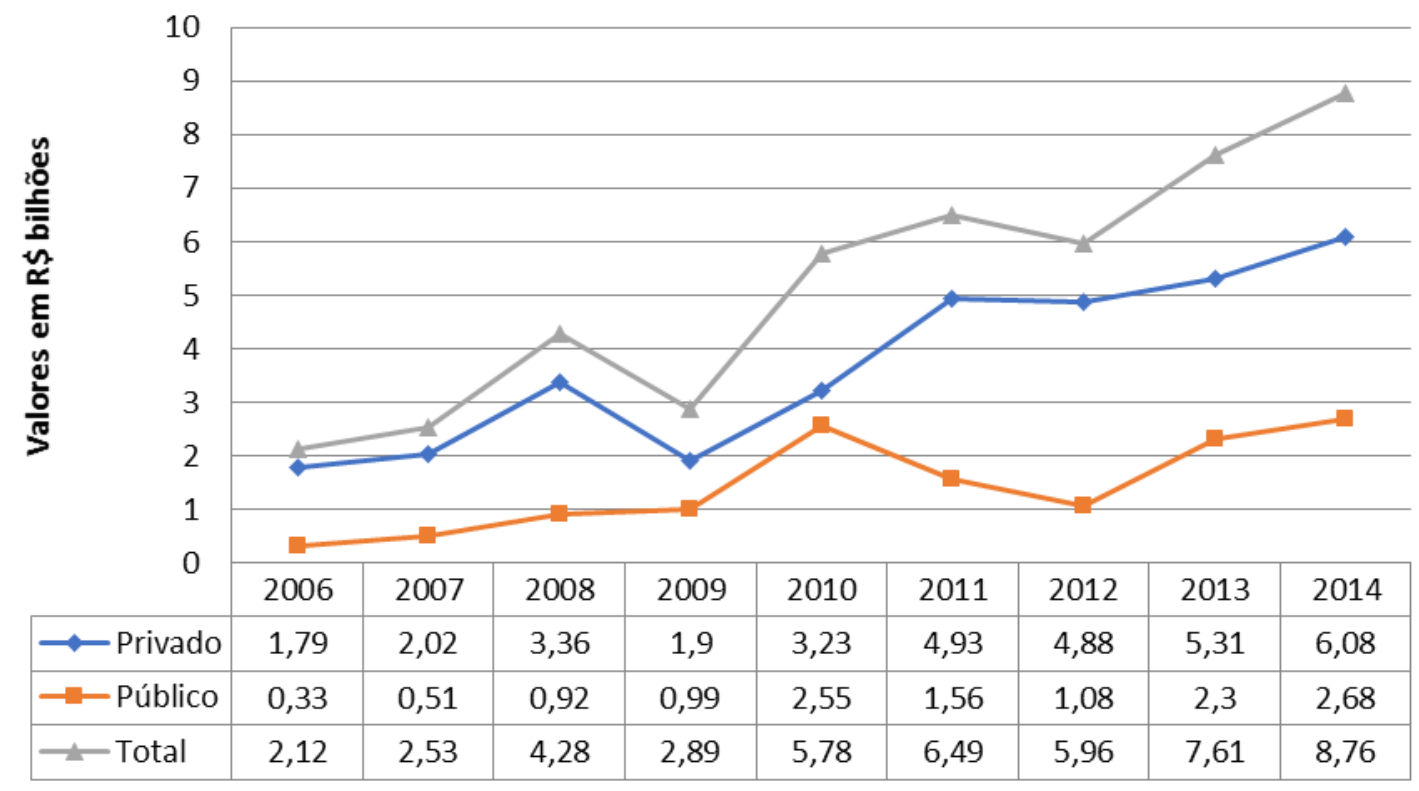

Figura 4.7 evolução dos investimentos em ferrovias: privado (concessionárias) e público (federal), entre 2006 e 2014

Fonte: $\mathrm{CNT}^{\mathbf{5 9}}, 2015$.

Os indicativos que apontam para a viabilidade da modalidade de financiamento inteiramente privada no País são relevantes. Baixíssima densidade da malha ferroviária, desequilíbrio da matriz de transportes, existência de novos TUP em construção, excesso de recursos financeiros disponíveis no mercado internacional e evidências de interesse internacional, notadamente, chinês (Senado, 2017), russo (SEP, 2016) e coreano (Pelegi, 2017), na exploração das ferrovias do Programa de Investimento em Logística, entre outros.

Quanto mais estreito e regulado economicamente for o modelo de exploração da infraesturua ferroviária, mais difícil será o financiamento como sugerem os efeitos do Staggers Rail Act de 1981 nos EUA. Contrario senso o Brasil optou por um modelo bem restrito do alcance das receitas ferroviárias, chegando, por exemplo, a vedar algumas receitas acessórias, nos contratos de concessão.

A China no outro extremo maximizou as fontes de receitas disponíveis às empresas ferroviárias. As empresas ferroviárias chinesas não exploram apenas a infraestrutura ou operação dos trens. Ao contrário, as empresas chinesas ${ }^{60}$, a exemplo da China Railway Eryuan Engineering Group CO. são holdings que exploram todo o ciclo da operação dos trens, desde os levantamentos topográficos preliminares, a construção dos ramais, a construção dos trens, a exploração da infraestrutura e principalmente a exploração imobiliária no entorno das linhas e estações (CREEC, 2016). Essa concepção monopolista altamente

\footnotetext{
${ }^{59}$ Valores referentes ao ano de 2015.

${ }^{60}$ A maioria das empresas chinesas são estatais subordinadas à China Railway Corporation, sucessora do Ministry of Railways (Yin-Nor, 2015).
} 
verticalizada, favorecida por financiamento estatal abundante favorece a constituição de estratégias de corporate e project finance.

Todavia, o histórico internacional evidencia que o desenvolvimento ferroviário não depende apenas de subsídios públicos. Atualmente estão em curso iniciativas privadas para introduzir rotas de trens de alta velocidade nos Estados Unidos. Uma das mais avançadas é o projeto All Aboard Florida, que pretende ligar Miami, Fort Lauderdale, West Palm Beach e, eventualmente, Orlando por uma empresa privada, financiada integralmente pela rentabilidade do projeto, sem financiamento público federal ou estadual. Na China, o astronômico crescimento da rede de Trens de Alta Velocidade subsidiado pelo Estado sugere que o sistema pode não ser financeiramente sustentável em longo prazo (Hui, 2016), assim como também não o foi o crescimento americano fartamente subsidiado pela concessão de imóveis públicos.

\subsection{FALHAS DE MERCADO}

Segundo a Associação Nacional dos Transportadores Ferroviários (ANTF), os investimentos privados das empresas concessionárias promoveram, entre 1997 e 2014, aumento de 117\% na produção do transporte ferroviário, além de obter $4,86 \%$ de taxa de crescimento médio anual, contra uma taxa de crescimento do PIB da ordem de 58,9\%, no mesmo período. Ao mesmo tempo, a gestão e os investimentos da iniciativa privada possibilitaram redução de $84,7 \%$ no número de acidentes ${ }^{61}$. Ainda assim, o mercado ferroviário brasileiro é marcado por significativas falhas de mercado.

Na vigência de falhas de mercado a economia funciona em um modo abaixo do ponto ótimo, em que preços são mantidos acima de preços normais de mercado; oferta e níveis de serviços são mantidos artificialmente a aquém das necessidades da demanda. Segundo Mendes (2011a), o mercado capitalista tende a se autorregular em função de ciclos de preços, a escassez eleva os preços e o aumento de preços induz o fim da escassez. Há, porém, situações em que o mercado tende a não se ajustar sozinho, são as chamadas falhas de mercado.

No mercado ferroviário, falhas de mercado são especialmente danosas para a economia, por ser a indústria ferroviária uma indústria de base. Nesse contexto, as restrições à competição, a natureza de quase bens públicos e as externalidades são falhas que afetam significativamente o mercado ferroviário.

\footnotetext{
${ }^{61}$ ANTF. Balanço do Transporte Ferroviário de Cargas no Brasil de 2013. Brasília, 2014. Disponível em: http://www.antf.org.br/images/2015/pdfs/palestra-2014-antf-balanco-do-transporte-ferroviario-de-2013-versaogustavo-30-09-14.pdf
} 


\subsubsection{Restrições à Competição}

A indústria ferroviária é caracterizada por elevados custos de entrada e de saída. Poucas são as firmas que se dispõem a investir, pois as barreiras econômicas são elevadíssimas. Além das barreiras econômicas, o mercado brasileiro é também marcado por severas barreiras jurídicas que restringem a atuação das firmas. Como resultado, apesar do avanço significativo trazido com a concessão da malha ferroviária, o mercado está concentrado tanto na gestão da malha, quanto nos produtos transportados (Nunes, 2006; Felix e Cavalcante Filho, 2016). Após o processo de concessão das ferrovias, em meados de 1990, a propriedade das ferrovias brasileiras passou, na maioria dos casos, para um rol limitado de seus próprios clientes (Nunes, 2006).

A maior das concessionárias ${ }^{62}$, a América Latina Logística (ALL), foi adquirida pela Rumo, braço logístico do grupo Cosan ${ }^{63,64}$, que atua no mercado de serviços de logística intermodal para exportação de açúcar. Assim, há no mercado um possível conflito de interesses entre as empresas clientes.

Conforme se pode inferir da tabela 4.7, as empresas concessionárias passaram por um processo de oligopolização (Pompermayer, 2016; Felix e Cavalcante Filho, 2016). As concessionárias foram adquiridas por pouquíssimas empresas clientes do transporte de cargas, que, em teoria, poderiam impor restrições às suas concorrentes por meio de obstáculos ao acesso à malha ferroviária. Apenas três empresas, Rumo, VALE e VLI ${ }^{65}$ (Valor Multimodal S.A.), controlam cerca de $75 \%$ das principais estradas de ferro de carga do Brasil, seguidas da Transnordestina Logística S/A e MRS Logística. Juntas, essas cinco firmas ferroviárias controlam a exploração de $95 \%$ da malha ferroviária de cargas do Brasil ${ }^{66}$.

\footnotetext{
${ }^{62}$ A nova companhia, resultante da fusão entre Rumo e ALL, é composta de 4 concessões ferroviárias no Brasil, e surgiu com 12,9 mil quilômetros de malha ferroviária, 19 milhões de toneladas de capacidade de elevação no porto de Santos, 966 locomotivas, 28 mil vagões, e 11,7 mil funcionários diretos e indiretos.

${ }^{63}$ A Cosan é uma das maiores empresas do Brasil, com investimentos em setores estratégicos como agronegócio, distribuição de combustíveis e de gás natural, lubrificantes e logística (Cosan, 2016).

${ }^{64}$ Logo no começo de 2015, o CADE aprovou a fusão denominada ALL-RUMO mediante a incorporação de ações da empresa ALL pela Rumo, onde, para evitar que a Cosan, dona da Rumo, controlasse a ferrovia da ALL e impedisse o uso da estrada de ferro por concorrentes, elevando os preços de frete, foram acordados diversos remédios comportamentais também em sede de Acordo em Controle de Concentração.

${ }^{65}$ Organizada em forma de holding, a VLI tem em sua composição acionária as seguintes empresas: Vale, Mitsui, FI-FGTS, e Brookfield. A Vale além do controle de suas próprias ferrovias também tem poder de decisão em duas outras importantes ferrovias.

${ }^{66} 1.411 \mathrm{~km}$ de linhas férreas de passageiros, entre metrô e trens regionais, não estão incluídas no cômputo da Tabela 4.7.
} 
Tabela 4.7 Principais concessionárias ferroviárias, em 2017

\begin{tabular}{|c|c|c|c|c|c|}
\hline \multirow{2}{*}{$\begin{array}{l}\text { Concessionária Original } \\
\text { Ferrovia NOVOESTE S.A. }\end{array}$} & \multirow{2}{*}{$\begin{array}{l}\text { Concessionária Atual } \\
\text { Rumo - ALL (Malha Oeste) }\end{array}$} & \multirow[t]{2}{*}{ Controlador } & \multicolumn{2}{|c|}{$\begin{array}{l}\text { Extensão } \\
\quad(\mathbf{k m})\end{array}$} & \multirow[t]{2}{*}{$\begin{array}{c}\text { Extensão } \\
(\%)\end{array}$} \\
\hline & & & 1.973 & & \\
\hline FERRONORTE S.A. & Rumo - ALL (Malha Norte) & & 735 & & 4122 \\
\hline Ferrovias Bandeirantes S.A & Rumo - ALL (Malha Paulista) & Cosan e ALL & 2.055 & 11.986 & 41,22 \\
\hline ALL - América Latina do Brasil & Rumo - ALL (Malha Sul) & & 7.223 & & \\
\hline FCA - Ferrovia Centro-Atlântica & VLI (Malha FCA) & Vale, Mitsui, & 7.223 & & \\
\hline $\begin{array}{l}\text { VALEC - Ferrovia Norte-Sul - } \\
\text { Tramo Norte }\end{array}$ & VLI (Malha FNS - Norte) & $\begin{array}{l}\text { FI-FGTS e } \\
\text { Brookfield }\end{array}$ & 745 & 7.968 & 27,40 \\
\hline EFC - Estrada de Ferro Carajás & Vale (Malha EFC) & & 978 & & \\
\hline $\begin{array}{l}\text { EFVM - Estrada de Ferro Vitória a } \\
\text { Minas }\end{array}$ & Vale (Malha EFVM) & Vale & 895 & 1.873 & 6,44 \\
\hline Companhia Ferroviária do Nordeste & $\begin{array}{l}\text { FTL S/A - Ferrovia } \\
\text { Transnordestina Logística }\end{array}$ & CSN & 4.295 & 4.295 & 14,77 \\
\hline MRS - MRS Logística & MRS - MRS Logística & $\begin{array}{c}\text { Vale, CSN, } \\
\text { Usiminas e } \\
\text { Gerdau }\end{array}$ & 1.686 & 1.686 & 5,79 \\
\hline $\begin{array}{l}\text { FERROESTE - Estrada de Ferro } \\
\text { Paraná Oeste }\end{array}$ & $\begin{array}{l}\text { FERROESTE - Estrada de } \\
\text { Ferro Paraná Oeste }\end{array}$ & Gov. Paraná & 248 & 248 & 0,85 \\
\hline FTC - Ferrovia Tereza Cristina & FTC - Ferrovia Tereza Cristina & FTC & 163 & 163 & 0,56 \\
\hline $\begin{array}{l}\text { VALEC - FNS S/A -Ferrovia } \\
\text { Norte-Sul - Tramo Central }\end{array}$ & $\begin{array}{l}\text { VALEC - FNS - Tramo } \\
\text { Central }^{67}\end{array}$ & VALEC & 856 & 856 & 2,94 \\
\hline & Total & & 29.075 & 29.075 & $\mathbf{1 0 0 , 0 0}$ \\
\hline
\end{tabular}

Fonte: ANTT (2017); ANTF (2016); Pompermayer (2016); Felix e Cavalcante Filho (2016).

Segundo Cui \& Besanko (2016), em teoria, a segregação geográfica com integração vertical tende a ser uma melhor opção em relação a agregação geográfica com segregação horizontal. $\mathrm{Na}$ prática, as ferrovias brasileiras passaram de um modelo de segregação geográfica com integração vertical para um modelo de agregação geográfica com integração vertical. A atual oligopolização das ferrovias em grandes regiões geográficas acaba por mitigar os efeitos teóricos positivos do modelo brasileiro criado nos anos 1990.

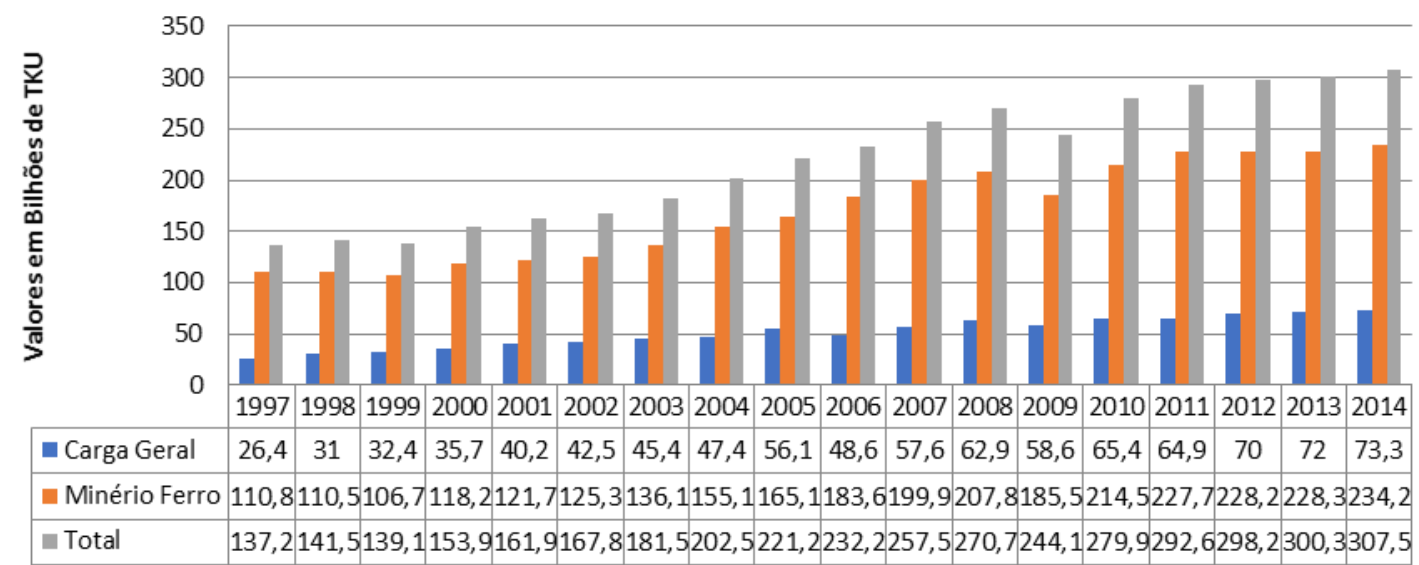

Figura 4.8 Evolução da produção de transporte ferroviário em bilhões de TKU, entre 1997 e 2014 Fonte: ANTF, 2014 e $2015^{68}$.

67 A EF-151 no trecho entre Palmas/TO e Anápolis/GO foi concluída e entregue em 22 de maio de 2014, contudo, ainda não está operacional e deve ser concedida no âmbito do Programa de Parcerias de Investimentos (PPI), conjuntamente com o tramo sul até Estrela D’oeste-SP. 
Como se pode inferir dos dados da figura 4.8, o minério de ferro tem representado em média $76 \%$ dos produtos transportados por ferrovias. Em 2013, produtos do agronegócio ocuparam $13,89 \%$ dos produtos transportados. Na média, menos de $10 \%$ das cargas transportadas é de outros produtos, o que evidencia a incompletude do mercado.

A tentativa do governo Dilma Rousseff de segregar a exploração da infraestrutura da operação da ferrovia tinha a intenção de reduzir as falhas de mercado decorrentes da exploração da atividade em regime de monopólio natural pelas empresas clientes dominantes. As demais empresas clientes poderiam acessar a malha por meio de operadores ferroviários independentes. Todavia, a solução desenhada pelo governo apresentava determinadas falhas intrínsecas que a inviabilizaram completamente.

Em que bases, portanto, se justifica a importância do acesso aos mercados? A teoria dos mercados contestáveis argumenta que a entrada de novos concorrentes, ou apenas a possibilidade concreta de surgimentos de novos entrantes seria suficiente para incentivar os participantes a produzir com eficiência e a preços competitivos, abrindo mão de posturas e de receitas de natureza monopolista (Merker \& Henser, 2014).

Em aberto contrassenso, as empresas concessionárias, no Brasil, não somente gozam dos efeitos da exploração do mercado em regime de monopólio, mas também se beneficiam de fortes restrições, inclusive legais, à entrada de empresas concorrentes. A mitigação dos efeitos do monopólio natural é, por isso, um objetivo importante a ser perseguido, podendo a abertura do mercado ser alcançada com o levantamento as barreiras jurídicas à livre iniciativa privada.

\subsubsection{Natureza de quase Bens Públicos}

Varian (1947) define bem público como aquele que tem de ser fornecido na mesma quantidade para todos os consumidores envolvidos. Uma vez ofertado um bem público, não é possível restringir o consumo, nem o consumir em diferentes quantidades. Como exemplos clássicos de bens públicos, Varian (1947) aponta o meio ambiente e a defesa nacional. Não é possível a um determinado cidadão obter mais ou menos defesa nacional, independentemente de sua propensão a pagar mais ou menos tributos para evitar uma invasão estrangeira, todos os cidadãos recebem a mesma quantidade de defesa nacional. Da mesma forma, o ar puro, o mar limpo são bens que não podem ser consumidos de forma individualizada, independentemente da utilidade que os consumidores precificam esses bens.

\footnotetext{
${ }^{68}$ Há pequenas divergências nos dados da produção dos anos de 2011, 2012 e 2013, entre os balanços de 2014 e 2015 da ANTF.
} 
Bens públicos, por natureza, são propícios a fomentar o efeito carona por parte dos consumidores. Já que não é possível discriminar o consumo, cada consumidor tende a esperar que outro consumidor pague pela provisão do bem. Como resultado, o mercado não tem interesse em prover bens públicos na quantidade desejada (Varian, 1947).

Mendes (2011a) cita estradas de rodagem deficitárias como exemplo de bem público. Mesmo sendo remunerado pelo pedágio, o mercado só terá interesse em construir e operar estradas de rodagem em situações em que o tráfego seja suficientemente elevado. Nesses casos, mesmo com a evasão de receitas dos que pegam carona entrando e saindo da via entre as praças de pedágio, a firma poderá obter lucros recebendo apenas dos que cruzam as praças de pedágio. Obviamente, a oferta de rodovias pedagiadas será sempre menor que a demanda, por ter a rodovia um comportamento de bem público em sentido econômico.

Apesar do comportamento dos consumidores não ser o mesmo nas estradas de ferro em relação as estradas de rodagem, juridicamente, as ferrovias, no Brasil, recebem o mesmo tratamento que as rodovias. É plenamente possível individualizar o consumo de uma estrada de ferro, independentemente do tráfego ser baixo ou elevado, pois não é operacionalmente possível ao consumidor fugir do pagamento da tarifa. Não existe trem grátis.

Por que então ferrovias são tratadas como bens públicos? Sem computar a fundamentação ideológica, possivelmente a fundamentação econômica tem relação com os baixos preços de reserva que os consumidores estão dispostos a pagar pelas ferrovias. O preço de reserva é o preço máximo que o consumidor está disposto a pagar por um determinado bem (Varian, 1947). Como os preços de reserva são naturalmente baixos em função da concorrência com outros modos, aéreo no caso de passageiros, e rodoviário e aquaviário, no transporte de cargas, o tempo de retorno dos investimos é demasiado alto para o nível de exposição ao risco suportado pelas firmas. Quanto maior o tempo de payback maior o tempo de exposição da firma a expropriações, a alterações unilaterais do equilíbrio econômico-financeiro dos contratos ou obsolescência dos próprios negócios.

Como solução dessa falha o governo pode se utilizar de incentivos financeiros, por meio de subsídios ou mesmo participação societária estatal em empresas que constroem e operam estradas de ferro, vide estratégias dos governos Lula e Dilma Rousseff apontadas no item 4.3. Todavia, a solução tendente a gerar o menor gasto público é a liberalização de receitas alternativas e assessórias integradas ao negócio ferroviário. Receitas advindas da exploração imobiliária de shoppings centers, edifícios de escritórios, residenciais e hotéis construídos nos imóveis pertencentes ou associados as firmas ferroviárias. Solução amplamente empregada no 
Japão, China, Hong Kong, Taiwan e mais recentemente nos EUA para mitigar e até mesmo excluir a necessidade de financiamento público.

\subsubsection{Externalidades}

A externalidade é um efeito não desejado pela firma que provê o bem que afeta a produtividade de outras firmas ou consumidores (Varian, 1947; Dalbem et al., 2010). Assim, obviamente a externalidade pode ser positiva ou negativa. Para Varian (1947) a falha está em não existir um mercado para precificar e remunerar externalidades. O modo ferroviário afeta positivamente o meio ambiente por poluir menos comparativamente aos outros modos de transporte, exceto o aquaviário. Ainda assim, as firmas ferroviárias não são remuneradas por isso. As firmas ferroviárias também não são remuneradas por diminuírem o número de acidentes nas estradas de rodagem, por exemplo. O equilíbrio da matriz de transporte em benefício do modo ferroviário provocaria a redução do Custo Brasil, que seria outra externalidade positiva. Todavia, tais externalidades não são tratadas pelo Estado. Uma maneira simples de o fazer seria cobrando taxas pigouvianas para financiar o modo ferroviário, a exemplo do exposto no subitem 4.3.

\subsubsection{Falhas de Coordenação.}

Uma vez que o sistema de mercado é, por natureza, descentralizado, há casos em que a falta de coordenação entre as partes exige que uma entidade de fora do mercado (o governo) intervenha para fazer a devida coordenação (Mendes, 2011a). No setor ferroviário, a proliferação de bitolas é um exemplo de falha de coordenação. A fim de evitar competição de outras ferrovias em sua malha é possível que uma ferrovia procure atuar utilizando uma bitola diversa do restante da malha (Benini, 2012). Essa questão pode ser resolvida consensualmente entre todas as ferrovias, como foi nos EUA (Silva, 1904) ou pode ser imposta pelo Estado, como aconteceu no Reino Unido (Puffert, 2002).

\subsection{FALHAS DE GOVERNO}

$\mathrm{Na}$ área de transportes ferroviários, o Estado tem um papel essencial na liderança e coordenação do planejamento (Bray \& Sayeg, 2013). O planejamento estatal é essencial para propiciar eficiência ao sistema de transportes. Todavia, a atuação do Estado para mitigar ou eliminar falhas de mercado, a fim elevar o nível de bem-estar da população, podem gerar falhas de governo, ou seja, os fatores que podem fazer com que as intervenções do governo gerem distorções maiores que aquelas que ele se propõe a resolver (Mendes, 2011b). Assim, para Mendes (2011b), toda ação governamental deveria ser precedida de uma análise prévia 
sobre as suas vantagens (correção de falhas de mercado) e desvantagens (possíveis falhas de governo decorrentes daquela ação), notadamente, quanto a problemas de: escolha coletiva; agente-principal; inexistência de incentivos à eficiência; e alto custo de transações nas decisões públicas.

\subsubsection{Problemas de Escolha Coletiva}

No interesse de quem o governo escolhe? O interesse público deveria ser o fundamento basilar das escolhas do governo, todavia, a prática demonstra que governo tende a beneficiar o interesse específico de seus eleitores ou financiadores em prejuízo do interesse que maximizaria o interesse coletivo (Friedman \& Friedman, 2015, Mendes, 2011b, 2015). A escolha do interesse público, às vezes, é de difícil aferição em um cenário de extremas deficiências por incompletude de mercado.

Como diferençar, então, por exemplo, se a escolha da construção da Ferrovia de Integração Oeste Leste na Bahia tem menos interesse público que o Ferroanel de São Paulo? São Paulo tem maior mercado e população em relação à Bahia, por outro lado, a redução das desigualdades regionais é um objetivo fundamental da Carta Política da República Federativa do Brasil (art. $3^{\circ}$, III, CF). A alegação de que o governo federal teria beneficiado um Estado da federação em prejuízo de outro por motivação político-partidário seria de dificílima comprovação. O custo desse controle é alto para a sociedade e os benefícios são difusos. Assim, o governo tem incentivos para direcionar, na prática suas escolhas por interesses político-partidários, em que pese, em teoria, justificar suas escolhas por interesse público.

Além disso, a concentração de competências da União no setor ferroviário tende a gerar um efeito carona por parte de Estados e Municípios, que tenderão a esperar que o orçamento federal seja utilizado para a solução de problemas que poderiam, tecnicamente, ser suportados pelos entes federados, em cooperação, em melhores condições do que o realizado pela União. Por exemplo, as estradas de ferro entre Rio de Janeiro e Espírito Santo (EF-118) ou Mato Grosso e Pará (EF-170) são, juridicamente, competência da União, em que pese, tecnicamente, serem de maior interesse local para esses dois Estados da federação. Estradas de ferro tendem a ser mais eficientes quanto maiores forem suas extensões, de maneira que as estradas de ferro mais úteis tendem a ultrapassar as divisas estaduais, atraindo a competência da União. Se a distribuição de competências fosse distribuída concorrentemente com os Estados-federados, os Estados não ficariam dependentes da União. Essas duas ferrovias constaram no PIL, mas, a União só está levando uma delas a frente. Rio de Janeiro e Espírito Santo podem ficar sem o investimento caso a União politicamente decida nunca os atender. 
No modo ferroviário, a escolha coletiva é tomada em uma esfera muito longe do interesse local. A barreira jurídica pode ser maior que a barreira econômica ao investimento ferroviário. A escolha de prioridades não possui transparência adequada, de maneira que os controles sociais são escassos, pois, os custos de fiscalização e monitoramento da sociedade são elevados.

\subsubsection{Problema Agente-Principal}

Os eleitores não têm como monitorar plenamente os políticos eleitos. Além disso, os políticos eleitos não têm como monitorar os servidores que nomeiam para gerenciar as políticas públicas. Por isso, servidores e políticos podem, no exercício da função, buscar os seus objetivos individuais (ampliar poder político, enriquecer, trabalhar pouco, etc). Essa falha é conhecida como problema agente-principal e surge quando as duas partes têm interesses divergentes em ambiente de assimetria de informações (Mendes, 2011b). A assimetria de informações é maior entre cidadãos e reguladores do que entre grupos de interesse e reguladores (Daychoum \& Sampaio, 2017).

Dessa forma, o problema agente-principal é mais grave para os cidadãos do que para as administrações ferroviárias. A rejeição pelo mercado da solução VALEC para a intermediação da capacidade de carga entre operadores e exploradores ferroviários no modelo de open access criado pelo Decreto $\mathrm{n}^{\circ} 8.129$, de 23 de outubro de 2013, é um exemplo prático dessa falha de governo, tanto do problema agente-principal, quanto de sua solução, em razão da menor assimetria de informações entre as partes envolvidas.

No caso, o principal, a União Federal, por meio da Lei $\mathrm{n}^{\circ}$ 11.772, de 17 de setembro de 2008, reestruturou o agente, a VALEC - Engenharia, Construções e Ferrovias S.A., na forma de empresa pública, sob a forma de sociedade por ações controlada pela União e vinculada ao Ministério dos Transportes, para construir, explorar e operar as ferrovias EF-151, EF-267, EF-334 e EF-354 (Art. 5 $, 6^{\circ}, 8^{\circ}$ e $9^{\circ}$ ).

Em 2013, cinco anos após a reestruturação da VALEC, do total de 3.100 km previstos da EF151, entre Belém-PA e Panorama-SP, apenas $764 \mathrm{~km}$, entre Açailândia-TO e Porto Nacional-TO estavam em operação. O trecho operacional, entretanto, não estava sendo explorado pela VALEC, mas sim pela empresa Vale/VLI, por meio de contrato de subconcessão.

Ademais, os cerca de $200 \mathrm{~km}$ iniciais da linha entre Açailândia e Aguiarnópolis, não foi executado pela VALEC. As obras geridas pela VALEC, iniciaram-se entre 2003 e 2006, 
situadas entre Aguiarnópolis-TO e Porto Nacional-TO (TCU, 2014). Ou seja, nem mesmo o trecho operacional, geralmente atribuído à VALEC, fora construído pela VALEC.

Aliás, a União não necessitaria, em tese, da VALEC para construção de estradas de ferro. Historicamente, a União, na administração direta, se valeu do Exército Brasileiro, por meio do $1^{\circ}$ e do $2^{\circ}$ Batalhão Ferroviário, que construíram cerca de $2.500 \mathrm{~km}$ de estradas de ferro, notadamente, ramais nas regiões sul e sudeste e a ligação ferroviária entre Uberlândia-MG e Brasília-DF (EB, 2017a e 2017b).

Na administração indireta, antes da reestruturação da VALEC em 2008, a União já contava, desde 2001, com o DNIT, autarquia legalmente competente para gerenciar a construção, ampliação, restauração e operação de ferrovias federais. Competência que nunca foi extinta, nem mesmo após a reestruturação da VALEC. Note-se que, juridicamente, a competência ferroviária do DNIT é mais ampla que a da VALEC. Nos termos legais ${ }^{69}$, o DNIT tem competência sobre todas as ferrovias federais, enquanto a VALEC tem competências sobre rol limitados de ferrovias. Porém, na prática, a VALEC exerceu maior protagonismo na construção e no projeto dos novos ramais a ela outorgados, enquanto o DNIT manteve-se, notadamente, adstrito à atualização ou à manutenção de ramais ferroviários arrendados as administrações ferroviárias privadas.

Em 2013, quando o Decreto de instituição da política de livre acesso (open access) foi publicado, as demais ferrovias legalmente outorgadas à empresa pública VALEC estavam em atrasados estágios de planejamento e construção, alguns com graves acusações de corrupção e superfaturamento. Se a VALEC não era, essencialmente, necessária para a construção e exploração da rede ferroviária federal, que, legal e tradicionalmente, já vinha sendo construída e explorada por outros órgãos e entidades da administração federal e empresas concessionárias privadas, então, poder-se-ia pensar que o papel principal da nova estatal seria a operação de serviços ferroviários, a exemplo da extinta RFFSA. Todavia, essa atividade foi subconcedida, mediante contrato, à empresa privada Vale/VLI. Assim, para que serveria a empresa VALEC? O interesse do principal ao reestruturar a VALEC era a construção, exploração e operação de um rol específico de estradas de ferro. Finalidade que a VALEC não executa com eficiência.

A análise dos investimentos federais realizados pelo governo no setor ferroviário, para expansão da malha de estradas de ferro, notadamente, nos trechos outorgados à empresa

\footnotetext{
${ }^{69}$ Competências estabelecidas pela Lei ${ }^{\circ} 10.233$, de 5 de junho de 2001 (art. 81 e 83).
} 
pública VALEC, revelam que a União sequer consegue alcançar suas próprias metas físicas (Felix \& Cavalcante Filho, 2016).

Na tabela 4.8, vê-se que os percentuais de $36 \%$ e $24 \%$ de execução, correspondentes ao PPA de 2008-2011 e ao 2012-2015, atestam a incapacidade governamental e setorial de dar efetividade às obras de infraestrutura ferroviária programadas. ${ }^{70} \mathrm{~A}$ realização financeira do PPA 2008-2011 sequer alcançou 50\% do previsto e, no PPA seguinte, embora atingidos 82\% do projetado, foram entregues apenas $24 \%$ da meta física.

Tabela 4.8 Investimentos federais em ferrovias - PPA 2008-2011 e 2012-2015

\begin{tabular}{|c|c|c|c|c|c|c|}
\hline \multirow{2}{*}{ Plano Plurianual (PPA) } & \multicolumn{3}{|c|}{ 2008-2011 } & \multicolumn{3}{|c|}{ 2012-2015 } \\
\hline & Previsto & Realizado & Percentual & Previsto & Realizado & Percentual \\
\hline $\begin{array}{l}\text { Construção de Ferrovias } \\
(\mathrm{km})\end{array}$ & 2.518 & 909 & $36 \%$ & 4.546 & 1.088 & $24 \%$ \\
\hline Recursos (R\$ mil) & 7.530 & 3.082 & $41 \%$ & 10.183 & 8.309 & $82 \%$ \\
\hline
\end{tabular}

Fonte: Peixoto Filho, 2016.

Considerando a ineficiência e superposição de competências da empresa pública, não seria mais econômico para o principal reduzir as competências do agente ou mesmo extingui-lo, a exemplo do que já se havia feito com a RFFSA, com benefícios fiscais e de produtividade? Ao contrário, a escolha do governo foi ampliar as competências da VALEC para um novo campo, nunca explorado pela empresa pública, o de intermediação da capacidade de carga entre as concessionárias ferroviárias e as futuras operadoras ferroviárias. O governo foi convencido pelo agente que o mais adequado a ser feito no interesse do principal era ampliação do orçamento do agente.

Contudo, esse entendimento foi veementemente rejeitado pelas administrações ferroviárias, devido, possivelmente, a menor assimetria de informações. As empresas concessionárias formalmente rejeitaram a solução VALEC em razão do elevado risco fiscal de inadimplência por parte da União em honrar os compromissos.

\subsubsection{Inexistência de Incentivos a Eficiência}

A escolha das prioridades da União, no modo ferroviário é, ao longo dos diversos governos tem sido, aparentemente, motivada por interesses estratégicos e político-partidários, que, em geral, tenderam a gerar aumento de gastos públicos sem a respectiva prestação de serviços públicos. Friedman \& Friedman (2015) explicam o desincentivo a eficiência do gasto público com uma lógica simples: o Estado gasta o dinheiro de terceiros com outros terceiros, o gasto

\footnotetext{
${ }^{70}$ Peixoto Filho, A. P. (2016) Análise dos Programas de Investimentos no Transporte Ferroviário de Cargas: PPA'S 2008/2011 - 2012/2015. Dissertação de Mestrado em Transportes, Publicação T.DM - 021/2016, Departamento de Engenharia Civil e Ambiental, Universidade de Brasília, Brasília, DF, 102 p.
} 
público, por natureza, não tem incentivos para ser econômico nem de qualidade. Para Friedman \& Friedman (2015) o gasto com maior incentivo para ser eficiente é o gasto privado, pois os fundos são do agente econômico gasto com ele próprio.

Veja-se por exemplo, os gastos do governo com projetos de novas ferrovias. Quanto já foi gasto apenas nos projetos do trem de alta velocidade, ferrovia Brasília-Goiânia, BrasíliaLuziânia, Ferroanel de São Paulo? Nenhum desses projetos resultou em efetiva construção das ferrovias. Como não há competição real de nenhum tipo nesse campo, já que o monopólio da iniciativa é estatal, não há incentivos para que os projetos cheguem a um termo razoável, não há sequer termos de comparação da eficiência desses projetos já que nenhum deles chega a ser posto a prova.

Além disso, Friedman \& Friedman (2015) apontam a corrupção como resultado da falta de incentivos a eficiência. O setor ferroviário estatal é cheio de exemplos nesse sentido, tanto no Brasil, com os notórios casos de corrupção da Valec, que resultaram na prisão de seu Presidente, quanto na China, que resultaram na prisão do Ministro Liu Zhijun, sentenciado a morte (Yin-Nor, 2015).

\subsubsection{Baixa Transparência}

O setor ferroviário, assim como os demais de infraestrutura de transportes, sofre por falta de transparência, e não são claras para a sociedade as prioridades do governo e as escolhas que as promoveram. A experiência mais exitosa, nesse campo, se deu com o Plano Nacional de Logística de Transportes (PNLT), que foi editado e atualizado em 2007, 2009 e 2011, sendo posteriormente descontinuado. Por meio do PNLT era possível não apenas ao mercado, mas também à sociedade, estimar quais as motivações e as prioridades do governo. Assim, os agentes econômicos privados podiam direcionar seus investimentos em convergência com o planejamento estatal. Todavia, nos últimos anos, as sinalizações econômicas do governo têm sido contraditórias.

Nesse sentido, o veto aos anexos da Lei ${ }^{\circ}$ 12.379, de 6 de janeiro de 2011, que dispõe sobre o Sistema Nacional de Viação (SNV) foi um duro golpe à transparência do planejamento público no setor de infraestruturas de transportes. O Anexo III, por exemplo, listava 45.469 $\mathrm{km}$ de linhas férreas federais, entre estradas implantadas e planejadas, e foi vetada, alegadamente, por não refletir o planejamento viário nacional. Segundo a Mensagem de Veto, os anexos deixaram de incluir projetos constantes do PNV e fundamentais para o desenvolvimento do País, alguns, inclusive, integrantes do Programa de Aceleração do Crescimento - PAC. 
De fato, os anexos da Lei $n^{\circ}$ 5.917, de 10 de setembro de 1973, que aprovou o Plano Nacional de Viação, apontavam para um total de $51.530 \mathrm{~km}$ de ferrovias implantadas e planejadas, sem contabilizar sete ramais ferroviários que não foram elencados com suas respectivas extensões. A relação descritiva das ferrovias federais poderia ser útil como fundamento para o planejamento transparente de um Plano Nacional de Outorgas de Estradas de Ferro.

Recentemente, o governo tem iniciado um processo de recuperação da transparência. Um marco dessa iniciativa é a divulgação dos dados estatísticos do setor, feito em 13 de junho de 2017, pelo Ministério dos Transportes, Portos e Aviação Civil e a Empresa de Planejamento e Logística, que juntos, lançaram o Anuário Estatístico de Transportes 2010 - 2016.

Extinto em 2002, o GEIPOT (Empresa Brasileira de Planejamento de Transportes) foi o precursor desta iniciativa, mantendo-a por décadas (1970 a 2001). A decisão de reativar o Anuário tem como princípio contribuir para a construção e efetivação de políticas públicas e para o planejamento de transportes. A publicação também possibilita ampliar o conhecimento das atividades do setor pela sociedade, orientando a realização de pesquisas, estudos e análises mais abrangentes, proporcionando melhor compreensão da dinâmica do setor de transportes, bem como o resultado operacional no período, com a exposição de dados consolidados de fontes oficiais (Brasil, 2017).

Se falta transparência no planejamento, esse problema também aflige a regulação do setor. Por mais de três anos, a ANTT não teve sua diretoria completa, por atrasos nas nomeações. O Conselho Nacional de Transportes, desde sua criação, em 2001, pouco se reuniu, e praticamente não atuou no setor de transportes ferroviários.

A transparência no processo decisório tem papel fundamental na legitimação das ações do ente regulador. A partir do momento em que o administrador opta, em adição ao princípio da publicidade, em dar ampla transparência a seus procedimentos internos, ele informa ao público, gera indicadores da qualidade da prestação do serviço e se expõe a todo tipo salutar de controle (Oliveira et al., 2011).

O processo administrativo para a apuração de infrações e a aplicação de penalidades no setor de transportes terrestres, por exemplo, é, anacronicamente, sigiloso e disfuncional em relação ao restante do ordenamento jurídico brasileiro, onde a regra é a publicidade dos processos administrativos. Com a adoção de maior transparência, a sociedade civil terá melhores condições de contribuir com o desempenho do setor, e de intervir para assegurar o respeito ao interesse público, que é o fim primeiro do Estado.

Outro exemplo da falha do governo está na falta de transparência e imprecisão em que trata a questão da extensão da malha ferroviária. Segundo a ANTT (2017), a extensão total da malha 
ferroviária é de, oficialmente, $29.075 \mathrm{~km}$, em 2017. No entanto, é sabido na que a rede em efetiva operação é, na prática, de pouco mais de $10 \mathrm{mil} \mathrm{km}$, como apontam auditorias do Tribunal de Contas da União (Felix e Cavalcante Filho, 2016). Segundo a auto declaração das concessionárias, em 2017, a rede em efetiva operação era de exatos $20.539,841 \mathrm{~km}$, como ilustrado na tabela 4.9 .

Tabela 4.9 Extensão líquida da malha ferroviária do Brasil em 2017 (em km)

\begin{tabular}{|c|c|c|c|c|c|}
\hline \multirow{2}{*}{ Ferrovias } & \multicolumn{5}{|c|}{ Bitolas (km) } \\
\hline & $(1,6 m)$ & (1m) & Mista & Inoperante & Líquido \\
\hline Rumo-ALL (MN) & 735,261 & & & & 735,261 \\
\hline Rumo-ALL (MO) & & 1973,118 & & 722,420 & $1.250,698$ \\
\hline Rumo-ALL (MP) & $1.544,012$ & & & 655,672 & 888,340 \\
\hline Rumo-ALL (MP) & & 242,071 & & 236,211 & 5,860 \\
\hline Rumo-ALL (MP) & & & 269,236 & 48,499 & 220,737 \\
\hline Rumo-ALL (MS) & & $7.223,370$ & & $2.223,233$ & $5.000,137$ \\
\hline Estrada de Ferro Paraná Oeste & & 248,098 & & & 248,098 \\
\hline Centro-Atlântica (FCA) & & $7.088,859$ & & 963,867 & $6.124,992$ \\
\hline Centro-Atlântica (FCA) & 2,630 & & & & 2,630 \\
\hline Centro-Atlântica (FCA) & & & 130,643 & 12,519 & 118,124 \\
\hline VLI-FNS-Norte & 744,500 & & & 127,900 & 616,600 \\
\hline VLI-FNS-Central & 855,798 & & & & 855,798 \\
\hline Ferrovia Tereza Cristina & & 163,447 & & & 163,447 \\
\hline Transnordestina (FTL) & & $4.275,137$ & & $3.059,997$ & $1.215,140$ \\
\hline Transnordestina (FTL) & & & 20,000 & 1,000 & 19,000 \\
\hline MRS & $1.612,567$ & & & 216,169 & $1.396,398$ \\
\hline MRS & & & 72,886 & 18,587 & 54,299 \\
\hline Vale EFC & 977,969 & & & & 977,969 \\
\hline Vale VM & & 872,684 & & 247,903 & 624,781 \\
\hline Vale VM & & & 21,532 & & 21,532 \\
\hline Total & $6.472,737$ & $22.086,784$ & 514,297 & $8.533,977$ & $20.539,841$ \\
\hline
\end{tabular}

Fonte: ANTT (2017)

Não obstante, na recentíssima publicação oficial do governo federal (Anuário Estatístico de Transportes 2010-2016) a extensão total da malha ferroviária é indicada como sendo de 30,6 mil km. Se a primeira vista o valor agregado parece convergir, quando são analisados os dados desagregados ${ }^{71}$, percebe-se que a publicação de Brasil (2017) é alicerçada, basicamente, no Plano Nacional de Viação de 1973 (PNV, 2017), com inúmeras inconsistências, como, por exemplo, as ausências das EF-151 (FNS) e EF-334 (FIOL), maiores obras do governo federal em execução no setor ferroviário.

Tais falhas de governo, em parte, explicam porque a qualidade da infraestrutura ferroviária, apesar de todos os avanços decorrentes das concessões, ainda é insuficiente no Brasil.

\footnotetext{
${ }^{71}$ Disponível em : https://www.transportes.gov.br/images/bit/Tabelas_Anu\%C3\%A1rio_Estat\%C3\%ADstico_de_Transportes/03_I nfraestrutura/02_Ferro/3.2.1.pdf Acessado em 21/06/2017.
} 


\section{O ESTUDO DE CASO}

O estudo de caso visa compreender o atual setor ferroviário brasileiro, à luz de duas investigações exploratórias paralelas. A primeira compara os benchmarks internacionais, selecionados por critérios qualidade e extensão, a fim de identificar padrões e características internacionais que possam explicar por que a qualidade da infraestrutura brasileira é insuficiente. A segunda investiga a adesão dos atores interessados a determinadas opções de exploração, possivelmente mais aptas ao desenvolvimento ferroviário brasileiro.

Em ambas investigações são usadas técnicas não paramétricas para análise dos dados. No levantamento dos atores é usado o conceito de NPR (Número de Prioridade de Risco), seguindo a lógica de Análise de Modo e Efeitos de Falhas (FMEA), a fim de mensurar a criticidade dos riscos apontados pelos atores interessados.

\subsection{BENCHMARKING INTERNACIONAL}

O benchmarking internacional, inicialmente focado nos benchmarks Reino Unido, Estados Unidos e China, identificou quatro possíveis fatores principais associados ao sucesso do empreendimento ferroviário: integração da indústria; existência de competição em rotas ou pela infraestrutura; regime de propriedade das firmas; e existência de unidade de bitolas.

A integração da indústria, refere-se ao modelo de exploração variando do integralmente vertical onde à firma explora toda a cadeia produtiva da atividade ferroviária, i.e. construção, exploração da infraestrutura, manutenção e segurança das linhas, operação dos trens, etc cujo benchmark principal é a China ao integralmente horizontal em que cada atividade da cadeia produtiva é segregada em uma firma diferente, cujo benchmark principal é o Reino Unido.

A existência de competição em rotas diz respeito a possibilidade de haver rotas alternativas entre os principais nós da malha. A antítese desse conceito é a agregação geográfica integral (monopólio de bacias), no qual ou não existem rotas alternativas ou as rotas alternativas existentes são dominadas pela mesma firma em regime de monopólio. Os Estados Unidos são o benchmark da competição em rotas. Além da competição por rotas, há também a competição pelo acesso a infraestrutura característica do open access, notadamente o modelo europeu.

O regime de propriedade da firma foi restrito as opções dicotômicas entre privados e públicos, em razão da dominância de um ou outro modelo entre as firmas componentes do mercado. Não se levou em consideração na análise se a titularidade da firma é ou não de domínio público, como no caso atual do Brasil e do Reino Unido em que a maioria das firmas são 
privadas, em regime de concessão temporária do Poder Público. Nesses casos, os países foram classificados em regime privado.

Por fim, o último fator analisado foi a unidade de bitola. A essa variável foi atribuído valor 1 (sim) nos casos em que pelo menos $95 \%$ da rede está unificada em uma bitola, independente de qual seja, e 0 (não) nos demais casos.

Os vinte países comparados, listados na tabela 5.1, foram selecionados segundo três critérios. Os dez de melhor qualidade da infraestrutura ferroviária, segundo o ranking de World Econominc Forum (2017). Os dez de maior extensão da malha, segundo o ranking da Central Inteligence Agency (2017). Além dos países selecionados por esses dois critérios, Reino Unido e Taiwan (China) foram introduzidos em razão de sua relevância histórica e pertinência com esta pesquisa, respectivamente. 
Tabela 5.1 Características ferroviárias básicas dos países comparados

\begin{tabular}{|c|c|c|c|c|c|c|c|c|c|c|}
\hline \multirow[b]{2}{*}{ País } & \multirow{2}{*}{$\begin{array}{c}\text { Índice } \\
\text { Qualidade }\end{array}$} & \multirow{2}{*}{$\begin{array}{c}\text { Extensão } \\
\quad(\mathbf{k m})\end{array}$} & \multirow{2}{*}{$\begin{array}{c}\text { Densidade } \\
1.000 \mathrm{~km} / \mathrm{km}^{2}\end{array}$} & \multicolumn{2}{|c|}{ Integração Horizontal } & \multirow[b]{2}{*}{ Integração Vertical } & \multicolumn{3}{|c|}{ Modelo Principal } & \multirow{2}{*}{$\begin{array}{c}\text { Unificação } \\
\text { Bitola }\end{array}$} \\
\hline & & & & Infraestrutura & Operação & & Competição & Propriedade & Mercado & \\
\hline Alemanha & 5,5 & 43.468 & 124,7 & $\begin{array}{l}\text { Deutsche Bahn } \\
\text { Netz AG }\end{array}$ & DB et al. ${ }^{72}$ & Deutsche Bahn & Infraestrutura & Púb. \& Priv. & Misto & $99 \%$ \\
\hline Argentina & 2,1 & 36.917 & 13,5 & $\begin{array}{l}\text { Trenes Argentinos } \\
\text { Infraestructura }\end{array}$ & $\begin{array}{c}\text { Operadora } \\
\text { Ferroviaria del } \\
\text { Estado }^{74} \\
\end{array}$ & $\begin{array}{c}\text { Ferrocarriles } \\
\text { Argentinos Sociedad } \\
\text { del Estado } \\
\end{array}$ & Monopólio & Pública & Misto & $71 \%$ \\
\hline Austrália ${ }^{76}$ & 4,1 & 36.968 & 4,8 & ARTC et al. & Aurizon et al. & Rio Tinto et al. & $\begin{array}{c}\text { Rotas \& } \\
\text { Infraestrutura }\end{array}$ & Púb. \& Priv. & Misto & $51 \%$ \\
\hline Brasil & 2,0 & 28.538 & 3,4 & - & - & $\begin{array}{l}\text { Rumo, Vale, VLI, } \\
\text { MRS, FTC }\end{array}$ & Monopólio & Privada & Cargas & $82 \%$ \\
\hline Canadá & 4,9 & 77.932 & 8,6 & - & - & $\begin{array}{c}\text { Canadian Rail, } \\
\text { Canadian Pacific e } \\
\text { Via Rail }\end{array}$ & Rotas & Púb. \& Priv. & Cargas & $100 \%$ \\
\hline China & 4,8 & 191.270 & 20,5 & - & - & $\begin{array}{c}\text { China Railway } \\
\text { Corporation }\end{array}$ & Monopólio & Pública & Misto & $99 \%$ \\
\hline Cingapura & 5,9 & 241 & 337,7 & - & - & $\begin{array}{c}\text { SMRT Corporation \& } \\
\text { SBS Transit }\end{array}$ & Monopólio & Pública & Pax & - \\
\hline $\begin{array}{l}\text { Coreia do } \\
\text { Sul }\end{array}$ & 5,7 & 3.460 & 35,7 & $\begin{array}{c}\text { Korea Rail } \\
\text { Network Authority }\end{array}$ & $\begin{array}{c}\text { Korea Railroad } \\
\text { Corporation } \\
\text { (Konrail) } \\
\end{array}$ & 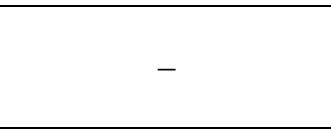 & Monopólio & Pública & Pax & $100 \%$ \\
\hline Espanha & 5,5 & 16.102 & 32,3 & $\begin{array}{c}\text { Administrador de } \\
\text { Infraestructuras } \\
\text { Ferroviarias } \\
(A D I F)\end{array}$ & $\begin{array}{c}\text { Renfe Operadora } \\
\text { et al. }\end{array}$ & - & Infraestrutura & Púb. \& Priv. & Pax & $74 \%$ \\
\hline $\begin{array}{l}\text { Estados } \\
\text { Unidos }\end{array}$ & 5,5 & 293.564 & 32,1 & $x_{1}$ & - & $\begin{array}{l}\text { BNSF Railway, } \\
\text { Amtrak et al. }\end{array}$ & Rotas & Púb. \& Priv. & Cargas & $100 \%$ \\
\hline
\end{tabular}

${ }^{72}$ DB - Deutsche Bahn domina 78\% do mercado de passageiros. O mercado de cargas é operado por: DB e autoridades locais, $14 \%$; estatais estrangeiras, $39 \%$; privadas alemãs $38 \%$ e privadas estrangeiras $9 \%$, respectivamente (Bundesnetzagentur (2016).

${ }^{73} \mathrm{https}: / /$ www.argentina.gob.ar/adifse

$74 \mathrm{http} / / /$ servicios.infoleg.gob.ar/infolegInternet/anexos/135000-139999/138931/norma.htm

$75 \mathrm{http}: / /$ mepriv.mecon.gov.ar/Normas $2 / 27132 . \mathrm{htm}$

${ }_{76} \mathrm{O}$ mercado australiano aplica ambos os modelos de integração (Merkert \& Henser, 2014). 


\begin{tabular}{|c|c|c|c|c|c|c|c|c|c|c|}
\hline Finlândia 77 & 5,6 & 5.919 & 19,5 & $\begin{array}{c}\text { Finish Transport } \\
\text { Agency }\end{array}$ & VR Group & - & Monopólio & Pública & Pax & $100 \%$ \\
\hline França & 5,8 & 29.640 & 46,3 & $\begin{array}{l}\text { Société nationale } \\
\text { des chemins de fer } \\
\text { français }(S N C F)\end{array}$ & Thalys et al. & $S N C F$ & Infraestrutura & Púb. \& Priv. & $\operatorname{Pax}$ & $99 \%$ \\
\hline Holanda & 5,8 & 3.223 & 95,1 & $\begin{array}{l}\text { Railinfratrust } \\
\text { Company }\end{array}$ & $\begin{array}{c}\text { Nederlandse } \\
\text { Spoorwegen (NS) } \\
\text { et al. }\end{array}$ & - & Infraestrutura & Pública & $\operatorname{Pax}$ & $100 \%$ \\
\hline Hong Kong & 6,3 & 210 & 191,0 & - & 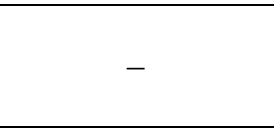 & $\begin{array}{c}\text { Mass Transit Railway } \\
\text { Corporation Limited } \\
(M T R)\end{array}$ & Monopólio & Púb. \& Priv. & $\operatorname{Pax}$ & - \\
\hline Índia & 4,4 & 68.525 & 23,1 & - & - & Indian Railways (IR) & Monopólio & Pública & Misto & $85 \%$ \\
\hline Japão & 6,2 & 27.311 & 74,9 & $\begin{array}{c}\text { Central Japan } \\
\text { Railway Company } \\
\text { et al. }\end{array}$ & $\begin{array}{c}\text { Japan Freight } \\
\text { Railway Company } \\
\text { et al. }\end{array}$ & $\begin{array}{c}\text { Central Japan } \\
\text { Railway Company et } \\
\text { al. }\end{array}$ & Rotas & Púb. \& Priv. & Pax & $80 \%$ \\
\hline $\begin{array}{l}\text { Reino } \\
\text { Unido }\end{array}$ & 4,7 & 16.837 & 69,6 & Network Rail & Eurostar et al. & 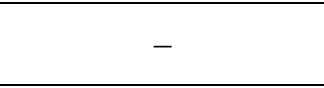 & Monopólio $^{78}$ & Púb. \& Priv. & Pax & $98 \%$ \\
\hline Rússia & 4,5 & 87.157 & 5,3 & - & - & $\begin{array}{c}\text { Ferrovias Russas } \\
(R Z D) \text { et al. }\end{array}$ & Monopólio & Pública & Cargas & $99 \%$ \\
\hline Suíça & 6,6 & 5.652 & 141,3 & $\begin{array}{c}\text { Swiss Federal } \\
\text { Railways (SBB } \\
\text { CFF FFS }) \\
\end{array}$ & BLS et al. & & Monopólio & Pública & Pax & $80 \%$ \\
\hline Taiwan & 5,3 & 1.597 & 49,5 & 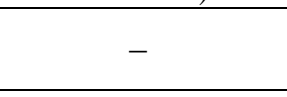 & - & $\begin{array}{l}\text { Taiwan Railway } \\
\text { Administration }\end{array}$ & Monopólio & Pública & $\operatorname{Pax}$ & $69 \%$ \\
\hline
\end{tabular}

${ }^{77}$ Mäkitalo (2011);

${ }^{78}$ Shaw et al. (1998); 


\subsection{LEVANTAMENTO DOS ATORES}

A pesquisa do estudo de caso visa avaliar a percepção dos atores interessados do mercado ferroviário quanto à qualidade do modo ferroviário brasileiro em geral, a gradação de importância dos entraves identificados para o Brasil, e testar a hipótese de que cada ferrovia pode ou não ser explorada por um modelo específico.

A pesquisa foi distribuída por e-mail aos atores interessados vinculados à academia e aos principais órgãos e entidades do setor ferroviário, como ANTF, ANTT, ANUT, DNIT, EPL, SPPI e VALEC.

Os programas de Pós-graduação em Transportes das Universidades de Brasília e Santa Catarina ajudaram na divulgação do estudo aos seus corpos docentes e discentes, em seus sites oficiais na internet. O levantamento também foi distribuído a professores da PósGraduação em Transportes do IME, UFCE e USP. O questionário também foi distribuído a outros profissionais de áreas afins ao tema, como Consultores Legislativos em Transportes da Câmara dos Deputados e do Senado Federal, Auditores da CGU e TCU, Peritos da Polícia Federal e pesquisadores do IPEA.

Para retratar o interesse do Mercado, o levantamento foi distribuído para representantes da MRS Logística, Rumo-ALL, ANTF, ANPTrilhos e ANUT. O levantamento também foi divulgado em fóruns especializados em discussões sobre o transporte ferroviário de passageiros e cargas nas redes sociais da internet.

Os resultados obtidos apresentaram algumas características que restringem, por rigor metodológico, o alcance das conclusões da pesquisa. Assim, os resultados devem ser entendidos como um estudo de caso que pode servir de base para futuras pesquisas com maior amplitude e aleatoriedade na coleta dos dados. Dentre essas características pode-se descrever que parte significativa dos pesquisados foram contatados diretamente pelo pesquisador, e, portanto, não esgotam o rol de stakeholders do mercado ferroviário no Brasil. Foram coletadas ao todo sessenta e nove respostas válidas, quantidade considerada convergente com a pesquisa de Resende et al. (2009), que obteve quarenta respostas válidas.

Foram arquivados 70 registros referentes a 121 variáveis respondidas diretamente pelos atores interessados entrevistados, sendo que apenas 1 registro foi descartado por ser idêntico ${ }^{79}$ a uma resposta anterior em um intervalo de 9 minutos, assim, foi considerado erro de coleta. Não houve nenhuma outra resposta idêntica na amostragem.

\footnotetext{
${ }^{79}$ A resposta registrada às 17:51 de $1^{\circ}$ de agosto de 2017 foi excluída por ser idêntica a resposta imediatamente anterior registrada às $16: 42$.
} 


\subsubsection{Instrumento de Pesquisa}

Para tanto, foi proposto o questionário do Apêndice A, cujo levantamento foi aplicado entre 19 de junho de 2016 e 3 de outubro de 2016, conforme ilustrado na figura 5.1.

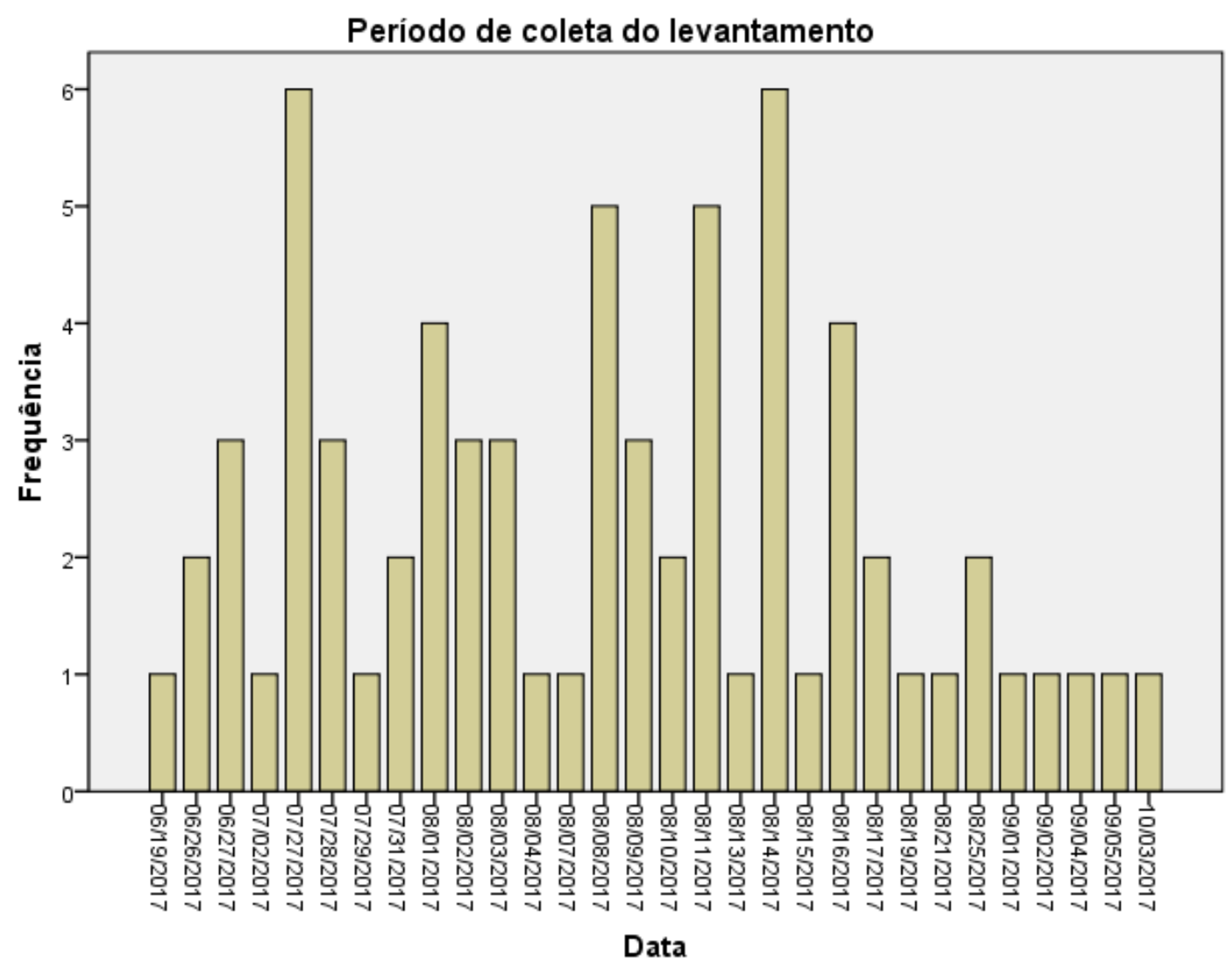

Figura 5.1 Período de registro dos dados do levantamento entre os atores interessados

\subsubsection{Perfil dos Respondentes}

A primeira parte do questionário procura identificar o perfil do respondente. Qual sua identificação com os atores interessados (Academia, Concessionário, Fiscalização, Governo, Legisladores, Reguladores, Operadores e Usuários). Espera-se efetuar cotejos entre esses perfis de respondentes. Além disso se investiga o tipo de formação e o tempo de experiência no setor.

A questão 1 tinha como objetivo identificar o grau de convergência das respostas dos diversos atores. A estratificação procurou ser o mais analítico possível ao segregar grupos que embora ajam por interesse público ou privado, possam, eventualmente, ter interesses divergentes, como, por exemplo, o IBAMA, que embora seja um órgão do governo, para o setor ferroviário age como um agente limitador. A VALEC embora legalmente seja entidade da administração - uma concessionária ferroviária - age na prática como um órgão do governo 
sem autonomia ou independência. Os concessionários e usuários podem divergir quanto aos preços das tarifas, por exemplo, em que pesem agirem por interesse privados.

\subsubsection{Avaliação Geral}

A segunda parte do questionário procura capturar a avaliação geral dos respondentes, quanto a extensão da malha, qualidade da infraestrutura e da oferta, a quantidade da demanda, a rentabilidade da demanda, o valor dos fretes, a intensidade da concorrência intra e intermodal, o grau de participação privada e pública, e, por fim, o grau de intervenção regulatória.

\subsubsection{Avaliação dos Riscos}

A terceira parte do questionário busca identificar a percepção dos respondentes quanto a importância dos principais entraves identificados, tanto para o transporte de cargas quanto o de passageiros. Espera-se observar discrepâncias nas respostas em razão das maiores dificuldades do transporte de passageiros em relação ao de cargas, notadamente quanto ao financiamento e a regulação.

\subsubsection{Avaliação dos Modelos}

Nessa parte ainda serão avaliados 10 ramais ferroviários, existentes ou projetados, quanto aos modelos de organização da exploração, participação pública ou privada, critérios para seleção de vencedores em leilões, bitolas, utilidade, viabilidade econômica, e prioridade.

Quanto a titularidade no setor ferroviário brasileiro, as alternativas de respostas eram: “integralmente privado", “concessão”, "integralmente público" e "não sei ou não se aplica”.

Buscava-se avaliar a possibilidade de adesão dos atores interessados brasileiros à adoção do modelo americano, integralmente privado de titularidade das ferrovias, em contraponto ao próprio modelo brasileiro que, embora permita a exploração integralmente pública, a exemplo das ferrovias outorgadas à estatal Valec, adota, na prática, a concessão como paradigma de titularidade.

Quanto a exploração do compartilhamento da malha ferroviária brasileira, as alternativas de respostas eram: "integração vertical com exclusividade", "vertical com permissão de tráfego mútuo", "vertical com permissão de direito de passagem", "open access" e "não sei ou não se aplica”. Buscava-se avaliar a adesão dos atores interessados brasileiros à adoção do modelo de integração vertical com compartilhamento da malha (direito de passagem e tráfeguo mútuo) versus os demais modelos já em uso no Brasil. 
Quanto ao critério de adjudicação dos vencedores de leilões ferroviários, em caso de hipotéticas licitações das ferrovias levantadas, os entrevistados foram convidados a apontar o critério de outorga mais adequado para as ferrovias brasileiras, onde as alternativas de respostas eram: "menor valor de tarifa", "menor valor de contraprestação pública", "maior valor de outorga privada", "menor tempo de exploração", "maior capacidade de movimentação de carga" e "não sei ou não se aplica". Notar que os critérios apresentados na pesquisa não são exatamente os mesmos da Lei $\mathrm{n}^{\circ}$ 8.987, de 1995, Medida Provisória $\mathrm{n}^{\circ}$ 2.217-3, de 2001 ou Lei n ${ }^{\circ} 11.079$, de 2014. Buscava-se avaliar a adesão dos atores interessados brasileiros à adoção dos critérios de "menor tempo de exploração" inexistente na legislação ferroviária e "maior capacidade de movimentação de carga", existente explicitamente apenas na legislação portuária, Lei $\mathrm{n}^{\circ}$ 12.815, de 2013.

Quanto as bitolas, os entrevistados foram convidados a apontar a bitola mais apropriada para as ferrovias brasileiras, onde as alternativas de respostas eram: "larga 1600mm", "standard 1435mm", "estreita 1000mm", "mista (larga e estreita)" e "não sei ou não se aplica". Buscava-se avaliar a percepção dos atores interessados brasileiros quanto ao conflito causado pela diversificação de bitolas na rede ferroviária do Brasil, que não aplicou a unificação de bitolas como fizeram China, Estados Unidos, Canadá, México etc.

Os entrevistados foram convidados a apontar, por meio de uma escala de Likert, onde as alternativas de respostas eram: "pouquíssimo útil”, "pouco útil”, "útil”, "muito útil” e "muitíssimo útil", a utilidade declarada. Buscava-se avaliar o nível de satisfação decorrentes das ferrovias existentes e planejadas, a fim de verificar se (i) os pesquisados percebem as ferrovias com o mesmo nível de utilidade e (ii) caso exista diferença significativa se o nível de utilidade percebido pelos atores interessados é o mesmo manifesto pelas escolhas do governo federal.

Os entrevistados também foram convidados a apontar a viabilidade econômica das ferrovias do estudo por meio de uma escala de Likert, onde as alternativas de respostas eram: “pouquíssimo viável”, “pouco viável”, "viável”, "muito viável” e “muitíssimo viável”. Buscava-se avaliar o nível percebido de viabilidade econômica das ferrovias existentes e planejadas, a fim de verificar se (i) os pesquisados percebem as ferrovias com o mesmo nível de viabilidade e (ii) caso exista diferença significativa se o nível de viabilidade percebido pelos atores interessados é o mesmo manifesto pelas escolhas do governo federal.

Por fim, os entrevistados foram convidados a apontar o grau de prioridade das ferrovias do estudo por meio de uma escala de Likert, onde as alternativas de respostas eram: "urgentíssimo", "urgente”, "normal”, "baixo” e "muito baixo. Buscava-se avaliar a percepção 
dos atores interessados quanto ao grau percebido de prioridade das ferrovias existentes e planejadas, a fim de verificar se (i) os pesquisados percebem as ferrovias com o mesmo grau de prioridade e (ii) caso exista diferença significativa se o grau de grau percebido pelos atores interessados é o mesmo manifesto pelas escolhas do governo federal.

\subsubsection{Avaliação das ferrovias}

Procurou-se selecionar para o estudo ferrovias tanto de cargas quanto de passageiros, existentes ou planejadas, em razão de critérios de importância e recorrência no planejamento estatal, como ilustrado na tabela 5.2.

Tabela 5.2 Ferrovias selecionadas para a pesquisa juntos aos atores interessados

\begin{tabular}{ll}
\hline Ferrovias & Justificativa \\
\hline EF-170 - Ferrogrão & Hipoteticamente, essa ferrovia seria ideal para exploração integralmente privada, em \\
& razão de sua viabilidade econômica. A ferrovia é iniciativa de investidores privados \\
& (Bunge, Cargil, Maggi e Louis Dreyfus) ligados ao agronegócio do Centro-Oeste \\
& (Turtelli, 2017). Essa concessão estava prevista no PIL 2 e no projeto Crescer.
\end{tabular}

EF-151 - Ferrovia Essa ferrovia tem função estratégica para unificação da rede em bitola larga e para Norte Sul (FNS) desenvolvimento econômico do centro-oeste do país. Essa concessão estava prevista no PIL 2 e no projeto Crescer.

EF-334 - Ferrovia de Integração OesteLeste (FIOL)

EF-354 - Ferrovia de Integração CentroOeste (FICO)

Nova Transnordestina

Ferroanel de São Paulo

Ferrovia Transpequi (Brasília - Goiânia)

Ferrovia Intercidades (SP)
Hipoteticamente, essa ferrovia tem sua viabilidade econômica questionada, pode ser um indicador de priorização política do Estado. Essa concessão estava prevista no projeto Crescer.

Hipoteticamente, essa ferrovia tem importância estratégica para consolidação dos portos do arco norte e integração da malha em bitola larga rumo ao oeste.

Com $1.753 \mathrm{~km}$ de extensão em linha principal, a ferrovia passa por 81 municípios, partindo de Eliseu Martins, no Piauí, em direção aos portos do Pecém, no Ceará, e Suape, em Pernambuco (CSN, 2017). Hipoteticamente, essa ferrovia tem sua viabilidade questionada, pode ser um indicador de priorização política do Estado. Essa concessão não estava prevista no projeto Crescer nem no PIL.

É considerado o maior gargalo ferroviário do Brasil. Há quase duas décadas os governos federal e estadual tentam encontrar uma solução para transpor a cidade de São Paulo sem atrapalhar o transporte de passageiro (Otta, 2017). Constou entre os projetos do PIL. Aumentaria a eficiência no acesso ao porto de Santos e no tráfego entre São Paulo e Rio de Janeiro.

Projeto greenfield de transporte de passageiros. Pelo estudo original da ANTT, o trem teria um percurso de 207 quilômetros, e rodaria a uma velocidade média de $160 \mathrm{~km} / \mathrm{h}$, com a passagem estimada em $\mathrm{R} \$ 60$, preço similar à viagem de ônibus expresso. (Pelegi, 2017)

Segundo Costa (2017), o Trem Intercidades (TIC), entre Campinas, São Paulo, Vale do Paraíba e Baixada Santista, com $431 \mathrm{~km}$ de extensão, terá velocidade média de $120 \mathrm{~km} / \mathrm{h}$, ao custo de $\mathrm{R} \$ 20$ bilhões e demanda de $60 \mathrm{mil} \mathrm{pax} / \mathrm{dia}$. O projeto aproveitaria a faixa de domínios das ferrovias de carga e da Companhias de Trens Metropolitanos (CPTM). A primeira etapa do projeto, orçada em R $\$ 5$ bilhões ligaria Americana e São Paulo, em uma extensão de $135 \mathrm{~km}$. Essa ferrovia de passageiros seria formado por uma parceria entre os governos estadual e federal e a iniciativa 


\begin{tabular}{|c|c|}
\hline Ferrovias & Justificativa \\
\hline & privada. \\
\hline $\begin{array}{l}\text { Rumo-ALL (Malha } \\
\text { Paulista) }\end{array}$ & Ferrovia em estudo para prorrogação antecipada (Scaramuzzo \& Pereira, 2016). \\
\hline $\begin{array}{l}\text { MRS (Santos - Belo } \\
\text { Horizonte) }\end{array}$ & Ferrovia em estudo para prorrogação antecipada (Otta \& Borges, 2017). \\
\hline
\end{tabular}

\subsection{FAILURE MODE AND EFFECTS ANALYSIS (FMEA)}

Segundo Pardo (2009), por meio da Análise de Modo e Efeitos de Falhas (FMEA) é possível organizar e classificar os riscos de forma a identificar a relevância de cada um deles. Os riscos estudados neste levantamento, identificados com a colaboração de especialistas, foram: risco de insegurança jurídica, risco de baixa demanda, risco de baixa rentabilidade, risco de não financiamento, risco de não licenciamento ambiental e risco de elevação dos custos de implantação.

Segundo Fogliatto (2003), a FMEA consiste na determinação da priorização da prevenção de uma falha, por meio de três componentes: ocorrência $(\mathrm{O})$, severidade $(\mathrm{S})$ e detecção $(\mathrm{D})$. Moura (2000) define a ocorrência como a probabilidade de uma falha vir a ocorrer. A ocorrência deve ser classificada de 1 a 10 pela frequência com que uma falha pode ocorrer. Neste estudo, os respondentes foram convidados a avaliar os riscos em uma escala de Likert, em que as possibilidades de respostas eram: "Muitíssimo improvável, quase nunca ocorre", "Pouco provável, às vezes ocorre", "Provável ocorrer em metade do tempo", "Muito provável, ocorre com frequência" e "Muitíssimo provável, quase sempre ocorre". Seguindo a sugestão de Moura (2000) as respostas foram então convertidas em números segundo a seguinte tabela 5.3:

Tabela 5.3 Critério de avaliação de Ocorrência adaptado

\begin{tabular}{|c|c|c|c|}
\hline Opção de resposta & Probabilidade de falha & Índice de Ocorrência & Valor atribuído \\
\hline $\begin{array}{l}\text { Muitíssimo provável, } \\
\text { quase sempre ocorre }\end{array}$ & $\begin{array}{l}\text { Muito alta: falha quase } \\
\text { inevitável }\end{array}$ & 10 a 9 & 9,5 \\
\hline $\begin{array}{l}\text { Muito provável, ocorre } \\
\text { com frequência }\end{array}$ & Alta: falhas frequentes & 8 a 7 & 7,5 \\
\hline $\begin{array}{l}\text { Provável ocorrer em } \\
\text { metade do tempo }\end{array}$ & $\begin{array}{l}\text { Moderada: Falhas } \\
\text { ocasionais }\end{array}$ & 6 a 5 & 5,5 \\
\hline $\begin{array}{l}\text { Pouco provável, às vezes } \\
\text { ocorre }\end{array}$ & Baixa: Poucas falhas & 4 a 3 & 3,5 \\
\hline $\begin{array}{c}\text { Muitíssimo improvável, } \\
\text { quase nunca ocorre }\end{array}$ & $\begin{array}{l}\text { Remota: Falha é } \\
\text { improvável }\end{array}$ & 2 a 1 & 1,5 \\
\hline
\end{tabular}


Moura (2000) define a severidade como a gravidade do efeito do modo de falha. A severidade deve ser classificada de 1 a 10 em função do efeito que uma falha pode provocar. Neste estudo, os respondentes foram convidados a avaliar efeitos dos riscos em uma escala de Likert, em que as possibilidades de respostas eram: "Pouquíssimo importante", "Pouco importante", "Média importância", "Muito importante" e "Muitíssimo importante". Seguindo a sugestão de Moura (2000) as respostas foram então convertidas em números segundo a seguinte tabela 5.4:

Tabela 5.4 Critério de avaliação de Severidade adaptado

\begin{tabular}{|c|c|c|c|}
\hline Opção de resposta & Efeito & Índice de Severidade & Valor atribuído \\
\hline Muitíssimo importante & $\begin{array}{l}\text { Perigoso, sem ou com } \\
\text { aviso prévio }\end{array}$ & 10 a 9 & 9,5 \\
\hline Muito importante & Muito alto ou alto & 8 a 7 & 7,5 \\
\hline Média importância & Moderado ou baixo & 6 a 5 & 5,5 \\
\hline Pouco importante & Muito baixo, menor & 4 a 3 & 3,5 \\
\hline Pouquíssimo importante & Muito menor, nenhum & 2 a 1 & 1,5 \\
\hline
\end{tabular}

Fonte: adaptado de Moura (2000)

Moura (2000) define a detecção como a capacidade dos mecanismos de controles de identificarem os modos de falhas antes que a falha ocorra. A detecção deve ser classificada de 1 a 10 em função da capacidade de detecção de uma falha. Neste estudo, os respondentes foram convidados a avaliar a possibilidade de detecção dos riscos em uma escala de Likert, em que as respostas eram: "Quase sempre detectável”, "Grandes chances de detecção", "Média chance de detecção", "Chance muito baixa de detecção" e "Quase nunca detectável". Seguindo a sugestão de Moura (2000) as respostas foram então convertidas em números segundo a seguinte tabela 5.5:

Tabela 5.5 Critério de avaliação de Detecção adaptado

\begin{tabular}{|c|c|c|c|}
\hline Opção de resposta & Detecção & Índice de Detecção & Valor atribuído \\
\hline Quase nunca detectável & $\begin{array}{l}\text { Absoluta incerteza, muito } \\
\text { remota }\end{array}$ & 10 a 9 & 9,5 \\
\hline $\begin{array}{c}\text { Chance muito baixa de } \\
\text { detecção }\end{array}$ & Remota ou muito baixa & 8 a 7 & 7,5 \\
\hline Média chance de detecção & Baixa ou moderada & 6 a 5 & 5,5 \\
\hline $\begin{array}{c}\text { Grandes chances de } \\
\text { detecção }\end{array}$ & $\begin{array}{l}\text { Moderadamente alta ou } \\
\text { alta }\end{array}$ & 4 a 3 & 3,5 \\
\hline Quase sempre detectável & $\begin{array}{c}\text { Muito alta ou quase } \\
\text { certamente }\end{array}$ & 2 a 1 & 1,5 \\
\hline
\end{tabular}

Fonte: adaptado de Moura (2000) 
Com base nas três componentes (ocorrência, severidade e detecção), a criticidade do risco pode ser calculada por meio do Número de Prioridade de Risco (Risk Priority Number):

$$
\mathrm{NPR}=\mathrm{O} \times \mathrm{S} \times \mathrm{D}
$$

Em razão da simplificação aplicada nesta pesquisa o NPR deste estudo varia entre 3,75 e 857,38 e não entre 1 e 1000, como na modelagem FMEA original de Chrysler Corporation et al. (1993).

\subsection{TÉCNICAS NÃO PARAMÉTRICAS}

\subsubsection{Teste $X^{2}$}

Segundo Callegari-Jacques (2003), a estatística $X^{2}$ foi criada por Karl Pearson, em 1899, para medir o grau de discrepância entre um conjunto de frequências observadas $(\mathrm{O})$ e o conjunto de frequências esperadas segundo determinada hipótese $(H)$, em que a estatística $X^{2}$ obedece a seguinte fórmula:

$$
X_{\text {calc }}^{2}=\sum \frac{(O-E)^{2}}{E}
$$

Para maiores informações sobre o teste $X^{2}$ de heterogeneidade de Karl Pearson, consultar Sweeney et al., 2013.

\subsubsection{Teste de Kruskall-Wallis}

Segundo Callegari-Jacques (2003), quando são violadas, de forma importante, as pressuposições de normalidade e homocedasticidade não se pode confiar no resultado de uma análise de variância (ANOVA) tradicional, pois a probabilidade de se cometer o erro do tipo I afasta-se marcadamente de $\alpha$. A alternativa não paramétrica para a ANOVA a um critério de classificação é o teste de Kruskal-Wallis.

A estatística do teste é dada pela fórmula:

$$
H=\frac{12}{N(N+1)} \sum \frac{R_{i}^{2}}{n_{i}}-3(N+1)
$$

Onde $\mathrm{n}_{\mathrm{i}}=$ tamanho de cada amostra, $\mathrm{N}=\sum \mathrm{n}_{\mathrm{i}}=$ número total de indivíduos e $\mathrm{R}_{\mathrm{i}}=$ soma dos postos em cada amostra. 


\subsubsection{Teste de Friedman}

$\mathrm{O}$ teste de Friedman é um teste não-paramétrico destinado a inferir se existe efeito de múltiplos $k$ tratamentos em relação ao efeito de múltiplos $b$ blocos (Pontes, 2000). O teste de Friedman é o equivalente não paramétrico para a ANOVA a dois critérios de classificação Callegari-Jacques (2003). No caso desta pesquisa, procura-se avaliar se existe diferença estatística entre os seis riscos levantados em relação a percepção dos $\mathrm{n}$ atores interessados entrevistados. Isto é, se os riscos atribuídos ao transporte de cargas e passageiros possuem as mesmas características na percepção dos entrevistados. Investiga-se, também, com base no teste de Friedman se as características atribuídas às ferrovias do estudo são estatisticamente convergentes em relação a opinião dos atores interessados.

Segundo Pontes (2000), a estatística S de Friedman é dada pela soma das diferenças quadráticas entre as médias dos postos dos tratamentos $\left(\mathrm{R}_{\mathrm{i}}, \mathrm{i}=1,2,3, \ldots, \mathrm{k}\right)$ por meio da seguinte fórmula:

$$
S=\frac{12}{b k(k+1)} \sum_{i=1}^{k} R_{i}^{2}-3 b(k+1)
$$

Onde:

$\mathrm{b}=$ número de blocos,

$\mathrm{k}=$ número de tratamentos,

$\mathrm{R}=$ somatório dos postos (ranks) em cada tratamento.

Quando há empates nos postos dentro do mesmo bloco, a estatística S de Friedman precisa ser corrigida dividindo-a pelo seguinte fator de correção:

$$
C=1-\frac{1}{b k\left(k^{2}-1\right)} \sum_{j=1}^{b} \sum_{l=1}^{e j}\left(d_{l j}^{3}-d_{l j}\right)
$$

Onde:

$e_{j}$ é o número de grupos empatados no bloco $\mathrm{j}$,

$d_{l j}$ é o número de observações empatadas no grupo 1 do bloco j.

Segundo Pontes (2000), para $n k \geq 30$ a estatística $S$ de Friedman pode ser comparada com uma distribuição $X^{2} \operatorname{com} k-1$ graus de liberdade.

No teste de Friedman, assim como nos demais testes não paramétricos, só há necessidade de realizar comparações múltiplas quando a hipótese nula é rejeitada, pois, tem-se que, ao menos um dos tratamentos é diferente dos demais. Neste sentido, o procedimento de comparações múltiplas permite determinar quais tratamentos são diferentes. As diferenças entre os 
tratamentos i e j é calculada a partir da diferença entre os ranks acumulados por meio da comparação com a diferença crítica $(\Delta)$, nos termos da seguinte desigualdade:

$$
|R i-R j| \geq \Delta
$$

Onde: ${ }^{80}$

$$
\Delta=Z_{\left(\frac{\alpha}{k(k-1)}\right)} \cdot \sqrt{\frac{N k(k+1)}{6}}
$$

O $\Delta$ da equação 5.7 é, portanto, uma função de $N$ blocos, $k$ tratamentos e significância $\alpha$ de uma distribuição normal ajustada, para se evitar o erro do tipo I, dividindo-se $\alpha$ por $\mathrm{k}(\mathrm{k}-1)$. Obviamente, não é necessário efetuar a combinação de k tratamentos dois a dois, basta que os ranks sejam ordenados das maiores diferenças para as menores e comparados ao $\Delta$ crítico da inequação 6.3. Se a diferença entre o somatório de ranks por tratamentos for maior que a diferença crítica, efetua-se nova comparação até que a diferença entre tratamentos seja menor que a diferença crítica.

${ }^{80}$ Field (2009) apresenta a inequação 6.3 colocando N no denominador. Todavia, o resultado dessa inequação levaria ao absurdo de se declarar tratamentos diferentes quando a hipótese zero não é rejeitada. 


\section{ANÁLISE DOS RESULTADOS}

O subitem 6.1 expõe as associações encontradas na comparação dos principais benchmarks em termos de qualidade, extensão e densidade da infraestrutura ferroviária, por meio de testes não paramétricos. O subitem 6.2 apresenta o resultado do levantamento da percepção dos atores interessados na forma de estatísticas descritivas do perfil dos atores e da avaliação geral do setor ferroviário. O subitem 6.3 apresenta a análise de criticidade dos riscos, baseado em FMEA. O subitem 6.4 apresenta a avaliação das 10 ferrovias amostradas, por meio de estatísticas não paramétricas ${ }^{81}$. Por fim, o subitem 6.5 apresenta as evidências extraídas do histórico ferroviário do Reino Unido, Estados Unidos, China e Brasil, por meio de uma análise empírica.

\subsection{EXPLORAÇÃO DA INFRAESTRUTURA FERROVIÁRIA}

O modelo de exploração ferroviária mais eficaz para proteger os clientes dos abusos das firmas monopolistas depende dos fatos do setor e da situação em particular de cada contexto (Pittman, 2011). Assim, neste subitem, procura-se demonstrar que os benchmarks ferroviários em termos de qualidade, extensão e densidade possuem características próprias que os direcionam para este ou aquele modelo. O fato do modelo de segregação horizontal ou institucional supostamente servir à Europa, pode não ter nenhuma relevância para o Brasil, em face das extremas diferenças entre o Brasil, e os países europeus.

Assim, os países analisados foram comparados quanto as características de integração, competição, propriedade, transporte e unificação de bitolas, consideradas juntas como variáveis preditoras no experimento. A hipótese nula é que não há diferença entre as características, enquanto a hipótese alternativa é que há diferença em alguma das características. Foi aplicado o teste não paramétrico de Kruskal-Wallis.

No subitem 6.1.1 são apresentados os resultados, quando a variável dependente é a qualidade da infraestrutura no conjunto dos dez países de melhor qualidade da infraestrutura ferroviária, segundo WEF (2017). No subitem 6.1.2 são apresentados os resultados, quando a variável dependente é a extensão da infraestrutura no conjunto dos dez países de maior extensão da infraestrutura ferroviária, segundo CIA (2017). No subitem 6.1.3 são apresentados os resultados, quando a variável dependente é a densidade da infraestrutura no conjunto dos dez

\footnotetext{
${ }^{81}$ Para aplicação do questionário, utilizou-se o ambiente Google Driver (Formulário Google Docs), disponível na nuvem. Para processamento e análise dos dados foram utilizados os softwares Microsoft Excel, versão 2013, e "Statistical Package for the Social Sciences" (SPSS), versão PASW Statistics 18, fabricado pela International Business Machines (IBM).
} 
países de maior densidade da infraestrutura ferroviária, segundo dados de CIA (2017) e WEF (2017).

\subsubsection{Características Associadas à Qualidade}

$\mathrm{Na}$ tabela 6.1, são observados os países analisados, ordenados pelo índice de qualidade da infraestrutura ferroviária presentes no relatório de competitividade global de WEF (2017). Na coluna Posição, têm-se a colocação do país na amostra (A) deste estudo - utilizada no teste de Kruskal-Wallis - e a colocação do país na população (P), no ranking de WEF (2017), com 137 países. Na coluna seguinte, têm-se o modelo de integração das atividades de exploração das infraestruturas ferroviárias e das operações dos trens, imposto pela regulação de cada país. Monopólio, na coluna Competição, representa a inexistência disputa por passageiros ou cargas, seja porque todas as empresas envolvidas são públicas, como, por exemplo, na Finlândia e Suíça, seja porque, apesar de haver diferenças entre a propriedade das firmas, as reformas regulatórias, postas em prática, não resultaram em competição, como, por exemplo, no Reino Unido ${ }^{82}$ e também Finlândia ${ }^{83}$. Monopólio também foi assinalado em casos como o do Brasil, em que apesar de haver firmas privadas atuando no mercado, a distribuição geográfica da malha e os processos de fusões das concessionárias resultaram em falta de competição intramodal. Quando existe competição, rotas é classificação associada a integração vertical, em que mais de uma ferrovia independente compete por cargas e passageiros entre as mesmas origens e/ou destinos. Infraestrutura foi a classificação associada as ferrovias em que mais de uma operadora diferente compete pelo acesso a mesma infraestrutura.

A coluna Propriedade indica se as firmas atuantes no mercado são públicas e privadas, ou apenas públicas ou apenas privadas. Mercado indica a dominância do uso da malha entre o transporte de cargas ou de passageiros. Segundo dados de IGR-Rail (2017) entre todos os países europeus amostrados, apenas a Alemanha emprega a rede no transporte ferroviário em repartição equilibrada em carga e passageiros. Nos demais países europeus, a repartição do transporte de cargas é secundaria em relação ao de passageiros. Por fim, a coluna UB (\%), Unificação da Bitola, representa a percentagem da extensão das linhas na bitola dominante em relação a malha total em cada ${ }^{84}$ país, independente de qual é a dimensão da bitola dominante. A Rússia, por exemplo, adota a bitola de 1,520mm em 99\% de sua malha, já a França adota o espaçamento de 1,435mm em $99 \%$ de sua malha ferroviária.

\footnotetext{
${ }^{82}$ Jupe (2009), Jupe \& Crompton (2006), e Bowman (2015).

${ }^{83}$ Mäkitalo (2011).

${ }^{84}$ Os valores de Cingapura e Hong Kong foram estimados pela média da amostra.
} 
Tabela 6.1 Países amostrados por qualidade da infraestrutura

\begin{tabular}{|c|c|c|c|c|c|c|c|c|}
\hline \multirow{2}{*}{ País } & \multirow{2}{*}{$\begin{array}{c}\text { Índice } \\
\text { Qualidade }\end{array}$} & \multicolumn{2}{|c|}{ Posição } & \multirow{2}{*}{ Integração } & \multirow{2}{*}{ Competição } & \multirow{2}{*}{ Propriedade } & \multirow{2}{*}{ Mercado } & \multirow{2}{*}{$\mathbf{U B}(\%)$} \\
\hline & & $\mathrm{A}$ & $\mathrm{P}$ & & & & & \\
\hline Suíça & 6,6 & 1 & 1 & Horizontal & Monopólio & Pública & $\operatorname{Pax}$ & 80 \\
\hline Hong Kong & 6,3 & 2 & 2 & Vertical & Monopólio & Púb. \& Priv. & $\operatorname{Pax}$ & 88 \\
\hline Japão & 6,2 & 3 & 3 & Vertical & Rotas & Púb. \& Priv. & $\operatorname{Pax}$ & 80 \\
\hline Cingapura & 5,9 & 4 & 4 & Vertical & Monopólio & Pública & $\operatorname{Pax}$ & 88 \\
\hline França & 5,8 & 5 & 5 & Horizontal & Infraestrutura & Púb. \& Priv. & $\operatorname{Pax}$ & 99 \\
\hline Holanda & 5,8 & 6 & 6 & Horizontal & Infraestrutura & Pública & $\operatorname{Pax}$ & 100 \\
\hline Coreia do Sul & 5,7 & 7 & 7 & Horizontal & Monopólio & Pública & $\operatorname{Pax}$ & 100 \\
\hline Finlândia & 5,6 & 8 & 8 & Horizontal & Monopólio & Pública & $\operatorname{Pax}$ & 100 \\
\hline Alemanha & 5,5 & 9 & 9 & Vertical & Infraestrutura & Púb. \& Priv. & $\begin{array}{c}\text { Cargas \& } \\
\text { Pax }\end{array}$ & 99 \\
\hline Espanha & 5,5 & 10 & 10 & Horizontal & Infraestrutura & Púb. \& Priv. & $\operatorname{Pax}$ & 74 \\
\hline $\begin{array}{l}\text { Estados } \\
\text { Unidos }\end{array}$ & 5,5 & 11 & 11 & Vertical & Rotas & Púb. \& Priv. & Carga & 100 \\
\hline Taiwan & 5,3 & 12 & 12 & Vertical & Monopólio & Pública & $\operatorname{Pax}$ & 69 \\
\hline Canadá & 4,9 & 13 & 16 & Vertical & Rotas & Púb. \& Priv. & Carga & 100 \\
\hline China & 4,8 & 14 & 17 & Vertical & Monopólio & Pública & Misto & 99 \\
\hline Reino Unido & 4,7 & 15 & 19 & Horizontal & Monopólio & Púb. \& Priv. & Pax & 98 \\
\hline Rússia & 4,5 & 16 & 23 & Vertical & Monopólio & Pública & Carga & 99 \\
\hline Índia & 4,4 & 17 & 28 & Vertical & Monopólio & Pública & $\begin{array}{c}\text { Cargas \& } \\
\text { Pax }\end{array}$ & 85 \\
\hline Austrália & 4,1 & 18 & 35 & Ambos & Rotas \& Infra. & Púb. \& Priv. & $\begin{array}{c}\text { Cargas \& } \\
\text { Pax }\end{array}$ & 51 \\
\hline Argentina & 2,1 & 19 & 83 & Vertical & Monopólio & Pública & $\begin{array}{c}\text { Cargas \& } \\
\text { Pax }\end{array}$ & 71 \\
\hline Brasil & 2 & 20 & 88 & Vertical & Monopólio & Privada & Carga & 82 \\
\hline Média/Moda & 5,06 & & Moda: & Vertical & Monopólio & Pública & Pax & 88 \\
\hline
\end{tabular}

A hipótese nula é que a qualidade é a mesma em todas as variáveis. A hipótese alternativa é que a qualidade não é a mesma em cada variável. Portanto, o teste Kruskal-Wallis é realizado para cada variável apresentada na tabela 6.2. Como resultado, observa-se, na tabela 6.2, que os países de qualidade da infraestrutura superior são dedicados ao mercado de transporte de passageiros. A característica do modelo, vertical ou horizontal, e a forma de competição monopolista, por rotas ou pela infraestrutura - não são estatisticamente divergentes na amostra dos países selecionados. As características de propriedade e a unificação da bitola na rede também não são diferentes na amostra. Outra forma de interpretar os dados é observando que há correlação entre dedicação ao mercado de transporte de passageiros e a alta qualidade da infraestrutura ferroviária. 
Tabela 6.2 Resultado teste Kruskal-Wallis para a qualidade da infraestrutura

\begin{tabular}{cccc}
\hline Variável & $\mathrm{H}$ & P-valor & Característica Dominante \\
\hline Integração & 3,97 & 0,137 & - \\
Competição & 2,96 & 0,397 & - \\
Propriedade & 2,79 & 0,247 & - \\
Mercado & 10,51 & 0,005 & Mercado de Passageiros \\
UB $(\%)$ & 0,00 & 0,940 & - \\
\hline
\end{tabular}

\subsubsection{Características Associadas à Extensão}

Na tabela 6.3, são observados os países analisados, ordenados pela extensão total da malha ferroviária, segundo CIA (2017). Na coluna Posição, têm-se a colocação do país na amostra (A) deste estudo e a colocação do país na população (P), no ranking da CIA (2017), com 136 países. As demais colunas são as mesmas da tabela 6.1.

Tabela 6.3 Países amostrados ordenados pela extensão total da malha

\begin{tabular}{|c|c|c|c|c|c|c|c|c|}
\hline \multirow{2}{*}{ País } & \multirow{2}{*}{$\begin{array}{l}\text { Extensão } \\
(\mathbf{k m})\end{array}$} & \multicolumn{2}{|c|}{ Posição } & \multirow{2}{*}{ Integração } & \multirow{2}{*}{ Competição } & \multirow{2}{*}{ Propriedade } & \multirow{2}{*}{ Mercado } & \multirow{2}{*}{ UB (\%) } \\
\hline & & $\mathrm{A}$ & $\mathrm{P}$ & & & & & \\
\hline $\begin{array}{l}\text { Estados } \\
\text { Unidos }\end{array}$ & 293.564 & 1 & 1 & Vertical & Rotas & Púb. \& Priv. & Cargas & 100 \\
\hline China & 191.270 & 2 & 2 & Vertical & Monopólio & Pública & $\begin{array}{c}\text { Cargas \& } \\
\text { Pax }\end{array}$ & 99 \\
\hline Rússia & 87.157 & 3 & 3 & Vertical & Monopólio & Pública & Cargas & 99 \\
\hline Canadá & 77.932 & 4 & 4 & Vertical & Rotas & Púb. \& Priv. & Cargas & 100 \\
\hline Índia & 68.525 & 5 & 5 & Vertical & Monopólio & Pública & $\begin{array}{c}\text { Cargas \& } \\
\text { Pax }\end{array}$ & 85 \\
\hline Alemanha & 43.468 & 6 & 6 & Vertical & Infraestrutura & Púb. \& Priv. & $\begin{array}{c}\text { Cargas \& } \\
\text { Pax }\end{array}$ & 99 \\
\hline Austrália & 36.968 & 7 & 7 & Ambos & $\begin{array}{c}\text { Rotas \& } \\
\text { Infraestrutura }\end{array}$ & Púb. \& Priv. & $\begin{array}{c}\text { Cargas \& } \\
\text { Pax }\end{array}$ & 51 \\
\hline Argentina & 36.917 & 8 & 8 & Vertical & Monopólio & Pública & $\begin{array}{c}\text { Cargas \& } \\
\text { Pax }\end{array}$ & 71 \\
\hline França & 29.640 & 9 & 9 & Horizontal & Infraestrutura & Púb. \& Priv. & Pax & 99 \\
\hline Brasil & 28.538 & 10 & 10 & Vertical & Monopólio & Privada & Cargas & 82 \\
\hline Japão & 27.311 & 11 & 11 & Vertical & Rotas & Púb. \& Priv. & Pax & 80 \\
\hline Reino Unido & 16.837 & 12 & 16 & Horizontal & Monopólio & Púb. \& Priv. & Pax & 98 \\
\hline Espanha & 16.102 & 13 & 17 & Horizontal & Infraestrutura & Púb. \& Priv. & Pax & 74 \\
\hline Finlândia & 5.919 & 14 & 32 & Horizontal & Monopólio & Pública & Pax & 100 \\
\hline Suíça & 5.652 & 15 & 33 & Horizontal & Monopólio & Pública & Pax & 80 \\
\hline Coreia do Sul & 3.460 & 16 & 52 & Horizontal & Monopólio & Pública & Pax & 100 \\
\hline Holanda & 3.223 & 17 & 56 & Horizontal & Infraestrutura & Pública & Pax & 100 \\
\hline Taiwan & 1.597 & 18 & 79 & Vertical & Monopólio & Pública & Pax & 69 \\
\hline Cingapura & 241 & 19 & - & Vertical & Monopólio & Pública & Pax & 88 \\
\hline Hong Kong & 210 & 20 & - & Vertical & Monopólio & Púb. \& Priv. & Pax & 88 \\
\hline Média/Moda & 48.727 & & Moda: & Vertical & Monopólio & Pública & Pax & 88 \\
\hline
\end{tabular}

A hipótese nula é que a extensão é a mesma em todas as variáveis. A hipótese alternativa é que a extensão total da malha não é a mesma em cada variável. Novamente, o teste KruskalWallis é realizado para cada variável apresentada na tabela 6.4. Como resultado, observa-se 
que os países com maior extensão da malha são dedicados ao mercado de transporte de cargas. As demais variáveis observadas não têm predominância na amostra dos países selecionados.

Tabela 6.4 Resultado teste Kruskal-Wallis para a extensão total da malha

\begin{tabular}{cccc}
\hline Variável & $\mathrm{H}$ & P-valor & Característica Superior \\
\hline Integração & 3,22 & 0,199 & - \\
Competição & 3,31 & 0,346 & - \\
Propriedade & 0,83 & 0,658 & - \\
Mercado & 13,65 & 0,001 & Mercado de Cargas \\
UB $(\%)$ & 2,52 & 0,112 & - \\
\hline
\end{tabular}

\subsubsection{Características Associadas à Densidade}

Na tabela 6.5, são observados os países analisados, ordenados pela densidade total da malha ferroviária. As demais colunas são as mesmas das tabelas 6.1 e 6.3.

Tabela 6.5 Países amostrados ordenados pela densidade total da malha

\begin{tabular}{|c|c|c|c|c|c|c|c|}
\hline País & $\begin{array}{c}\begin{array}{c}\text { Extensão } \\
(\mathbf{k m})\end{array} \\
\end{array}$ & $\begin{array}{c}\text { Posição } \\
\text { Amostra } \\
\end{array}$ & Integração & Competição & Propriedade & Mercado & UB (\%) \\
\hline Cingapura & 337,7 & 1 & Vertical & Monopólio & Pública & Pax & 88 \\
\hline Hong Kong & 191,0 & 2 & Vertical & Monopólio & Púb. \& Priv. & Pax & 88 \\
\hline Suíça & 141,3 & 3 & Horizontal & Monopólio & Pública & Pax & 80 \\
\hline Alemanha & 124,7 & 4 & Vertical & Infraestrutura & Púb. \& Priv. & Misto & 99 \\
\hline Holanda & 95,1 & 5 & Horizontal & Infraestrutura & Pública & Pax & 100 \\
\hline Japão & 74,9 & 6 & Vertical & Rotas & Púb. \& Priv. & Pax & 80 \\
\hline Reino Unido & 69,6 & 7 & Horizontal & Monopólio & Púb. \& Priv. & Pax & 98 \\
\hline Taiwan & 49,5 & 8 & Vertical & Monopólio & Pública & Pax & 69 \\
\hline França & 46,3 & 9 & Horizontal & Infraestrutura & Púb. \& Priv. & Pax & 99 \\
\hline Coreia do Sul & 35,7 & 10 & Horizontal & Monopólio & Pública & Pax & 100 \\
\hline Espanha & 32,3 & 11 & Horizontal & Infraestrutura & Púb. \& Priv. & Pax & 74 \\
\hline $\begin{array}{l}\text { Estados } \\
\text { Unidos }\end{array}$ & 32,1 & 12 & Vertical & Rotas & Púb. \& Priv. & Cargas & 100 \\
\hline Índia & 23,1 & 13 & Vertical & Monopólio & Pública & Misto & 85 \\
\hline China & 20,5 & 14 & Vertical & Monopólio & Pública & Misto & 99 \\
\hline Finlândia & 19,5 & 15 & Horizontal & Monopólio & Pública & Pax & 100 \\
\hline Argentina & 13,5 & 16 & Vertical & Monopólio & Pública & Misto & 71 \\
\hline Canadá & 8,6 & 17 & Vertical & Rotas & Púb. \& Priv. & Cargas & 100 \\
\hline Rússia & 5,3 & 18 & Vertical & Monopólio & Pública & Cargas & 99 \\
\hline Austrália & 4,8 & 19 & Ambos & $\begin{array}{c}\text { Rotas \& } \\
\text { Infraestrutura }\end{array}$ & Púb. \& Priv. & Misto & 51 \\
\hline Brasil & 3,4 & 20 & Vertical & Monopólio & Privada & Cargas & 82 \\
\hline Média: & 66,4 & Moda: & Vertical & Monopólio & Pública & Pax & 88 \\
\hline
\end{tabular}

A hipótese nula é que a densidade da malha ferroviária é a mesma em todas as variáveis. A hipótese alternativa é que a densidade não é a mesma em cada variável. Novamente, o teste Kruskal-Wallis é realizado para cada variável apresentada na tabela 6.6. Como resultado, 
observa-se que os países com maior densidade da malha são dedicados ao mercado de transporte de passageiros. As demais variáveis observadas não têm características dominantes na amostra selecionada.

Tabela 6.6 Resultado teste Kruskal-Wallis para a densidade total da malha

\begin{tabular}{cccc}
\hline Variável & $\mathrm{H}_{\text {. }}$ & P-valor & Característica Superior \\
\hline Integração & 3,45 & 0,178 & - \\
Competição & 3,39 & 0,335 & - \\
Propriedade & 2,76 & 0,251 & - \\
Mercado & 9,35 & 0,009 & Mercado de Passageiros \\
UB $(\%)$ & 0,20 & 0,650 & - \\
\hline
\end{tabular}

Não há evidências que um ou outro modelo de organização das ferrovias, forma de competição por cargas e/ou passageiros, tipo de propriedade das ferrovias ou mesmo existência de uma única bitola na rede seja uma característica decisiva entre os benchmarks em termos de qualidade, extensão e densidade. Em termos de eficácia, todos os modelos podem conduzir a bons resultados, a única diferença relevante entre as opções estaria no custo, qual modelo geraria menor custo ou mesmo maior receita líquida para a sociedade.

\subsection{LEVANTAMENTO DOS ATORES}

\subsubsection{Perfil dos Participantes.}

A primeira variável pesquisada no levantamento diz respeito a que tipo de ator interessado o respondente mais se identifica em relação ao setor ferroviário. O estrato de maior adesão à pesquisa se deu entre atores interessados identificados com a academia, 21,7\%, seguido de usuários, 17,4\%; governo, 14,5\%; outros interesses não identificados previamente, 13\%; legisladores, 10,1\%; reguladores e controladores foram 8,7\% cada; concessionários ferroviários foram $4,3 \%$ e operadores ferroviários independentes $1,4 \%$, conforme se observa na figura a 6.1 . 


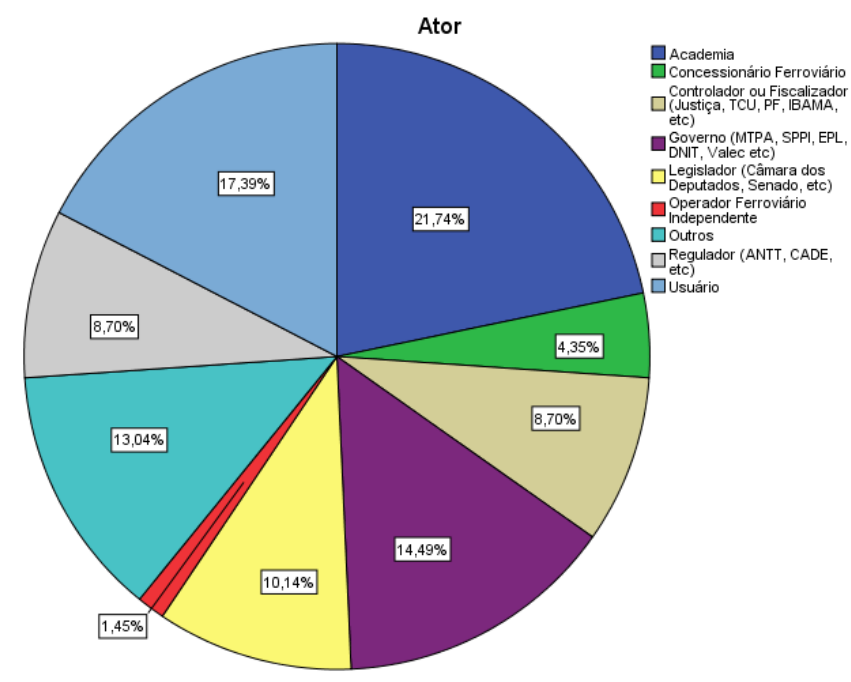

Figura 6.1 Divisão dos participantes por tipo de ator mais identificado

Uma vez que a estratificação se mostrou demasiada em relação ao pequeno número de participantes, os dados foram reclassificados pelo tipo de motivação de agir, interesse público, para os atores vinculados a atores governamentais ou interesse privado, para atores vinculados a atores do mercado. Os atores identificados com a academia e sem prévia identificação foram mantidos, de maneira que foram formadas quatro classes de estudo, em função do interesse: "acadêmico", "privado", "público" ou "não classificado" no setor ferroviário. A tabela 6.7 ilustra a reclassificação dos respondentes.

Tabela 6.7 Classificação das respostas pelas variáveis "Ator interessado" e "Tipo de interesse"

\begin{tabular}{cccc}
\hline Entrada: Ator & Frequência & Saída: Interesse & Frequência \\
\hline Academia & 15 & Acadêmico & $15(21,74 \%)$ \\
\hline Concessionário Ferroviário & 3 & & \\
Operador Ferroviário & 1 & Privado & $16(23,19 \%)$ \\
Independente & 12 & & \\
Usuário & 12 & & \\
\hline
\end{tabular}

Controlador ou Fiscalizador

(Justiça, TCU, PF, IBAMA,

6

etc)

Governo (MTPA, SPPI, EPL,

DNIT, Valec etc)

Público

$29(42,03 \%)$

Legislador (Câmara dos

Deputados, Senado, etc)

Regulador (ANTT, CADE,

etc)

6

\begin{tabular}{cccc}
\hline Outros & 9 & Não classificado & $9(13,04 \%)$ \\
\hline Total & $\mathbf{6 9}$ & Total & $\mathbf{6 9}(\mathbf{1 0 0 , 0 0 \% )}$ \\
\hline
\end{tabular}


Dessa forma, os atores identificados com interesses estatais (público) no setor ferroviário representam $42 \%$ da amostragem, atores identificados com interesses do mercado (privado) remontam 23\%, atores identificados com a academia (acadêmico) são 21,7\% e atores cuja identificação não foi previamente identificada (não classificado) remontam 13\% da amostra, conforme ilustrado na figura 6.2.

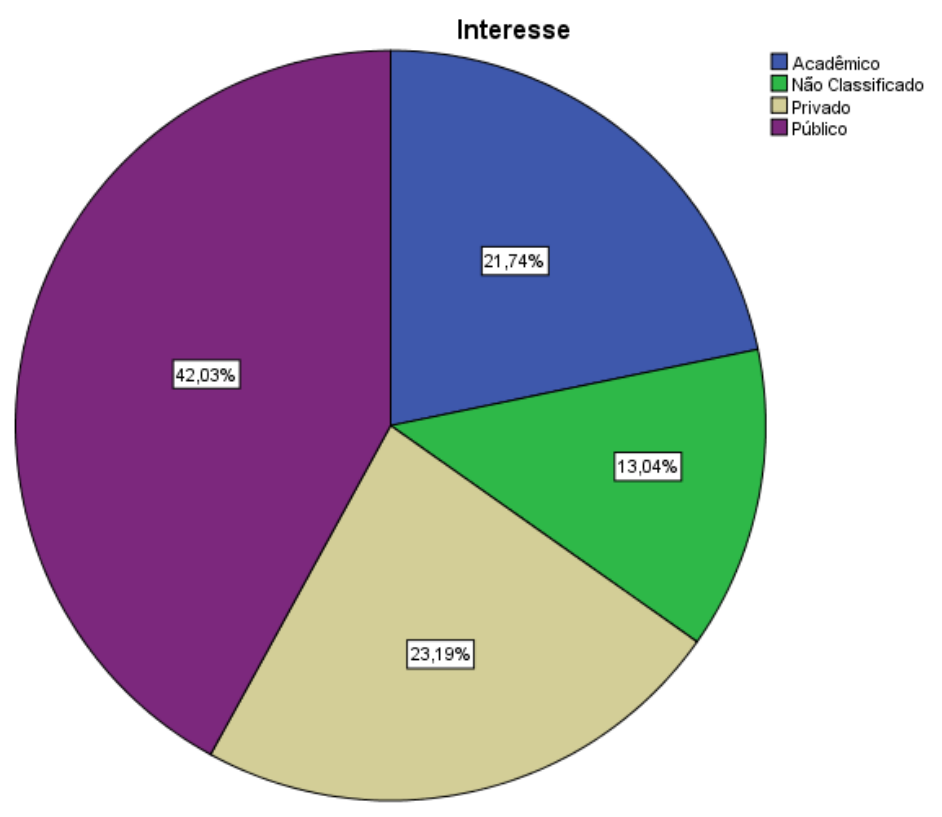

Figura 6.2 Divisão dos entrevistados por tipo de interesse

Outro aspecto característico do perfil dos atores interessados do estudo é a formação acadêmica, figura 6.3. A formação em engenharia é comum a 43,5\% dos entrevistados. Direito foi a formação declarada por $13 \%$ dos participantes. Os que se declaram com formação em Economia também representaram 13\% dos participantes. Administração foi a formação declarada por $8,7 \%$ dos participantes. A pesquisa não conseguiu prever a área de formação de $21,7 \%$ dos participantes. 


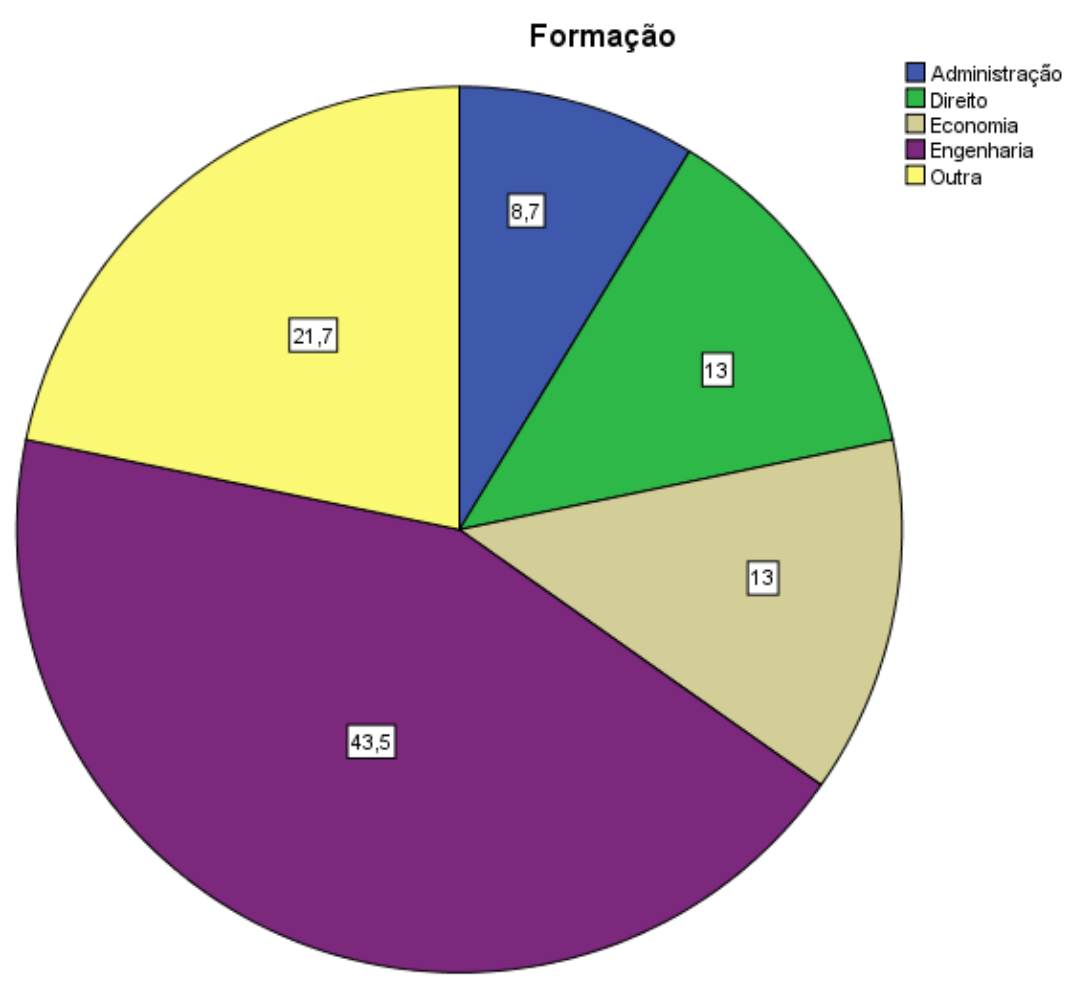

Figura 6.3 Divisão dos entrevistados por área de formação

Quanto à instrução dos entrevistados, figura 6.4, 29\% declararam possuir apenas graduação, 26,1\% declararam possuir especialização, mesmo percentual dos que declararam possuir mestrado. Doutorado foi o nível de instrução declarado por 15,9\% dos entrevistados, sendo que 2,9\% declarou possuir pós-doutorado. Embora a instrução em nível médio existisse como opção no formulário de pesquisa não houve autodeclaração de instrução nesse nível. 


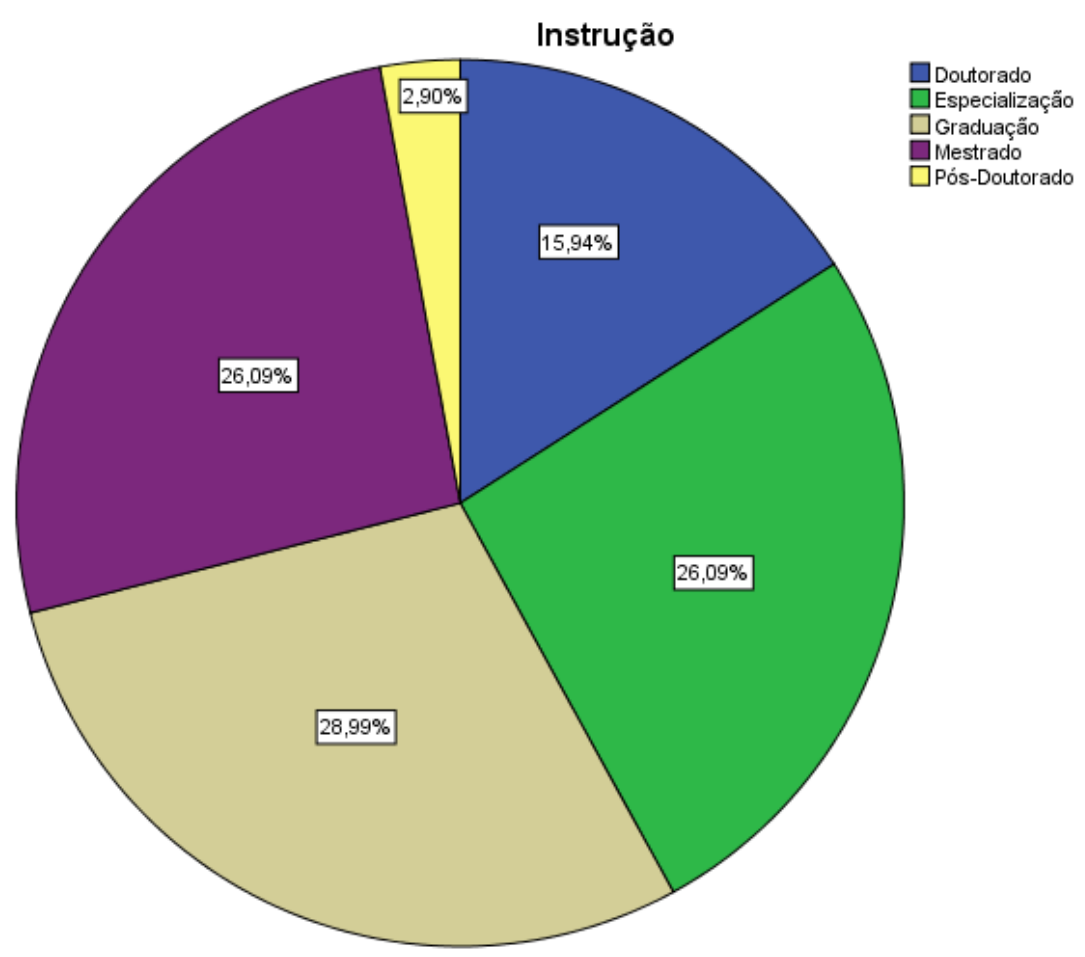

Figura 6.4 Divisão dos entrevistados por instrução

Com relação aos anos de experiência no setor ferroviário - figura 6.5, de forma agregada a maioria declarou possuir mais de 1 ano de experiência $(54,4 \%)$, entretanto, o estrato mais significativo do estudo é o de menos de 1 ano de experiência, com 46,6\% dos entrevistados. $\mathrm{O}$ segundo estrato de maior frequência no levantamento é o de 1 a 5 anos de experiência com 26,09\%. O terceiro estrato em frequência é o de 6 a 10 anos de experiência com 13,04\%, seguido pelos que declararam possuir experiência entre 11 a 15, com 5,8\%, 16 a 20, com $2,9 \%$ e 21 a 25 com 1,45\%, respectivamente. Por último, o estrato com mais de 25 anos de experiência foi declarado por $4,35 \%$ dos entrevistados. 


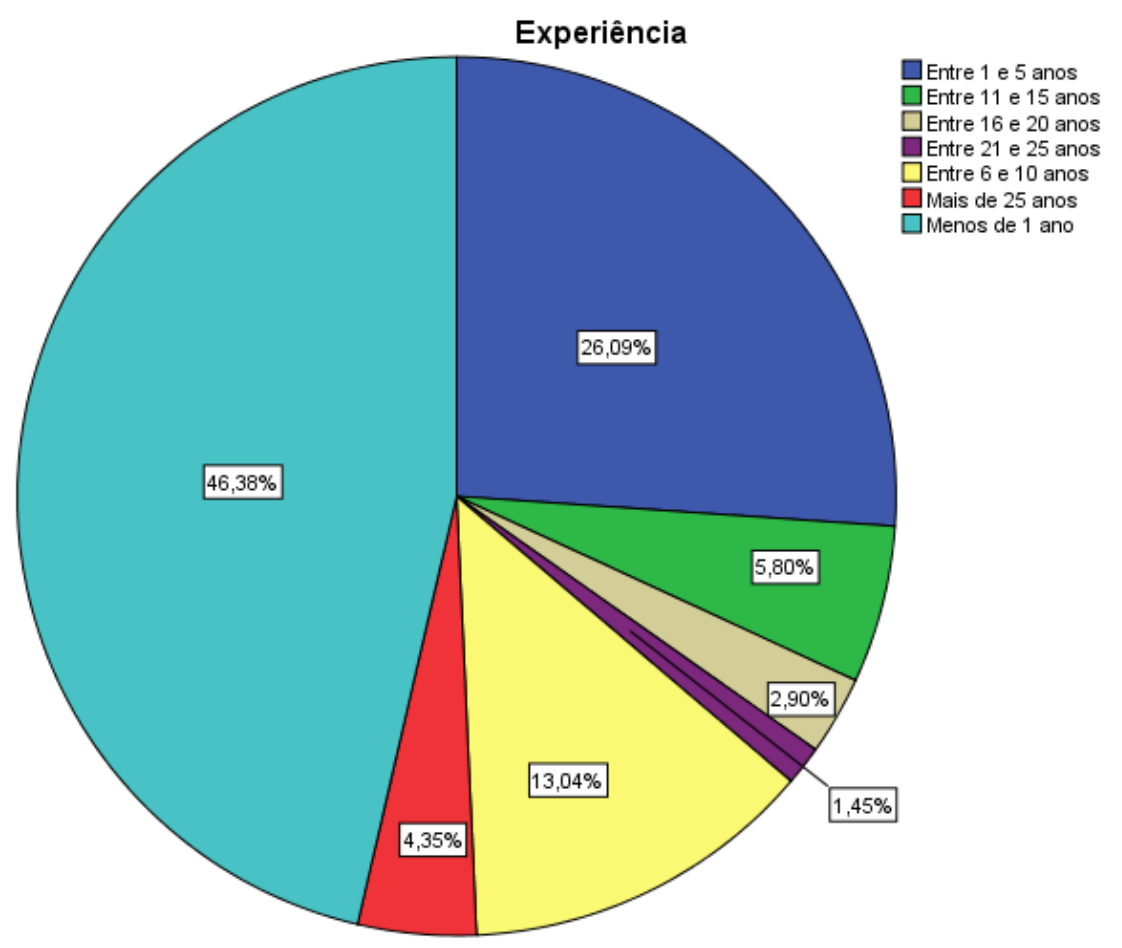

Figura 6.5 Divisão dos entrevistados por anos de experiência no setor ferroviário

Na Figura 6.6 é possível observar que a estratificação da experiência dos entrevistados obedece um modelo hierárquico piramidal bem definido, em que os estratos de menor experiência estão na base da pirâmide em número maior que o estrato imediatamente superior. Possivelmente, esse fenômeno se repetiria se o estrato com mais de 25 anos de experiência tivesse sido classificado em mais subclasses.

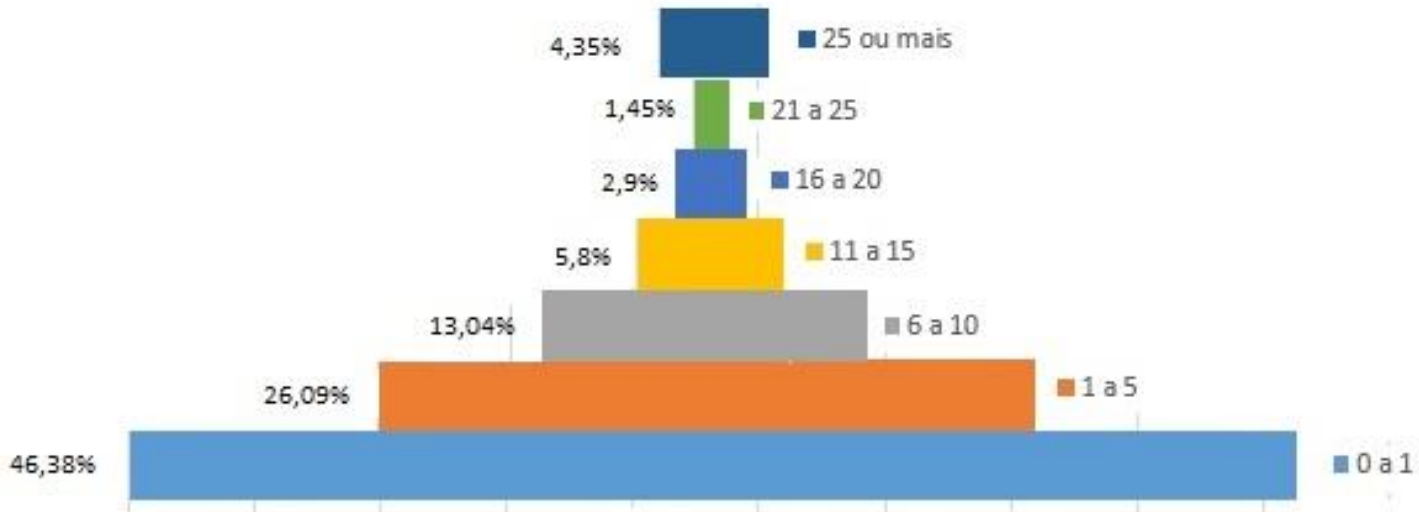

Figura 6.6 Divisão piramidal do tempo de experiência 


\subsubsection{Avaliação do Setor Ferroviário}

A pesquisa procurou avaliar o setor ferroviário brasileiro por meio de algumas dimensões logísticas e econômicas, segundo a percepção dos entrevistados. Os entrevistados foram solicitados a declarar o grau de cada variável em uma escala de 1 a 6 . As estatísticas descritivas gerais dessa avaliação estão ilustradas na tabela 6.8, a seguir:

Tabela 6.8 Estatísticas descritivas das variáveis sobre a avaliação geral do setor ferroviário

\begin{tabular}{lcccccccc}
\hline \multicolumn{1}{c}{ Variável } & N & mín. & máx. & média & desvio padrão & variância & mediana & moda \\
\hline Extensão & 69 & 1 & 5 & 1,84 & 0,994 & 0,989 & 2 & 1 \\
Qualidade & 68 & 1 & 4 & 2,15 & 0,778 & 0,605 & 2 & 2 \\
Quantidade da oferta & 69 & 1 & 6 & 1,78 & 0,968 & 0,937 & 2 & 1 \\
Demanda & 69 & 1 & 6 & 4,14 & 1,407 & 1,979 & 4 & 4 \\
Rentabilidade & 66 & 1 & 6 & 3,42 & 1,138 & 1,294 & 3 & 4 \\
Preços & 64 & 1 & 6 & 3,98 & 1,161 & 1,349 & 4 & 4 \\
Concorrência Intermodal & 68 & 1 & 6 & 4,01 & 1,723 & 2,970 & 4,5 & 5 \\
Concorrência Intramodal & 68 & 1 & 5 & 1,81 & 1,026 & 1,052 & 1,5 & 1 \\
Participação Privada & 67 & 1 & 6 & 2,81 & 1,373 & 1,886 & 3 & 3 \\
Participação do Estado & 67 & 1 & 6 & 2,93 & 1,663 & 2,767 & 3 & 1 \\
Intervenção regulatória & 68 & 1 & 6 & 3,25 & 1,722 & 2,966 & 3 & 1 \\
\hline
\end{tabular}

De forma geral, a avaliação dos pesquisados foi de que a malha ferroviária é pouco extensa com média 1,84 e desvio padrão 0,994 com 69 entrevistados. Não foi fornecida nenhuma informação sobre a extensão teórica da rede, que é de cerca de 30 mil km de trilhos, ou sobre a extensão efetiva da rede que é de cerca de $10 \mathrm{mil} \mathrm{km} \mathrm{em} \mathrm{operação.} \mathrm{Quanto} \mathrm{à} \mathrm{qualidade} \mathrm{da}$ infraestrutura, a percepção foi pessimista, com média 2,15 e desvio padrão 0,778 com 68 entrevistados. Esses dados são convergentes com os relatórios de WEF (2015, 2016 e 2017). A percepção, também foi pessimista quanto a quantidade da oferta de serviços de transporte ferroviários, com média 1,78 e desvio padrão 0,968 para 69 entrevistados. A demanda por serviços de transporte ferroviário foi declarada como em quantidade elevada, com média 4,14 e desvio padrão 1,407 para 69 entrevistados. A rentabilidade das empresas ferroviárias foi declarada como pouco elevada com média 3,14 e desvio padrão 1,138 para 66 entrevistados.

A percepção dos pesquisados declarada sobre os preços dos fretes ferroviários foi que esses são elevados, com média 3,98 e desvio padrão 1,161 para 64 entrevistados. Na prática, os preços de fretes ferroviários no Brasil variam entre 50\% (Turtelli, 2017) ${ }^{85}$ a $95 \%$ do frete rodoviário.

\footnotetext{
${ }^{85}$ Segundo Turtelli, Fernando Paes, diretor executivo da Associação Nacional de Transportadores Ferroviários, teria dito no fórum Logística e Infraestrutura no Agronegócio, realizado em 8 de novembro de 2017, que o frete ferroviário equivale a 50\% do rodoviário, $\mathrm{R} \$ 78,96$ ante $\mathrm{R} \$ 140,00$ por TKU.
} 
Quanto a concorrência, a avaliação dos pesquisados foi de que a concorrência intermodal é elevada com média 4,01 e desvio padrão 1,723 para 68 entrevistados e a concorrência intramodal é baixa com média 1,81 e desvio padrão 1,026 para 68 entrevistados. Essa opinião pode ser explicada pelo resultado histórico das concessões dos anos de 1990, que acabaram resultando em monopólios ferroviários geográficos. A única região do país onde pode existir alguma concorrência entre concessionárias ferroviárias é no entorno de Belo Horizonte. As demais regiões do país, a concorrência ocorre apenas entre as modalidades, com vantagem para o modo rodoviário, que consegue ser um serviço substituto com eficácia, exceto para o transporte de minério de ferro.

Quanto à participação privada no setor ferroviário, a percepção declarada dos pesquisados foi que a iniciativa privada participa pouco, com média 2,81 e desvio padrão 1,373 para 67 entrevistados. Mesma percepção foi declarada para a participação estatal, baixa com média 2,93 e desvio padrão 1,663 para 67 entrevistados. Tanto o estado quanto o mercado atuam pouco no setor ferroviário, na opinião dos entrevistados. Não obstante, a intervenção regulatória é alta com média 3,25 e desvio padrão 1,722 na opinião de 68 entrevistados.

A percepção dos entrevistados foi testada, por meio do teste de Kruskal-Wallis, com nível de significância de 95\%, em relação às áreas de interesse dos pesquisados. Não foram observadas opiniões estatisticamente divergentes, como pode ser observado nas tabelas 6.9 e 6.10 :

Tabela 6.9 Cotejo da percepção dos entrevistados por área de interesse

\begin{tabular}{lcccccccc}
\hline \multirow{2}{*}{ Interesse } & \multicolumn{2}{c}{ acadêmico } & \multicolumn{2}{c}{ privado } & \multicolumn{2}{c}{ público } & \multicolumn{2}{c}{ não classificado } \\
\cline { 2 - 9 } & média & mediana & média & mediana & média & mediana & média & mediana \\
\hline Extensão & 2,07 & 2 & 2,07 & 2 & 1,75 & 1,5 & 1,43 & 1 \\
Qualidade & 2,07 & 2 & 2,27 & 2 & 2 & 2 & 2,29 & 3 \\
Quantidade da oferta & 1,86 & 2 & 2,07 & 2 & 1,67 & 1 & 1,57 & 1 \\
Demanda & 3,93 & 4 & 4,87 & 5 & 3,79 & 4 & 3,71 & 4 \\
Rentabilidade & 3,64 & 4 & 3,47 & 4 & 3,46 & 3 & 2,86 & 3 \\
Preços & 4,07 & 4 & 4,27 & 4 & 3,88 & 4 & 3,43 & 4 \\
Concorrência Intermodal & 3,93 & 4 & 3,80 & 4 & 4,29 & 5 & 3,43 & 3 \\
Concorrência Intramodal & 2,00 & 2 & 1,67 & 2 & 1,96 & 2 & 1,43 & 1 \\
Participação Privada & 2,86 & 3 & 2,60 & 2 & 2,79 & 2 & 2,86 & 2 \\
Participação do Estado & 3,36 & 3 & 3,00 & 2 & 2,88 & 2,5 & 3,00 & 3 \\
Intervenção regulatória & 3,57 & 3,5 & 3,87 & 4 & 2,88 & 4 & 2,88 & 2 \\
\hline
\end{tabular}

Aliás, como pode ser visto, na tabela 6.10, a única percepção declarada que ficou próxima de uma divergência estatística foi a demanda, considerada mais elevada pelos atores interessados vinculados ao setor privado, em relação a opinião dos demais atores interessados. 
Tabela 6.10 Resultado dos testes estatísticos acerca das divergências de opiniões por áreas de interesse

\begin{tabular}{|c|c|c|}
\hline Variável & $\mathrm{H}$ & p-valor \\
\hline Extensão & 3,590 & 0,309 \\
\hline Qualidade & 0,307 & 0,959 \\
\hline Quantidade da oferta & 2,284 & 0,516 \\
\hline Demanda & 7,654 & 0,054 \\
\hline Rentabilidade & 3,069 & 0,381 \\
\hline Preços & 1,653 & 0,647 \\
\hline Concorrência Intermodal & 1,642 & 0,650 \\
\hline Concorrência Intramodal & 2,799 & 0,424 \\
\hline Participação Privada & 2,607 & 0,456 \\
\hline Participação do Estado & 0,931 & 0,818 \\
\hline Intervenção regulatória & 3,371 & 0,338 \\
\hline
\end{tabular}

Pela percepção dos entrevistados, não foi possível observar opiniões divergentes acerca dos onze pilares estudados nesta pesquisa. A exceção da variável demanda, que apresenta a maior divergência de percepção entre o setor público e privado, ainda assim não significativa estatisticamente. As demais dez dimensões estudadas são convergentes entre os estratos identificados com o setor público, privado e acadêmico.

Extensão da malha, quantidade da oferta e concorrência intramodal foram as dimensões com as avaliações mais baixas. Por outro lado, a concorrência intermodal, os preços de frete e a demanda foram consideradas as dimensões com avaliações mais altas. A figura 6.7 ilustra a síntese da avaliação geral.

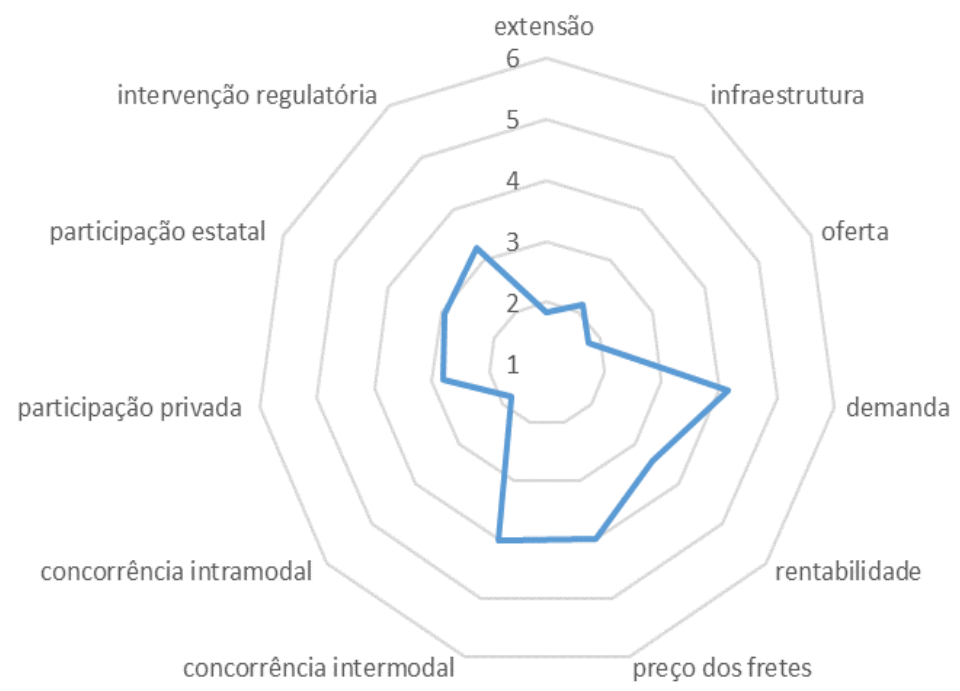

Figura 6.7 Síntese da avaliação geral entre os onze pilares pesquisados 


\subsection{CRITICIDADE DOS RISCOS}

Deseja-se nesta avaliação investigar a percepção dos atores interessados quantos aos riscos de implantação inerentes ao sistema ferroviário por meio do NPR. Com base no levantamento do estudo de caso, o NPR foi calculado separadamente para o transporte ferroviário de cargas e de passageiros, cujos dados estatísticos descritivos estão relacionados nas tabelas 6.11 e 6.12: Por meio de testes estatísticos não paramétricos, será verificado se o NPR é o mesmo em todos os riscos levantados. Isto é, a hipótese nula é que o NPR não difere com relação aos riscos estudados. Assim, a hipótese alternativa é que pelo menos um risco difere dos demais em relação ao NPR calculado.

Tabela 6.11 Estatísticas descritivas do NPR do Setor de Transporte Ferroviário de Cargas

\begin{tabular}{|c|c|c|c|c|c|c|}
\hline Riscos levantados & 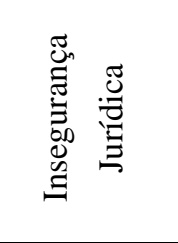 & 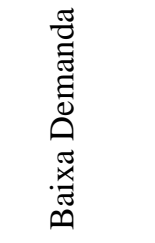 & 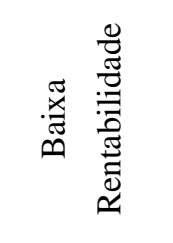 & 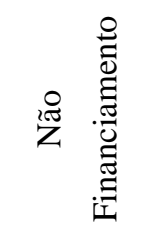 & 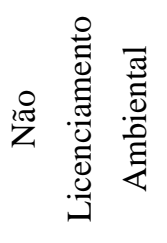 & 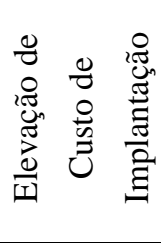 \\
\hline \multirow[t]{5}{*}{$\mathrm{N}$} & 59 & 59 & 59 & 51 & 58 & 59 \\
\hline & 10 & 10 & 10 & 18 & 11 & 10 \\
\hline & 240,4174 & 129,1801 & 132,0953 & 180,8260 & 269,5388 & 249,0530 \\
\hline & 182,8750 & 91,8750 & 105,8750 & 144,3750 & 226,8750 & 226,8750 \\
\hline & 309,38 & $91,88^{\mathrm{a}}$ & 91,88 & 144,38 & $196,88^{a}$ & 309,38 \\
\hline Desvio Padrão & 188,66199 & 93,78309 & 115,49340 & 126,62149 & 191,66581 & 146,40301 \\
\hline Variância & 35593,347 & 8795,267 & 13338,726 & 16033,003 & 36735,784 & 21433,843 \\
\hline Amplitude & 854,00 & 493,00 & 854,00 & 673,50 & 673,50 & 673,50 \\
\hline Mínimo & 3,38 & 3,38 & 3,38 & 3,38 & 3,38 & 3,38 \\
\hline Máximo & 857,38 & 496,38 & 857,38 & 676,88 & 676,88 & 676,88 \\
\hline Percentis & 91,8750 & 49,8750 & 67,3750 & 105,8750 & 106,8750 & 135,3750 \\
\hline 50 & 182,8750 & 91,8750 & 105,8750 & 144,3750 & 226,8750 & 226,8750 \\
\hline 75 & 309,3750 & 182,8750 & 166,3750 & 226,8750 & 399,3750 & 315,8750 \\
\hline
\end{tabular}

a. Existe mais de uma moda, a menor foi apresentada 
Tabela 6.12 Estatísticas descritivas do NPR do Setor de Transporte Ferroviário de Passageiros

\begin{tabular}{|c|c|c|c|c|c|c|c|}
\hline \multicolumn{2}{|c|}{ Riscos levantados } & 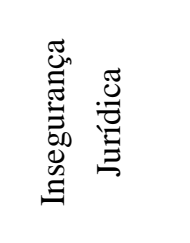 & 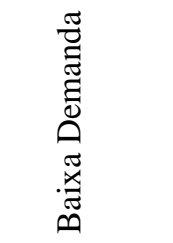 & 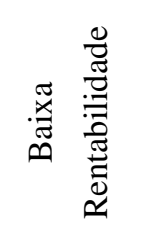 & 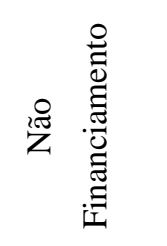 & 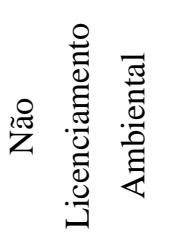 & 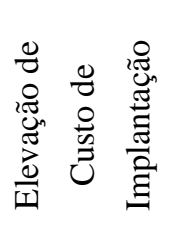 \\
\hline \multirow[t]{10}{*}{$\mathrm{N}$} & Válidos & 58 & 60 & 60 & 60 & 60 & 60 \\
\hline & Não opinou & 11 & 9 & 9 & 9 & 9 & 9 \\
\hline & Média & 209,9871 & 154,4167 & 187,2917 & 180,0250 & 221,6583 & 240,0333 \\
\hline & Mediana & 174,6250 & 106,8750 & 155,3750 & 139,8750 & 166,3750 & 196,8750 \\
\hline & Moda & 196,88 & 91,88 & 67,38 & 226,88 & 166,38 & 196,88 \\
\hline & Desvio Padrão & 185,46719 & 126,14621 & 148,13199 & 157,34555 & 187,91603 & 190,28254 \\
\hline & Variância & 34398,079 & 15912,867 & 21943,086 & 24757,621 & 35312,435 & 36207,445 \\
\hline & Amplitude & 854,00 & 673,50 & 854,00 & 854,00 & 854,00 & 854,00 \\
\hline & Mínimo & 3,38 & 3,38 & 3,38 & 3,38 & 3,38 & 3,38 \\
\hline & Máximo & 857,38 & 676,88 & 857,38 & 857,38 & 857,38 & 857,38 \\
\hline \multirow[t]{3}{*}{ Percentis } & 25 & 67,3750 & 67,3750 & 86,2500 & 84,3750 & 86,2500 & 105,8750 \\
\hline & 50 & 174,6250 & 106,8750 & 155,3750 & 139,8750 & 166,3750 & 196,8750 \\
\hline & 75 & 264,3750 & 226,8750 & 249,3750 & 226,8750 & 315,8750 & 314,2500 \\
\hline
\end{tabular}

Para identificar qual ou quais riscos são diferentes quanto ao nível de criticidade medido pelo NPR, foi utilizado o teste de Milton Friedman. O S calculado para o transporte de cargas e passageiros tem, em ambos os casos, $\mathrm{k}=6$, mas $\mathrm{N}$ varia em cada situação, pois houve mais respostas válidas no transporte de passageiros em relação ao de cargas. Para o cálculo da estatística $\mathrm{S}$ de Friedman a variável dos $k$ tratamentos (riscos) tem que ser avaliada por cada um dos $\mathrm{N}$ blocos (atores interessados). No transporte de cargas tem-se $N=50$ e no transporte Passageiros tem-se $\mathrm{N}=58$, como consta da tabela 6.13:

Tabela 6.13 Resultado do teste de Friedman para o PNR dos setores ferroviários de carga e passageiros:

\begin{tabular}{c|c|c|c|c|c|c|c|c}
\hline Teste de Friedman & Sistema Ferroviário & $N$ & $g l$ & $X^{2}$ & $x$-crítico & $p$-valor & sig & $\alpha$ \\
\hline$S_{\text {Calculado }}$ & Cargas & 50 & 5 & 42,987 & 11,07 & $3,72 \mathrm{E}-8$ & $\operatorname{sim}$ & $5 \%$ \\
\hline$S_{\text {Calculado }}$ & Passageiros & 58 & 5 & 19,096 & 11,07 & 0,002 & $\operatorname{sim}$ & $5 \%$ \\
\hline
\end{tabular}

A tabela 6.14, apresenta os $\mathrm{k}=6$ tratamentos, juntamente com o somatório dos ranks $\left(\sum \mathrm{R}_{\mathrm{i}}\right)$ de cada tratamento, e o rank médio de cada tratamento, a ordenação dos tratamentos em função dos riscos, no menor para o maior, e as estatísticas do NPR de medidas centrais, média e mediana. É importante salientar que dentro de cada bloco, a posição foi atribuída do menor NPR para o maior, assim, os menores $R_{i}$ indicam as menores criticidades. Pela tabela 6.14 é possível observar, por meio da coluna Posição $\left(R_{i}\right)$ que o risco de maior criticidade é o risco de elevação dos custos de implantação (6), seguido do risco de não licenciamento ambiental 
(5), insegurança jurídica (4), sucessivamente até o risco de menor criticidade, baixa rentabilidade (1). Observa-se na tabela 6.14 que as medidas centrais, média e mediana, são falsos indicadores da ordem de criticidade. Mas esses riscos são estatisticamente diferentes uns dos outros? A estatística $\mathrm{S}$ de Friedman já apontou que sim. Todavia, ainda se faz necessário verificar qual risco é diferente dos demais.

Tabela 6.14 Ranks acumulados do teste de Friedman para o NPR do transporte ferroviário de cargas

\begin{tabular}{lcccccc}
\multicolumn{1}{c}{ Tratamentos } & $\mathrm{N}$ & $\sum \mathrm{R}_{\mathrm{i}}$ & $\mathrm{R}_{\mathrm{i}}$ médio & $\begin{array}{c}\text { Posição } \\
\left(\mathrm{R}_{\mathrm{i}}\right)\end{array}$ & $\begin{array}{c}\text { NPR } \\
(\text { média })\end{array}$ & $\begin{array}{c}\text { NPR } \\
(\text { mediana })\end{array}$ \\
\hline Risco de baixa rentabilidade & 50 & 129,5 & 2,59 & 1 & 132,0 & 105,8 \\
Risco de baixa demanda & 50 & 134,5 & 2,69 & 2 & 129,1 & 91,8 \\
Risco de não financiamento & 50 & 173,5 & 3,47 & 3 & 180,8 & 144,3 \\
$\begin{array}{l}\text { Risco de insegurança jurídica } \\
\text { Risco de não licenciamento }\end{array}$ & 50 & 187,5 & 3,75 & 4 & 240,4 & 182,8 \\
ambiental & 50 & 203,5 & 4,07 & 5 & 269,5 & 226,8 \\
$\begin{array}{l}\text { Risco de elevação dos custos de } \\
\text { implantação }\end{array}$ & 50 & 221,5 & 4,43 & 6 & 249,0 & 226,8 \\
\hline
\end{tabular}

Na tabela 6.15 é efetuada a comparação dos k tratamentos, dois a dois, a fim de se verificar quais são os estatisticamente diferentes dos demais. Pode-se observar que não existe diferença estatística suficiente entre o tratamento de posição (3) risco de não financiamento e o tratamento de posição (6) risco de elevação de custos de implantação. Ao mesmo tempo é seguro afirmar que os riscos de posição (1) baixa rentabilidade e (2) baixa demanda são diferentes estatisticamente dos riscos de posição (5) e (6) da tabela 6.15.

Tabela 6.15 Comparações múltiplas do NPR do transporte ferroviário de cargas

\begin{tabular}{ccccccc}
\hline Posição i & Posição j & $\mathbf{R i}$ & $\mathbf{R j}$ & $|\mathbf{R i}-\mathbf{R} \mathbf{j}|$ & $\boldsymbol{\Delta}$ & Diferente \\
\hline 6 & 1 & 221,5 & 129,5 & 92,0 & 61,0 & sim \\
6 & 2 & 221,5 & 134,5 & 87,0 & 61,0 & sim \\
6 & 3 & 221,5 & 173,5 & 48,0 & 61,0 & não \\
5 & 1 & 203,5 & 129,5 & 74,0 & 61,0 & sim \\
5 & 2 & 203,5 & 134,5 & 69,0 & 61,0 & sim \\
5 & 3 & 203,5 & 173,5 & 30,0 & 61,0 & não \\
4 & 1 & 187,5 & 129,5 & 58,0 & 61,0 & não \\
\hline
\end{tabular}

Segundo a Fogliatto (2003) é desejável atuar em todos os riscos de criticidade com NPR $\geq 50$. Assim, todos os 6 seis riscos do estudo de caso deveriam ser tratados, no entanto, priorizando a ordem de criticidade da tabela 6.14, do maior para o menor. Repetindo-se o processo aplicado ao transporte ferroviário de cargas, os ranks acumulados e diferenças críticas do NPR do transporte ferroviário de passageiros estão elencados nas tabelas 6.16 e 6.17, respectivamente. 
Tabela 6.16 Ranks acumulados do teste de Friedman para o NPR do transporte ferroviário de passageiros

\begin{tabular}{|c|c|c|c|c|c|c|}
\hline Tratamentos & $\mathrm{N}$ & $\sum \mathrm{R}_{\mathrm{i}}$ & $\mathrm{R}_{\mathrm{i}}$ médio & $\begin{array}{c}\text { Posição } \\
\left(\mathrm{R}_{\mathrm{i}}\right)\end{array}$ & $\begin{array}{c}\text { NPR } \\
\text { (média) }\end{array}$ & $\begin{array}{c}\text { NPR } \\
\text { (mediana) }\end{array}$ \\
\hline Risco de baixa demanda & 58 & 172,2 & 2,97 & 1 & 154,4 & 106,8 \\
\hline Risco de não financiamento & 58 & 178,0 & 3,07 & 2 & 180,0 & 139,8 \\
\hline Risco de insegurança jurídica & 58 & 199,5 & 3,44 & 3 & 209,9 & 174,6 \\
\hline $\begin{array}{l}\text { Risco de não licenciamento } \\
\text { ambiental }\end{array}$ & 58 & 206,4 & 3,56 & 4 & 221,6 & 166,3 \\
\hline Risco de baixa rentabilidade & 58 & 221,5 & 3,82 & 5 & 187,2 & 155,3 \\
\hline $\begin{array}{l}\text { Risco de elevação dos custos de } \\
\text { implantação }\end{array}$ & 58 & 240 & 4,15 & 6 & 240,0 & 196,8 \\
\hline
\end{tabular}

Na tabela 6.17 é possível observar que são diferentes entre si apenas os riscos de posição (6) e (1), respectivamente, elevação de custos de implantação e baixa demanda. Esse resultado é convergente com o resultado exposto na tabela 6.13, em que o p-valor do transporte de cargas foi expressivamente inferior ao do transporte de passageiros. Esse resultado também é compatível com a realidade brasileira em que o transporte de passageiros é inexpressivo em relação ao transporte de cargas. Assim, é natural que as percepções dos atores interessados sejam menos significativas no transporte de passageiros em relação ao transporte de cargas.

Tabela 6.17 Comparações múltiplas do NPR do transporte ferroviário de pasageiros

\begin{tabular}{ccccccc}
\hline Posição i & Posição j & $\mathbf{R i}$ & $\mathbf{R j}$ & $\mathbf{R i}-\mathbf{R j}$ & $\boldsymbol{\Delta}$ & Diferente \\
\hline 6 & 1 & 240,7 & 172,3 & 68,4 & 65,7 & sim \\
6 & 2 & 240,7 & 178,1 & 62,6 & 65,7 & não \\
5 & 1 & 221,6 & 172,3 & 49,3 & 65,7 & não \\
\hline
\end{tabular}

Os resultados da análise da criticidade dos riscos são favoráveis a adoção do modelo integralmente privado, mais no transporte de cargas que no de passageiros. Para os atores interessados, os riscos de baixa demanda e não financiamento são baixos em ambos os mercados, todavia, o risco de baixa rentabilidade no mercado de passageiros é percebido como elevado. Ocorre, que a experiência internacional aponta que esse risco pode ser mitigado com as receitas assessórias advindas da exploração imobiliária. Essa solução, contudo, no Brasil, é negligenciada.

O risco de maior criticidade percebido em ambos os mercados foi o de elevação dos custos de implantação. Devido à falta de incentivos à eficiência no setor público, essa percepção dos atores interessados também é favorável a adoção da ferrovia integralmente privada.

\subsection{FERROVIAS COMPARADAS}

Deseja-se nesta avaliação testar a percepção dos atores interessados quanto a afirmação de Takasaki (2014) de que a escolha de um modelo de exploração ferroviária depende de 
características intrínsecas da ferrovia ${ }^{86} \mathrm{e}$, não, necessariamente, a melhor opção envolve a escolha de um único modelo para todas as ferrovias. Assim, por meio de testes estatísticos não paramétricos, é verificado se a proporção de indivíduos em cada estrato das variáveis analisadas é a mesma nas dez diferentes ferrovias levantadas. A hipótese nula é que as ferrovias não diferem com relação as variáveis estudadas. A hipótese alternativa é que pelo menos uma ferrovia difere das demais em relação as variáveis estudadas. No caso desta pesquisa, as variáveis de interesse foram a titularidade das ferrovias, o direito de exploração da malha quanto ao compartilhamento da rede, o critério de outorga nos casos de concessão, a bitola de operação, a utilidade da ferrovia, a viabilidade econômica e, por fim, a prioridade de investimento.

Foram aplicados o teste $X^{2}$ (qui-quadrado) de heterogeneidade de Karl Pearson e o teste de soma de posições (sum rank test) de Milton Friedman. Como resultado observou-se que as variáveis: titularidade, exploração, outorga e bitola são homogêneas em relação as ferrovias estudas no teste $X^{2}$. Isto é, não se rejeita H0, como pode ser observado na tabela 6.18:

Tabela 6.18 Variáveis homogêneas $(\alpha=5 \%)$ para as ferrovias do estudo

\begin{tabular}{ccccc}
\hline Teste $\boldsymbol{Q u i - Q u a d r a d o}$ & $\boldsymbol{g l}$ & $\boldsymbol{X}^{\mathbf{2}}$ & $\boldsymbol{x}$-crítico & $\boldsymbol{p}$-valor \\
\hline Titularidade & $2 \times 9$ & 17,4317 & 28,8693 & 0,49363 \\
\hline Exploração & $3 \times 9$ & 7,0053 & 40,1132 & 0,99996 \\
\hline Outorga & $4 \times 9$ & 18,7015 & 50,9984 & 0,99996 \\
\hline Bitola & $3 \times 9$ & 16,9048 & 40,1132 & 0,93344 \\
\hline
\end{tabular}

As tabelas de frequência das variáveis homogêneas estão apresentadas no Apêndice B.

\subsubsection{Variáveis Homogêneas}

\subsubsection{Titularidade}

$\mathrm{O}$ resultado contraria a expectativa de que determinadas ferrovias do estudo poderiam ser percebidas como mais propícias à exploração integralmente privada, como por exemplo a EF170 Ferrogrão (Miritituba - Sinop) ou o Ferroanel de São Paulo. Ou mesmo que ferrovias supostamente menos rentáveis, contudo estratégicas para a diminuição de desigualdades regionais poderiam ser percebidas como mais propícias para exploração integralmente pública, como a EF-334 entre Ilhéus e Figueirópolis ou EF-354 FICO entre o Acre-Goiás. A preferência declarada de $26 \%$, integralmente privadas, $65 \%$, concessão e $9 \%$ integralmente públicas foi considerado homogêneo, entre as 10 ferrovias. Esse resultado comparado com o de Resende et al. (2009) revela que a preferência pela participação privada se manteve

\footnotetext{
${ }^{86}$ Takasaki (2014) cita explicitamente: tráfego, escala, densidade e demandas de mercado.
} 
constante e inverteu-se a preferência entre concessão e participação estatal. A opinião dos usuários em Resende et al. (2009) foi que a iniciativa privada deveria ser responsável pela gestão das ferrovias para $28 \%$ dos entrevistados. Entretanto, a preferência pela participação integralmente pública (governo), em Resende et al. (2009), era de $52 \%$ e a concessão era preferida por apenas $15 \%$ dos entrevistados. O confronto desses dois resultados indica uma descrença na atuação estatal, no setor ferroviário, na opinião de parte dos atores interessados.

\subsubsection{Exploração}

O open access foi a escolha de $38 \%$ dos entrevistados. Resultado muito significativo uma vez que nunca foi adotado na prática no cenário brasileiro, apesar de ter vigorado, em teoria, entre 2013 e 2016, durante a vigência do Decreto $n^{\circ} 8.129$, de 2013, revogado pelo Decreto 8.875, de 2016. O modelo de integração vertical com compartilhamento da malha - tráfego mútuo, 13\%, e direito de passagem, $40 \%$ - foi a opção de 53\% dos entrevistados. $9 \%$ ainda manifestou preferência pela integração vertical com exclusividade de tráfego. Esse resultado contraria a expectativa que determinadas ferrovias do estudo poderiam ser percebidas como mais propícias à exploração integralmente vertical ou integralmente horizontal. Esperava-se, que a EF-170, entre Sinop e Miritituba, por ser, atualmente, isolada tivesse uma resposta maior que as demais quanto a possibilidade de exploração integralmente vertical.

\subsubsection{Outorga}

O critério de maior valor de outorga privada, praticado nas concessões dos anos 1990, foi escolhido por apenas $25 \%$ dos respondentes que declararam opinião válida sobre o tema. A opção "menor tempo de exploração" foi a preferida por 0,005\%. Possivelmente contribuiu para a baixíssima adesão o entendimento dominante de que os investimentos ferroviários são de longo prazo, às vezes, com payback maiores que os prazos de duração da concessão. Nesses casos a concorrência por menor tempo de exploração poderia levar a desincentivos de investimentos, já que os prazos pactuados não seriam suficientes para adequada recuperação do capital investido. Aliás, a insuficiência de prazos adequados para recuperação de capital investido foi uma alegação presente no Brasil, Argentina e Reino Unido, apresentada pelas firmas ferroviárias, mesmo em leilões decididos por outros critérios.

Cerca de $15 \%$ optaram pelo critério de menor contraprestação pública, possivelmente indicando a percepção da alternativa de concessões patrocinadas ou administrativas como solução para a exploração ferroviária. A maior capacidade de movimentação de carga foi opção declarada preferida por $20 \%$ dos respondentes, apesar de essa possibilidade não existir textualmente no marco regulatório atual. O critério da menor tarifa foi a opção preferida por 
$40 \%$ dos entrevistados com opiniões declaradas sobre o critério de outorga de ferrovias. A opção preferencial pelo critério de menor tarifa converge com a avaliação dos preços dos fretes exposta no subitem 6.2.2, possivelmente, por conta de o preço do mercado ferroviário ser fixado, na prática, como um percentual inferior, contudo próximo dos preços dos fretes rodoviários.

\subsubsection{Bitola}

A bitola larga foi a preferida por $64 \%$ dos entrevistados, com respostas válidas. Surpreendentemente, a bitola standard foi a opção de 13\% dos entrevistados com opiniões declaradas, embora, atualmente, essa bitola somente tenha sido empregada em menos de 200km de linhas isoladas de carga localizadas no Amapá e em ramais curtos de linhas metroviárias. Possivelmente a opção declarada pela bitola standard tenha relação com a opção internacional do mundo desenvolvido. China, parte significativa da Europa, EUA, Canadá e México adotam a bitola standard como bitola única ou preferencial. Se o Brasil tivesse adotado a bitola standard, em um eventual processo de unificação de bitolas, haveria, teoricamente, diminuição de custos de aquisição de material rodante em razão do aumento de oferta, pois não seria necessária a customização para a bitola larga ou estreita, mais usadas no Brasil. Além disso, os custos de construção em comparação com a bitola larga seriam diminuídos. Todavia, a prévia opção brasileira pela bitola larga gerou um efeito de path dependence que é difícil de ser superado. Também surpreende a baixa adesão dos entrevistados com opiniões declaradas pela bitola estreita, apenas 3\% declararam preferência por essa bitola, embora seja a bitola empregada em cerca de $88 \%$ da malha. Possivelmente, a baixa adesão a opção da bitola estreita tem relação com o baixo desempenho operacional das ferrovias nessa bitola, apesar de serem as mais numerosas e antigas da malha. A bitola mista, com três trilhos para permitir o intercâmbio de trens oriundos das bitolas larga ou estreita solução alternativa para a unificação das bitolas, como já ocorre em cerca de 1,7\% da malha, a exemplo das imediações do porto de Santos - foi a opção de $20 \%$ dos entrevistados.

\subsubsection{Variáveis Heterogêneas}

Por outro lado, as variáveis utilidade, viabilidade e prioridade são heterogenias em relação as ferrovias no teste $X^{2}$. Segundo Callegari-Jacques (2003), no máximo 20\% dos valores esperados nas categorias (E) poderiam ser inferiores a 5 e nenhum valor esperado poderia ser menor que 1 em cada célula. Em ambos os casos, com e sem aglutinação, a rejeição da hipótese nula é expressiva, como pode ser visto na tabela 6.19: 
Tabela 6.19 Resultado do teste $X^{2}$ das variáveis heterogêneas para as ferrovias do estudo

\begin{tabular}{lcrrr}
\hline \multicolumn{1}{c}{ Teste Qui-Quadrado } & $\boldsymbol{g l}$ & $\boldsymbol{X}^{\mathbf{2}}$ & $\boldsymbol{x}$-crítico & $\boldsymbol{p}$-valor \\
\hline Utilidade sem aglutinação de célula & $4 \times 9$ & 103,8791 & 50,99846 & $1,67 \mathrm{E}-08$ \\
Utilidade com aglutinação de célula & $3 \times 9$ & 95,8109 & 40,11327 & $1,6 \mathrm{E}-10$ \\
Viabilidade sem aglutinação de célula & $4 \times 9$ & 125,2739 & 50,99846 & $8,44 \mathrm{E}-12$ \\
Viabilidade com aglutinação de célula & $3 \times 9$ & 117,5739 & 40,11327 & $2,84 \mathrm{E}-13$ \\
Prioridade sem aglutinação de célula & $4 \times 9$ & 106,4143 & 50,99846 & $7,00 \mathrm{E}-9$ \\
Prioridade com aglutinação de célula & $3 \times 9$ & 92,02658 & 40,11327 & $5,04 \mathrm{E}-9$ \\
\hline
\end{tabular}

A rejeição de H0 foi, em seguida confirmada no teste de Friedman, com $\alpha=5 \%$, como pode ser observado na tabela 6.20:

Tabela 6.20 Resultado do teste de Friedman das variáveis heterogêneas para as ferrovias do estudo

\begin{tabular}{lrrrr}
\hline \multicolumn{1}{c}{ Teste Friedman } & $\boldsymbol{g l}$ & $\boldsymbol{X}^{\mathbf{2}}$ & $\boldsymbol{x}$-crítico & $\boldsymbol{p}-$ valor \\
\hline Utilidade sem ajuste de empates & 9 & 50,99852 & 16,92 & $7,03 \mathrm{E}-8$ \\
Utilidade com ajustes de empates & 9 & 86,24688 & 16,92 & $9,19 \mathrm{E}-15$ \\
Viabilidade sem ajuste de empates & 9 & 47,30413 & 16,92 & $3,44 \mathrm{E}-7$ \\
Viabilidade com ajustes de empates & 9 & 74,78833 & 16,92 & $1,74 \mathrm{E}-12$ \\
Prioridade sem ajuste de empates & 9 & 32,9776 & 16,92 & 0,000135 \\
Prioridade com ajustes de empates & 9 & 47,0013 & 16,92 & $3,92 \mathrm{E}-7$ \\
\hline
\end{tabular}

\subsubsection{Utilidade}

Pela primeira vez na pesquisa as respostas são dependentes de cada ferrovia analisada no estudo, segundo o teste $X^{2}$ e confirmadas no teste de Friedman, com $\mathrm{N}=37$ e $\alpha=5 \%$, e $\Delta=84,9$, segundo ilustrado na tabela 6.21 , a seguir:

Tabela 6.21 Frequência e ranking da variável utilidade para as 10 ferrovias estudadas

\begin{tabular}{|c|c|c|c|c|c|c|c|c|c|c|}
\hline & 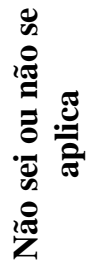 & 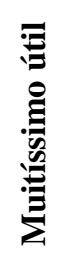 & 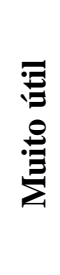 & 蒠 & 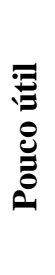 & 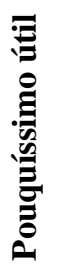 & 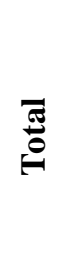 & $\sum \mathbf{R}_{\mathbf{i}}$ & $\begin{array}{c}\mathbf{R}_{\mathbf{i}} \\
\text { médio }\end{array}$ & Posição \\
\hline Ferroanel - São Paulo & 18 & 34 & 14 & 2 & 0 & 1 & 69 & 142,0 & 3,838 & 1 \\
\hline $\begin{array}{l}\text { Rumo-ALL } \\
\text { Paulista) }\end{array}$ & 17 & 35 & 11 & 5 & 0 & 1 & 69 & 145,5 & 3,932 & 2 \\
\hline $\begin{array}{l}\text { MRS (Santos }- \text { Belo } \\
\text { Horizonte) }\end{array}$ & 17 & 37 & 11 & 3 & 0 & 1 & 69 & 148,0 & 4,000 & 3 \\
\hline EF-151 FNS - Ferrovia & & & & & & & & & & \\
\hline $\begin{array}{l}\text { Norte Sul (Palmas - } \\
\text { Estrela d'Oeste) }\end{array}$ & 22 & 20 & 13 & 10 & 2 & 2 & 69 & 180,0 & 4,865 & 4 \\
\hline $\begin{array}{l}\text { Ferrovia Intercidades - } \\
\text { Campinas - Santos }\end{array}$ & 22 & 22 & 12 & 8 & 4 & 1 & 69 & 207,5 & 5,608 & 5 \\
\hline EF-170 Ferrogrão & 22 & 20 & 13 & 10 & 2 & 2 & 69 & 209,0 & 5,649 & 6 \\
\hline
\end{tabular}




\begin{tabular}{|c|c|c|c|c|c|c|c|c|c|c|}
\hline & 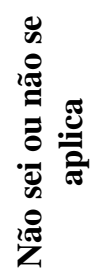 & 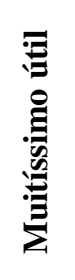 & 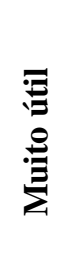 & 票 & 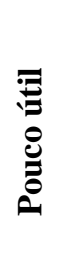 & 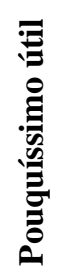 & $\stackrel{5}{\stackrel{5}{0}}$ & $\sum \mathbf{R}_{\mathbf{i}}$ & $\underset{\text { médio }}{\mathbf{R}_{\mathbf{i}}}$ & Posição \\
\hline (Miritituba - Sinop) & & & & & & & & & & \\
\hline $\begin{array}{l}\text { EF-334 FIOL - Ferrovia } \\
\text { de Integração Oeste Leste } \\
\text { (Ilhéus Figueirópolis) }\end{array}$ & 21 & 12 & 16 & 12 & 5 & 3 & 69 & 227,0 & 6,135 & 7 \\
\hline $\begin{array}{l}\text { EF-354 FICO - Ferrovia } \\
\text { Integração Centro-Oeste } \\
\text { (Acre-Goiás) }\end{array}$ & 24 & 13 & 10 & 15 & 6 & 1 & 69 & 247,5 & 6,689 & 8 \\
\hline $\begin{array}{l}\text { Ferrovia Transpequi } \\
\text { (Brasília-Goiânia) }\end{array}$ & 21 & 12 & 8 & 14 & 9 & 5 & 69 & 260,5 & 7,041 & 9 \\
\hline Nova Transnordestina & 18 & 12 & 14 & 15 & 9 & 1 & 69 & 268,0 & 7,243 & 10 \\
\hline
\end{tabular}

Das 6 ferrovias declaradas como mais úteis apenas duas são operacionais, Rumo-ALL (malha paulista) e MRS Santos a Belo Horizonte, ambas em tratativas para terem seus contratos renovados antecipadamente, a fim de aumentar os investimentos. A ferrovia EF-151 Norte Sul ainda não é operacional, está em fase de preparação de leilão de concessão. O Ferroanel de São Paulo é um projeto ainda embrionário apesar de ter sido incluído no PIL. A ferrovia Intercidades é um projeto também embrionário incluído recentemente no projeto Crescer do governo federal. Finalmente, a ferrovia Ferrogrão, entre Sinop e Miritituba, é um projeto greenfield também incluído no projeto Crescer.

Das 4 ferrovias "menos úteis" na percepção dos entrevistados, o governo federal tem investido no planejamento e execução na razão de meio a meio. Brasília a Goiânia está em fase de estudo de viabilidade conduzido pela ANTT (ANTT, 2017). A EF-354 FICO está em fase de estudos conduzidos pela VALEC e faz parte dos estudos do grupo de trabalho BrasilChina-Peru. A EF-334 FIOL está em fase de construção pela VALEC. Por sua vez, a Nova Transnordestina está em construção em uma parceria entre a VALEC e o grupo CSN.

\subsubsection{Viabilidade Econômica}

Pela segunda vez na pesquisa, as respostas são dependentes de cada ferrovia analisada no estudo, segundo o teste $X^{2}$ e confirmadas no teste de Friedman, com $\mathrm{N}=33$ e $\alpha=5 \%$, e $\Delta=80,2$, segundo ilustrado na tabela 6.22 .

No caso da variável viabilidade, as ferrovias percebidas como mais viáveis foram: o Ferroanel de São Paulo, a malha paulista da Rumo-ALL, a ferrovia entre Santos e Belo Horizonte da MRS, a ferrovia EF-151 entre Palmas e Estrela d'Oeste, a ferrogrão entre Sinop e Miritituba e a ferrovia intercidades entre Campinas e Santos. Enquanto as ferrovias consideradas menos 
viáveis foram, na ordem: a EF-354 FICO, a EF-334-FIOL, a Nova Transnordestina, e a ferrovia Brasília a Goiânia. A deficiência brasileira em priorizar as ferrovias de maior viabilidade econômica explica, em parte, a evolução da rede ferroviária. Pode-se observar, empiricamente, aliás, que essa variável é tão ou mais relevante que a titularidade, conforme se infere da experiência americana, chinesa e brasileira.

Tabela 6.22 Frequência da variável viabilidade para as 10 ferrovias estudadas

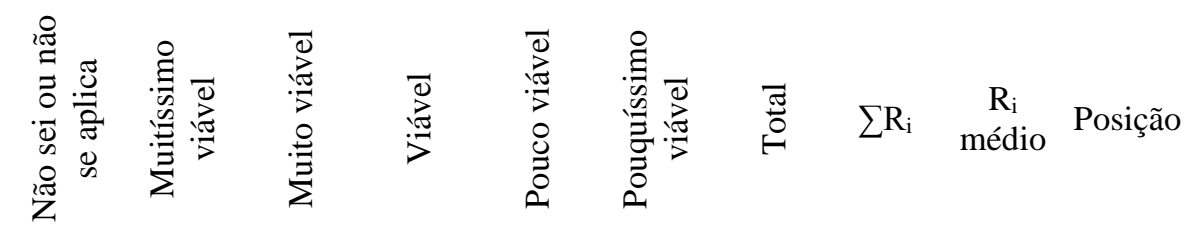

\begin{tabular}{lcccccccccc}
\hline Ferroanel - São Paulo & 24 & 24 & 11 & 8 & 1 & 1 & 69 & 114,5 & 3,470 & 1 \\
$\begin{array}{l}\text { Rumo-ALL } \\
\text { (Malha Paulista) }\end{array}$ & 23 & 24 & 12 & 9 & 1 & 0 & 69 & 118,5 & 3,591 & 2 \\
$\begin{array}{l}\text { MRS } \\
\text { (Santos - Belo Horizonte) }\end{array}$ & 24 & 26 & 7 & 10 & 2 & 0 & 69 & 128,5 & 3,894 & 3 \\
$\begin{array}{l}\text { EF-151 FNS } \\
\text { (Palmas - Estrela d'Oeste) }\end{array}$ & 30 & 10 & 7 & 19 & 3 & 0 & 69 & 166,8 & 5,056 & 4 \\
$\begin{array}{l}\text { EF-170 Ferrogrão } \\
\text { (Miritituba- Sinop) }\end{array}$ & 31 & 9 & 7 & 18 & 2 & 2 & 69 & 170,5 & 5,167 & 5 \\
$\begin{array}{l}\text { Ferrovia Intercidades } \\
\text { (Campinas - Santos) }\end{array}$ & 28 & 10 & 14 & 11 & 5 & 1 & 69 & 197,3 & 5,980 & 6 \\
$\begin{array}{l}\text { Ferrovia Transpequi } \\
\text { (Brasília- Goiânia) }\end{array}$ & 29 & 6 & 9 & 10 & 9 & 6 & 69 & 197,8 & 5,995 & 7 \\
$\begin{array}{l}\text { Nova Transnordestina } \\
\text { EF-334 FIOL }\end{array}$ & 30 & 3 & 8 & 12 & 12 & 4 & 69 & 229,8 & 6,965 & 8 \\
(Ilhéus - Figueirópolis) & 34 & 6 & 6 & 10 & 11 & 2 & 69 & 234,5 & 7,106 & 9 \\
$\begin{array}{l}\text { EF-354 FICO } \\
\text { (Acre-Goiás) }\end{array}$ & 35 & 4 & 3 & 15 & 10 & 2 & 69 & 256,7 & 7,778 & 10 \\
\hline
\end{tabular}

Enquanto nos Estados Unidos sempre houve o predomínio do investimento privado sobre o investimento público, na China e no Brasil, o investimento em ferrovias sempre foi moldado pelo interesse do Estado. Somado a esse fenômeno, pode-se constatar que o maior incremento da expansão ferroviarista americana aconteceu em um período de maior viabilidade econômica das ferrovias, resultado de uma menor competição intermodal com o modo rodoviário e aquaviário (1830-1915). A partir da abertura do canal do Panamá em 1914, a rede ferroviária americana começa a experimentar sua fase de declínio, que alcança seu ponto de inversão de tendência com a desregulamentação do setor em 1980, vide figura 6.8. 


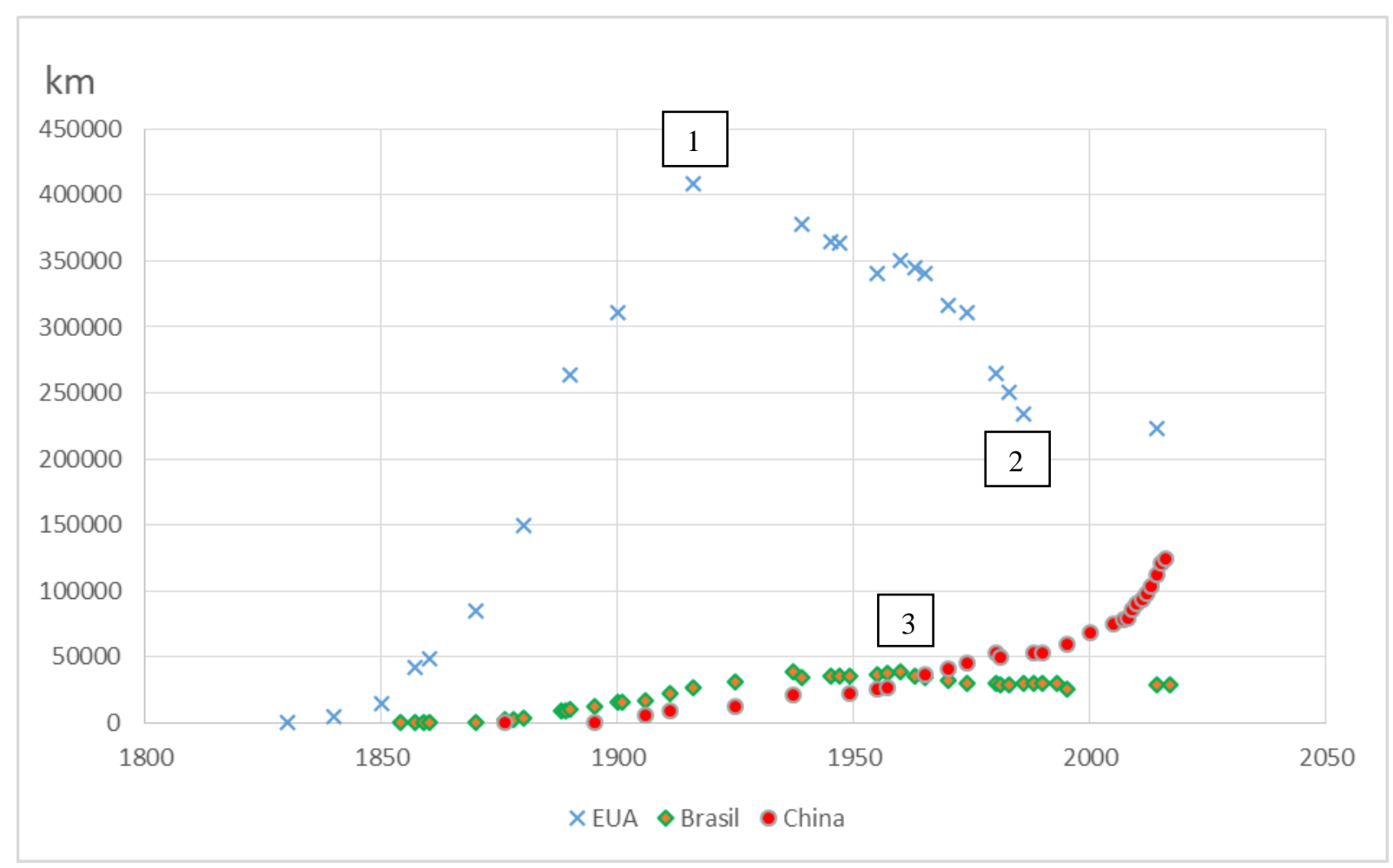

Figura 6.8 Evolução da Rede Ferroviária (EUA, Brasil, China) Legenda:

1 Abertura do canal do Panamá - 1914; 2 Desregulamentação ferroviária americana - 1981

3 Foco na expansão da rede chinesa em função da demanda de tráfego - 1979 (reforma econômica)

O resultado mais evidente dessa estratégia de exploração é que a malha ferroviária americana, sempre foi focada na maximização do atendimento da demanda de tráfego, enquanto na China, esse fenômeno só começou a ocorrer a partir de 1979 de forma bem gradual, migrando do foco de priorização estratégica, em defesa, para o de priorização da viabilidade econômica. No Brasil, esse fenômeno nunca chegou a ser plenamente vivenciado, pois, aqui a introdução de novos ramais, sempre atendeu a interesses políticos-estratégicos, e não, propriamente, interesses puramente econômicos.

\subsubsection{Prioridade}

Pela terceira vez na pesquisa, as respostas são dependentes de cada ferrovia analisada no estudo, segundo o teste $X^{2}$ e confirmadas no teste de Friedman, com $\mathrm{N}=39$ e $\alpha=5 \%$, e $\Delta=87,2$, segundo ilustrado na tabela 6.23 , a seguir: 


\begin{tabular}{|c|c|c|c|c|c|c|c|c|c|c|}
\hline & 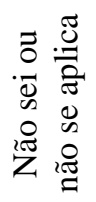 & 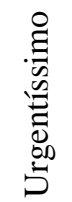 & 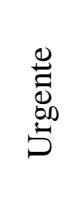 & $\begin{array}{l}\bar{\Xi} \\
\text { Ẽ } \\
\text { Z }\end{array}$ & 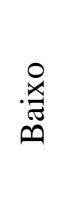 & 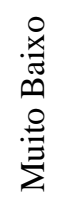 & 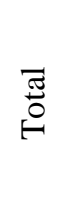 & $\sum \mathrm{R}_{\mathrm{i}}$ & $\begin{array}{l}\mathrm{R}_{\mathrm{i}} \\
\text { médio }\end{array}$ & Posição \\
\hline Ferroanel - São Paulo & 17 & 31 & 16 & 4 & 1 & 0 & 69 & 143,9 & 3,689 & 1 \\
\hline $\begin{array}{l}\text { Rumo-ALL } \\
\text { (Malha Paulista) }\end{array}$ & 16 & 23 & 19 & 8 & 0 & 3 & 69 & 160,0 & 4,103 & 2 \\
\hline $\begin{array}{l}\text { MRS } \\
\text { (Santos - Belo Horizonte) }\end{array}$ & 17 & 21 & 21 & 8 & 1 & 1 & 69 & 174,9 & 4,484 & 3 \\
\hline $\begin{array}{l}\text { EF-151 FNS } \\
\text { (Palmas - Estrela d'Oeste) }\end{array}$ & 8 & 19 & 21 & 19 & 1 & 1 & 69 & 184,5 & 4,731 & 4 \\
\hline $\begin{array}{l}\text { EF-170 Ferrogrão } \\
(\text { Miritituba - Sinop) }\end{array}$ & 20 & 13 & 19 & 13 & 1 & 3 & 69 & 204,5 & 5,244 & 5 \\
\hline $\begin{array}{l}\text { Ferrovia Intercidades } \\
\text { (Campinas - Santos) }\end{array}$ & 22 & 11 & 18 & 12 & 4 & 2 & 69 & 228,9 & 5,868 & 6 \\
\hline $\begin{array}{l}\text { Ferrovia } \quad \text { Transpequi } \\
\text { (Brasília - Goiânia) }\end{array}$ & 21 & 6 & 14 & 11 & 8 & 9 & 69 & 241,4 & 6,189 & 7 \\
\hline $\begin{array}{l}\text { EF-334 FIOL } \\
\text { (Ilhéus Figueirópolis) }\end{array}$ & 22 & 9 & 16 & 11 & 9 & 2 & 69 & 266,4 & 6,830 & 8 \\
\hline Nova Transnordestina & 18 & 11 & 15 & 14 & 8 & 3 & 69 & 267,9 & 6,868 & 9 \\
\hline $\begin{array}{l}\text { EF-354 FICO } \\
\text { (Acre-Goiás) }\end{array}$ & 24 & 7 & 12 & 16 & 8 & 2 & 69 & 272,9 & 6,996 & 10 \\
\hline
\end{tabular}

O Ferroanel de São Paulo, a malha paulista da Rumo-ALL, a ferrovia entre Santos e Belo Horizonte da MRS, a ferrovia EF-151 entre Palmas e Estrela d'Oeste e a Ferrogrão entre Sinop e Miritituba foram consideradas as ferrovias prioritárias. A mesma ordem da variável viabilidade, exceto que no caso da prioridade a estrada de ferro Intercidades ficou associada no grupo de menor prioridade. Assim, as ferrovias consideradas menos prioritárias foram, na ordem: a EF-354 FICO, a Nova Transnordestina, a EF-334-FIOL, a ferrovia Brasília a Goiânia e a ferrovia Intercidades entre Santos e Campinas. A falta de transparência na aplicação de investimentos é uma das falhas do governo no setor ferroviário. O resultado evidencia no sentido de que as prioridades do governo federal não são convergentes com a percepção dos atores interessados entrevistados neste estudo.

\subsection{HISTÓRICO DAS POLÍTICAS REGULATÓRIAS}

Todo o período de implantação das ferrovias no Brasil, sob o regime da garantia de juros, e mais tarde durante a desestatização da RFFSA foi marcado pela insuficiência do marco normativo (Acioli, 2007). As respostas históricas e tradicionais dos economistas e criadores de políticos públicas para solucionar as falhas do mercado ferroviário no mundo, fundamentadas, basicamente, na propriedade da infraestrutura ferroviária pelo Estado ou de 
uma regulação governamental mais restritiva, podem ser, em verdade, as responsáveis pelas ineficiências que as novas políticas procuram atualmente resolver (Pittman, 2011).

Neste subitem é feita uma análise dos paralelos históricos observados no desenvolvimento ferroviário do Reino Unido, Estados Unidos, China e Brasil, vide tabela 6.24.

O estatismo aplicado nesses países, embora apresente aparentes ganhos de eficiência no curto prazo, não tarda em resultar em crescentes e insustentáveis déficits no longo prazo. A ferrovia, atualmente, não tem, necessariamente, um comportamento tipicamente monopolista, pois, o transporte ferroviário tem, na maioria dos casos, substitutos alternativos em outros modos de transportes, que impedem o pleno comportamento do monopólio natural. Mesmo no recente histórico brasileiro em que as ferrovias estão organizadas em oligopólios geográficos, os preços de fretes são sempre abaixo dos preços rodoviários. Os preços só não são menores porque a competição intramodal foi praticamente abolida com as aglutinações das concessionárias ferroviárias, em parte, causada pela ação estatal. Antes da criação da RFFSA, 42 ferrovias atuavam no Brasil, atualmente apenas 3 firmas privadas "oligopolizam" o setor, controlando quase toda a rede. Fenômeno semelhante ocorreu no Reino Unido, só que não por omissão regulatória, mas de forma deliberada.

Quando a concorrência está presente, o monopólio natural de um setor pode não ter nenhum poder de monopólio (Pittman, 2011). No mercado ferroviário brasileiro, por exemplo, exceção feita ao transporte de minério de ferro, o modo rodoviário compete intensamente com o ferroviário. Pode-se dizer, à luz do histórico da matriz de transporte, que os caminhões estão avançando, apesar da concentração das firmas ferroviárias brasileiras. Enquanto a participação do modo ferroviário decresce, o monopólio da Cosan, Vale e CSN, em termos de extensão da malha ferroviária, cresce. 
Tabela 6.24 Exemplos de tradeoff entre falhas de mercado e de governo que agravaram os problemas

\begin{tabular}{|c|c|c|c|c|c|c|}
\hline Década & Local & Diagnóstico & Narrativa & Solução adotada & Resultado & Solução descartada \\
\hline 1830 & Brasil & $\begin{array}{l}\text { Mercado americano era } \\
\text { mais atraente em razão das } \\
\text { liberdades à iniciativa } \\
\text { privada. }\end{array}$ & $\begin{array}{l}\text { Os projetos de ferrovias } \\
\text { brasileiras não possuíam } \\
\text { garantias de crédito. }\end{array}$ & $\begin{array}{l}\text { Instituição de } \text { garantias de } \\
\text { juros e subvenção } \\
\text { quilométrica }^{87} \text {. }\end{array}$ & $\begin{array}{l}\text { Ineficiência na produção } \\
\text { das ferrovias. Aumento das } \\
\text { despesas da Coroa. }\end{array}$ & $\begin{array}{l}\text { Aplicar as mesmas } \\
\text { liberdades adotadas nos } \\
\text { EUA: não interferência nos } \\
\text { traçados, concessões } \\
\text { perpétuas, etc. }\end{array}$ \\
\hline 1880 & EUA & $\begin{array}{l}\text { Competição entre as } \\
\text { ferrovias desfavorecia } \\
\text { regiões agrícolas de menor } \\
\text { desenvolvimento } \\
\text { ferroviário. }\end{array}$ & $\begin{array}{l}\text { O poder monopolista } \\
\text { ferroviário gera preços } \\
\text { abusivos. }\end{array}$ & $\begin{array}{l}\text { Criação da ICC a fim de } \\
\text { regular os preços e } \\
\text { serviços ferroviários. }\end{array}$ & $\begin{array}{l}\text { Aumento médio dos } \\
\text { preços, concentração das } \\
\text { empresas ferroviárias. }\end{array}$ & $\begin{array}{l}\text { Estimular o aumento da } \\
\text { competição nas regiões } \\
\text { com déficit de oferta de } \\
\text { transporte }^{88} \text {. }\end{array}$ \\
\hline 1890 & Brasil & $\begin{array}{l}\text { Aumento das despesas com } \\
\text { o pagamento de juros às } \\
\text { ferrovias improdutivas. }\end{array}$ & $\begin{array}{l}\text { Empresas estrangeiras } \\
\text { estão explorando os cofres } \\
\text { da República. }\end{array}$ & $\begin{array}{l}\text { Nacionalização das } \\
\text { empresas concessionárias. }\end{array}$ & $\begin{array}{l}\text { Aumento das despesas e } \\
\text { diminuição da eficiência }\end{array}$ & $\begin{array}{l}\text { Repactuar os contratos ou } \\
\text { relicitar as ferrovias em } \\
\text { melhores termos }{ }^{89} \text {. }\end{array}$ \\
\hline 1920 & $\begin{array}{l}\text { Reino } \\
\text { Unido }\end{array}$ & $\begin{array}{l}\text { Integração das atividades } \\
\text { ferroviárias sob uma única } \\
\text { empresa diminui os custos } \\
\text { de transação. }\end{array}$ & $\begin{array}{l}\text { Ganhos de escala e escopo } \\
\text { aumentarão a eficiência } \\
\text { das ferrovias }\end{array}$ & $\begin{array}{l}\text { Criação de } 4 \text { firmas } \\
\text { monopolistas regionais. }\end{array}$ & $\begin{array}{l}\text { Diminuição da competição, } \\
\text { aumento de preços e } \\
\text { redução dos níveis de } \\
\text { serviço. }\end{array}$ & $\begin{array}{l}\text { Manter a competição entre } \\
\text { as firmas privadas, evitar } \\
\text { monopólios. }\end{array}$ \\
\hline 1930 & Brasil & $\begin{array}{l}\text { Estado procura fortalecer } \\
\text { sua posição dominante na } \\
\text { economia e na política } \\
\text { nacional. }\end{array}$ & $\begin{array}{l}\text { Aumento da competição } \\
\text { das rodovias afetou o } \\
\text { resultado das firmas } \\
\text { ferroviárias privadas. }\end{array}$ & $\begin{array}{l}\text { Encampação em série de } \\
\text { firmas privadas e públicas } \\
\text { estaduais. }\end{array}$ & $\begin{array}{l}\text { Aumento da expansão da } \\
\text { malha por interesses } \\
\text { estratégicos, políticos e } \\
\text { partidários. }\end{array}$ & Idem \\
\hline
\end{tabular}

\footnotetext{
${ }^{87}$ A solução mantenedora do poder político da Coroa demorou cerca de três décadas para gerar resultados.

${ }^{88}$ A desregulamentação só foi aplicada nove décadas depois.

${ }^{89}$ Solução adotada por Campos Salles na década seguinte.
} 


\begin{tabular}{|c|c|c|c|c|c|c|}
\hline Década & Local & Diagnóstico & Narrativa & Solução adotada & Resultado & Solução descartada \\
\hline 1940 & $\begin{array}{l}\text { Reino } \\
\text { Unido }\end{array}$ & $\begin{array}{lrr}\text { Burocracia } & \text { resiste } & \text { a } \\
\text { abandonar } & \text { posições } & \text { de } \\
\text { poder após o fim } & \text { da } \\
\text { Guerra. } & & \end{array}$ & $\begin{array}{l}\text { Ganhos de escala e escopo } \\
\text { aumentarão a eficiência } \\
\text { das ferrovias }\end{array}$ & $\begin{array}{lll}\text { Criação de } & \text { uma firma } \\
\text { estatal } & & \text { monopolista } \\
\text { nacional. } & & \end{array}$ & $\begin{array}{l}\text { Aumento significativo dos } \\
\text { gastos públicos e redução } \\
\text { da eficiência da produção } \\
\text { ferroviária. }\end{array}$ & Idem \\
\hline 1950 & Brasil & $\begin{array}{l}\text { Aumento da ineficiência } \\
\text { das diversas empresas } \\
\text { nacionalizadas. }\end{array}$ & Idem & Idem & Idem & Idem \\
\hline 1990 & $\begin{array}{l}\text { Reino } \\
\text { Unido }\end{array}$ & $\begin{array}{l}\text { Aumento significativo dos } \\
\text { gastos públicos e redução } \\
\text { da eficiência da produção } \\
\text { ferroviária. }\end{array}$ & $\begin{array}{l}\text { Empresas privadas são } \\
\text { mais eficientes que as } \\
\text { públicas }\end{array}$ & $\begin{array}{l}\text { Privatização das ferrovias } \\
\text { com segregação horizontal }\end{array}$ & $\begin{array}{l}\text { Continuidade do aumento } \\
\text { dos gastos públicos }\end{array}$ & $\begin{array}{l}\text { Privatização com } \\
\text { segregação geográfica, em } \\
\text { termos próximos aos de } \\
1920 .\end{array}$ \\
\hline
\end{tabular}

Fontes: Elaboração do autor. 


\section{CONSIDERAÇÕES FINAIS}

Esta pesquisa avaliou o setor ferroviário brasileiro à luz de uma comparação internacional com benchmarks globais, como Reino Unido, Estados Unidos e China, a fim de identificar e propor a incorporação das melhores estratégias adotadas entre os países analisados. O trabalho evidencia que se houver intervenção regulatória mínima e segurança jurídica suficientes, em algumas condições específicas, o mercado privado terá interesse de emergir no setor ferroviário brasileiro. Ferrovias integralmente privadas podem ocupar lacunas que o Estado não é capaz de preencher por insuficiência financeira e desinteresse natural de agir, pois, por obrigação legal, deve atuar em outras áreas prioritárias, como saúde, educação, segurança e previdência.

Além disso, o benchmarking evidência que a exploração imobiliária é um instrumento capaz de financiar novos serviços ferroviários, tanto no transporte de cargas quanto no de passageiros. Todavia, para que esse instrumento possa ser, adequadamente, aplicado, no Brasil, é preciso que o mercado seja dotado de livre capacidade de iniciativa. A maior liberdade atribuída à ferrovia privada não significa, necessariamente, a renúncia da ferrovia estatal. A evidência que se extrai do benchmarking é que o transporte ferroviário pode ser tratado como uma atividade econômica livre, devido ao poder de concorrência dos demais modos de transportes.

A pesquisa identificou comportamentos, possivelmente ideológicos, na preferência declarada pela titularidade pública ou privada das ferrovias brasileiras, em semelhante paralelo à pesquisa de Lopes (2014), sobre financiamento de rodovias, uma vez que as opções declaradas não são explicáveis somente pelas características intrínsecas das ferrovias estudadas. Os resultados também evidenciam a queda da preferência pela ferrovia estatal e aumento do interesse pela ferrovia concessionada, mantendo-se constante a preferência pela ferrovia integralmente privada, em relação à pesquisa de Resende et al. (2009).

A pesquisa não encontrou evidências internacionais suficientes para recomendar a alteração do marco regulatório em favor da desintegração vertical e acesso aberto (open access). A comparação internacional indica que essa opção é altamente associada ao transporte de passageiros, subsidiado, cuja infraestrutura ferroviária é gerida majoritariamente por empresas ou entidades estatais. O contexto brasileiro, no entanto, recomenda a ratificação do modelo de integração vertical e desintegração geográfica, visto que o mercado brasileiro é majoritariamente de cargas, caracterizado por baixa densidade de infraestrutura e gestão privada. 
Quanto ao modo de seleção dos licitantes em eventuais processos de outorga de ferrovias, a preferência dos atores interessados entrevistados é pelo critério de menor valor de tarifa. Todavia, a evidência que se extrai do benchmarking é que a concorrência tem maior aptidão para manter preços módicos que os preços pactuados em leilões. Além disso, o tratamento da firma ferroviária como uma empresa imobiliária tem mostrado bons resultados quanto à manutenção da modicidade tarifária em substituição aos subsídios públicos, a exemplo do que pode ser observado nos EUA, Hong Kong e Japão. Assim, recomenda-se que o maior valor de outorga seja aplicado, sempre que possível.

\subsection{DESREGULAMENTAÇÃO E REPRIVATIZAÇÃO}

À luz do benchmarking dessa pesquisa foi possível observar que o desenvolvimento ferroviário é possível em termos de mercado. No modelo de integração vertical, as firmas ferroviárias são estimuladas a empreender com maior liberdade para definir traçados, tarifas e principalmente organização. O monopólio ferroviário de cargas pode ser facilmente contestado por outras firmas ferroviárias e pela modalidade rodoviária, de maneira que a intensa regulação de preços e rotas pode ser desnecessária mesmo em um contexto de operação verticalizada, a exemplo dos mercados dos Estados Unidos e Canadá.

Além disso, no Brasil, o histórico de atuação estatal conduziu o sistema ferroviário para um regime de intensa concentração oligopolista, que só poderia ser desfeito se as concessões ferroviárias ao invés de serem antecipadamente prorrogadas fossem relicitadas em novos termos, levando em consideração a possibilidade de competição intramodal. No novo modelo desregulado e reprivatizado, as outorgas poderiam ser de dois tipos: autorização, nos casos em que a futura firma ferroviária puder adquirir seus domínios sem a necessidade de desapropriações ou subsídios financeiros do Estado; e concessão, em todos os demais casos.

Diferentemente do que se tem praticado no Brasil até o presente, a outorga será em caráter de perpetuidade incondicional no caso de autorizações e condicionada no caso de concessões, sem a necessidade de "devolução" de ativos ao fim do termo do contrato de outorga.

Dessa forma, não existirão desincentivos para investimento, como atualmente ocorrem devido aos prazos dos atuais contratos de concessão. Recomenda-se que a outorga da concessão tenha um prazo fixado pelo poder concedente para o atingimento de metas de eficiência e expansão da produtividade, por exemplo, em termos de TKU e PKU. Em raras exceções seriam fixadas metas de expansão de malha, mas, no geral, o Estado não interferiria no modo em como as metas de eficiência seriam atingidas pela firma privada. Se ao termo do prazo, a firma atingir a meta, passará a gozar dos ativos em perpetuidade. Caso não alcance o objetivo 
contratado, deverá devolver os ativos recebidos no início do contrato. Imóveis e demais ativos incorporados no prazo condicional e constituídos em ramais conexos à concessão original, poderão remanescer com a firma, na forma de outorga por autorização.

Por exemplo, recomenda-se que a Ferrovia Norte Sul - Tramo Central e Sul seja concedida com cláusula de eficiência condicionada a extensão de um ramal aos portos de Vila do Conde e Belém, em um prazo sugerido de 25 anos. Caso a concessionária atinja a meta dentro do prazo, inclusive em termos de TKU e PKU previamente estabelecidos pelo poder concedente, passa a gozar em termos de perpetuidade dos ativos, não dispensado o pagamento anual da outorga contratada. Caso não atinja a meta, a ferrovia original é devolvida ao poder concedente, mas o que for construído pela concessionária entre Açailândia e os portos do Pará poderão remanescer com a firma outorgada nas mesmas condições estabelecidas para uma outorga autorizada.

No proposto novo modelo, desregulado e reprivatizado, a organização do tráfego será a mesma dominante no Brasil atualmente, i.e. a verticalização com abertura para o direito de passagem e para o tráfego mútuo, por meio de contratos voluntários, respeitado os direitos dos usuários dependentes. Outra inovação proposta é o aproveitamento dos ativos ferroviários, para exploração do transporte de cargas e passageiros associado à exploração imobiliária, como forma de financiamento do transporte.

O critério de licitação que se recomenda é o de maior valor de outorga. Neste caso, vencerá a concorrência a firma que apresentar o maior percentual de bonificação, à vista, para o poder público. O restante da bonificação será pago anualmente em sistema de perpetuidade. Se houver alienação de ativos, mobiliários ou imobiliários, o poder público será remunerado pelo mesmo percentual de bonificação pago à vista. Recomenda-se que parte de todas essas receitas sejam destinadas a um Fundo específico para financiamento do setor. Propõe-se também que a privatização das ferrovias concedidas seja feita em etapas ou ciclos, das de maior densidade de tráfego para as de menor densidade de tráfego. Havendo leilões desertos, propõe-se que, na etapa seguinte, a ferrovia seja relicitada novamente por menor valor de contrapartida pública. Não havendo novamente interessados, recomenda-se a alienação dos imóveis ou exploração pública da ferrovia, quando de relevante interesse público.

Ferrovias greenfield poderiam ser as primeiras a serem outorgadas por iniciativa das firmas ferroviárias através de Procedimentos de Manifestação de Interesses Ferroviários, regulados em marco regulatório específico.

Recomenda-se também que a União recupere o Fundo Nacional de Investimentos Ferroviários, incorporando a ele receitas advindas da CIDE combustíveis e de multas de 
trânsito, além das multas dos contratos de outorga no setor ferroviário. Os recursos do Fundo seriam destinados a recuperação da malha para o transporte de passageiros e financiamento de ramais estratégicos, sem viabilidade econômica para exploração integralmente privada.

Para tanto, o marco regulatório brasileiro precisaria ser profundamente alterado, a fim de permitir a existência da firma ferroviária integralmente privada. Nesse sentido, elaborou-se o seguinte roteiro de desregulamentação e reprivatização, contido na tabela 7.1:

Tabela 7.1 Plano de ações sugerido para recuperação da modalidade ferroviária brasileira

\begin{tabular}{|c|c|c|c|}
\hline Etapa & Objetivo & Detalhamento & Prazo \\
\hline 1 & $\begin{array}{l}\text { Desregulamentação } \\
\text { da atividade }\end{array}$ & $\begin{array}{l}\text { Alteração das Leis } \mathrm{n}^{\circ} 9.074,8.987,10.233 \text {, a fim de permitir a } \\
\text { outorga por autorização da exploração integralmente privada de } \\
\text { ramais ferroviários de carga e passageiros. }\end{array}$ & 2019 \\
\hline 2 & $\begin{array}{l}\text { Desregulamentação } \\
\text { da atividade }\end{array}$ & $\begin{array}{l}\text { Alteração das Leis } \mathrm{n}^{\circ} 9.074,8.987,10.233 \text {, a fim de permitir a } \\
\text { outorga por concessão em regime de perpetuidade da exploração } \\
\text { integralmente privada de ramais ferroviários de carga e } \\
\text { passageiros. }\end{array}$ & 2020 \\
\hline 3 & $\begin{array}{l}\text { Revitalização do } \\
\text { Fundo Nacional de } \\
\text { Investimentos } \\
\text { Ferroviários }\end{array}$ & $\begin{array}{l}\text { Alteração da legislação para financiar ramais ferroviários por meio } \\
\text { da redistribuição de Contribuições de Intervenção no Domínio } \\
\text { Econômico, multas de trânsito, e outorgas no setor. }\end{array}$ & 2020 \\
\hline 4 & $\begin{array}{l}\text { Incorporação da } \\
\text { atividade imobiliária } \\
\text { entre as } \\
\text { competências das } \\
\text { firmas ferroviárias }\end{array}$ & $\begin{array}{l}\text { Alteração da legislação para permitir às novas firmas outorgadas à } \\
\text { capacidade de atuar no mercado imobiliário em regime de livre } \\
\text { iniciativa. }\end{array}$ & 2020 \\
\hline 5 & $\begin{array}{lr}\text { Abertura de } & \text { editais } \\
\text { internacionais } & \text { de } \\
\text { Proposição } & \text { de } \\
\text { Manifestação } & \text { de } \\
\text { Interesse } & \end{array}$ & $\begin{array}{l}\text { Convocação do mercado ferroviário internacional para a outorga } \\
\text { em regime de autorização em perpetuidade de ramais ferroviários } \\
\text { planejados ou inexistentes, cujas obras de construção ainda não se } \\
\text { iniciaram, atualmente. }\end{array}$ & 2020 \\
\hline 6 & $\begin{array}{l}\text { Planejamento } \\
\text { reprivatização }\end{array}$ & $\begin{array}{l}\text { Definição dos ramais que serão relicitados em separado. Priorizar- } \\
\text { se-á a competição intramodal evitando-se a formação de bacias } \\
\text { geográficas e a aglutinação de rotas paralelas. }\end{array}$ & 2023 \\
\hline 7 & $\begin{array}{l}\text { Leilões de } \\
\text { privatização integral }\end{array}$ & $\begin{array}{l}\text { Relicitar todos os ramais licitados em 1995/96, na forma mais } \\
\text { desconcentrada quanto possível. }\end{array}$ & 2025 \\
\hline
\end{tabular}

\subsection{PROPOSTA DE EXPLORAÇÃO}

Além disso, esta pesquisa avalia a percepção dos stakeholders brasileiros a novas maneiras de exploração do mercado ferroviário, a fim de comprovar a conclusão de Takasaki (2014), de 
que a melhor opção de exploração ferroviária não envolve a escolha de um único modelo, pois, cada caso pode levar a um modelo diferente. Assim, o trabalho procurou comprovar a hipótese de que ferrovias devem ser exploradas e reguladas, diferentemente, em função do grau de competitividade que possuem.

Foi possível observar que os atores interessados que responderam esta pesquisa não atribuem as 10 ferrovias estudadas características distintas suficientes para justificar a adoção de modelos diferentes quanto à propriedade da ferrovia, à organização do tráfego, ao modelo de licitação da concessão e à bitola de operação. Há duas explicações para esse comportamento. A primeira é que, de fato, as ferrovias não possuem características intrínsecas diferentes que justifiquem um ou outro modelo. Os respondentes são indiferentes às ferrovias no momento de declarar alguma preferência, que só poderá ser explicada por motivações alheias aos parâmetros do estudo.

A segunda explicação é que os efeitos das diferenças para essas quatro características são demasiadamente pequenos de maneira que o tamanho da amostra foi insuficiente para revelar as diferenças entre as ferrovias.

A tabela 7.2 expõe os resultados dos entrevistados, confrontados com a resposta recomendada por este estudo, segundo a interpretação das teorias de Russel Pittman e Chris Nash: 


\begin{tabular}{|c|c|c|c|c|c|c|c|c|c|c|c|c|c|c|c|c|c|c|}
\hline 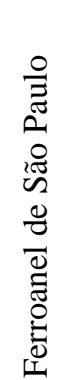 & 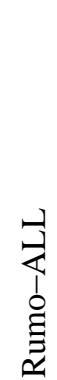 & 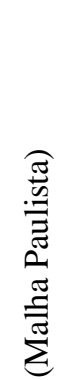 & $\stackrel{\tilde{n}}{\tilde{\Sigma}}$ & 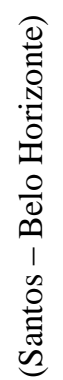 & $\frac{n}{\frac{n}{Z}}$ & 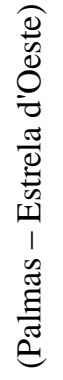 & 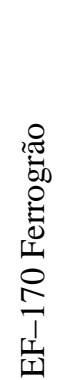 & 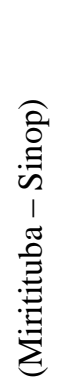 & 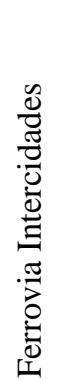 & 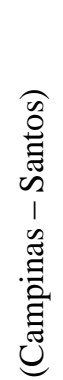 & 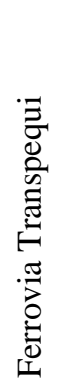 & 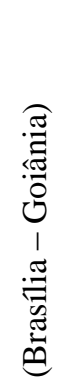 & 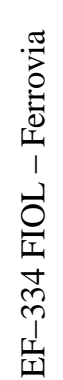 & 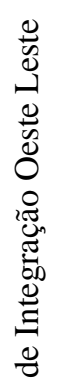 & 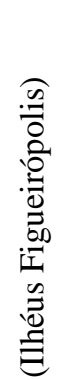 & 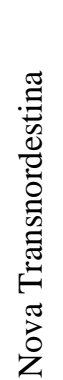 & 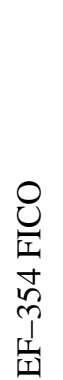 & 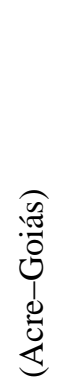 \\
\hline
\end{tabular}

\begin{tabular}{|c|c|c|c|c|c|c|c|c|c|c|}
\hline \multicolumn{11}{|l|}{ Propriedade } \\
\hline Moda (Atores) & & & & & Con & & & & & \\
\hline $\begin{array}{r}\text { Frequência da } \\
\text { moda }\end{array}$ & $58 \%$ & $74 \%$ & $68 \%$ & $73 \%$ & $59 \%$ & $59 \%$ & $56 \%$ & $71 \%$ & $65 \%$ & $70 \%$ \\
\hline Recomendação & \multicolumn{10}{|c|}{ Integralmente Privado } \\
\hline $\begin{array}{l}\text { Frequência da } \\
\text { Recomendação }\end{array}$ & $32 \%$ & $21 \%$ & $26 \%$ & $16 \%$ & $35 \%$ & $30 \%$ & $36 \%$ & $21 \%$ & $21 \%$ & $21 \%$ \\
\hline \multicolumn{11}{|l|}{ Exploração } \\
\hline Moda (Atores) & \multicolumn{10}{|c|}{ Vertical compartilhada (direito de passagem e tráfego mútuo) } \\
\hline $\begin{array}{r}\text { Frequência da } \\
\text { moda }\end{array}$ & $49 \%$ & $53 \%$ & $58 \%$ & $53 \%$ & $50 \%$ & $53 \%$ & $50 \%$ & $57 \%$ & $53 \%$ & $54 \%$ \\
\hline Recomendação & \multicolumn{10}{|c|}{ Vertical compartilhada (direito de passagem e tráfego mútuo) } \\
\hline $\begin{array}{r}\text { Frequência da } \\
\text { Recomendação }\end{array}$ & $49 \%$ & $53 \%$ & $58 \%$ & $53 \%$ & $50 \%$ & $53 \%$ & $50 \%$ & $57 \%$ & $53 \%$ & $54 \%$ \\
\hline \multicolumn{11}{|l|}{ Outorga } \\
\hline Moda (Atores) & \multicolumn{10}{|c|}{ Menor valor de tarifa } \\
\hline $\begin{array}{r}\text { Frequência da } \\
\text { moda }\end{array}$ & $43 \%$ & $40 \%$ & $35 \%$ & $38 \%$ & $32 \%$ & $47 \%$ & $49 \%$ & $41 \%$ & $34 \%$ & $42 \%$ \\
\hline Recomendação & \multicolumn{10}{|c|}{ Maior valor de outorga } \\
\hline $\begin{array}{l}\text { Frequência da } \\
\text { Recomendação }\end{array}$ & $15 \%$ & $26 \%$ & $26 \%$ & $25 \%$ & $22 \%$ & $24 \%$ & $24 \%$ & $27 \%$ & $27 \%$ & $24 \%$ \\
\hline
\end{tabular}


Nota-se que os atores interessados atualmente já preferem a integração vertical como forma de organização das firmas. No entanto, a preferência declarada dominante para os critérios de escolha do vencedor e titularidade da firma é a de menor custo para o usuário, em convergência com a teoria do efeito carona (Varian, 1947). Em razão dos efeitos negativos dessas estratégias, recomenda-se a adoção da outorga pelo maior valor e a titularidade integralmente privada, atualmente, inexistente no Brasil.

\subsection{LIMITAÇÕES DO ESTUDO}

As maiores limitações do estudo dizem respeito ao tamanho das amostras, insuficientes para obtenção de resultados estatisticamente significativos em regressões múltiplas ou logística. As análises do benchmark poderiam ter resultados mais robustos se aplicada uma análise multe temporal, pois, historicamente, a extensão das malhas apresentou comportamentos variados que não foram capturados na análise estática do relatório de WEF (2017). Por exemplo, o significativo desenvolvimento da China é característico das últimas duas décadas, enquanto na Europa, não há aumento significativo da malha nas últimas duas décadas. Possivelmente uma regressão em painel com mais países em um horizonte temporal maior dariam maior robustez a recomendação pelo modelo de integração vertical.

\subsection{RECOMENDAÇÕES PARA TRABALHOS FUTUROS}

Quanto ao benchmarking internacional, recomenda-se analisar além da evolução temporal dos mercados a influência dos subsídios estatais, do PIB e do tamanho da população no desempenho das infraestruturas ferroviárias. A pesquisa evidenciou que todos os modelos são aptos a obtenção de resultados de qualidade, a diferença primordial para a os interesses da sociedade, parece ser o montante de subsídios gastos em cada modelo. Assim, recomenda-se comparar em trabalhos futuros os subsídios aplicados entre os diversos modelos e países.

Quanto a opinião dos atores interessados, recomenda-se a reformulação do questionário a fim de focar nas variáveis mais relevantes observadas nesta pesquisa exploratória e ampliação da amostra. Um maior envolvimento institucional de órgão tradicional de pesquisa poderia contribuir nesse sentido. Em paralelo pode ser empreendido esforço para delinear o perfil da população e ajustar a amostragem para aumentar essa representatividade. Um melhor planejamento da pesquisa pode levar a uma melhoria dos resultados sem a necessidade de um acréscimo muito grande ou mesmo inviável da amostra de dados.

Sugere-se, ainda como recomendação para trabalhos futuros, a avaliação de causa e efeito dos riscos na implantação de novos serviços de transporte ferroviários aplicando-se técnicas de análise de árvore de falha, análise de eventos e análise de modos e efeitos de falhas em conjunto. 


\section{REFERÊNCIAS BIBLIOGRÁFICAS}

AAR (2016) Association of American Railroads. Types of Railroads. Disponível em: https://www.aar.org/todays-railroads/our-network?t=typesofrailroads

AAR (2017) Association of American Railroads. America's Freight Railroads Under Balanced Regulation. Disponível em: https://www.aar.org/BackgroundPapers/America's\%20Freight\%20Railroads\%20Under \%20Balanced\%20Regulation.pdf

ACIOLI, R. G. (2007) Os Mecanismos de Financiamento das Ferrovias Brasileiras. Dissertação de Mestrado. Universidade Federal do Rio de Janeiro.

ACWORTH, W. M. (1923). Grouping under the Railways Act, 1921. The Economic Journal, 33(129), 19-38.

ANTF (2014a) Associação Nacional dos Transportadores Ferroviários. As ferrovias nos trilhos do desenvolvimento. Brasília. Disponível em: http://www.antf.org.br/images/stories/material-institucional/documento-dospresidenciaveis-ago2014.pdf.

ANTF (2014b) Associação Nacional dos Transportadores Ferroviários. Balanço do Transporte Ferroviário de Cargas no Brasil de 2013. Brasília. Disponível em: http://www.antf.org.br/images/2015/pdfs/palestra-2014-antf-balanco-do-transporteferroviario-de-2013-versao-gustavo-30-09-14.pdf

ANTF (2015) Associação Nacional dos Transportadores Ferroviários. Balanço do Transporte Ferroviário de Cargas 2014. Brasília. Disponível em: http://www.antf.org.br/images/2015/informacoes-do-setor/numeros/balanco-dotransporte-ferroviario-de-2014-v130815.pdf

ANTF (2017) Associação Nacional dos Transportadores Ferroviários. Mapa das Concessionárias Associadas da ANTF. Disponível em: http://www.antf.org.br/wpcontent/uploads/2016/12/mapa1.pdf acessado em 26, nov. 2017.

ANTT (2015) Agência Nacional de Transportes Terrestres. Ferrovias - PIL Segunda Etapa. Disponível em: http://pilferrovias.antt.gov.br Acessado em 2 de dez. 2017.

ANTT (2016a) Agência Nacional de Transportes Terrestres. Disponível em: http://www.antt.gov.br/index.php/content/view/4751/Ferroviaria.html.

ANTT (2016b) Agência Nacional de Transportes Terrestres. Ouvidoria. Mensagem eletrônica.

ANTT (2017) Agência Nacional de Transportes Terrestres. Declaração de Rede. Disponível em: http://www.antt.gov.br/ferrovias/Declaracao_de_Rede.html Acessado em 4 de 12, de 2017.

ANUT (2011) Associação Nacional dos Usuários do Transporte de Carga. Transporte e Logística no Brasil - Visão do Setor Privado. Seminário sobre transporte e logística. Brasília.

AR (2017) American-Rails. Railroad History, An Overview Of The Past. Disponível em: http://www.american-rails.com/railroad-history.html 
ARAÚJO, D. (1986) Bitola métrica ou larga: um estudo do ponto de vista econômico das ferrovias. Centro-Oeste, São Paulo, $\mathrm{n}^{\circ}$ 15, abril-maio 1986. Disponível em: http://vfco.brazilia.jor.br/ferrovias/bitolas/15bitMetricaOuLarga.htm. Acesso em: 26 nov. 2017.

AZEREDO, M. C. R. de (2014) Trem de alta velocidade RJ-SP: estudo de caso sobre sua não implementação durante os governos Lula e Dilma. Dissertação de Mestrado. Escola Brasileira de Administração Pública. Fundação Getúlio Vargas. Rio de Janeiro, 75p.

BAUMOL, W. J., PANZAR, J. C., \& WILLIG, R. D. (1983). Contestable markets: An uprising in the theory of industry structure: Reply. The American Economic Review, 73(3), 491-496. Disponível em: http://www.jstor.org/stable/pdf/1808145.pdf

BARbOSA, N., CARDOSO, J. E., KASSAB, G. \& OCCHI, G. M. (2015) Exposição de Motivos Interministerial $n^{\circ}$ 212/2015/MP/MJ/MCidades/MI. 4 de dez. 2015. BrasíliaDF. Disponível em: http://www.planalto.gov.br/ccivil_03/_ato20152018/2015/Exm/Exm-MP-700-15.pdf

BENINI, R. A. C. B. (2012). Avaliação econômico-financeira das concessionárias de ferrovia no Brasil : uma análise de precificação de frete. Dissertação de Mestrado. Universidade de São Paulo. Piracicaba, SP.

BITTENCOURT, F. M. R. (2009) Investimento Público Federal em Infra-Estruturas de Transportes em Regime de Concessão - Subsídios para o Desenho de Políticas. Texto Para Discussão no 60. Brasília, DF, xxp.

BLANNING, T. CW. (2007) The pursuit of glory: Europe, 1648-1815. Penguin.

BNSF (2017) BNSF Railway. Disponível em: https://www.bnsf.com/ Acessado em 2 de dez. 2017.

BOGART, D. (2010). A global perspective on railway inefficiency and the rise of state ownership, 1880-1912. Explorations in Economic History, 47(2), 158-178.

BOGART, D., \& CHAUDHARY, L. (2015). Off the rails: Is state ownership bad for productivity?. Journal of Comparative Economics, 43(4), 997-1013.

BORGES, A. (2016). País investe só 0,6\% do PIB em transporte. O Estado de São Paulo. Caderno E\&N. 02 de jul. 2016.

BORGES, R. \& OLIVEIRA, F. (2005) Setor Ferroviário Brasileiro. Brasília.

BRASIL (2007) Ministério dos Transportes \& Ministério da Defesa. Plano Nacional de Logística e Transportes - Relatório Executivo.

BRASIL (2017) Ministério dos Transportes, Portos e Aviação Civil \& Empresa de Planejamento e Logística. Anuário Estatístico de Transportes 2010 - 2016. Brasília, DF, 56p. disponível

em: http://www.transportes.gov.br/images/2017/Sum\%C3\%A1rio_Executivo_AET_2010__2016.pdf.

BRAY, D., \& SAYEG, P. (2013). Private sector involvement in urban rail: Experience and lessons from South East Asia. Research in Transportation Economics, 39(1), 191-201. 
BRIGHTLINE (2017) Brightline. Disponível em: https://gobrightline.com Acessado em: 2 de dez. 2017.

BUNDESNETZAGENTUR (2016) Market Analysis Railway 2016. Bundesnetzagentur für Elektrizität, Gas, Telekommunikation, Post und Eisenbahnen. Bonn. Disponível em: https://www.bundesnetzagentur.de/SharedDocs/Downloads/EN/Areas/Rail/Downloads/ MarketAnalysisRailway2016.pdf?_blob=publicationFile\&v=3 Acessado em: 29, nov. 2017.

CAMPOS, J. (2001). Lessons from railway reforms in Brazil and Mexico. Transport Policy, 8(2), 85-95.

CAMPOS NETO, C. A. da S., PÊGO FILHO, B., ROMMINGER, A. E., FERREIRA, I. M. \& VASCONCELOS, L. F. S. (2010) Gargalos e demandas da infraestrutura ferroviária e os investimentos do PAC: mapeamento Ipea de obras ferroviárias. Texto para Discussão $\mathrm{n}^{\circ}$ 1465. Rio de Janeiro.

CAO, J., LIU, X. C., WANG, Y., \& LI, Q. (2013). Accessibility impacts of China's highspeed rail network. Journal of Transport Geography, 28, 12-21.

CARNEIRO, J. M. (2011). Modelo de Previsão de Insolvência de Concessionárias de Ferrovias no Brasil. Dissertação de Mestrado, Publicação T.DM-004A/2011, Departamento de Engenharia Civil e Ambiental, Faculdade de Tecnologia, Universidade de Brasília, DF, 76 p.

CASTRO, N. de. (2002). Estrutura, desempenho e perspectivas do transporte ferroviário de carga. Pesquisa e Planejamento Econômico, 32(2), 251-283.

CAVALCANTI, B. S. (2002) Reformas e políticas regulatórias na área de transportes. In VII Congreso Internacional del CLAD sobre la Reforma del Estado y de la Administración Pública (pp. 8-11).

CAVALCANTI, F. R. (2010) Evolução histórica da malha ferroviária brasileira - extensão dos trilhos e variação anual.

CHRYSLER CORPORATION, FORD MOTOR COMPANY \& GENERAL MOTORS CORPORATION (1993). Potencial Failure Mode and Effects Analysis (FMEA) Reference Manual.

CIA (2017) Central Intelligence Agency. The World Factbook. Disponível em: https://www.cia.gov/library/publications/the-world-factbook/rankorder/2121rank.html

CNT (2013) Confederação Nacional do Transporte. O sistema ferroviário brasileiro. Brasília.

CNT (2014) Confederação Nacional do Transporte. Matriz do Transporte de Cargas. CNT Transporte Atual. Brasília-DF. Ano XIX, 220, p. 73. Disponível em: http://cms.cnt.org.br/Imagens\%20CNT/Revista\%20CNT/2014/REVISTA\%20CNT\%20 220\%20FINAL.pdf

CNT (2015) Confederação Nacional do Transporte. Pesquisa CNT de Ferrovias 2015. Brasília, 234 p. http://www.cnt.org.br/Pesquisa/pesquisa-cnt-ferrovias.

COSAN (2016) Cosan. Disponível em: http://54.232.116.169/pt-br/quem-somos . 
COSTA, M. T. (2017) Temer dá aval para projeto de Trem Intercidades. Correio Popular, Campinas, 28 de mar. 2017.

CREEC (2016) China Railway Eryuan Engineering Group CO. LTD. Company Profile. Disponível em: http://www.creegc.com/en/tabid/173/Default.aspx

CSN (2017) Companhia Siderúrgica Nacional. Transnordestina Logística SA. Disponível em: http://www.tlsa.com.br/conteudo_pti.asp?idioma $=0 \&$ conta $=45 \&$ tipo $=59542 \& \mathrm{prSv}=1$

CUI, S., \& BESANKO, D. (2016). Horizontal versus vertical separation in railway networks : Implications for network quality. Economics Letters, 138, 78-80. https://doi.org/10.1016/j.econlet.2015.12.001

CURRIE, G., \& DE GRUYTER, C. (2016). Exploring performance outcomes and regulatory contexts of Light Rail in Australia and the US. Research in Transportation Economics, 59, 297-303.

CURY, M. V. Q. (2011) Escolha entre a Bitola Larga Brasileira e a Bitola Internacional Padrão para a Linha 4 do Metrô do Rio de Janeiro. Nota Técnica. Rio de Janeiro.

DAlBEM, M. C., BRANDÃO, L., \& MACEDO-SOARES, T. D. L. V. A. De. (2010). Avaliação econômica de projetos de transporte: melhores práticas e recomendações para o Brasil. Revista de Administração Pública, 44(1), 87-117. http://doi.org/10.1590/S0034-76122010000100005

DAYCHOUM, M. T., \& SAMPAIO, P. R. P. (2017). Regulação e concorrência no setor ferroviário.

DB (2017) Deutschebahn Facts and figures 2016. Disponível em: http://www.deutschebahn.com/en/group/ataglance/facts_figures.html Acessado em: 2 de dez. 2017.

DE CAMARGO CAVALCANTI, R. (2015) Acordos em controle de concentrações e o instituto da arbitragem. Revista de Defesa da Concorrência, v. 3, n. 2, 2015.

DESMARIS, C. (2014). The reform of passenger rail in Switzerland: more performance without competition. Research in Transportation Economics, 48, 290-297.

DRAGUTESCU, A. E. (2006) A different perspective of planning: transit-oriented development. Tese de Doutorado. Universidade do Porto. Porto, Portugal.

DURÇO, F. F. (2011) A regulação do setor ferroviário brasileiro: monopólio natural, concorrência e risco moral. Dissertação de Mestrado. Escola de Economia de São Paulo. Fundação Getúlio Vargas. São Paulo, SP, 111p.

EB (2017a) $1{ }^{\circ}$ Batalhão Ferroviário do Exército Brasileiro. Disponível em: http://www.2bfv.eb.mil.br

EB (2017b) 1 o Batalhão Ferroviário do Exército Brasileiro. Disponível em: http://www.1bfv.eb.mil.br

ELLER, R. D. A. G., SOUSA JUNIOR, W. C. de, \& CURI, M. L. C. (2011). Custos do transporte de carga no Brasil: rodoviário versus ferroviário. Journal of Transport Literature, 5(1), 50-64. 
EPL (2016) Empresa de Planejamento e Logística S.A. Transporte inter-regional de carga no Brasil - Panorama 2015. http://www.epl.gov.br/transporte-inter-regional-de-cargano-brasil-panorama-2015.

FECI (2017) Florida East Cost Industries. Disponível em http://www.feci.com Acessado em: 2 de dez. 2017.

FELIX, M. K. R. \& CAVALCANTE FILHO, J. T. (2016). Marco Normativo do Setor Ferroviário Brasileiro: Caminhos para Superação da Insegurança Jurídica e Regulatória. Brasília: Núcleo de Estudos e Pesquisas/CONLEG/Senado, Dezembro/2016 (Texto para Discussão $\mathrm{n}^{\circ}$ 218). Disponível em: www.senado.leg.br/estudos. Acesso em 12 de dezembro de 2016.

FIELD, A. (2009). Descobrindo a estatística usando o SPSS. 2. ed. Porto Alegre. Artmed. $688 \mathrm{p}$.

FINGER, M. (2014). Governance of competition and performance in European railways: An analysis of five cases. Utilities Policy, 31, 278-288.

FRA (2014) Federal Railroad Administration. Summary of Class II and Class III Railroad Capital Needs and Funding Sources. Disponível em: http://www.infrastructurereportcard.org/wp-content/uploads/2017/05/C1-140212001_D1-FRA-Report-on-RRs-Report-9-30.pdf

FRIEBEL, G., IVALDI, M., \& VIBES, C. (2004). Railway (De) Regulation: A European Efficiency Comparison. Centre for Economic Policy Research. London, UK.

FRIEBEL, G., GURIEV, S., PITTMAN, R., SHEVYAKHOVA, E. \& TOMOVA, A. (2007). Railroad restructuring in Russia and Central and Eastern Europe: one solution for all problems?. Transport Reviews, 27(3), 251-271.

FRIEDMAN, M., \& FRIEDMAN, R. (2015). Livre para escolher: um depoimento pessoal. Rio de Janeiro: Record.

FRISCHTAK, C. (2013). Infraestrutura e desenvolvimento no Brasil. In: F. Veloso, Ferreira, P. C., Giambiagi, F. e S. Pessôa (Org.). Desenvolvimento econômico: uma perspectiva brasileira. Rio de Janeiro: Campus.

FDA (2014) Federal Railroad Administration. Summary of Class II and Class III Railroad Capital Needs and Funding Sources. Washington, USA.

GALVÃO, O. J. A. (1996). Desenvolvimento dos transportes e integração regional no Brasil — Uma perspectiva histórica. Planejamento e Políticas Públicas-IPEA, 183-214.

GÓMEZ-IBÁÑEZ, J. A. (2016). Open Access to Infrastructure Networks: The Experience of Railroads. Review of Industrial Organization, 49(2), 311-345. https://doi.org/10.1007/s11151-016-9527-y

GRODINSKY, J. (2000). Transcontinental railway strategy, 1869-1893: a study of businessmen. Beard Books.

GUERRA, P. H. G. (2014) O PAC e o Setor de Ferrovias: do Incrementalismo à Proposta de um Novo Paradigma. Dissertação de Mestrado. Escola de Administração de Empresas de São Paulo. Fundação Getúlio Vargas. São Paulo, SP, 121p. 
IGR-Rail (2017) Independent Regulators' Group - Rail. Fifth Annual Market Monitoring Report.

INDIAN RAILWAYS (2017) Statistical Summary. Disponível em: http://www.indianrailways.gov.in/railwayboard/uploads/directorate/stat_econ/IRSP_201 5-16/Summary\%20Sheet_Eng_pdf_pdf.pdf

IPEA (2010) Infraestrutura econômica no Brasil: diagnósticos e perspectivas para 2025. Brasília, IPEA, 2010.

JIAO, J., WANG, J., JIN, F., \& DUNFORD, M. (2014). Impacts on accessibility of China's present and future HSR network. Journal of Transport Geography, 40, 123-132.

JUPE, R., \& CROMPTON, G. (2006). "A deficient performance": The regulation of the train operating companies in Britain's privatised railway system. Critical perspectives on accounting, 17(8), 1035-1065.

JUPE, R. (2009). A "fresh start" or the "worst of all worlds"? A critical financial analysis of the performance and regulation of Network Rail in Britain's privatised railway system. Critical Perspectives on Accounting, 20(2), 175-204.

JUSTEN FILHO, M. (1998). Empresa, ordem econômica e constituição. Revista de Direito Administrativo, 212, 109-133.

KEIO (2017) Keio Corporation Profile. Disponível em: https://www.keio.co.jp/english/corporate/profile.html Acessado em 2 de dez. 2017

KENTON, M. M., \& GIFFORD, J. (2015). Comparing Financing Models for US Intercity Passenger Rail Development. Disponível em: http://malcolmkenton.info/wpcontent/uploads/2017/08/Kenton_PUBP-714_TermPaper.pdf Acessado em 2 de dez. 2017.

KÜSTER, G. B. (2013) A expansão do grupo ALL - América Latina Logística S.A. Dissertação de Mestrado - Universidade Federal do Paraná, Setor de Ciências Sociais Aplicadas, Programa de Pós-graduação em Desenvolvimento Econômico. Curitiba, PR, $119 \mathrm{p}$.

LANG, A. E. (2007) As Ferrovias no Brasil e Avaliação Econômica de Projetos: uma Aplicação em Projetos. Dissertação de Mestrado em Transportes, Publicação T.DM002A/2007, Departamento de Engenharia Civil e Ambiental, Universidade de Brasília, Brasília, DF, 154p.

LAURINO, A., RAMELLA, F. \& BERIA, P. (2015) The economic regulation of railway networks : A worldwide survey. Transportation Research Part A, 77, 202-212. 2015. Disponível em: http://doi.org/10.1016/j.tra.2015.04.011

LEAN, H. H., HUANG, W., \& HONG, J. (2014). Logistics and economic development: Experience from China. Transport Policy, 32, 96-104.

LI, Z., \& XU, H. (2016). High-Speed Railroad and Economic Geography: Evidence from Japan. ADB Economics Working Paper Series, 48.

LODGE, M., VAN STOLK, C., BATISTELLA-MACHADO, J., HAFNER, M., SCHWEPPENSTEDDE, D. \& STEPANEK, M. (2017) Regulação da infraestrutura 
logística no Brasil. London School of Economics and Political Science. Londres, Inglaterra.

LOPES, A. D. O. (2014). Identificação de fatores de influência na aceitação de tarifas de pedágio rodoviário: um estudo de caso entre as cidades de Brasília e Goiânia. Dissertação de Mestrado em Transportes, Publicação T.DM-012A/2014, Departamento de Engenharia Civil e Ambiental, Universidade de Brasília, Brasília, DF, 189p.

LUDVIGSEN, J., \& OSLAND, O. (2009). Liberalisation of rail freight markets in the old and new EU-member states. European Journal of Transport and Infrastructure Research EJTIR, 1(9).

MACAMBIRA FILHO, J. K. D. (2014). Mensuração de eficiência produtiva das ferrovias brasileiras de carga: uma aplicação de modelos DEA e Tobit. Dissertação de Mestrado em Transportes, Publicação T.DM-016A/14, Departamento de Engenharia Civil e Ambiental, Universidade de Brasília, Brasília, DF, 97p.

MÄKITALO, M. (2011). Why Do Open Rail Freight Markets Fail to Attract Competition? Analysis on Finnish Transport Policy S, 11(11), 1-19.

MARCHETTI, D., \& WANKE, P. (2016). Brazil's rail freight transport: Efficiency analysis using two-stage DEA and cluster-driven public policies. Socio-Economic Planning Sciences.

MARQUES, S. de A. (1996). Privatização do Sistema Ferroviário Brasileiro. Texto Para Discussão No 434. IPEA. Brasília, DF.

MENDES, M. (2011a) Por que o governo deve interferir na economia? Brasil Economia e Governo, Brasília. 24 de mar. 2011

MENDES, M. (2011b) Por que a intervenção do governo pode gerar prejuízos à sociedade? Brasil Economia e Governo, Brasília. 5 de mai. 2011

MENDES, M. (2015) Por que o Brasil cresce pouco? desigualdade, democracia e baixo crescimento no país do futuro. Elsevier.

MERKERT, R. \& HENSHER, D. A. (2014) Open access for railways and transaction cost economics-Management perspectives of Australia's rail companies. Research in Transportation Economics, v. 48, pp. 227-236.

MIRANDA E SILVA, B. F. (2013). Os Desafios do Investimento em Infraestrutura no Brasil : A Questão do Financiamento. Revista Paradigma, XVIII, 141-162.

MIZUTANI, F., \& URANISHI, S. (2013). Does vertical separation reduce cost? An empirical analysis of the rail industry in European and East Asian OECD Countries. Journal of Regulatory Economics, 43(1), 31.

MIZUTANI, F., SMITH, A., NASH, C., \& URANISHI, S. (2014). Comparing the Costs of Vertical Separation, Integration, and Intermediate Organisational Structures in European and East Asian Railways (Discussion Paper Series Nº 2014-37). Kobe, Japan. 41p. 
MORAIS, A. C de. (2012). Projetos de Infraestrutura de Transportes: Inserção Efetiva na Agenda Governamental. T.TD-005A/2012, Departamento de Engenharia Civil e Ambiental, Faculdade de Tecnologia, Universidade de Brasília, Brasília, 111p.

MORAES, A. F. B. L. A. (2017). Critérios de avaliação de informação na regulação de transporte terrestre no Brasil. Publicação T.DM-006/2017, Departamento de Engenharia Civil e Ambiental, Faculdade de Tecnologia, Universidade de Brasília, Brasília, 99p.

MOURA, C. (2000). Análise de Modo e Efeitos de Falha Potencial (FMEA): Manual de Referência. SAE J-1739.

MT (2012) Ministério dos Transportes. Plano Nacional de Logística e Transportes - Relatório Final. Brasília-DF. Disponível em: http://www.transportes.gov.br/images/2014/11/PNLT/2011.pdf

MU, R., de JONG, M., MA, Y., \& XI, B. (2015). Trading off public values in High-Speed Rail development in China. Journal of Transport Geography, 43, 66-77.

MÜLLER, A., \& ARAGONÉS, V. (2013). Details of a similar aspiration: Privatized railroad in Argentina, deregulated railroad in the USA. Research in Transportation Business \& Management, 6, 51-61.

NAKAMOTO, B. S. (UNESP). (2012). Planejamento e impasses na implementação do Trem de Alta Velocidade (TAV) entre Campinas/SP, São Paulo/SP e Rio de Janeiro/RJ. Dissertação de Mestrado. Unesp, xxx SP

NASH, C., NILSSON, JE. \& LINK, H. (2013) Comparing three models for introduction of competition into railways. Journal of Transport Economics and Policy, 47, 2

NASH, C. A. \& TORNER, J.P. (1998) Railways: Structure, Regulation and Competition Policy. OECD. Paris, 264p.

NBS (2017) National Bureau of Statistics of China. Disponível em http://data.stats.gov.cn/english/tablequery.htm?code=ACOL Acessado em 29, nov. 2017.

NETO, C. A. D. S. C., Filho, B. P., VASCONCElOS, A. E. R., FERREIRA, I. M., \& SOARES, L. F. (2010). Infraestrutura Ferroviária e os Investimentos do PAC. Secretaria de Assuntos Estratégicos da Presidência da República, 46.

NEVES, H., DUTRA, F., AFONSO, L., \& NÚÑ̃Z, A. (2005). Avaliação financeira dos mecanismos de concessão com prazo variável. Transportes, XIII, 39-47.

NUNES, I. (2006) Ferrovia brasileira: concessão pública para uso privado. Revista Gerenciais, São Paulo, v. 5, n. 2, pp. 109-119. http://www.redalyc.org/articulo.oa?id=331227108012

OLIVEIRA, F. L. de, MATOS, F. F. \& ROSA, V. H. da S. (2011) Publicidade do processo decisório: A experiência da Agência Nacional de Energia Elétrica-ANEEL. IV Congresso de Gestão Pública. Brasília, DF.

ORAIR, R. O. (2016) Condicionantes à execução do Investimento Público: relações com Regime Fiscal e Ciclo Econômico. 
OTTA, L. A. (2017) Ferroanel Norte pode virar moeda de troca. O Estado de São Paulo, São Paulo, 17 de jun. 2017.

OTTA, L. A. \& BORGES, A. (2017) Governo quer antecipar a renovação de 5 concessões ferroviárias neste ano. O Estado de São Paulo, São Paulo, 26 de fev. 2017.

PALERMO, B. B. (2015). Avaliação de concessões ferroviárias dentro do novo marco regulatório brasileiro. Dissertação de Mestrado. Fundação Getúlio Vargas. Rio de Janeiro, RJ, 57p.

PECI, A. (2002) Modelos regulatórios na área de transportes: a experiência americana. In: Congresso Internacional del Clad Sobre la Reforma del Estado y de la Administración Pública, $8^{\circ}$, Buenos Aires.

PEIXOTO, N. E. S; Felix, M. K. R \& Rocha, C. H. (2017) Análise bibliométrica por meio do H-index - Aplicação à busca por referências sobre financiamento do sistema ferroviário. XXXI Congresso Nacional de Pesquisa em Transporte da ANPET. Recife, 29 de outubro a 01 de novembro de 2017.

PEIXOTO FILHO, A. P. (2016) Análise dos Programas de Investimentos no Transporte Ferroviário de Cargas: PPA'S 2008/2011 - 2012/2015. Dissertação de Mestrado em Transportes, Publicação T.DM - 021/2016, Departamento de Engenharia Civil e Ambiental, Universidade de Brasília, Brasília, DF, 102 p.

PELEGI, A (2017) Grupo coreano se interessa por projeto de trem de passageiros entre Brasília e Goiânia. Diário do Transporte Disponível em: https://diariodotransporte.com.br/2017/05/15/grupo-coreano-se-interessa-por-projetode-trem-de-passageiros-entre-brasilia-e-goiania/

PEREIRA, A. C., SILVEIRA NETO, O. (2012). Viabilidade econômica de projetos e aspectos particulares em empreendimentos tipo projeto finance aplicados a investimentos em infraestrutura de transportes, Holos, 6(2012), 203-219.

PEREIRA, M. A., SILVA, F., \& LUNKES, R. J. (2015). Análise da eficiência ferroviária no Brasil nos anos entre 2009 a 2013. Transportes, 2, 56-63. http://doi.org/10.14295/transportes.v23i3.909.A

PIL (2012) Programa de Investimento em Logística - Rodovias e Ferrovias. Disponível em: http://www.pac.gov.br/pub/up/relatorio/601553fda730f7f943dbeea51cadd538.pdf

Acessado em 2 de dez. 2017.

PITTMAN, R. (2004) Chinese railway reform and competition: lessons from the experience in other countries. Journal of Transport Economics and Policy (JTEP), v. 38, n. 2, p. 309-332, 2004.

PITTMAN, R. (2011). Risk-averse restructuring of freight railways in China. Utilities Policy, 19(3), 152-160.

PITTMAN, R. (2013). The freight railways of the former Soviet Union, twenty years on: Reforms lose steam. Research in Transportation Business \& Management, 6, 99-115.

PNV (2017) Plano Nacional de Viação. Rede Ferroviária Federal (2016). Disponível em: https://www.transportes.gov.br/images/bit/Tabelas_Anu\%C3\%A1rio_Estat\%C3\%ADsti co_de_Transportes/03_Infraestrutura/02_Ferro/3.2.1.pdf 
POMPERMAYER, F. M., CAMPOS NETO, C. A. S. \& SOUSA, R. A. F. (2012) Nota Técnica n. 06. Considerações sobre os marcos regulatórios do setor ferroviário brasileiro-1997-2012. Brasília, 2012.

POMPERMAYER, F. M., \& da SILVA FILHO, E. B. (2016). Concessões no setor de infraestrutura: propostas para um novo modelo de financiamento e compartilhamento de riscos (No. 2177). Texto para Discussão, Instituto de Pesquisa Econômica Aplicada (IPEA).

POMPERMAYER, F. M. (2016) Aspectos regulatórios das ferrovias. Apresentação.

PPI (2017) Programa de Parcerias de Investimento. Projeto Crescer. Disponível em: http://www.projetocrescer.gov.br

PUFFERT, D. J. (2002). Path dependence in spatial networks: the standardization of railway track gauge. Explorations in Economic History, 39(3), 282-314.

RESENDE, P. T. V. De, OLIVEIRA, M. P. V. De, \& SOUSA, P. R. De. (2009). Análise do Modelo de Concessão no Transporte Ferroviário Brasileiro: a Visão dos Usuários. Revista ADM.MADE, 13(3), 40-59.

RESOR, R. R., \& LAIRD, P. G. (2013). Railroad privatization and deregulation: Lessons from three decades of experience worldwide. Research in Transportation Business \& Management. http://dx.doi.org/10.1016/j.rtbm.2012.12.007

REVISTA FERROVIÁRIA (2015) Revista Ferroviária. Dez 2014/Jan 2015.

REVISTA FERROVIÁRIA (2017) Deliberação No 124-2011/ANTT. Disponível em: http://www.revistaferroviaria.com.br/upload/Malha\%20Abandonada.pdf

RIO TINTO (2017) Rio Tinto Australia Rail. Disponível em: http://www.riotinto.com/australia/pilbara/rail-9752.aspx Acessado em: 2 de dez. 2017

RYDER, A. (2012). High speed rail. Journal of Transport Geography, 22, 303-305. https://doi.org/10.1016/j.jtrangeo.2012.03.004

RUMO (2016) Rumo Logística. Disponível em: http://pt.rumolog.com/

RZD (2017) Russian Railways. Disponível em: http://eng.rzd.ru/

SAMPAIO, P. R. P., \& DAYCHOUM, M. T. (2017). Two decades of rail regulatory reform in Brazil (1996-2016). Utilities Policy. 49, 93-103

SCARAMUZZO, M. \& PEREIRA, R. (2016) Entrave na renovação de concessão causa incerteza em planos da Rumo. O Estado de São Paulo. Caderno Negócios. São Paulo, 31 de out. 2016.2 Disponível em: http://economia.estadao.com.br/noticias/negocios, entrave-na-renovacao-deconcessao-causa-incerteza-em-planos-da-rumo, 10000085492

SENADO (2016) Nota Técnica nº 148, de 2016, Consultoria de Orçamentos.

SENADO (2017) Ferrovia bioceânica é viável, dizem chineses em audiência pública. Agência Senado, 18 de abr. 2017. Disponível em: https://www12.senado.leg.br/noticias/materias/2017/04/18/ferrovia-bioceanica-e-viaveldizem-chineses-em-audiencia-publica 
SENNA, L. A. dos (2014) Economia e Planejamento dos Transportes. 1. Ed. Rio de Janeiro: Elsevier.

SEP (2016) Secretaria de Portos. Investidor russo estuda participar de leilão do dia 9 de junho. Assessoria de Comunicação Social, 11 de abr. 2016. Brasília-DF. Disponível em: http://www.portosdobrasil.gov.br/home-1/noticias/investidor-russo-estuda-participarde-leilao-do-dia-9-de-junho

SHAW, J., CHARLTON, C., \& GIBB, R. (1998). The competitive spirit re-awakens the ghost of railway monopoly. Transport Policy, 5(1), 37-49.

SILVA, C. (1904). Política e Legislação de Estradas de Ferro. Volume I. São Paulo. Typ. Laemmert \& Comp.

SILVEIRA, M. R. (2007) Estradas de ferro no Brasil: das primeiras construções às parceiras público-privadas. Rio de Janeiro. Editora Interciência.

SONG, M., ZHANG, G., ZENG, W., LIU, J., \& FANG, K. (2016). Railway transportation and environmental efficiency in China. Transportation Research Part D: Transport and Environment, 48, 488-498.

SUZUKI, H., MURAKAMI, J., HONG, Y. H., \& TAMAYOSE, B. (2015) Financing transitoriented development with land values: Adapting land value capture in developing countries. World Bank Publications.

SWEENEY, D. J., WILLIAMS, T. A., \& ANDERSON, D. R. (2013). Estatística aplicada à administração e economia. São Paulo, CENGAGE Learning.

TAKASAKI, E. A. (2014). O novo modelo brasileiro de exploração ferroviária. Dissertação de Mestrado em Economia do Setor Público. Departamento de Economia, Universidade de Brasília, Brasília, DF, 127p.

TCU (2014) Tribunal de Contas da União. Relatório de Fiscalização. TC 010.792/2014-7.

THÉRY, H., \& MELLO, N. A. (2005). Atlas do Brasil: Disparidades e dinâmicas do território. São Paulo, Edusp. 312p.

TOMEŠ, Z. (2017). Do European reforms increase modal shares of railways?. Transport Policy, 60, 143-151.

TURTELLI, C. (2017) Logística não segue avanço do agronegócio. O Estado de São Paulo, São Paulo, 7 de nov. 2017.

UIC (2017) L’Union Internacionale des chamins de fer. World High Speed Rolling Stock. Disponível em: https://uic.org/IMG/pdf/20171101_data_of_hs_trains.pdf . Acessado em 29, nov. 2017.

VALE, L., MONAI, R., FREITAS, T. G. de \& PINHEIRO, A. (2016) Arco Norte: o Desafio Logístico. Estudos Estratégicos n ${ }^{\circ}$ 6. Câmara dos Deputados, Centro de Estudos e Debates Estratégicos, Consultoria Legislativa. Edições Câmara. Brasília, DF, 392p.

VARIAN, H. (1947) Microeconomia: conceitos básicos. Rio de Janeiro: Elsevier, 2006 - $6^{\text {a }}$ reimpressão.

VLI (2016) Valor Logística Integrada. Disponível em: http://www.vli-logistica.com/pt-br 
WATERS II, W. G. (2007) Evolution of Railroad Economics. Research in Transportation Economics, v. 20, n. 1, p. 11-67, 2007. https://doi.org/10.1016/S0739-8859(07)20002$\underline{2}$

WANG, J., JIN, F., MO, H., \& WANG, F. (2009) Spatiotemporal evolution of China's railway network in the 20th century: An accessibility approach. Transportation Research Part A: Policy and Practice, 43(8), 765-778.

WANG, J. J., RONG, C., XU, J., \& OR, S. W. O. (2012). The funding of hierarchical railway development in China. Research in Transportation Economics, 35(1), 26-33.

WEF (2015) World Economic Forum. The Global Competitiveness Report 2015-2016. Disponível em: http://www3.weforum.org/docs/gcr/2015-2016/BRA.pdf .

WEF (2016) World Economic Forum. The Global Competitiveness Report 2016-2017 http://www3.weforum.org/docs/GCR2016-

2017/05FullReport/TheGlobalCompetitivenessReport2016-2017_FINAL.pdf

WEF (2017) World Economic Forum. The Global Competitiveness Report 2017-2018

WILSON, W. W. \& WILSON, W. W. (2001). Deregulation, rate incentives, and efficiency in the railroad market. Research in Transportation Economics, 6, 1-24.

WU, J. H., \& NASH, C. (2000). Railway reform in China. Transport Reviews, 20(1), 25-48.

YIN-NOR, L. T. (2015) Explaining Railway Reform in China: A Train of Property Rights Re-arrangements (Routledge Contemporary China Series)

ZHANG, H. (2016) Learning from Japan National Railway Reform, Advancing China National Railway Development and Reform. Ritsumeikan Asia Pacific University. Beppu, Japan. 36p. 


\title{
APÊNDICE A - Levantamento da Percepção dos Atores
}

\author{
Exploração econômica de ferrovias
}

Olá,

Gostaria de sua ajuda para realizar um levantamento sobre exploração econômica de ferrovias. Trata-se de pesquisa acadêmica no âmbito do Programa de Pós-Graduação em Transportes do Departamento de Engenharia Civil da Universidade de Brasília - UnB, do qual sou mestrando. São 29 perguntas sobre sua avaliação do atual cenário do setor ferroviário.

O tempo médio para todas as respostas é de 15 minutos.

As suas respostas serão anônimas.

Lembre-se que não existe resposta certa.

Queremos saber qual a sua percepção sobre a exploração das ferrovias no Brasil.

Também, não é necessário que você tenha opinião sobre todas as questões.

Entretanto, é muito importante para o êxito do estudo que todos os diferentes atores interessados expressem suas percepções do sistema ferroviário.

Muito Obrigado,

Marcos Kleber Ribeiro Felix

Mestrando PPGT/UnB

marcoskleber@aluno.unb.br

1. A que tipo de ator interessado você mais se identifica em relação ao setor ferroviário?

( ) Academia

( ) Concessionário Ferroviário

( ) Controlador ou Fiscalizador (Justiça, TCU, PF, IBAMA, etc)

( ) Governo (MT, PPI, EPL, DNIT, etc)

( ) Legislador (Câmara dos Deputados, Senado, etc)

( ) Regulador (ANTT, CADE, etc)

( ) Operador Ferroviário Independente

( ) Usuário

( ) Outros

2. Qual sua área de formação?

( ) Administração

( ) Direito

( ) Economia

( ) Engenharia

( ) Outra

3. Qual o seu grau de instrução?

( ) Nível Técnico

( ) Graduação

( ) Especialização

( ) Mestrado

( ) Doutorado

( ) Pós-Doutorado 
4. Quantos anos de experiência você possui no setor ferroviário?

( ) Menos de 1 ano

( ) Entre 1 e 5 anos

( ) Entre 6 e 10 anos

( ) Entre 11 e 15 anos

( ) Entre 16 e 20 anos

( ) Entre 21 e 25 anos

( ) Mais de 25 anos

\section{Avaliação Geral do Setor Ferroviário}

5. Como você avalia a extensão da malha ferroviária brasileira?

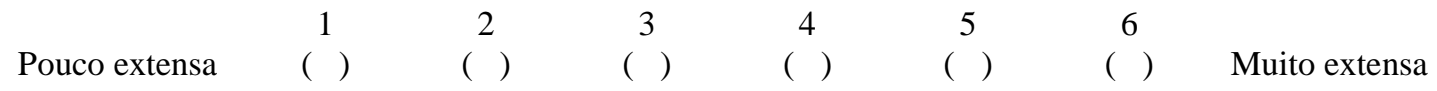

6. Como você avalia a qualidade da infraestrutura ferroviária brasileira?

\begin{tabular}{|c|c|c|c|c|c|}
\hline & 1 & 2 & 3 & 4 & \\
\hline
\end{tabular}

7. Como você avalia a quantidade da oferta de transporte ferroviário no Brasil?

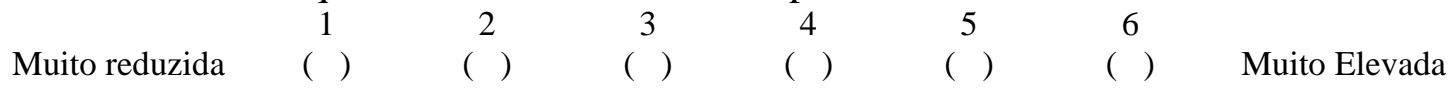

8. Como você avalia a demanda por transporte ferroviário no Brasil?

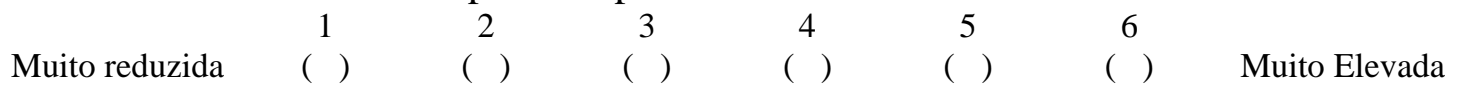

9. Como você avalia a rentabilidade das empresas ferroviárias brasileiras?

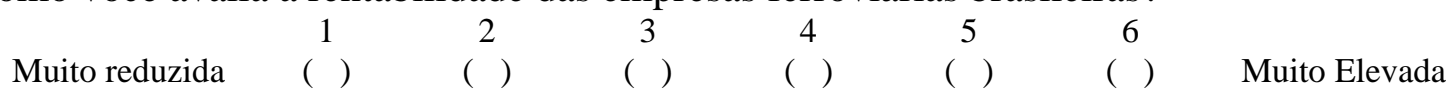

10. Como você avalia os preços dos fretes ferroviários no Brasil?

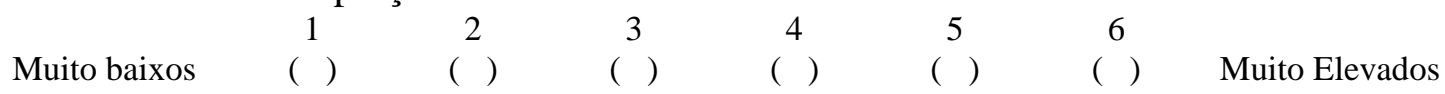

11. Como você avalia o grau de concorrência dos outros modos de transporte com o modo ferroviário no Brasil?

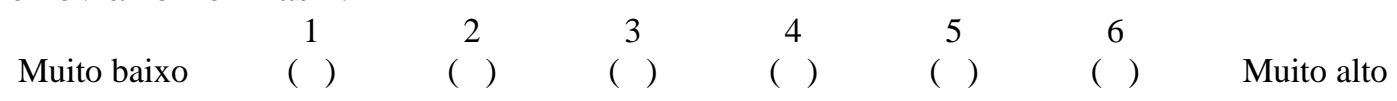

12. Como você avalia o grau de concorrência entre as concessionárias ferroviárias brasileiras?

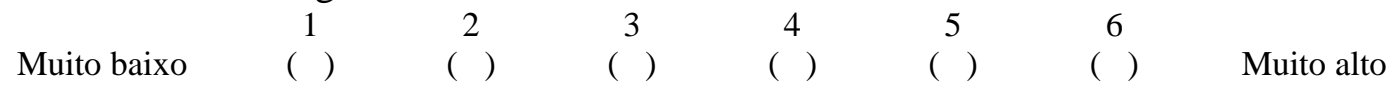

13. Como você avalia o grau de participação privada no setor ferroviário brasileiro?
Insuficiente

( $) \quad(2$
2
34
$4 \quad 5 \quad 6$
( )
( ) Excessivo

14. Como você avalia o grau de participação do Estado no setor ferroviário brasileiro? Insuficiente
( )
( )
( )
4
5
( )
Excessivo 
15. Como você avalia o grau de intervenção regulatória no setor ferroviário?

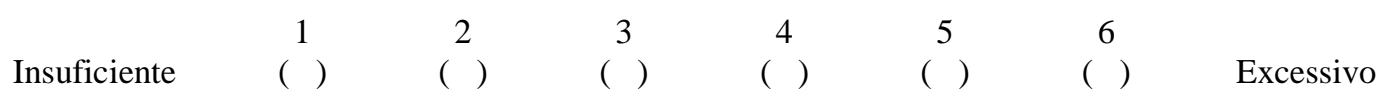

As próximas três questões são sobre sua avaliação quanto aos riscos inerentes à exploração ferroviária de CARGAS

16. Como você avalia os seguintes riscos, quanto à frequência em que ocorrem?

\begin{tabular}{|c|c|c|c|c|c|}
\hline & $\begin{array}{c}\text { Muitíssimo } \\
\text { improvável, } \\
\text { quase nunca } \\
\text { ocorre }\end{array}$ & $\begin{array}{c}\text { Pouco } \\
\text { provável, às } \\
\text { vezes ocorre }\end{array}$ & $\begin{array}{l}\text { Provável } \\
\text { ocorrer em } \\
\text { metade do } \\
\text { tempo }\end{array}$ & $\begin{array}{l}\text { Muito } \\
\text { provável, } \\
\text { ocorre com } \\
\text { frequência }\end{array}$ & $\begin{array}{l}\text { Muitíssimo } \\
\text { provável, } \\
\text { quase sempre } \\
\text { ocorre }\end{array}$ \\
\hline $\begin{array}{l}\text { Risco de Insegurança } \\
\text { jurídica }\end{array}$ & $(\quad)$ & $(\quad)$ & $($ ) & $(\quad)$ & $($ ) \\
\hline Risco de baixa demanda & $(\quad)$ & $(\quad)$ & $(\quad)$ & $(\quad)$ & $(\quad)$ \\
\hline $\begin{array}{l}\text { Risco de baixa } \\
\text { rentabilidade }\end{array}$ & () & $($ ( ) & ( ) & $($ ( ) & $(\quad)$ \\
\hline Risco de não financiamento & $(\quad)$ & $($ ) & $($ ) & $($ ) & $($ ) \\
\hline $\begin{array}{l}\text { Risco de não obtenção de } \\
\text { licenciamento ambiental }\end{array}$ & $($ ) & $(）$ & $($ ） & $(\quad)$ & $($ ) \\
\hline $\begin{array}{l}\text { Risco de elevação dos } \\
\text { custos de implantação }\end{array}$ & () & () & () & $($ ) & $(\quad)$ \\
\hline
\end{tabular}

17. Como você avalia os seguintes riscos, quanto à severidade?

\begin{tabular}{|c|c|c|c|c|c|}
\hline & $\begin{array}{l}\text { Pouquíssimo } \\
\text { importante }\end{array}$ & $\begin{array}{c}\text { Pouco } \\
\text { importante }\end{array}$ & $\begin{array}{c}\text { Média } \\
\text { importância }\end{array}$ & $\begin{array}{c}\text { Muito } \\
\text { importante }\end{array}$ & $\begin{array}{l}\text { Muitíssimo } \\
\text { Importante }\end{array}$ \\
\hline $\begin{array}{c}\text { Risco de Insegurança } \\
\text { jurídica }\end{array}$ & $($ ) & () & $(\quad)$ & $(）$ & $($ ) \\
\hline Risco de baixa demanda & $($ ) & ( ) & $($ ) & $($ ) & $(\quad)$ \\
\hline $\begin{array}{l}\text { Risco de baixa } \\
\text { rentabilidade }\end{array}$ & $($ ) & $($ ) & $($ ) & ( ) & $(）$ \\
\hline Risco de não financiamento & $($ ) & $($ ) & () & () & () \\
\hline $\begin{array}{l}\text { Risco de não obtenção de } \\
\text { licenciamento ambiental }\end{array}$ & $($ ) & $($ ) & $(\quad)$ & $($ ） & $($ ) \\
\hline $\begin{array}{l}\text { Risco de elevação dos } \\
\text { custos de implantação }\end{array}$ & $($ ) & ( ) & $($ ) & ( ) & $($ ) \\
\hline
\end{tabular}

18. Como você avalia os seguintes riscos, quanto à possibilidade de serem detectados?

\begin{tabular}{|c|c|c|c|c|c|}
\hline & $\begin{array}{c}\text { Quase } \\
\text { sempre } \\
\text { detectável }\end{array}$ & $\begin{array}{l}\text { Grandes } \\
\text { chances de } \\
\text { detecção }\end{array}$ & $\begin{array}{c}\text { Média } \\
\text { chance de } \\
\text { detecção }\end{array}$ & $\begin{array}{c}\text { Chance } \\
\text { muito baixa } \\
\text { de detecção }\end{array}$ & $\begin{array}{c}\text { Quase nunca } \\
\text { detectável }\end{array}$ \\
\hline $\begin{array}{c}\text { Risco de Insegurança } \\
\text { jurídica }\end{array}$ & $($ ) & ( ) & ( ) & $($ ) & ( ) \\
\hline Risco de baixa demanda & $(\quad)$ & $(\quad)$ & $(\quad)$ & $(\quad)$ & ( ) \\
\hline $\begin{array}{l}\text { Risco de baixa } \\
\text { rentabilidade }\end{array}$ & $(）$ & ( ) & $(\quad)$ & $(\quad)$ & ( ) \\
\hline Risco de não financiamento & $(\quad)$ & ( ) & $(\quad)$ & $(\quad)$ & $(\quad)$ \\
\hline $\begin{array}{l}\text { Risco de não obtenção de } \\
\text { licenciamento ambiental }\end{array}$ & ( ) & ( ) & $($ ） & $(\quad)$ & $($ ) \\
\hline $\begin{array}{l}\text { Risco de elevação dos } \\
\text { custos de implantação }\end{array}$ & $($ ) & ( ) & $($ ) & $($ ) & ( ) \\
\hline
\end{tabular}


As próximas três questões são sobre sua avaliação quanto aos riscos inerentes à exploração ferroviária de PASSAGEIROS

19. Como você avalia os seguintes riscos, quanto à frequência em que ocorrem?

\begin{tabular}{|c|c|c|c|c|c|}
\hline & $\begin{array}{l}\text { Muitíssimo } \\
\text { improvável, } \\
\text { quase nunca } \\
\text { ocorre }\end{array}$ & $\begin{array}{c}\text { Pouco } \\
\text { provável, às } \\
\text { vezes ocorre }\end{array}$ & $\begin{array}{c}\text { Provável } \\
\text { ocorrer em } \\
\text { metade do } \\
\text { tempo }\end{array}$ & $\begin{array}{l}\text { Muito } \\
\text { provável, } \\
\text { ocorre com } \\
\text { frequência }\end{array}$ & $\begin{array}{l}\text { Muitíssimo } \\
\text { provável, } \\
\text { quase sempre } \\
\text { ocorre }\end{array}$ \\
\hline $\begin{array}{l}\text { Risco de Insegurança } \\
\text { jurídica }\end{array}$ & ( ) & ( ) & ( ) & ( ) & $($ ) \\
\hline Risco de baixa demanda & ( ) & $($ ) & ( ) & $($ ) & ( ) \\
\hline $\begin{array}{l}\text { Risco de baixa } \\
\text { rentabilidade }\end{array}$ & ( ) & ( ) & ( ) & ( ) & ( ) \\
\hline Risco de não financiamento & ( ) & ( ) & ( ) & ( ) & ( ) \\
\hline $\begin{array}{l}\text { Risco de não obtenção de } \\
\text { licenciamento ambiental }\end{array}$ & ( ) & ( ) & ( ) & ( ) & ( ) \\
\hline $\begin{array}{l}\text { Risco de elevação dos } \\
\text { custos de implantação }\end{array}$ & ( ) & ( ) & ( ) & ( ) & ( ) \\
\hline
\end{tabular}

20. Como você avalia os seguintes riscos, quanto à severidade?

\begin{tabular}{|c|c|c|c|c|c|}
\hline & $\begin{array}{l}\text { Pouquíssimo } \\
\text { importante }\end{array}$ & $\begin{array}{l}\text { Pouco } \\
\text { importante }\end{array}$ & $\begin{array}{l}\text { Média } \\
\text { importância }\end{array}$ & $\begin{array}{l}\text { Muito } \\
\text { importante }\end{array}$ & $\begin{array}{l}\text { Muitíssimo } \\
\text { Importante }\end{array}$ \\
\hline $\begin{array}{l}\text { Risco de Insegurança } \\
\text { jurídica }\end{array}$ & ( ) & ( ) & ( ) & $($ ) & ( ) \\
\hline Risco de baixa demanda & ( ) & ( ) & ( ) & ( ) & ( ) \\
\hline $\begin{array}{l}\text { Risco de baixa } \\
\text { rentabilidade }\end{array}$ & ( ) & ( ) & ( ) & ( ) & ( ) \\
\hline Risco de não financiamento & $($ ) & ( ) & $($ ) & $($ ) & $($ ) \\
\hline $\begin{array}{l}\text { Risco de não obtenção de } \\
\text { licenciamento ambiental }\end{array}$ & $($ ) & () & $($ ) & $($ ) & $($ ) \\
\hline $\begin{array}{l}\text { Risco de elevação dos } \\
\text { custos de implantação }\end{array}$ & $($ ) & $($ ) & $($ ) & $($ ) & $($ ) \\
\hline
\end{tabular}

21. Como você avalia os seguintes riscos, quanto à possibilidade de serem detectados?

\begin{tabular}{|c|c|c|c|c|c|}
\hline & $\begin{array}{c}\text { Quase } \\
\text { sempre } \\
\text { detectável }\end{array}$ & $\begin{array}{l}\text { Grandes } \\
\text { chances de } \\
\text { detecção }\end{array}$ & $\begin{array}{c}\text { Média } \\
\text { chance de } \\
\text { detecção }\end{array}$ & $\begin{array}{c}\text { Chance } \\
\text { muito baixa } \\
\text { de detecção }\end{array}$ & $\begin{array}{l}\text { Quase nunca } \\
\text { detectável }\end{array}$ \\
\hline $\begin{array}{l}\text { Risco de Insegurança } \\
\text { jurídica }\end{array}$ & ( ) & ( ) & ( ) & ( ) & ( ) \\
\hline Risco de baixa demanda & ( ) & ( ) & ( ) & ( ) & ( ) \\
\hline $\begin{array}{l}\text { Risco de baixa } \\
\text { rentabilidade }\end{array}$ & ( ) & ( ) & ( ) & ( ) & ( ) \\
\hline Risco de não financiamento & $($ ) & ( ) & $($ ) & $($ ) & ( ) \\
\hline $\begin{array}{l}\text { Risco de não obtenção de } \\
\text { licenciamento ambiental }\end{array}$ & $($ ) & ( ) & ( ) & ( ) & ( ) \\
\hline $\begin{array}{l}\text { Risco de elevação dos } \\
\text { custos de implantação }\end{array}$ & ( ) & ( ) & ( ) & ( ) & ( ) \\
\hline
\end{tabular}


Avaliação de modelos alternativos de exploração ferroviária

22. Qual é o modelo de titularidade mais apropriado para as seguintes ferrovias?

\begin{tabular}{|c|c|c|c|c|}
\hline & $\begin{array}{l}\text { Integralmente } \\
\text { Privado }\end{array}$ & Concessão & $\begin{array}{l}\text { Integralmente } \\
\text { Público }\end{array}$ & $\begin{array}{l}\text { Não sei ou não se } \\
\text { aplica }\end{array}$ \\
\hline $\begin{array}{l}\text { EF-170 Ferrogrão (Miritituba - } \\
\text { Sinop) }\end{array}$ & ( ) & ( ) & ( ) & ( ) \\
\hline $\begin{array}{l}\text { EF-151 FNS - Ferrovia Norte } \\
\text { Sul (Palmas - Estrela d'Oeste) }\end{array}$ & ( ) & ( ) & ( ) & ( ) \\
\hline $\begin{array}{l}\text { EF-334 FIOL - Ferrovia de } \\
\text { Integração Oeste Leste (Ilhéus } \\
\text { Figueirópolis) }\end{array}$ & ( ) & ( ) & ( ) & $($ ) \\
\hline $\begin{array}{l}\text { EF-354 FICO - Ferrovia } \\
\text { Integração Centro-Oeste } \\
\text { (Acre-Goiás) }\end{array}$ & ( ) & ( ) & ( ) & $($ ) \\
\hline Nova Transnordestina & ( ) & ( ) & ( ) & ( ) \\
\hline Ferroanel - São Paulo & ( ) & ( ) & ( ) & ( ) \\
\hline Ferrovia Brasília-Goiânia & ( ) & ( ) & ( ) & ( ) \\
\hline Ferrovia Intercidades & ( ) & ( ) & ( ) & ( ) \\
\hline Rumo-ALL (Malha Paulista) & ( ) & ( ) & ( ) & ( ) \\
\hline MRS (Santos - Belo Horizonte) & ( ) & ( ) & ( ) & ( ) \\
\hline
\end{tabular}

23. Qual é o modelo de exploração mais apropriado para as seguintes ferrovias?

\begin{tabular}{|c|c|c|c|c|c|}
\hline & $\begin{array}{c}\text { Integração } \\
\text { vertical com } \\
\text { exclusividade }\end{array}$ & $\begin{array}{c}\text { Integração } \\
\text { vertical com } \\
\text { permissão de } \\
\text { tráfego mútuo }\end{array}$ & $\begin{array}{c}\text { Integração } \\
\text { vertical com } \\
\text { permissão de } \\
\text { direito de } \\
\text { passagem }\end{array}$ & Open access & $\begin{array}{l}\text { Não sei ou } \\
\text { não se aplica }\end{array}$ \\
\hline $\begin{array}{l}\text { EF-170 Ferrogrão } \\
\text { (Miritituba - Sinop) }\end{array}$ & $($ ) & ( ) & $($ ) & ( ) & ( ) \\
\hline $\begin{array}{l}\text { EF-151 FNS - Ferrovia } \\
\text { Norte Sul (Palmas - Estrela } \\
\text { d'Oeste) }\end{array}$ & ( ) & $($ ) & $($ ) & ( ) & ( ) \\
\hline $\begin{array}{l}\text { EF-334 FIOL - Ferrovia de } \\
\text { Integração Oeste Leste } \\
\text { (Ilhéus Figueirópolis) }\end{array}$ & ( ) & ( ) & ( ) & ( ) & ( ) \\
\hline $\begin{array}{l}\text { EF-354 FICO - Ferrovia } \\
\text { Integração Centro-Oeste } \\
\text { (Acre-Goiás) }\end{array}$ & $($ ) & ( ) & $($ ) & ( ) & ( ) \\
\hline Nova Transnordestina & ( ) & $($ ) & $($ ) & $($ ) & $($ ) \\
\hline Ferroanel - São Paulo & () & ( ) & ( ) & ( ) & () \\
\hline Ferrovia Brasília-Goiânia & () & ( ) & ( ) & ( ) & () \\
\hline Ferrovia Intercidades & ( ) & ( ) & ( ) & ( ) & ( ) \\
\hline $\begin{array}{l}\text { Rumo-ALL (Malha } \\
\text { Paulista) }\end{array}$ & ( ) & ( ) & ( ) & ( ) & ( ) \\
\hline $\begin{array}{l}\text { MRS (Santos - Belo } \\
\text { Horizonte) }\end{array}$ & $($ ) & ( ) & $($ ) & ( ) & ( ) \\
\hline
\end{tabular}


24. Qual é o critério de outorga mais apropriado para as seguintes ferrovias?

\begin{tabular}{|c|c|c|c|c|c|c|}
\hline & $\begin{array}{l}\text { Menor } \\
\text { valor de } \\
\text { tarifa }\end{array}$ & $\begin{array}{l}\text { Menor valor de } \\
\text { contraprestação } \\
\text { pública }\end{array}$ & $\begin{array}{c}\text { Maior } \\
\text { valor de } \\
\text { outorga } \\
\text { privada }\end{array}$ & $\begin{array}{c}\text { Menor } \\
\text { tempo de } \\
\text { exploração }\end{array}$ & $\begin{array}{c}\text { Maior } \\
\text { capacidade de } \\
\text { movimentação } \\
\text { de carga }\end{array}$ & $\begin{array}{l}\text { Não sei } \\
\text { ou não se } \\
\text { aplica }\end{array}$ \\
\hline $\begin{array}{l}\text { EF-170 Ferrogrão } \\
\text { (Miritituba - Sinop) }\end{array}$ & () & $($ ) & $($ ) & $($ ) & $($ ) & $($ ) \\
\hline $\begin{array}{l}\text { EF-151 FNS - } \\
\text { Ferrovia Norte Sul } \\
\text { (Palmas - Estrela } \\
\text { d'Oeste) }\end{array}$ & $($ ) & $($ ) & $($ ) & $($ ) & () & () \\
\hline $\begin{array}{l}\text { EF-334 FIOL - } \\
\text { Ferrovia de Integração } \\
\text { Oeste Leste (Ilhéus } \\
\text { Figueirópolis) }\end{array}$ & () & () & $($ ) & $($ ( ) & $($ ) & $($ ) \\
\hline $\begin{array}{l}\text { EF-354 FICO - } \\
\text { Ferrovia Integração } \\
\text { Centro-Oeste (Acre-- } \\
\text { Goiás) }\end{array}$ & $($ ) & $($ ) & $(\quad)$ & $($ ) & $($ ) & $($ ) \\
\hline Nova Transnordestina & () & () & $(\quad)$ & $(\quad)$ & () & () \\
\hline Ferroanel - São Paulo & () & () & $(\quad)$ & $(\quad)$ & $(\quad)$ & $(\quad)$ \\
\hline $\begin{array}{l}\text { Ferrovia Brasília- } \\
\text { Goiânia }\end{array}$ & $($ ) & $(\quad)$ & $($ ) & $($ ） & $($ ） & () \\
\hline Ferrovia Intercidades & () & $(\quad)$ & $(\quad)$ & $(\quad)$ & $(\quad)$ & $(\quad)$ \\
\hline $\begin{array}{l}\text { Rumo-ALL (Malha } \\
\text { Paulista) }\end{array}$ & $($ ) & $($ ) & $($ ) & $(\quad)$ & $(）$ & $(\quad)$ \\
\hline $\begin{array}{l}\text { MRS (Santos - Belo } \\
\text { Horizonte) }\end{array}$ & $(\quad)$ & $(\quad)$ & $(\quad)$ & $(\quad)$ & $(\quad)$ & $(\quad)$ \\
\hline
\end{tabular}

25. Qual a bitola mais apropriada para as seguintes ferrovias?

\begin{tabular}{|c|c|c|c|c|c|}
\hline & Larga & Standard & Estreita & Mista & $\begin{array}{l}\text { Não sei ou } \\
\text { não se aplica }\end{array}$ \\
\hline $\begin{array}{l}\text { EF-170 Ferrogrão (Miritituba - } \\
\text { Sinope) }\end{array}$ & $($ ) & $(\quad)$ & $(\quad)$ & $(\quad)$ & $(）$ \\
\hline $\begin{array}{l}\text { EF-151 FNS - Ferrovia Norte } \\
\text { Sul (Palmas - Estrela d'Oeste) }\end{array}$ & $($ ) & $(\quad)$ & $(\quad)$ & $(\quad)$ & $(\quad)$ \\
\hline $\begin{array}{c}\text { EF-334 FIOL - Ferrovia de } \\
\text { Integração Oeste Leste (Ilhéus } \\
\text { Figueirópolis) }\end{array}$ & $(\quad)$ & $($ ） & $(\quad)$ & ( ) & $($ ） \\
\hline $\begin{array}{c}\text { EF-354 FICO - Ferrovia } \\
\text { Integração Centro-Oeste } \\
\text { (Acre-Goiás) }\end{array}$ & $($ ) & ( ) & ( ) & ( ) & ( ) \\
\hline Nova Transnordestina & () & $(\quad)$ & $(\quad)$ & $(\quad)$ & $(\quad)$ \\
\hline Ferroanel - São Paulo & () & $(\quad)$ & $(\quad)$ & $(\quad)$ & $(\quad)$ \\
\hline Ferrovia Brasília-Goiânia & ( ) & ( ) & $(）$ & ( ) & ( ) \\
\hline Ferrovia Intercidades & $(\quad)$ & ( ) & $(\quad)$ & ( ) & ( ) \\
\hline Rumo-ALL (Malha Paulista) & () & ( ) & $(\quad)$ & ( ) & ( ) \\
\hline MRS (Santos - Belo Horizonte) & $(\quad)$ & ( ) & ( ) & ( ) & ( ) \\
\hline
\end{tabular}


26. Qual o grau de utilidade das seguintes ferrovias?

\begin{tabular}{|c|c|c|c|c|c|c|}
\hline & $\begin{array}{l}\text { Pouquíssimo } \\
\text { útil }\end{array}$ & Pouco útil & Útil & Muito útil & $\begin{array}{l}\text { Muitíssimo } \\
\text { útil }\end{array}$ & $\begin{array}{l}\text { Não sei } \\
\text { ou não se } \\
\text { aplica }\end{array}$ \\
\hline $\begin{array}{l}\text { EF-170 Ferrogrão } \\
\text { (Miritituba - Sinop) }\end{array}$ & ( ) & ( ) & () & $($ ) & $($ ) & $($ ) \\
\hline $\begin{array}{l}\text { EF-151 FNS - } \\
\text { Ferrovia Norte Sul } \\
\text { (Palmas - Estrela } \\
\text { d'Oeste) }\end{array}$ & $($ ) & () & $($ ) & $($ ) & $($ ) & $($ ) \\
\hline $\begin{array}{l}\text { EF-334 FIOL - } \\
\text { Ferrovia de Integração } \\
\text { Oeste Leste (Ilhéus } \\
\text { Figueirópolis) }\end{array}$ & ( ) & ( ) & $($ ) & ( ) & $($ ) & $($ ) \\
\hline $\begin{array}{l}\text { EF-354 FICO - } \\
\text { Ferrovia Integração } \\
\text { Centro-Oeste (Acre- } \\
\text { Goiás) }\end{array}$ & ( ) & $($ ) & $($ ) & $($ ) & $($ ) & $($ ) \\
\hline Nova Transnordestina & ( ) & ( ) & ( ) & ( ) & ( ) & ( ) \\
\hline Ferroanel - São Paulo & ( ) & ( ) & ( ) & ( ) & ( ) & ( ) \\
\hline $\begin{array}{l}\text { Ferrovia Brasília- } \\
\text { Goiânia }\end{array}$ & ( ) & ( ) & ( ) & ( ) & ( ) & ( ) \\
\hline Ferrovia Intercidades & ( ) & ( ) & ( ) & ( ) & ( ) & ( ) \\
\hline $\begin{array}{l}\text { Rumo-ALL (Malha } \\
\text { Paulista) }\end{array}$ & ( ) & ( ) & ( ) & ( ) & ( ) & ( ) \\
\hline $\begin{array}{l}\text { MRS (Santos - Belo } \\
\text { Horizonte) }\end{array}$ & ( ) & $($ ) & $($ ) & $($ ) & $($ ) & $($ ) \\
\hline
\end{tabular}

27. Qual o grau de viabilidade econômica das seguintes ferrovias?

\begin{tabular}{|c|c|c|c|c|c|c|}
\hline & $\begin{array}{l}\text { Pouquíssimo } \\
\text { viável }\end{array}$ & Pouco viável & Viável & $\begin{array}{l}\text { Muito } \\
\text { viável }\end{array}$ & $\begin{array}{l}\text { Muitíssimo } \\
\text { viável }\end{array}$ & $\begin{array}{c}\text { Não sei } \\
\text { ou não se } \\
\text { aplica }\end{array}$ \\
\hline $\begin{array}{l}\text { EF-170 Ferrogrão } \\
\text { (Miritituba - Sinop) }\end{array}$ & $($ ) & () & $($ ) & $($ ) & $($ ) & $($ ) \\
\hline $\begin{array}{l}\text { EF-151 FNS - } \\
\text { Ferrovia Norte Sul } \\
\text { (Palmas - Estrela } \\
\text { d'Oeste) }\end{array}$ & ( ) & $($ ) & $($ ) & $($ ) & $($ ) & $($ ) \\
\hline $\begin{array}{l}\text { EF-334 FIOL - } \\
\text { Ferrovia de Integração } \\
\text { Oeste Leste (Ilhéus } \\
\text { Figueirópolis) }\end{array}$ & ( ) & $($ ) & $($ ) & $($ ) & $($ ) & () \\
\hline $\begin{array}{l}\text { EF-354 FICO - } \\
\text { Ferrovia Integração } \\
\text { Centro-Oeste (Acre- } \\
\text { Goiás) }\end{array}$ & $($ ) & $($ ) & $($ ) & $($ ) & $($ ) & $($ ) \\
\hline Nova Transnordestina & ( ) & ( ) & $($ ) & ( ) & ( ) & ( ) \\
\hline Ferroanel - São Paulo & ( ) & ( ) & ( ) & ( ) & ( ) & ( ) \\
\hline $\begin{array}{l}\text { Ferrovia Brasília- } \\
\text { Goiânia }\end{array}$ & ( ) & ( ) & ( ) & ( ) & ( ) & ( ) \\
\hline Ferrovia Intercidades & $($ ) & $($ ) & $($ ) & $($ ) & $($ ) & $($ ) \\
\hline $\begin{array}{l}\text { Rumo-ALL (Malha } \\
\text { Paulista) }\end{array}$ & ( ) & ( ) & ( ) & ( ) & ( ) & ( ) \\
\hline $\begin{array}{l}\text { MRS (Santos - Belo } \\
\text { Horizonte) }\end{array}$ & $($ ) & $($ ) & ( ) & $($ ) & $($ ) & $($ ) \\
\hline
\end{tabular}


28. Qual o grau de prioridade para construção das seguintes ferrovias?

\begin{tabular}{|c|c|c|c|c|c|c|}
\hline & $\begin{array}{l}\text { Muito } \\
\text { baixo }\end{array}$ & Baixo & Normal & Urgente & Urgentíssimo & $\begin{array}{l}\text { Não sei } \\
\text { ou não se } \\
\text { aplica }\end{array}$ \\
\hline $\begin{array}{l}\text { EF-170 Ferrogrão } \\
\text { (Miritituba - Sinop) }\end{array}$ & $($ ) & ( ) & $($ ) & $($ ) & ( ) & $($ ) \\
\hline $\begin{array}{l}\text { EF-151 FNS - } \\
\text { Ferrovia Norte Sul } \\
\text { (Palmas - Estrela } \\
\text { d'Oeste) }\end{array}$ & ( ) & ( ) & $($ ) & ( ) & ( ) & ( ) \\
\hline $\begin{array}{l}\text { EF-334 FIOL - } \\
\text { Ferrovia de Integração } \\
\text { Oeste Leste (Ilhéus } \\
\text { Figueirópolis) }\end{array}$ & $($ ) & ( ) & ( ) & ( ) & $($ ) & $($ ) \\
\hline $\begin{array}{l}\text { EF-354 FICO - } \\
\text { Ferrovia Integração } \\
\text { Centro-Oeste (Acre-- } \\
\text { Goiás) }\end{array}$ & ( ) & ( ) & ( ) & ( ) & ( ) & ( ) \\
\hline Nova Transnordestina & ( ) & ( ) & $($ ) & ( ) & ( ) & ( ) \\
\hline Ferroanel - São Paulo & ( ) & ( ) & ( ) & ( ) & ( ) & ( ) \\
\hline $\begin{array}{l}\text { Ferrovia Brasília- } \\
\text { Goiânia }\end{array}$ & ( ) & ( ) & ( ) & ( ) & ( ) & ( ) \\
\hline Ferrovia Intercidades & $($ ) & ( ) & $($ ) & $($ ) & ( ) & ( ) \\
\hline $\begin{array}{l}\text { Rumo-ALL (Malha } \\
\text { Paulista) }\end{array}$ & ( ) & ( ) & ( ) & ( ) & ( ) & ( ) \\
\hline $\begin{array}{l}\text { MRS (Santos - Belo } \\
\text { Horizonte) }\end{array}$ & ( ) & ( ) & $($ ) & ( ) & ( ) & ( ) \\
\hline
\end{tabular}

29. Há algum outro dado julgado útil que deseja comentar? 


\section{APÊNDICE B - Frequência das Variáveis Homogêneas}

Tabela B.1 Frequência da variável titularidade para as 10 ferrovias estudadas

\begin{tabular}{|c|c|c|c|c|c|}
\hline & 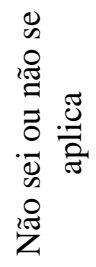 & 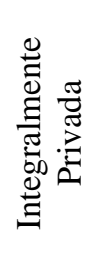 & 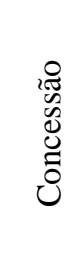 & 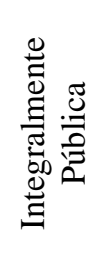 & $\underset{0}{\stackrel{\pi}{0}}$ \\
\hline EF-170 Ferrogrão (Miritituba - Sinop) & 18 & 18 & 30 & 3 & 69 \\
\hline $\begin{array}{l}\text { EF-151 FNS - Ferrovia Norte Sul (Palmas - } \\
\text { Estrela d'Oeste) }\end{array}$ & 14 & 9 & 40 & 6 & 69 \\
\hline $\begin{array}{l}\text { EF-334 FIOL - Ferrovia de Integração Oeste } \\
\text { Leste (Ilhéus Figueirópolis) }\end{array}$ & 17 & 11 & 37 & 4 & 69 \\
\hline $\begin{array}{l}\text { EF-354 FICO - Ferrovia Integração Centro- } \\
\text { Oeste (Acre-Goiás) }\end{array}$ & 16 & 11 & 37 & 5 & 69 \\
\hline Nova Transnordestina & 12 & 12 & 37 & 8 & 69 \\
\hline Ferroanel - São Paulo & 12 & 18 & 33 & 6 & 69 \\
\hline Ferrovia Transpequi (Brasília - Goiânia) & 14 & 20 & 31 & 4 & 69 \\
\hline Ferrovia Intercidades - Campinas - Santos & 13 & 17 & 33 & 6 & 69 \\
\hline Rumo-ALL (Malha Paulista) & 12 & 12 & 42 & 3 & 69 \\
\hline MRS (Santos - Belo Horizonte) & 12 & 15 & 39 & 3 & 69 \\
\hline \multirow{3}{*}{$\begin{array}{r}\text { Frequência total } \\
\text { Percentagem total } \\
\text { Percentagem sem a resposta "não sei ou não se } \\
\text { aplica" }\end{array}$} & 140 & 143 & 359 & 48 & 690 \\
\hline & 0,20 & 0,21 & 0,52 & 0,07 & 1,00 \\
\hline & - & 0,26 & 0,65 & 0,09 & 1,00 \\
\hline
\end{tabular}

Tabela B.2 Frequência da variável exploração para as 10 ferrovias estudadas

\begin{tabular}{|c|c|c|c|c|c|c|}
\hline & 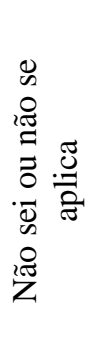 & 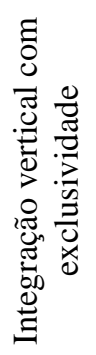 & 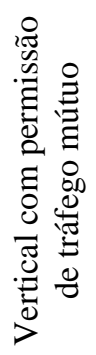 & 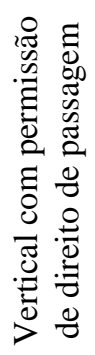 & 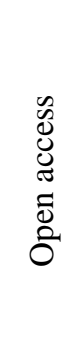 & 胥 \\
\hline EF-170 Ferrogrão (Miritituba - Sinop) & 29 & 6 & 7 & 13 & 14 & 69 \\
\hline $\begin{array}{l}\text { EF-151 FNS - Ferrovia Norte Sul } \\
\text { (Palmas - Estrela d'Oeste) }\end{array}$ & 26 & 3 & 6 & 17 & 17 & 69 \\
\hline $\begin{array}{l}\text { EF-334 FIOL - Ferrovia de Integração } \\
\text { Oeste Leste (Ilhéus Figueirópolis) }\end{array}$ & 27 & 3 & 6 & 18 & 15 & 69 \\
\hline $\begin{array}{l}\text { EF-354 FICO - Ferrovia Integração } \\
\text { Centro-Oeste (Acre-Goiás) }\end{array}$ & 28 & 3 & 5 & 17 & 16 & 69 \\
\hline Nova Transnordestina & 26 & 4 & 5 & 18 & 16 & 69 \\
\hline Ferroanel - São Paulo & 24 & 3 & 6 & 16 & 20 & 69 \\
\hline Ferrovia Transpequi (Brasília - Goiânia) & 29 & 5 & 4 & 16 & 15 & 69 \\
\hline $\begin{array}{l}\text { Ferrovia Intercidades }- \text { Campinas - } \\
\text { Santos }\end{array}$ & 24 & 5 & 6 & 18 & 16 & 69 \\
\hline Rumo-ALL (Malha Paulista) & 24 & 3 & 5 & 19 & 18 & 69 \\
\hline MRS (Santos - Belo Horizonte) & 24 & 3 & 6 & 20 & 16 & 69 \\
\hline $\begin{array}{ll}\text { Frequência total } \\
\end{array}$ & 261 & 38 & 56 & 172 & 163 & 690 \\
\hline Percentagem total & 0,38 & 0,06 & 0,08 & 0,25 & 0,24 & 1,00 \\
\hline $\begin{array}{r}\text { Percentagem sem a resposta "não sei ou } \\
\text { não se aplica" }\end{array}$ & - & 0,09 & 0,13 & 0,40 & 0,38 & 1,00 \\
\hline
\end{tabular}




\begin{tabular}{|c|c|c|c|c|c|c|c|}
\hline & 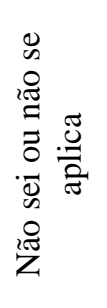 & 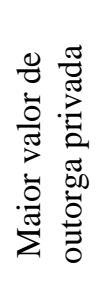 & 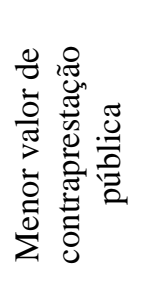 & 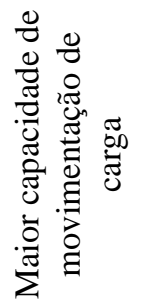 & 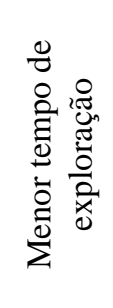 & 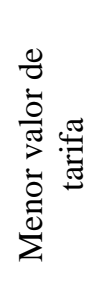 & $\underset{0}{\tilde{\pi}}$ \\
\hline EF-170 Ferrogrão (Miritituba - Sinop) & 28 & 9 & 6 & 13 & 0 & 13 & 69 \\
\hline $\begin{array}{l}\text { EF-151 FNS - Ferrovia Norte Sul } \\
\text { (Palmas - Estrela d'Oeste) }\end{array}$ & 29 & 10 & 6 & 9 & 0 & 15 & 69 \\
\hline $\begin{array}{l}\text { EF-334 FIOL - Ferrovia de Integração } \\
\text { Oeste Leste (Ilhéus Figueirópolis) }\end{array}$ & 28 & 11 & 6 & 6 & 1 & 17 & 69 \\
\hline $\begin{array}{l}\text { EF-354 FICO - Ferrovia Integração } \\
\text { Centro-Oeste (Acre-Goiás) }\end{array}$ & 31 & 9 & 5 & 8 & 0 & 16 & 69 \\
\hline Nova Transnordestina & 28 & 11 & 8 & 8 & 0 & 14 & 69 \\
\hline Ferroanel - São Paulo & 25 & 11 & 6 & 8 & 0 & 19 & 69 \\
\hline Ferrovia Transpequi (Brasília - Goiânia) & 28 & 10 & 6 & 5 & 0 & 20 & 69 \\
\hline $\begin{array}{l}\text { Ferrovia Intercidades - Campinas - } \\
\text { Santos }\end{array}$ & 24 & 11 & 6 & 6 & 1 & 21 & 69 \\
\hline Rumo-ALL (Malha Paulista) & 26 & 11 & 5 & 10 & 0 & 17 & 69 \\
\hline MRS (Santos - Belo Horizonte) & 26 & 11 & 6 & 11 & 0 & 15 & 69 \\
\hline Frequência total & 273 & 104 & 60 & 84 & 2 & 167 & 690 \\
\hline Percentagem total & 0,40 & 0,15 & 0,09 & 0,12 & 0,003 & 0,24 & 1,00 \\
\hline $\begin{array}{r}\text { Percentagem sem a resposta "não sei ou } \\
\text { não se aplica" }\end{array}$ & - & 0,25 & 0,14 & 0,20 & 0,005 & 0,40 & 1,00 \\
\hline
\end{tabular}

Tabela B.4 Frequência da variável bitola para as 10 ferrovias estudadas

\begin{tabular}{|c|c|c|c|c|c|c|}
\hline & 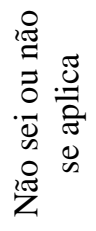 & 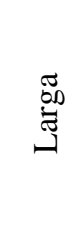 & $\begin{array}{l}\frac{\pi}{5} \\
\frac{5}{5} \\
\frac{5}{5}\end{array}$ & 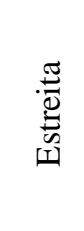 & 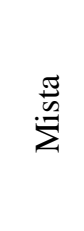 & 䒿 \\
\hline EF-170 Ferrogrão (Miritituba - Sinop) & 31 & 27 & 5 & 0 & 6 & 69 \\
\hline $\begin{array}{l}\text { EF-151 FNS - Ferrovia Norte Sul } \\
\text { (Palmas - Estrela d'Oeste) }\end{array}$ & 30 & 27 & 4 & 1 & 7 & 69 \\
\hline $\begin{array}{l}\text { EF-334 FIOL - Ferrovia de Integração } \\
\text { Oeste Leste (Ilhéus Figueirópolis) }\end{array}$ & 31 & 27 & 4 & 0 & 7 & 69 \\
\hline $\begin{array}{l}\text { EF-354 FICO - Ferrovia Integração } \\
\text { Centro-Oeste (Acre-Goiás) }\end{array}$ & 33 & 26 & 3 & 0 & 7 & 69 \\
\hline Nova Transnordestina & 32 & 22 & 4 & 2 & 9 & 69 \\
\hline Ferroanel - São Paulo & 29 & 24 & 5 & 1 & 10 & 69 \\
\hline $\begin{array}{llll}\text { Ferrovia } & \text { Transpequi } & \text { (Brasília } & - \\
\text { Goiânia) } & & & \end{array}$ & 33 & 22 & 6 & 3 & 5 & 69 \\
\hline $\begin{array}{l}\text { Ferrovia Intercidades - Campinas - } \\
\text { Santos }\end{array}$ & 29 & 22 & 8 & 2 & 8 & 69 \\
\hline Rumo-ALL (Malha Paulista) & 29 & 23 & 5 & 1 & 11 & 69 \\
\hline MRS (Santos - Belo Horizonte) & 29 & 25 & 6 & 1 & 8 & 69 \\
\hline Frequência total & 306 & 245 & 50 & 11 & 78 & 690 \\
\hline Percentagem total & 0,44 & 0,36 & 0,07 & 0,02 & 0,11 & 1,00 \\
\hline $\begin{array}{r}\text { Percentagem sem a resposta "não sei } \\
\text { ou não se aplica" }\end{array}$ & - & 0,64 & 0,13 & 0,03 & 0,20 & 1,00 \\
\hline
\end{tabular}




\section{APÊNDICE C - Extensão da Rede por ano e km}

Tabela C.1 Extensão da rede ferroviária por anos e países selecionados em $\mathbf{k m}$

\begin{tabular}{|c|c|c|c|c|c|c|c|c|c|}
\hline Ano & EUA & Inglaterra & Brasil & China & Ano & EUA & Inglaterra & Brasil & China \\
\hline 1830 & 86 & 111 & & & 1983 & 250.854 & & 29.207 & \\
\hline 1840 & 4.519 & 2.141 & & & 1986 & 234.584 & & 29.814 & \\
\hline 1845 & & & & & 1988 & & & 29.777 & 52.767 \\
\hline 1850 & 14.518 & & & & 1990 & & & 30.129 & 53.378 \\
\hline 1854 & & & 15 & & 1993 & & & 30.379 & \\
\hline 1855 & & & & & 1995 & & & 25.599 & 59.634 \\
\hline 1857 & 41.900 & 10.220 & 16 & & 2000 & & & & 68.656 \\
\hline 1859 & & 11.234 & 109 & & 2005 & & & & 75.000 \\
\hline 1860 & 48.280 & & 223 & & 2007 & & & & 77.966 \\
\hline 1870 & 85.169 & & 745 & & 2008 & & & & 79.687 \\
\hline 1876 & & & 2.122 & 15 & 2009 & & & & 85.818 \\
\hline 1878 & & & 2.709 & & 2010 & & & & 90.504 \\
\hline 1880 & 150.098 & & 3.398 & & 2011 & & & & 93.200 \\
\hline 1888 & & & 9.321 & & 2012 & & & & 97.600 \\
\hline 1889 & & 24.221 & 9.583 & & 2013 & & & & 103.144 \\
\hline 1890 & 263.283 & & 9.973 & & 2014 & 222.857 & & 29.165 & 112.000 \\
\hline 1895 & & & 12.967 & 467 & 2015 & & & & 121.000 \\
\hline 1900 & 311.159 & & 15.316 & & 2016 & & & & 124.000 \\
\hline 1901 & & & 15.506 & & 2017 & & & 29.075 & \\
\hline 1906 & & & 17.246 & 5.962 & & & & & \\
\hline 1911 & & & 22.287 & 9.292 & & & & & \\
\hline 1916 & 408.832 & & 27.015 & & & & & & \\
\hline 1925 & & & 30.732 & 12.302 & & & & & \\
\hline 1937 & & & 38.287 & 21.761 & & & & & \\
\hline 1939 & 378.298 & & 34.204 & & & & & & \\
\hline 1945 & 364.831 & & 35.280 & & & & & & \\
\hline 1947 & 363.399 & & 35.451 & & & & & & \\
\hline 1949 & & & 35.970 & 21.810 & & & & & \\
\hline 1955 & 340.309 & & 37.092 & 25.600 & & & & & \\
\hline 1957 & & & 37.422 & 26.708 & & & & & \\
\hline 1960 & 350.115 & & 38.287 & & & & & & \\
\hline 1963 & 345.022 & & 35.349 & & & & & & \\
\hline 1965 & 341.059 & & 33.864 & 36.406 & & & & & \\
\hline 1970 & 316.202 & & 31.848 & 41.000 & & & & & \\
\hline 1974 & 310.588 & & 30.474 & 45.093 & & & & & \\
\hline 1980 & 265.255 & & 29.659 & 53.300 & & & & & \\
\hline 1981 & & & 29.237 & 50.181 & & & & & \\
\hline
\end{tabular}

Fontes: Campos (2001); Cavalcanti (2010); NBS (2017); Silva (1904); Wang et al., (2009); 


\section{APÊNDICE D - Dados sobre extensão, qualidade e densidade.}

Tabela D.1 Qualidade, extensão e densidade por países selecionados

\begin{tabular}{|c|c|c|c|c|c|c|}
\hline País & $\begin{array}{l}\text { Qualidade } \\
\text { Rank }\end{array}$ & $\begin{array}{l}\text { Índice Qualidade } \\
\text { Ferrovia }\end{array}$ & Extensão Rank & Área $\left(\mathrm{km}^{2}\right)$ & $\begin{array}{l}\text { Densidade } \\
\left(1000 \mathrm{~km} / \mathrm{km}^{2}\right)\end{array}$ & Extensão $(\mathrm{km})$ \\
\hline Estados Unidos & 13 & 5,1 & & 9.147 .593 & 32,09 & 293.564 \\
\hline China & 14 & 5,1 & 2 & 9.326 .410 & 20,51 & 191.270 \\
\hline Rússia & 25 & 4,4 & & 16.377 .742 & 5,32 & 87.157 \\
\hline Canadá & 18 & 4,8 & & 9.093 .507 & 8,57 & 77.932 \\
\hline Índia & 23 & 4,5 & & 2.973 .193 & 23,05 & 68.525 \\
\hline Alemanha & 11 & 5,4 & & 348.672 & 124,67 & 43.468 \\
\hline Austrália & 36 & 4,4 & & 7.682 .300 & 4,81 & 36.968 \\
\hline Argentina & 87 & 2,1 & & 2.736 .690 & 13,49 & 36.917 \\
\hline França & 4 & 5,8 & & 640.427 & 46,28 & 29.640 \\
\hline Brasil & 93 & 1,9 & 10 & 8.358 .140 & 3,41 & 28.538 \\
\hline Japão & 1 & 6,7 & 11 & 364.485 & 74,93 & 27.311 \\
\hline Suíça & 2 & 6,6 & 33 & 39.997 & 141,31 & 5.652 \\
\hline Hong Kong & 3 & 6,4 & & 1.104 & & \\
\hline Cingapura & 5 & 5,7 & & 716 & & \\
\hline Finlândia & 6 & 5,7 & 32 & 303.815 & 19,48 & 5.919 \\
\hline Holanda & 7 & 5,6 & 56 & 33.893 & 95,09 & 3.223 \\
\hline Espanha & 8 & 5,6 & 17 & 498.980 & 32,27 & 16.102 \\
\hline Coreia do Sul & 9 & 5,5 & 52 & 96.920 & 35,70 & 3.460 \\
\hline Taiwan & 10 & 5,4 & 79 & 32.260 & 49,50 & 1.597 \\
\hline
\end{tabular}




\section{APÊNDICE E - Dados sobre bitola, População e PIB}

Tabela E.1 Bitola, população e PIB por países selecionados

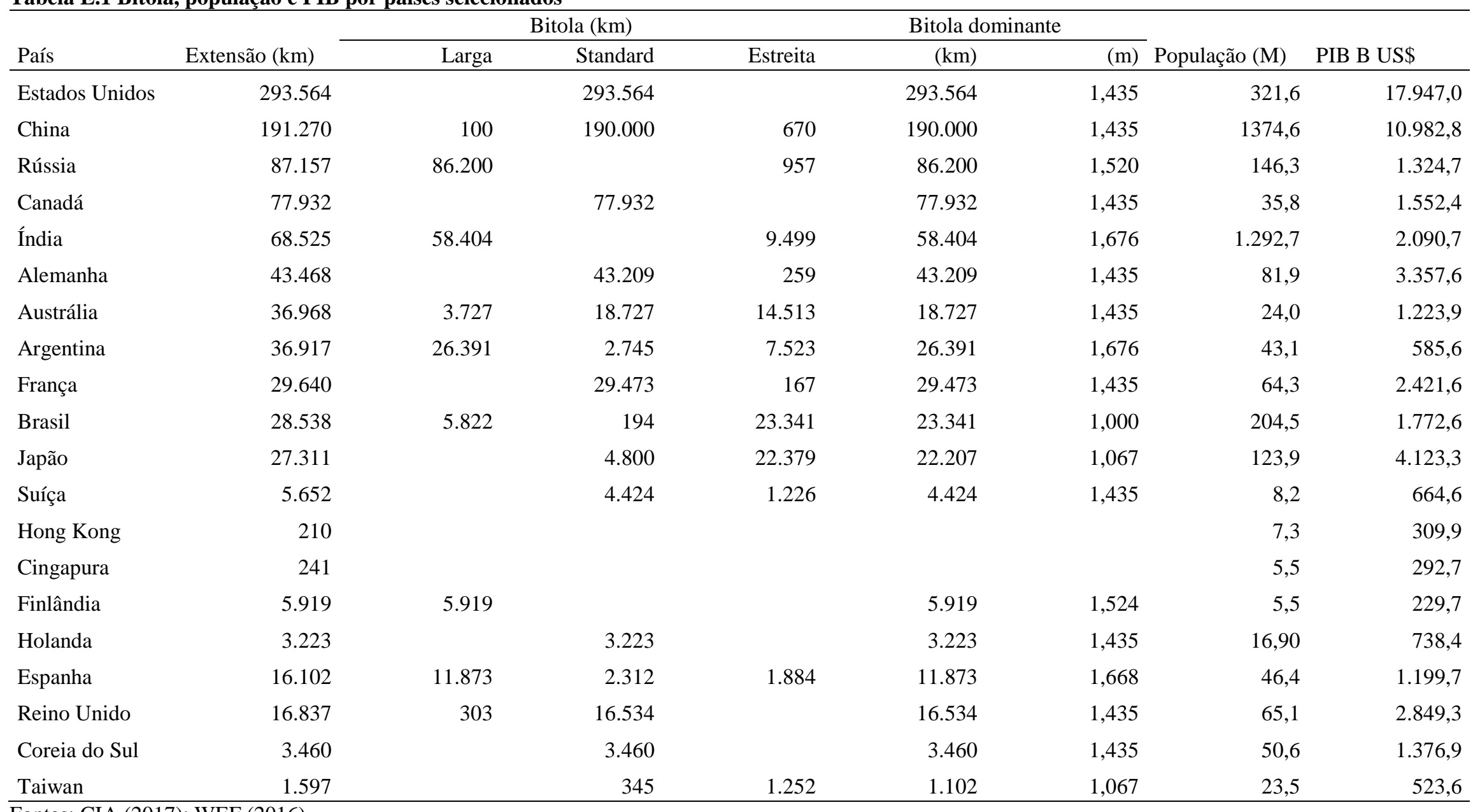

